\title{
Computer-based diabetes self-management interventions for adults with type 2 diabetes mellitus (Review)
}

Pal K, Eastwood SV, Michie S, Farmer AJ, Barnard ML, Peacock R, Wood B, Inniss JD, Murray E

Pal K, Eastwood SV, Michie S, Farmer AJ, Barnard ML, Peacock R, Wood B, Inniss JD, Murray E.

Computer-based diabetes self-management interventions for adults with type 2 diabetes mellitus.

Cochrane Database of Systematic Reviews 2013, Issue 3. Art. No.: CD008776.

DOI: 10.1002/14651858.CD008776.pub2.

www.cochranelibrary.com 
TABLE OF CONTENTS

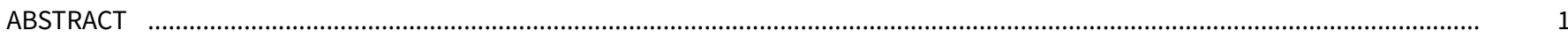

PLAIN LANGUAGE SUMMARY

SUMMARY OF FINDINGS

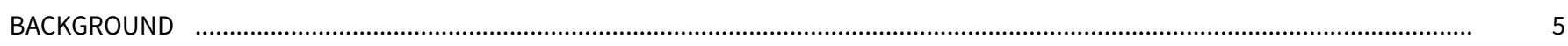

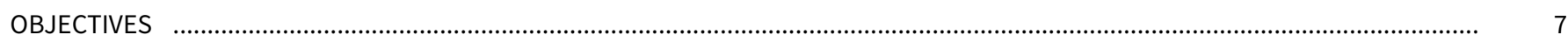

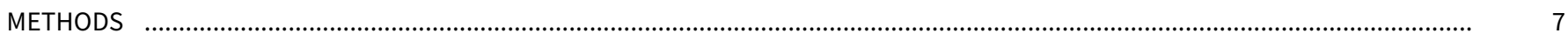

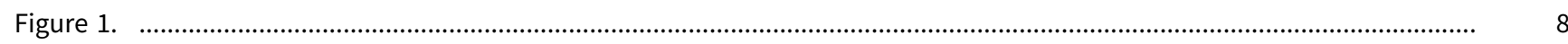

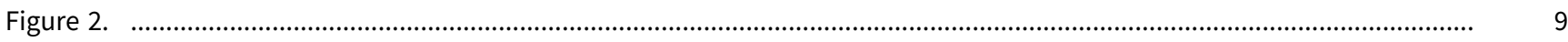

Figure 3.

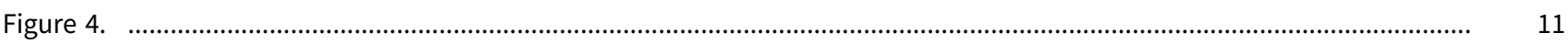

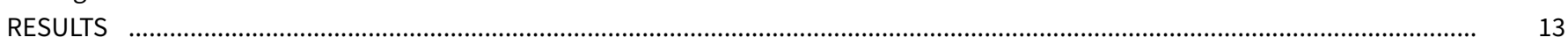

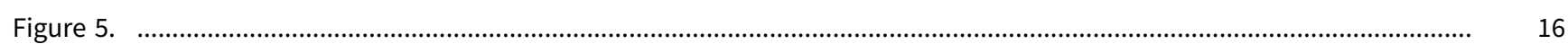

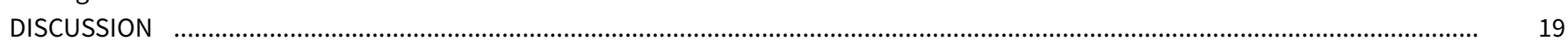

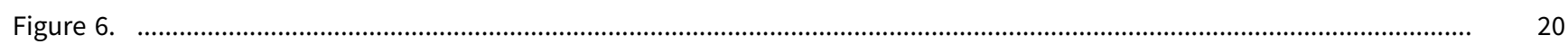

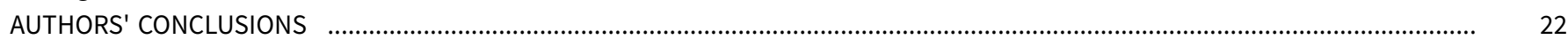

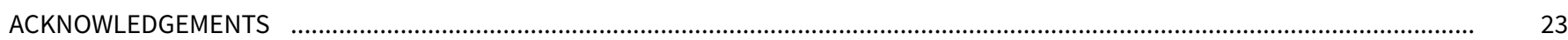

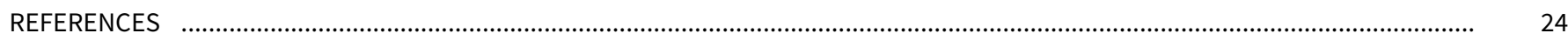

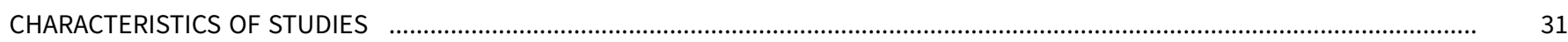

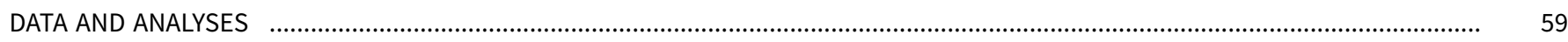

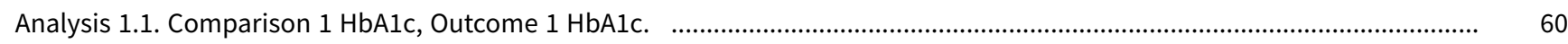

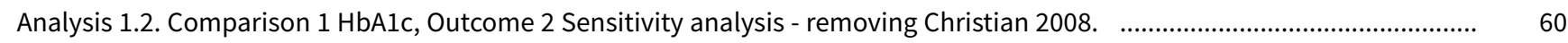

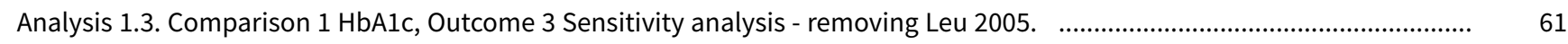

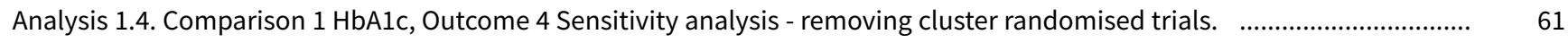

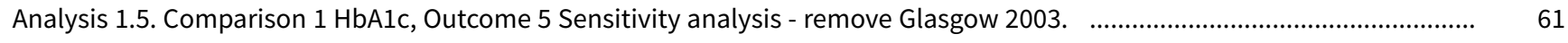

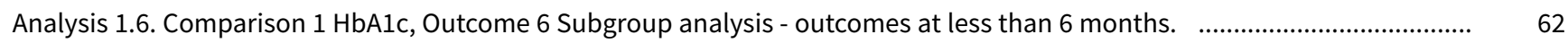

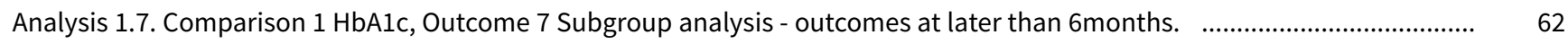

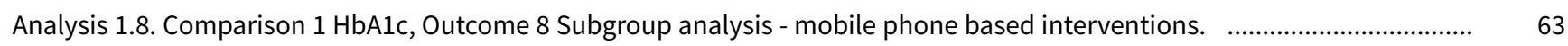

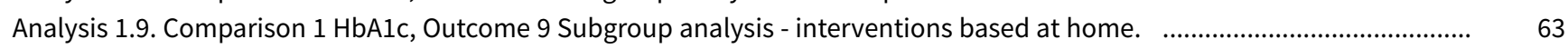

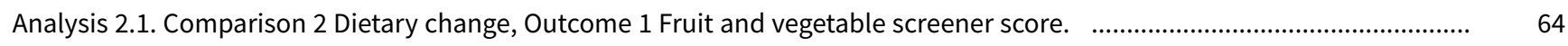

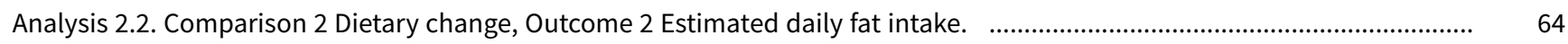

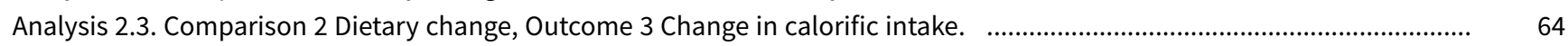

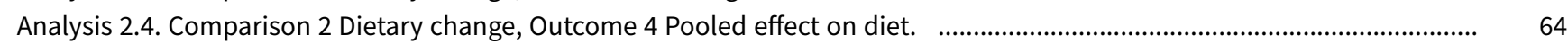

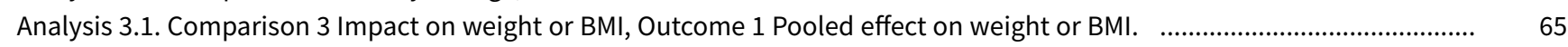

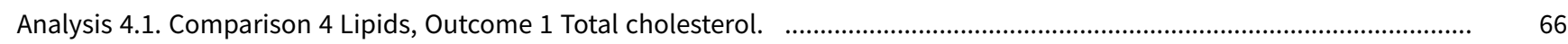

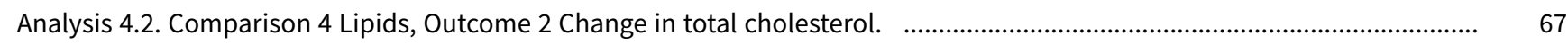

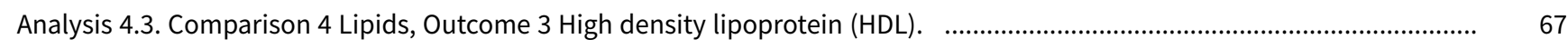

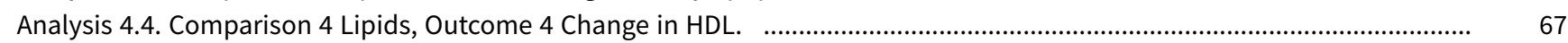

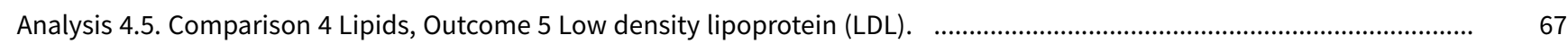

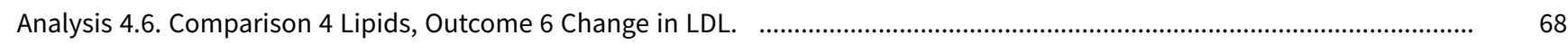

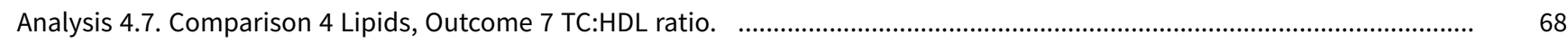

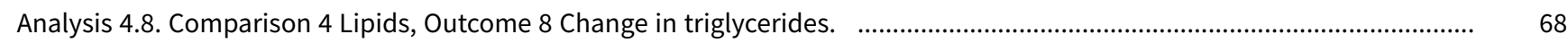

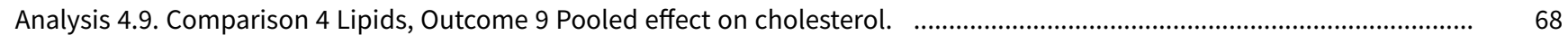

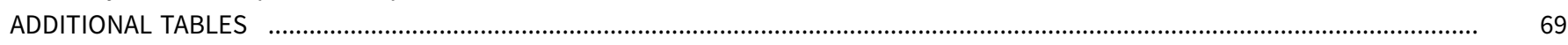

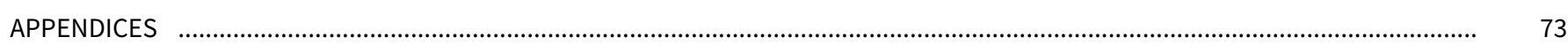

CONTRIBUTIONS OF AUTHORS

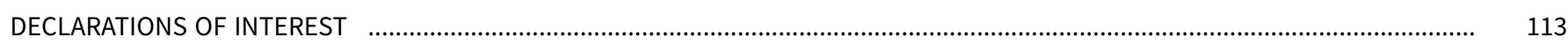

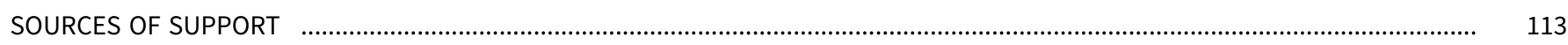

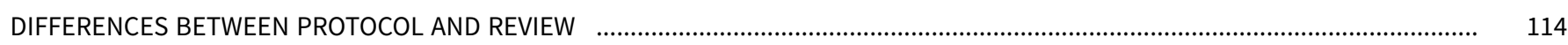

INDEX TERMS 
[Intervention Review]

\section{Computer-based diabetes self-management interventions for adults with type 2 diabetes mellitus}

Kingshuk Pal ${ }^{1}$, Sophie V Eastwood ${ }^{1}$, Susan Michie ${ }^{1}$, Andrew J Farmer², Maria L Barnard ${ }^{3}$, Richard Peacock ${ }^{4}$, Bindie Wood ${ }^{1}$, Joni D Inniss ${ }^{1}$, Elizabeth Murray ${ }^{1}$

${ }^{1}$ Research Department of Primary Care and Population Health, University College London, London, UK. 2Department of Primary Care Health Sciences, University of Oxford, Oxford, UK. ${ }^{3}$ Department of Diabetes, The Whittington Hospital NHS Trust, London, UK. ${ }^{4}$ Archway Healthcare Library, London, UK

Contact: Kingshuk Pal, Research Department of Primary Care and Population Health, University College London, Upper Floor 3, Royal Free Hospital, Rowland Hill Street, London, NW3 PF, UK. k.pal@ucl.ac.uk, drkpal@gmail.com.

Editorial group: Cochrane Metabolic and Endocrine Disorders Group.

Publication status and date: New, published in Issue 3, 2013.

Citation: Pal K, Eastwood SV, Michie S, Farmer AJ, Barnard ML, Peacock R, Wood B, Inniss JD, Murray E. Computer-based diabetes selfmanagement interventions for adults with type 2 diabetes mellitus. Cochrane Database of Systematic Reviews 2013, Issue 3. Art. No.: CD008776. DOI: 10.1002/14651858.CD008776.pub2.

Copyright ( 2013 The Cochrane Collaboration. Published by John Wiley \& Sons, Ltd.

\section{A B S T R A C T}

\section{Background}

Diabetes is one of the commonest chronic medical conditions, affecting around 347 million adults worldwide. Structured patient education programmes reduce the risk of diabetes-related complications four-fold. Internet-based self-management programmes have been shown to be effective for a number of long-term conditions, but it is unclear what are the essential or effective components of such programmes. If computer-based self-management interventions improve outcomes in type 2 diabetes, they could potentially provide a cost-effective option for reducing the burdens placed on patients and healthcare systems by this long-term condition.

\section{Objectives}

To assess the effects on health status and health-related quality of life of computer-based diabetes self-management interventions for adults with type 2 diabetes mellitus.

\section{Search methods}

We searched six electronic bibliographic databases for published articles and conference proceedings and three online databases for theses (all up to November 2011). Reference lists of relevant reports and reviews were also screened.

\section{Selection criteria}

Randomised controlled trials of computer-based self-management interventions for adults with type 2 diabetes, i.e. computer-based software applications that respond to user input and aim to generate tailored content to improve one or more self-management domains through feedback, tailored advice, reinforcement and rewards, patient decision support, goal setting or reminders.

\section{Data collection and analysis}

Two review authors independently screened the abstracts and extracted data. A taxonomy for behaviour change techniques was used to describe the active ingredients of the intervention.

\section{Main results}

We identified 16 randomised controlled trials with 3578 participants that fitted our inclusion criteria. These studies included a wide spectrum of interventions covering clinic-based brief interventions, Internet-based interventions that could be used from home and mobile 
phone-based interventions. The mean age of participants was between 46 to 67 years old and mean time since diagnosis was 6 to 13 years. The duration of the interventions varied between 1 to 12 months. There were three reported deaths out of 3578 participants.

Computer-based diabetes self-management interventions currently have limited effectiveness. They appear to have small benefits on glycaemic control (pooled effect on glycosylated haemoglobin A1c (HbA1c): $-2.3 \mathrm{mmol} / \mathrm{mol}$ or $-0.2 \%$ ( $95 \%$ confidence interval (Cl) -0.4 to $-0.1 ; \mathrm{P}=0.009 ; 2637$ participants; 11 trials). The effect size on HbAlc was larger in the mobile phone subgroup (subgroup analysis: mean difference in $\mathrm{HbA} 1 \mathrm{c}-5.5 \mathrm{mmol} / \mathrm{mol}$ or $-0.5 \%(95 \% \mathrm{Cl}-0.7$ to -0.3$) ; \mathrm{P}<0.00001 ; 280$ participants; three trials). Current interventions do not show adequate evidence for improving depression, health-related quality of life or weight. Four (out of 10) interventions showed beneficial effects on lipid profile.

One participant withdrew because of anxiety but there were no other documented adverse effects. Two studies provided limited costeffectiveness data - with one study suggesting costs per patient of less than $\$ 140$ (in 1997) or 105 EURO and another study showed no change in health behaviour and resource utilisation.

\section{Authors' conclusions}

Computer-based diabetes self-management interventions to manage type 2 diabetes appear to have a small beneficial effect on blood glucose control and the effect was larger in the mobile phone subgroup. There is no evidence to show benefits in other biological outcomes or any cognitive, behavioural or emotional outcomes.

\section{PLAIN LANGUAGE SUMMARY}

\section{Using computers to self-manage type 2 diabetes}

Diabetes is one of the commonest long-term medical conditions, affecting around 347 million adults worldwide. Around $90 \%$ of them have type 2 diabetes and are at significant risk of developing diabetes related complications such as strokes or heart attacks. Patient education programmes can reduce the risk of diabetes-related complications, but many people with type 2 diabetes have never attended structured education programmes to learn how to look after themselves (self-management). Better use of computers might be one way of helping more people learn about self-management.

We identified 16 trials involving 3578 adults that met our criteria. These studies included different types of interventions used in different places like touch screen computers in hospital clinics, computers connected to the Internet at home and programmes that communicated with mobile phones. The average age of people taking part was between 46 to 67 years old and most of those people had lived with diabetes for 6 to 13 years. Participants were given access to the interventions for 1 to 12 months, depending on the intervention. Three out of the 3578 participants died but these deaths did not appear to be linked to the trials.

Overall, there is evidence that computer programmes have a small beneficial effect on blood sugar control - the estimated improvement in glycosylated haemoglobin A1c ( $\mathrm{HbA1c}$ - a long-term measurement of metabolic control) was $2.3 \mathrm{mmol} / \mathrm{mol}$ or $0.2 \%$. This was slightly higher when we looked at studies that used mobile phones to deliver their intervention - the estimated improvement in HbA1c was 5.5 $\mathrm{mmol} / \mathrm{mol}$ or $0.5 \%$ in the studies that used mobile phones. Some of the programmes lowered cholesterol slightly. None of the programmes helped with weight loss or coping with depression.

One participant withdrew because of anxiety but there were no obvious side effects and hypoglycaemic episodes were not reported in any of the studies. There was very little information about costs or value for money.

In summary, existing computer programmes to help adults self-manage type 2 diabetes appear to have a small positive effect on blood sugar control and the mobile phone interventions appeared to have larger effects. There is no evidence to show that current programmes can help with weight loss, depression or improving health-related quality of life but they do appear to be safe. 


\section{SUMMARY OF FINDINGS}

\section{Summary of findings for the main comparison.}

\section{Computer-based diabetes self-management interventions for adults with type 2 diabetes mellitus}

Patient or population: participants with type 2 diabetes mellitus

Interventions settings: clinic-based (touch screen or other clinic computer), home computer-based and mobile phone-based interventions

Intervention: computer-based software applications that respond to user input and aim to generate tailored content to improve one or more of the cognitive, behaviour and skills and emotional self-management domains through feedback, tailored advice, reinforcement and rewards, patient decision support, goal setting or reminders

Comparison: standard diabetes care, non-interactive computer-based programmes, paper educational material, delayed start/waiting list, face-to-face diabetes self-management education

\begin{tabular}{|c|c|c|c|c|}
\hline Outcomes & $\begin{array}{l}\text { Relative effect } \\
(95 \% \mathrm{Cl})\end{array}$ & $\begin{array}{l}\text { No of partici- } \\
\text { pants } \\
\text { (studies) }\end{array}$ & $\begin{array}{l}\text { Quality of the } \\
\text { evidence } \\
\text { (GRADE) }\end{array}$ & Comments \\
\hline $\begin{array}{l}\text { Health-related } \\
\text { quality of life } \\
\text { [follow-up: } 2 \text { to } 18 \\
\text { months] }\end{array}$ & See comment & 2113 & $\begin{array}{l}\oplus \oplus \oplus \ominus \\
\text { moderate } a\end{array}$ & $\begin{array}{l}\text { No study showed statistically significant differ- } \\
\text { ences between intervention and control groups. }\end{array}$ \\
\hline $\begin{array}{l}\text { Death from any } \\
\text { cause } \\
\text { [follow-up: } 2 \text { to } 18 \\
\text { months] }\end{array}$ & See comment & $\begin{array}{l}3578 \\
(16)\end{array}$ & $\begin{array}{l}\oplus \oplus \oplus \oplus \\
\text { high }\end{array}$ & $\begin{array}{l}\text { A total of three deaths in the } 16 \text { studies. Two par- } \\
\text { ticipants died in one study (Lorig 2010) and one } \\
\text { participant died in another study from complica- } \\
\text { tions of a cerebrovascular attack (Leu 2005). No } \\
\text { further details were provided in the study reports. }\end{array}$ \\
\hline $\begin{array}{l}\text { Depression } \\
\text { [follow-up: } 2 \text { to } 18 \\
\text { months] }\end{array}$ & See comment & $\begin{array}{l}2273 \\
(6)\end{array}$ & $\begin{array}{l}\oplus \oplus \oplus \ominus \\
\text { moderateb }\end{array}$ & $\begin{array}{l}\text { No study showed statistically significant differ- } \\
\text { ences in depression scores or incidence of depres- } \\
\text { sion between intervention and control groups. }\end{array}$ \\
\hline $\begin{array}{l}\text { Adverse effects } \\
\text { [follow-up: } 2 \text { to } 12 \\
\text { months] }\end{array}$ & See comment & $\begin{array}{l}3578 \\
(16)\end{array}$ & $\begin{array}{l}\oplus \oplus \oplus \oplus \\
\text { high }\end{array}$ & $\begin{array}{l}\text { One study reported a participant withdrawing } \\
\text { due to anxiety related to the study. }\end{array}$ \\
\hline $\begin{array}{l}\text { HbA1c [\%] } \\
\text { [follow-up: } \\
\text { 1. } 2 \text { to } 12 \text { months } \\
\text { 2. } 3 \text { to } 12 \text { months] }\end{array}$ & $\begin{array}{l}\text { 1. }-0.2(-0.4 \text { to } \\
-0.1) \\
\text { 2. }-0.5(-0.7 \text { to } \\
-0.3)\end{array}$ & $\begin{array}{l}\text { 1. } 2673 \\
\text { (11) } \\
\text { 2. } 280 \\
\text { (3) }\end{array}$ & $\begin{array}{l}\text { 1. } \oplus \oplus \oplus \ominus \\
\text { moderatec } \\
\text { 2. } \oplus \oplus \ominus \ominus \\
\text { lowd }\end{array}$ & $\begin{array}{l}\text { 1. Computer-based interventions resulted in } \\
\text { a } 0.2 \% \text { greater } \mathrm{HbA} 1 \mathrm{c} \text { reduction than control } \\
\text { groups (difference in change and final values). } \\
\text { 2. Subgroup mobile phone interventions result- } \\
\text { ed in a } 0.5 \% \text { greater } \mathrm{HbA1c} \text { reduction than control } \\
\text { groups (difference in final values). }\end{array}$ \\
\hline $\begin{array}{l}\text { Economic data } \\
\text { [follow-up: } 18 \\
\text { months] }\end{array}$ & See comment & $\begin{array}{l}761 \\
(1)\end{array}$ & $\begin{array}{l}\oplus \oplus \odot \ominus \\
\text { lowe }\end{array}$ & $\begin{array}{l}\text { One study looked at health behaviour and re- } \\
\text { source utilisation but found no significant differ- } \\
\text { ences between intervention or control groups. }\end{array}$ \\
\hline
\end{tabular}

GRADE Working Group grades of evidence

High quality: Further research is very unlikely to change our confidence in the estimate of effect.

Moderate quality: Further research is likely to have an important impact on our confidence in the estimate of effect and may change the estimate. 
Low quality: Further research is very likely to have an important impact on our confidence in the estimate of effect and is likely to change the estimate.

Very low quality: We are very uncertain about the estimate.

aSerious risk of bias

bSerious risk of bias

CInconsistency, indirectness

dSubgroup analysis, low number of participants, indirectness

eOne study only, serious risk of bias 


\section{B A C K G R O U N D}

The burden of diabetes is growing with 347 million people currently affected worldwide (Danaei 2011) and numbers projected to increase to 552 million by 2030 (International Diabetes Federation 2011). In the UK, the cost to the National health Service (NHS) related to diabetes in 2002 was estimated to be around " $£ 1.3$ billion a year, with most of this cost arising from the long-term complications resulting from diabetes not being managed properly" (Wanless 2002), while the International Diabetes Federation (IDF) suggests that in the developed world the cost of caring for patients with diabetes is double that of the background population. Complications of diabetes range from an increased risk of heart attacks, strokes and amputations to blindness and kidney damage: a 60-year old male newly diagnosed with type 2 diabetes (without pre-existing cardiovascular disease) can expect to lose 8 to 10 years of life if his diabetes is poorly controlled (National Collaborating Centre 2008). The need for cost-effective improvements in managing diabetes is evidently important.

Improving blood sugar control in patients with diabetes can reduce the risk of death and microvascular complications (DCCT 1993; UKPDS 1998); however, achieving significant reductions in blood glucose levels can be difficult in practice (Peters 1996; Saaddine 2002). Cardiovascular risk factors such as raised blood pressure and lipids are also important and targeting these individually or together can be effective in reducing mortality (Gaede 2003). There is a growing body of evidence that supports the notion that improving self-care improves the biological complications of diabetes, as well as cognitive and emotional outcomes (Campbell 2003).

\section{Diabetes and self-management}

Corbin and Strauss (Corbin 1988) described three distinct elements of coping with a chronic illness.

1. Medical and behavioural management: e.g. taking medication, attending follow-up.

2. Role management: e.g. taking on the 'patient' role, the effect on relationships.

3. Emotional management: dealing with the fear, anger, guilt etc. that often accompany living with a chronic illness.

Lorig and Holman used the work of Corbin and Strauss as a basis to describe six skills required for self-management (Lorig 2003): 1) problem solving, 2) decision making, 3) resource utilisation, 4) the formation of a patient-provider partnership, 5) action planning and behaviour change, and 6) patients tailoring management plans to suit their needs.

These skills describe the medical, behavioural and rolemanagement elements of self-management, but the ability to cope with the emotional burden associated with the illness is also needed. Diabetes self-management education (DSME) is a formal term used to describe the ongoing process of facilitating the knowledge, skill and abilities necessary for diabetes self-care (Funnell 2009), and new technology has the potential to improve patient outcomes by helping patients improve their abilities in all of these domains.

\section{The evidence for diabetes self-management education}

A number of existing evidence-based programmes to improve selfcare are already widely used and examples of these diabetes self-management education programmes include: the diabetes education and self-management for ongoing and newly diagnosed (DESMOND) programme for people with newly diagnosed type 2 diabetes (Davies 2008), the 'Rethink Organization to iMprove Education and Outcomes' (ROMEO) for people with type 2 diabetes (Trento 2010), the 'Diabetes X-PERT Programme' (Deakin 2006) for people with type 2 diabetes and the dose adjustment for normal eating (DAFNE) for people with type 1 diabetes (DAFNE 2002). Examples of general patient self-management programmes include the chronic disease self-management programme (CDSMP) (Lorig 2001) and the expert patient programme (EPP) (Department of Health 2001; Kennedy 2007). Group-based training for selfmanagement in people with type 2 diabetes appears to improve diabetes control (glycated haemoglobin reduced by $1.4 \%$ at six months) and knowledge of diabetes in the short- and longerterm with weaker evidence to show effects on blood pressure, weight and health-related quality of life (Deakin 2005). In contrast, there does not currently appear to be much evidence to show that individual patient education significantly improves glycaemic control, body mass index or blood pressure (Duke 2009).

\section{The potential for new technology}

New technology offers some exciting new opportunities to expand on the success above and counter some of the difficulties (Griffiths 2006; Tate 2004). Desktop, laptop or handheld computers and mobile phones have the processing power and connectivity to allow remote access to information and algorithms that may be able to target most of the components of existing face-to-face DSME programmes. They also have the potential to be relatively cheap, easily distributable, delivered at multiple locations (clinical, community-based, at home or on the move) at times convenient for patients, offer patients as many interventions as they need or want and offer continuing support, send out automatic reminders and present information in an attractive, tailored format to suit patients' needs. Connectivity mentioned above also allows easy formation of social networking and peer support groups beyond traditional clinical settings. Diabetes self-management interventions often show evidence of short-term benefits that may fade over time (Minet 2010). Computer-based interventions have the potential to provide ongoing self-management support to reenforce the benefits over time.

\section{Description of the condition}

Diabetes mellitus is a metabolic disorder resulting from a defect in insulin secretion, insulin action, or both. A consequence of this is chronic hyperglycaemia (that is elevated levels of plasma glucose) with disturbances of carbohydrate, fat and protein metabolism. Long-term complications of diabetes mellitus include retinopathy, nephropathy and neuropathy. The risk of cardiovascular disease is increased. For a detailed overview of diabetes mellitus, please see under 'Additional information' in the information on the Metabolic and Endocrine Disorders Group in The Cochrane Library (see 'About', 'Cochrane Review Groups (CRGs)'). For an explanation of methodological terms, see the main glossary in The Cochrane Library. 


\section{Description of the intervention}

The term computer-based diabetes self-management intervention includes any application that takes input from a patient and uses communication or processing technology to provide a tailored response that facilitates one or more aspect of diabetes selfmanagement, i.e. technology that promotes 1) problem solving,

2) decision making, 3) resource utilisation, 4) the formation of a patient-provider partnership, 5) action planning, emotional management or behaviour change or 6) self-tailoring, without needing continuous professional input.

\section{Adverse effects of the intervention}

Although difficulties with the uptake and reach of such interventions have been documented in the literature (Glasgow 2010a), there is currently no good evidence documenting adverse effects of these interventions. Possible adverse effects could include the following.

- Patients receiving incorrect advice or misinterpreting selfmanagement guidance.

- Patients making decisions that clinicians would deem 'inappropriate'.

- Frustration at absence of services the intervention suggests would be useful.

- Sense of failure, loss of self-esteem or self-worth amongst patients who stop using it or do not find it helpful.

- Exclusion arising from digital divide or inability to use technology.

- Risk of health service system only providing e-health intervention, leaving those unable to use such interventions unserved. Breakdown or strain on existing doctor-patient relationships if there is a difference in advice from the intervention and healthcare providers.

- Clinician information overload from data generated by selfmanagement recording.

- Increased use and strain on health services from more engaged patients.

\section{How the intervention might work}

Computer-based interventions to improve diabetes self-care are complex interventions (Medical Research Council 2008), and they can be judged on their ability to improve biological, cognitive, behavioural and emotional outcomes. For this to happen, interventions need to help patients improve their knowledge and understanding of diabetes and change their patterns of eating, physical activity and adherence to treatment regimens. The theory behind the educational component of interventions can be based on principles of adult learning and education (Collins 2004) although the theoretical basis of diabetes educational interventions is often poorly described (Brown 1999). Knowledge and understanding are thought to be important cognitions that can influence health behaviour and they are components of some of the theories mentioned below.

There are currently a number of different theories that are used to model health behaviour which often overlap and may use different terms to describe similar concepts (Noar 2005). Some of the most commonly cited models for health behaviour focus on cognitive constructs such as attitudes, beliefs and expectations (related to outcomes, self-belief or what other people might think) and examples of such models include the 'Health Belief Model' (Rosenstock 1966), 'Theory of Reasoned Action and Planned Behaviour' (Ajzen 2001), 'Social Cognitive Theory' (Bandura 1986) and 'Protection Motivation Theory' (Rogers 1975). Using these theories as a basis for designing selfmanagement programmes has a number of challenges: 1 ) the theories focus on predicting behaviour and were not primarily created as theories for enabling behaviour change; 2) they only partially explain the observed variance seen in behavioural outcomes; 3 ) they are heavily focused on motivated or intentional behaviour while the behaviours that need to be changed to improve health are often automatic, habitual patterns of behaviour; and 4) they do not model multiple behaviour change (Munro 2007).

An intervention based on theory is more likely to be effective than one not based on theory (Noar 2008), and also has the advantages of a generalisable framework, the possibility of understanding why the interventions might work, and facilitating the accumulation of knowledge (Michie 2008). However, there is no clear consensus on how to choose one or more theories of health behaviour in order to create an intervention. One approach is to assess the behaviours that need to be changed in terms of theoretical domains explaining why current behaviours exist. Using a mapping framework (Michie 2008), these domains can then be used to select appropriate behaviour change techniques (examples shown in Table 1). The use of integrative theoretical domains allows a comprehensive theoretical assessment rather than starting by applying only one or two theories and potentially missing important explanations. Part of the aim of this review is to describe the interventions in terms of behaviour change techniques and theories (as well as mode of delivery or technology used) thereby allowing a theory-based rationale for grouping or combining intervention components.

\section{Why it is important to do this review}

There is evidence that low-intensity brief interventions for simple behaviour change (e.g. smoking cessation) are effective even when delivered by computer-based applications (Portnoy 2008), while higher-intensity face-to-face interventions (group or one-to-one) set the current standard for self-management training. The fundamental question is whether there is a costeffective niche for computer-based 'intermediate' interventions (i.e. interventions that are more costly and time consuming than the brief intervention model but cheaper to implement than faceto-face contact) for the more complex (multiple) behaviour change required in chronic disease self-management, in this particular case, type 2 diabetes mellitus.

There are some important questions about computer-based interventions for diabetes self-management that need answering and have not been fully answered by previous reviews in the area as there has been insufficient evidence in the past.

1. Unknown efficacy - do they really work?

2. Uncertainty about active components - how do they work?

3. What is the clinical significance of any reported benefits of these interventions?

4. Are they cost effective?

5. What harm can come from computer-based interventions?

6. Which populations and sub-populations do they benefit? 


\section{O B JECTIVES}

To assess the effects on health status and health-related quality of life of computer-based diabetes self-management interventions for adults with type 2 diabetes mellitus.

\section{METHODS}

\section{Criteria for considering studies for this review}

\section{Types of studies}

Randomised controlled clinical trials.

\section{Types of participants}

Adult patients with type 2 diabetes mellitus. Adult patients were defined as patients aged 18 and over.

\section{Diagnostic criteria}

To be consistent with changes in classification and diagnostic criteria of diabetes mellitus through the years, the diagnosis should have been established using the standard criteria valid at the time of the beginning of the trial (for example ADA 1999; ADA 2008; WHO 1998). Ideally, diagnostic criteria should have been described. Where necessary, authors' definition of diabetes mellitus were used.

\section{Types of interventions}

\section{Intervention}

Computer-based software applications that respond to user input and aim to generate tailored content to improve one or more of the following self-management domains through feedback, tailored advice, reinforcement and rewards, patient decision support, goal setting or reminders.

\section{Cognitive}

- Knowledge about the diabetes disease process, complications and treatment options.

- Goal setting to promote health.

- Self-efficacy and confidence in own ability to manage diabetes.

\section{Behaviour and skills}

- Incorporating appropriate nutritional management.

- Incorporating physical activity into lifestyle.

- Utilising medications (if applicable) for therapeutic effectiveness.

- Monitoring blood glucose, urine ketones (when appropriate), and using the results to improve control.

- Accessing services and preventing, detecting and treating acute complications.

- Preventing (through risk reduction behaviour), detecting, and treating chronic complications.

\section{Emotional}

- Integrating psychosocial adjustment to daily life.

- Managing anxiety, depression and stress.

- Providing social support for patients.

\section{Control}

- Standard diabetes care.

- Non-interactive computer-based programme.

- Paper educational material.

- Delayed start/waiting list.

- Face-to-face diabetes self-management education.

There is no equivalent of a placebo-controlled trial as all of the controls have patients with a chronic illness who will have ongoing clinical input that could have an effect on the target population. Some would argue that any effect of standard care is desirable as it counteracts the effect of the selection bias inherent in choosing volunteers for trials who are more likely to be motivated and concerned about their health and it provides a more realistic estimate of any advantage of the treatment over existing clinical care. However, in the case of behavioural interventions, 'standard care' may involve a number of the behavioural techniques that are being tested and their presence in the control group could make the results difficult to interpret. We have therefore tried to analyse any 'standard care' provided to comparison groups and implicit intervention or technique that might be part of the comparison group (de Bruin 2009).

\section{Setting}

There were no restrictions based on setting or technology used to deliver the intervention.

\section{Exclusions}

Any program, website or application.

- Targeted only at patients with type 1 diabetes

- Involving participants aged under the age of 18 (including studies on mixed populations of adults and children)

- Used only for communication between patients and professionals

- Targeted exclusively at health professionals

Studies carried out on mixed populations of patients with type 1 and type 2 diabetes were included in the review as long as more than $50 \%$ of the patients had type 2 diabetes. Where possible, data for patients with type 2 diabetes were extracted and the data for patients with type 1 diabetes discarded. When that was not possible, data for the mixed population were used. Four studies included in the review had mixed populations (Leu 2005; Lo 1996; Smith 2000; Wise 1986). One of these studies (Leu 2005) provided sufficient data to include it in the meta-analysis. A subgroup analysis was undertaken to examine the impact of removing studies on mixed populations.

\section{Types of outcome measures}

Integrating all the factors contributing to diabetes selfmanagement into a unified model to describe how they might affect outcomes is challenging. A deliberately simplified schematic that could aid this process is shown in Figure 1 . As many of the health outcomes take many years to develop, it is not practical to use them as primary outcome measures for this review as follow-up in the studies would not be long enough to demonstrate differences in these. However, more proximal variables such as glycosylated haemoglobin Alc ( $\mathrm{HbAlc}$, representing an average measure of 
blood sugars), body mass index (BMI), depression or anxiety may show changes over suitable time scales.

Figure 1. A model to demonstrate how self-management interventions might affect outcomes in type 2 diabetes

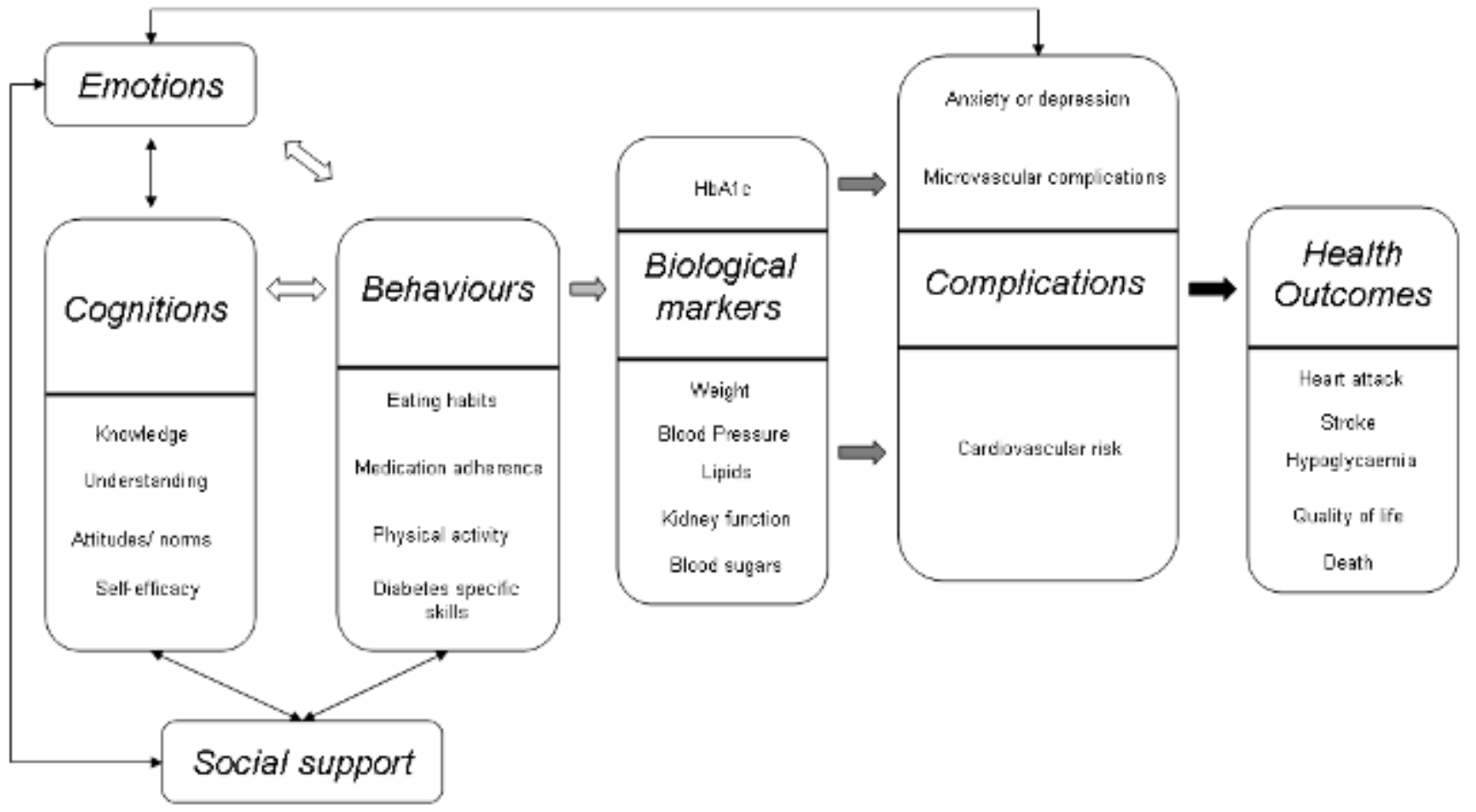

\section{Primary outcomes}

- Health-related quality of life

- Death from any cause

- HbAlc

\section{Secondary outcomes}

Cognitions

- Change in knowledge and understanding

- Self-efficacy

Behaviours

- Physical activity

Social support

- Change in social support

\section{Biological markers}

- Cardiovascular risk factors, which include blood pressure, BMI and lipids

\section{Complications}

- Hospital admissions or emergency unit attendances

- Anxiety or depression

Other outcomes

- Hypoglycaemia

- Adverse effects
- Cost-effectiveness and economic data

Covariates, effect modifiers and confounders

- Age

- Gender

- Computer literacy

- Attrition

\section{Timing of outcome measurement}

At the end of the intervention and for as long as follow-up was carried out. We defined short-term follow-up as that measured within 30 days of the end of the intervention period to measure the immediate effects of the intervention; medium-term follow-up as between one to six months after the intervention to see if the effects continue; long-term follow-up data as six months and later from the end of the intervention to see how effects change over time. For the overall meta-analysis the data at the longest follow-up date available were used.

\section{Search methods for identification of studies}

\section{Electronic searches}

We used the following sources for the identification of trials.

- The Cochrane Library (2011, issue 10).

- MEDLINE (from inception until week 1 November 2011).

- EMBASE (from inception until 14/11/2011).

- PsycINFO (from inception until week 2 November 2011) (for studies and dissertation abstracts). 
- Web of Science (from inception until 14/11/2011) (for studies and conference proceedings).

- CINAHL (from inception until 17/11/2011).

For detailed search strategies please see under Appendix 1.

Studies published in any language were included and the final included studies were published in English (15) and Chinese (1).

\section{Searching other resources}

We screened reference lists from relevant published studies and contacted authors for further information when required.

We used the following resources to search for unpublished literature.
- ASLIB Index to Theses.

- Australasian Digital Theses programme.

- UMI ProQuest Digital Dissertations and Theses.

\section{Data collection and analysis}

\section{Selection of studies}

To determine the studies to be assessed further, two review authors (KP, SE) independently scanned the abstract, title or both sections of every record retrieved. All potentially relevant articles were investigated as full text. Where differences in opinion existed, they were resolved by a third party (EM) and the rationale justified in a steering group meeting. An adapted PRISMA (Preferred Reporting Items for Systematic reviews and Meta-Analyses) flow-chart of study selection (Figure 2) has been attached (Liberati 2009).

Figure 2. Study flow diagram.

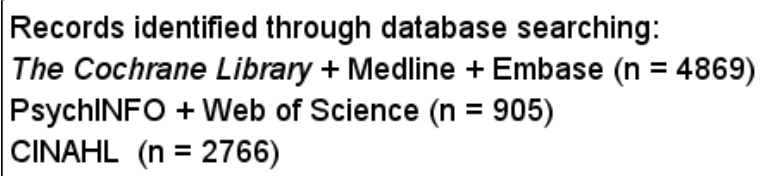

Records identified through other sources:

ASLIB Index to Theses $(n=44)$

Australasian Digital Theses programme $(n=28)$

UMI ProQuest Digital Dissertations and $(n=121)$

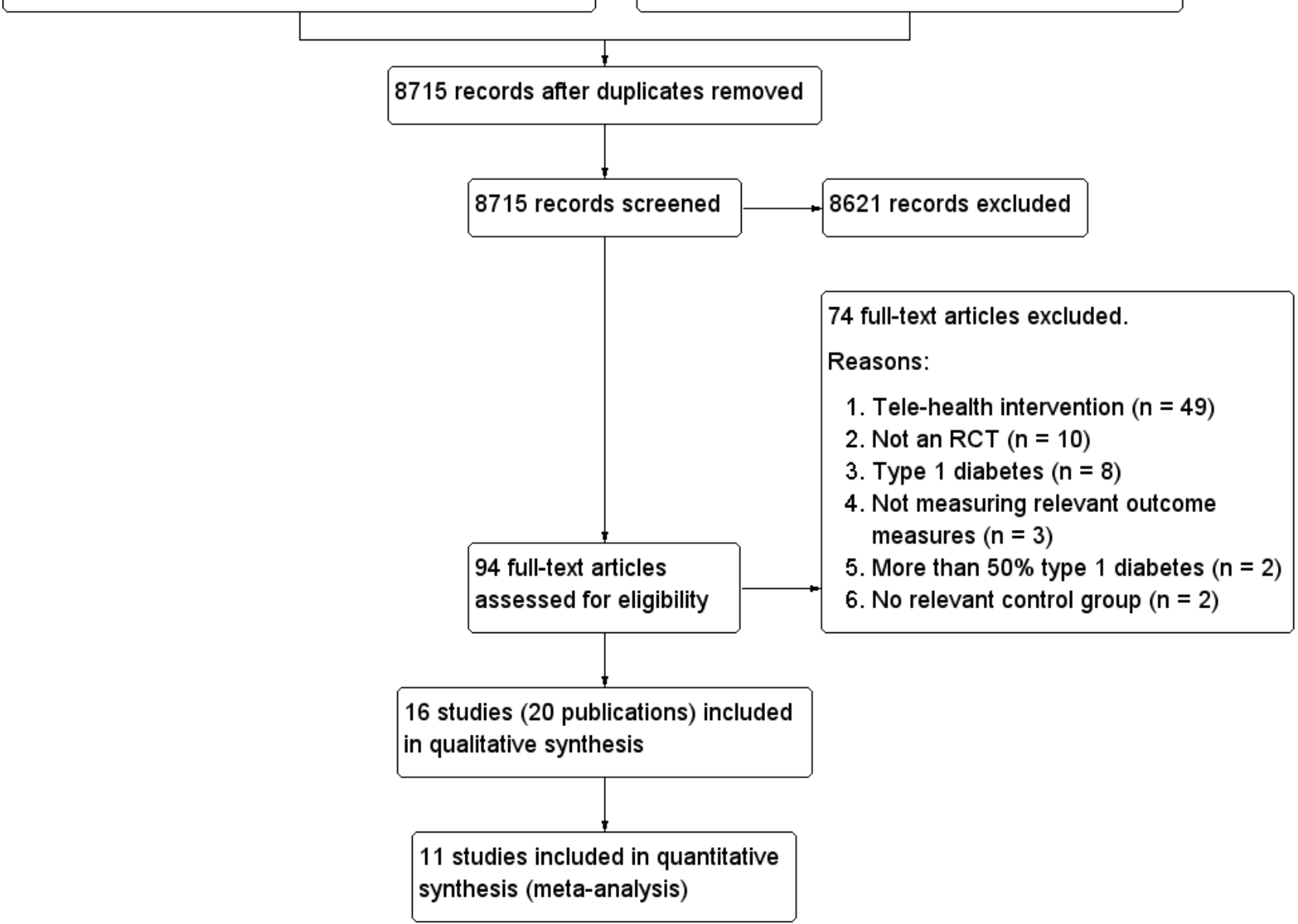

\section{Data extraction and management}

For studies that fulfilled inclusion criteria, two review authors (KP, $\mathrm{SE}$ ) independently extracted relevant population and intervention characteristics using standard data extraction templates (for details see 'Characteristics of included studies' and Table 2; Appendix
2; Appendix 3; Appendix 4; Appendix 5; Appendix 6; Appendix 7; Appendix 8; Appendix 9; Appendix 10; Appendix 11) with any disagreements resolved by discussion, or if required by a third party (EM). Any relevant missing information on the trial was sought from the original author(s) of the article, when required. 


\section{Dealing with duplicate publications}

In the case of duplicate publications and companion papers of a primary study, we tried to maximise yield of information by simultaneous evaluation of all available data. In cases of doubt, the original publication (usually the oldest version) obtained priority.

\section{Assessment of risk of bias in included studies}

Two review authors (KP, SE) assessed each trial independently. Possible disagreements were resolved by consensus, or with consultation of a third party (E.M.) and discussed in a steering group meeting where the final decision was made.

Risk of bias was assessed using the Cochrane Collaboration's tool (Higgins 2011). The following criteria were used.
- Was the allocation sequence adequately generated?

- Was the allocation adequately concealed?

- Was knowledge of the allocated intervention adequately prevented during the study?

- Were incomplete outcome data adequately addressed?

- Are reports of the study free of suggestion of selective outcome reporting?

- Was the study apparently free of other problems that could put it at a high risk of bias?

We judged risk of bias criteria as 'low risk', 'high risk' or 'unclear risk' and evaluated individual bias items as described in the Cochrane Handbook for Systematic Reviews of Interventions (Higgins 2011). A 'Risk of bias' graph (Figure 3) and 'Risk of bias' summary (Figure 4) are attached.

Figure 3. 'Risk of bias' graph: review authors' judgements about each risk of bias item presented as percentages across all included studies.

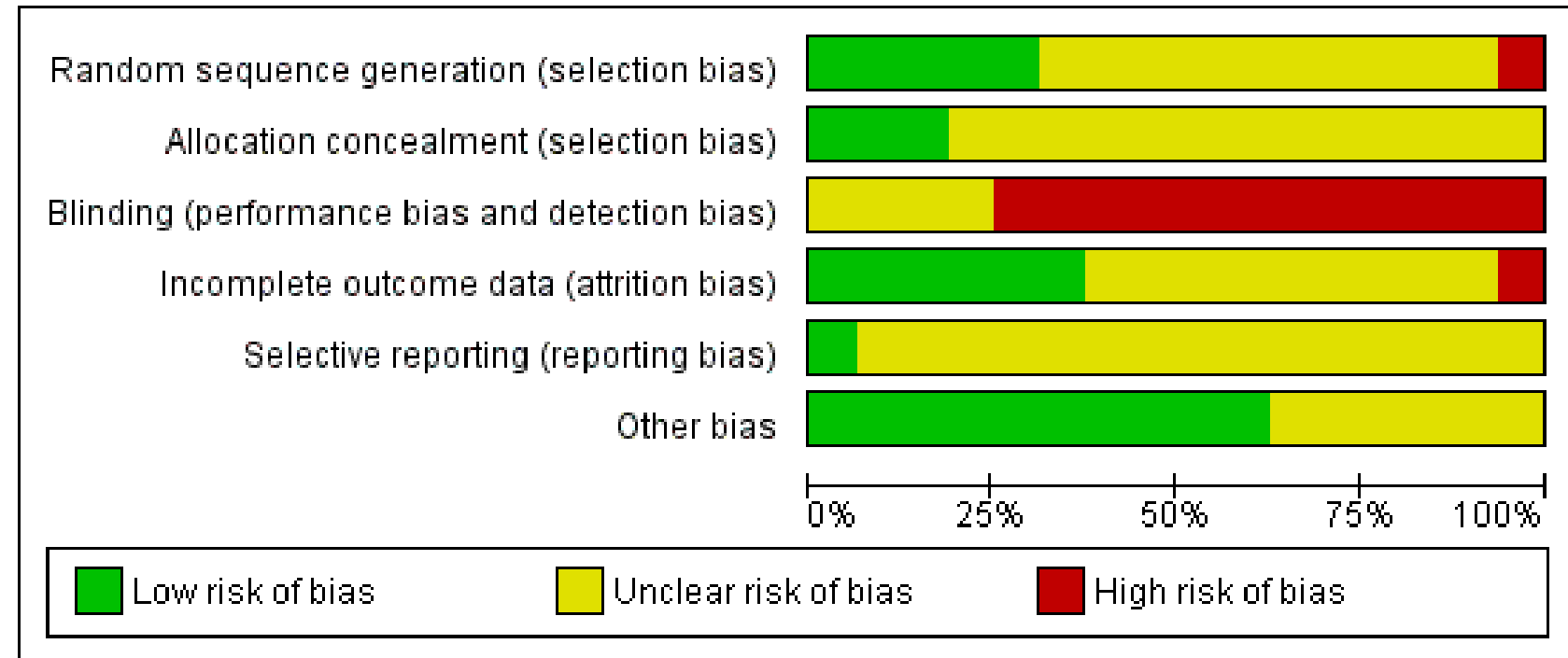


Figure 4. 'Risk of bias' summary: review authors' judgements about each risk of bias item for each included study.

\begin{tabular}{|c|c|c|c|c|c|c|}
\hline & 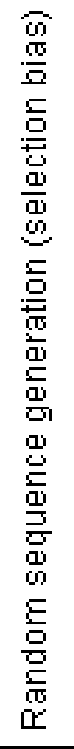 & 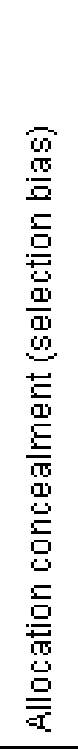 & 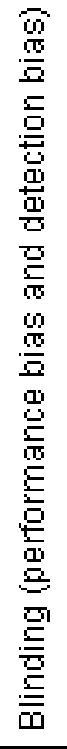 & 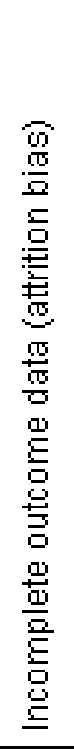 & 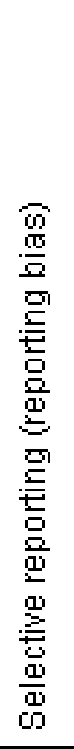 & 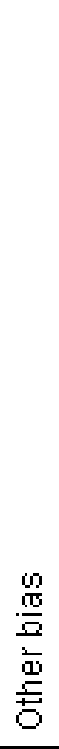 \\
\hline Christian 2008 & + & $\odot$ & & + & $?$ & $?$ \\
\hline Glasgow 1997 & $\odot$ & $?$ & $?$ & $?$ & $?$ & + \\
\hline Glasgow 2003 & $?$ & $?$ & $?$ & $?$ & $?$ & $?$ \\
\hline Glasgow 2005 & $?$ & $\odot$ & & $?$ & $?$ & + \\
\hline Glasgow 2006 & $?$ & $?$ & $?$ & + & $?$ & $?$ \\
\hline Glasgow 2010 & $\oplus$ & $?$ & $?$ & + & $?$ & + \\
\hline Leu 2005 & $\oplus$ & $\oplus$ & & $?$ & $?$ & + \\
\hline $\operatorname{Lim} 2011$ & $?$ & $?$ & & + & $?$ & + \\
\hline Lo 1996 & $?$ & $?$ & & $?$ & $?$ & + \\
\hline Lorig 2010 & + & $?$ & & + & $?$ & + \\
\hline Quinn 2008 & $?$ & $?$ & & $?$ & $?$ & $?$ \\
\hline Quinn 2011 & $?$ & $?$ & & - & + & $?$ \\
\hline Smith 2000 & $?$ & $?$ & & $?$ & $?$ & $?$ \\
\hline Wise 1986 & & $?$ & & $?$ & $?$ & $\oplus$ \\
\hline Yoo 2009 & $?$ & $?$ & & $?$ & $?$ & $\oplus$ \\
\hline Zhou 2003 & $?$ & $?$ & & 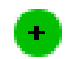 & $?$ & + \\
\hline
\end{tabular}




\section{Measures of treatment effect}

Self-management interventions are heterogenous in their aims and design. Two common outcomes that we thought would be shared by the majority of studies were $\mathrm{HbAlc}$ and health-related quality of life $(\mathrm{Q} O \mathrm{~L})$ measures (both are continuous data). Where studies provided sufficient data, we were able to look at the mean difference or difference in means for HbAlc. We planned to use standardised mean differences for QoL measures that used different scales, however, we were unable to do this due to insufficient data. The effects on QoL measures were therefore described narratively.

Given the heterogenous nature of the interventions, we analysed the theoretical basis for the interventions and tried to define in as much detail as possible the active components. We had planned to pool the results where there was evidence that the interventions being grouped shared approaches that draw on a similar theoretical basis, but there were not enough studies to do this.

\section{Unit of analysis issues}

We took into account the level at which randomisation occurred, such as cross-over trials, cluster-randomised trials and multiple observations for the same outcome. Two of the included studies were cluster-randomised trials (Glasgow 2005; Quinn 2011). We were unable to find suitable external estimates of intra cluster correlation coefficients and none were reported in the two clusterrandomised controlled trials included in the meta-analysis. These trials were included in the overall meta-analysis but a basic sensitivity analysis was done by repeating the meta-analysis without these studies.

\section{Dealing with missing data}

Relevant missing data were requested from trial authors. Evaluation of important numerical data such as numbers of screened, randomised patients as well as intention-to-treat (ITT), as-treated and per-protocol (PP) population were carefully performed. Attrition rates, for example dropouts, losses to followup and withdrawals were recorded. Issues of missing data and imputation methods (for example, last observation carried forward (LOCF)) were critically appraised.

\section{Assessment of heterogeneity}

Heterogeneity was identified by visual inspection of the forest plots, by using a standard $\mathrm{Chi}^{2}$ test and a significance level of $\alpha=0.1$, in view of the low power of this test. Heterogeneity was to be specifically examined with the 12 statistic quantifying inconsistency across studies to assess the impact of heterogeneity on the metaanalysis (Higgins 2002; Higgins 2003), where an 12 statistic of $50 \%$ to $90 \%$ may represent substantial heterogeneity and $30 \%$ to $60 \%$ may represent moderate heterogeneity (Higgins 2011).

When heterogeneity was found, we attempted to determine potential reasons for it by examining individual study and subgroup characteristics.

\section{Assessment of reporting biases}

A funnel plot was planned to assess for the potential existence of small study bias. However, there were too few studies to allow a meaningful assessment and therefore this has not been included in the review.

\section{Data synthesis}

Data were summarised statistically where possible when data were available, sufficiently similar and of sufficient quality. Statistical analysis was performed according to the statistical guidelines referenced in version 5.0.2 of the Cochrane Handbook for Systematic Reviews of Interventions (Higgins 2011). Where there were insufficient data to permit formal meta-analyses, we did a narrative synthesis.

\section{Applying the taxonomy of behaviour change techniques}

Two independent raters (KP and SE) piloted the taxonomy of behaviour change techniques (Michie 2011) on two studies. They underwent two cycles of an iterative process of independent coding, comparing results and discussion of differences and further refinement of the application of the taxonomy descriptions. Once good agreement was reached, KP and SE coded the intervention and control groups of the remaining studies, followed by re-coding of the pilot studies.

\section{Subgroup analysis and investigation of heterogeneity}

Where performed, subgroup analysis has been clearly marked as a hypothesis-generating exercise.

The following subgroup analyses were planned.

- Age.

- Gender.

- Behaviour change techniques used (based on proposed model for behaviour change).

- Education techniques used (to determine the most effective components of education).

- Duration of intervention (previous reviews have noted correlations between effect and duration of interventions).

- Duration of diabetes below or over five years (patients who have had diabetes for longer are likely to have more advanced disease and increased insulin resistance, more complications and are more likely to be on insulin therapy; any treatment modality may have smaller effects in more advanced disease).

- Different settings (primary care, outpatient or community settings) (likely to affect attrition: interventions that are more convenient for patients are likely to be better accepted and used but there may be some attraction for group interactions as well).

- Studies with participants with type 2 diabetes only (type 1 and type 2 diabetes tend to be more prevalent in very different age groups and have differences in aetiology and therefore may not respond the same way to the interventions).

There were sufficient data to perform subgroup analyses on the following.

- Duration of intervention.

- Settings: when looking at different settings, the distinction between primary care, outpatient or community setting could not be meaningfully applied to self-management interventions. It was more meaningful to divide the interventions settings into clinic-based (touch screen or other clinic computer), home computer-based and mobile phone-based interventions. 
- Studies with participants with type 2 diabetes only.

It was not possible to gather enough data to undertake the other planned subgroup-analyses.

\section{Sensitivity analysis}

We also planned to perform sensitivity analyses in order to explore the influence of the following factors on effect size.

- Restricting the analysis to published studies.

- Restricting the analysis taking into account risk of bias, as specified above.

- Restricting the analysis to very long or large studies to establish how much they dominate the results.

- Restricting the analysis to studies using the following filters: diagnostic criteria, language of publication, source of funding (industry versus other), country.

However, there were not sufficient data to perform these analyses. The robustness of the results was tested by repeating the analysis using different statistical models (fixed-effect model and randomeffects model).

\section{RES U L T S}

\section{Description of studies}

See: Characteristics of included studies; Characteristics of excluded studies

\section{Results of the search}

The search results from the six electronic bibliographic databases for published articles and conference proceedings yielded 8715 unique abstracts (4869 from The Cochrane Library, MEDLINE and EMBASE; 905 from PsychINFO and Web of Science and 2766 from CINAHL). The search results from the three online databases for theses contained 193 abstracts (44 from ASLIB Index to Theses, 28 from the Australasian Digital Theses programme and 121 from UMI PRoQuest Digital Dissertations). This is summarised in Figure 2. Two authors (KP and SE) independently screened the abstracts. Full papers were pulled for all abstracts that either author felt they could not confidently exclude. Ninety-four full-text articles were assessed for eligibility and assessed independently by two authors. Any papers where there was disagreement between the two authors were discussed in the steering group for elaboration and operationalisation of the eligibility criteria. Sixteen different studies with 3578 participants fulfilled the inclusion criteria and were selected for inclusion in the review.

\section{Included studies}

Sixeen studies met the inclusion criteria. A summary of the characteristics of the included studies can be found in the table Characteristics of included studies. Eleven studies were based in the USA (Christian 2008; Glasgow 1997; Glasgow 2003; Glasgow 2005; Glasgow 2006; Glasgow 2010; Leu 2005; Lorig 2010; Quinn 2008; Quinn 2011; Smith 2000), two studies in the United Kingdom (Lo 1996; Wise 1986), two studies in South Korea (Lim 2011; Yoo 2009) and one in China (Zhou 2003). Fifteen of the studies had reports published in English, one report was translated from Chinese (Zhou 2003).

\section{Study design}

All of the studies included in the review were randomised controlled trials. The duration of follow-up ranged from 2 to 12 months: two studies followed up for two months (Glasgow 2006; Zhou 2003), three studies followed up for three months (Lo 1996; Quinn 2008; Yoo 2009), one study followed up for four months (Glasgow 2010), two studies followed up for five months (Leu 2005; Smith 2000), three studies followed up for six months (Lim 2011; Lorig 2010; Wise 1986), one study followed up for 10 months (Glasgow 2003) and four studies followed up for 12 months (Christian 2008; Glasgow 1997; Glasgow 2005; Quinn 2011).

\section{Participants}

The included studies provided results from 3578 participants. The number of participants in a single study ranged from 30 (Quinn 2008; Smith 2000) to 886 (Glasgow 2005). One study only included women (Smith 2000). In 13 studies all participants had type 2 diabetes; three studies involved mixed populations with both type 1 and type 2 diabetes (Glasgow 1997; Leu 2005; Smith 2000); the percentage of participants with type 1 diabetes was about $20 \%$. Participants in one study were all Latino or Hispanic (Christian 2008). Three studies reported participants who were over $70 \%$ white or non-Hispanic white (Glasgow 2005; Glasgow 2006; Lorig 2010), although the last study had a separate arm which exclusively recruited American Indians and native Alaskans. Six studies reported mean duration of diabetes (Glasgow 1997; Lim 2011; Quinn 2008; Quinn 2011; Wise 1986; Yoo 2009) which ranged between 6 and 13 years. The mean age of participants ranged from 46 (Smith 2000) to 67 years (Lim 2011).

\section{Interventions}

\section{Duration}

The duration of the interventions varied. The shortest interventions were given to participants over four to six weeks (Lo 1996; Lorig 2010); longer durations were as follows: two months (Glasgow 2006; Zhou 2003); three months (Quinn 2008; Yoo 2009); four months (Glasgow 2010); five months (Leu 2005; Smith 2000); six months (Glasgow 1997; Lim 2011; Wise 1986); 10 months (Glasgow 2003); 12 months (Christian 2008; Glasgow 2005; Quinn 2011).

\section{Frequency and Intensity}

Patterns of use of the interventions varied widely across the different studies. Seven studies had interventions where exposure to the intervention was participant-driven and the frequency and intensity was mainly determined by how often and how long patients chose to use the intervention (Glasgow 2003; Glasgow 2010; Lorig 2010; Quinn 2008; Quinn 2011; Smith 2000; Zhou 2003). The remaining interventions were more prescriptive: six interventions were low intensity and the number of exposures to the intervention varied between one and four "doses". Two interventions used one interaction (Christian 2008; Glasgow 2005), two interventions used two interactions (Glasgow 1997; Glasgow 2006), one intervention used three interactions (Wise 1986) and one intervention used four interactions (Lo 1996). Three interventions were relatively intensive and had, on average, more than two interactions a day with participants (Leu 2005; Lim 2011; Zhou 2003). 


\section{Types of intervention}

Six interventions were clinic-based. One intervention was a brief touch screen assessment of dietary barriers (Glasgow 1997); one intervention was a 30-minute touch screen assessment and printout for action planning for self-management (Glasgow 2005); two interventions were computer-based assessments that also provided printouts for barriers to physical activity and diet (Christian 2008; Glasgow 2006); and two interventions provided computer-based education sessions (Lo 1996; Wise 1986).

Five interventions were Internet-based and were used from home. Four interventions provided peer support and education online, mostly through moderated forums (Glasgow 2003; Glasgow 2010; Lorig 2010; Smith 2000). One intervention used a computer to provide a tailored dietary plan for participants (Zhou 2003).

Five interventions used mobile devices. One study used pagers (Leu 2005) and four studies used mobile phones (Lim 2011; Quinn 2008; Quinn 2011; Yoo 2009). The pager study (Leu 2005) sent reminders about medication, blood glucose testing, exercise reinforcement, meal time reinforcement, laboratory results and custom participant-defined messages to participants and they were able to respond to messages. One of the mobile phonebased interventions (Yoo 2009) provided alarms for twice daily blood pressure and blood glucose measurements and daily weight measurement; it also provided texts with advice about lifestyle, exercise and tailored advice from health professionals. Another mobile phone-based intervention (Quinn 2008) used a blue tooth adapter to allow blood glucose data to be transferred to a mobile phone and use mobile phone-based software to generate personalised feedback. Lim et al (Lim 2011) described an intervention that sent text messages to participants based on self-monitored blood glucose levels with advice about medication or lifestyle. Quinn et al (Quinn 2011) used a mobile phone-based based software coach that delivered mostly automated messages in response to participant entered self-monitoring data.

The comparison group for five studies was usual care (Leu 2005; Lorig 2010; Quinn 2011; Wise 1986; Yoo 2009). Two studies provided printed information to participants (Christian 2008; Smith 2000). Two studies used touch screens for assessment or data collection but provided no feedback to participants (Glasgow 1997; Glasgow 2005). The remaining studies all used different controls; two studies provided face-to-face diabetes education in the control arm (Lim 2011; Lo 1996), one study provided blood glucose meters and encouraged participants to fax their results to their healthcare providers every two weeks until blood glucose was stabilised (Quinn 2008), one study provided fixed carbohydrate content meals decided by the doctor (Zhou 2003), one study provide computerbased access to articles about diabetes (Glasgow 2003) and two studies provided computer-assisted generic health risk appraisal (Glasgow 2006; Glasgow 2010).

\section{Outcomes}

A comprehensive description of the outcome measures outlined in the study reports is provided in Appendix 6.

\section{Primary outcomes}

\section{Health-related quality of life}

Five studies reported on health-related quality of life (Glasgow 2005; Glasgow 2006; Lorig 2010; Quinn 2011; Smith 2000).
They used four different scales - Problem Areas In Diabetes (PAID)-2 (Glasgow 2005), Diabetes distress scale (Glasgow 2006; Quinn 2011), Health distress scale (Lorig 2010) and Psychosocial adjustment to illness scale (PAIS) (Smith 2000).

\section{Death from any cause}

Two studies reported on the number of deaths of participants. One study reported one fatal event in the intervention arm (Leu 2005) and the other study reported the deaths of two participants (Lorig 2010, details of deaths not reported).

\section{Glycosylated haemoglobin A1c (HbA1c)}

All 16 studies mentioned glycosylated haemoglobin as an outcome measure. Eleven reports contained enough data to be included in a meta-analysis of 2637 participants (Christian 2008; Glasgow 2003; Glasgow 2005; Glasgow 2006; Glasgow 2010; Leu 2005; Lim 2011; Lorig 2010; Quinn 2011; Yoo 2009; Zhou 2003). Of the remaining studies, one reported a non-standardised measure of glycosylated haemoglobin (Lo 1996) and one study described self-reported HbA1C data (Smith 2000). The remaining reports did not contain enough data to be included in the meta-analysis (Glasgow 1997; Quinn 2008; Wise 1986).

\section{Secondary outcomes}

\section{Cognitions}

Change in knowledge and understanding: four studies reported on changes in knowledge (Lo 1996; Lorig 2010; Quinn 2008; Wise 1986), but there were insufficient data to combine in a meta-analysis.

Self-efficacy: two studies reported changes in self-efficacy (Lorig 2010; Quinn 2008).

\section{Behaviours}

Physical activity: five studies reported changes in physical activity (Christian 2008; Glasgow 2005; Glasgow 2010; Lorig 2010; Quinn 2008). Two studies measured changes in physical activity in minutes (Glasgow 2003; Lorig 2010), one study measured metabolic equivalent minutes (MET-min) per week (Christian 2008), one study looked at the mean number of days of exercise in a one week period (Quinn 2008) and one study recorded calories burned per week as determined by the 'Community Healthy Activities Model Program for Seniors ' (CHAMPS) questionnaire (Glasgow 2010).

Diet: six studies looked at changes in eating behaviours (Christian 2008; Glasgow 2003; Glasgow 2005; Glasgow 2010; Quinn 2008). One study looked at reported calorie intake per week (Christian 2008). Two studies looked at the Kristal Fat and Fiber behaviour scale and fat intake (Glasgow 1997; Glasgow 2003). One study looked at fruit and vegetable screener scores and daily fat intake (Glasgow 2006), one study looked at number of days per week of diabetes self-care for diet (Quinn 2008) and one study used the 'Starting the conversation' scale to measure healthy eating patterns (Glasgow 2010).

\section{Social support}

Change in social support: one study measured change in social support using the diabetes support scale (Glasgow 2003) and one study measured social support using the Personal Resource Questionnaire (PRS) (Smith 2000) 


\section{Biological markers}

Blood pressure: five studies looked at changes in blood pressure (Christian 2008; Glasgow 2010; Leu 2005; Quinn 2011; Yoo 2009). Two studies reported differences in mean systolic and diastolic blood pressures (Christian 2008; Quinn 2011), one study reported percentages of the groups that were hypertensive (Leu 2005), one study reported mean systolic and diastolic blood pressures (Yoo 2009) and one study reported mean arterial pressure (Glasgow 2010).

Blood lipid levels: ten studies reported blood lipid results (Christian 2008; Glasgow 1997; Glasgow 2003; Glasgow 2005; Glasgow 2006; Glasgow 2010; Lim 2011; Quinn 2011; Yoo 2009; Zhou 2003). Seven studies described total cholesterol, HDL and LDL levels (Christian 2008; Glasgow 2005; Glasgow 2006; Lim 2011; Quinn 2011; Yoo 2009; Zhou 2003). Two studies reported total cholesterol: HDL ratios (Glasgow 2003; Glasgow 2010). One study reported total cholesterol only (Glasgow 1997). Five studies reported triglyceride levels (Christian 2008; Lim 2011; Quinn 2011; Yoo 2009; Zhou 2003).

Body mass index (BMI)/weight: five studies reported changes in BMI (Glasgow 1997; Glasgow 2010; Lim 2011; Yoo 2009; Zhou 2003). Four studies reported changes in weight (Christian 2008; Glasgow 2006; Lim 2011; Yoo 2009).

\section{Complications}

Hospital admissions or emergency unit attendances: not reported in any of the studies.

\section{Emotional outcomes}

Anxiety or depression: six studies reported changes in depression. One study used the Centre for Epidemiologic depression scale (Glasgow 2003), two studies used PHQ-9 questionnaire scores (Glasgow 2006; Quinn 2011), one study reported changes in PHQ-9 score (Lorig 2010) and one study reported percentage of people in the groups with a PHQ-9 score of 10 or higher (Glasgow 2005). The final study looked at new diagnosis of depression in the intervention group (Quinn 2008).

\section{Other outcomes}

Episodes of hypoglycaemia: not reported in any of the studies. One study described the frequency of episodes as "infrequent" (Quinn 2011).

Adverse effects: one study reported a participant withdrawing due to anxiety related to the study (Wise 1986).

Cost-effectiveness and economic data: one study reported costeffectiveness data (Glasgow 1997) with costs per patients and costs per $1 \%$ reduction in fat intake and costs per unit reduction in cholesterol. One study reported changes in physician visits (Lorig 2010).

\section{Excluded studies}

Studies excluded from the review are described in Characteristics of excluded studies. The majority of studies excluded were telehealth interventions (44). They were excluded on the basis that the interventions did not fit our criteria for self-management interventions, rather they were tele-health interventions with the main aim of enabling health professional - patient interaction at a distance. Other reasons for exclusion included studies on participants with type 1 diabetes only (2), studies with more than $50 \%$ type 1 diabetes (2) and studies that were not randomised controlled trials (4). Of note, data in Figure 2 relate to exclusion of full-text articles.

\section{Risk of bias in included studies}

Details of the risk of bias of the included studies can be found in Characteristics of included studies and this has been summarised in Figure 3 and Figure 4. All of the included studies were randomised controlled trials but none were blinded. One study used an inadequate method of randomisation and was at high risk of bias (Wise 1986). The risk of bias in the remaining studies was unclear for some aspects as there was not sufficient detail in the report to make an assessment.

\section{Allocation}

Two studies used a random number table to generate the randomised sequences (Glasgow 1997; Lorig 2010). Two studies used a computer-generated random number sequence (Christian 2008; Glasgow 2010). One study used an Excel (TM) spreadsheet to randomly allocate participants (Leu 2005). One older study used inadequate randomisation by year and month of birth (Wise 1986). Reports for the remaining studies did not describe the method of generating the random number sequences.

Allocation concealment was done using padded envelopes in two studies (Christian 2008; Leu 2005) and these were assigned a low risk of selection bias.

\section{Blinding}

The study design for 11 of the included studies would make it difficult to blind the participants (Christian 2008; Leu 2005; Lim 2011; Lo 1996; Lorig 2010; Quinn 2008; Quinn 2011; Smith 2000; Wise 1986; Yoo 2009; Zhou 2003). The remaining studies did not comment on blinding of participants.

There was no comment on assessor blinding for 15 studies. One study used self-reported data collection; however patients were not blinded so the potential for performance and detection bias remained (Lorig 2010).

\section{Incomplete outcome data}

Four studies performed intention-to-treat analysis on the results (Christian 2008; Glasgow 2006; Glasgow 2010; Lorig 2010). One study used weighted estimating equations to address missing data (Quinn 2011); however, as the attrition rates were high in the intervention group (39\%) and differed significantly from the control group (10\%), we felt the results were at high risk of attrition bias. One study had no missing data (Zhou 2003). Four studies described their attrition rates which were between 4\% to 16\% (Glasgow 1997; Glasgow 2006; Lim 2011; Yoo 2009). The remaining studies did not provide details about missing data.

\section{Selective reporting}

We were able to find a published protocol for only one of the included studies (Quinn 2011). We found no evidence of selective reporting of outcomes. 


\section{Other potential sources of bias}

One study noted a larger reduction in $\mathrm{HbAlc}$ for patients in the control arm who had heir antihyperglycaemic drugs increased compared with the intervention group (Christian 2008). The control group for one study received a potentially active intervention that contained automated dietary change goals (Glasgow 2003).

\section{Effects of interventions}

See: Summary of findings for the main comparison

\section{Primary Outcomes}

\section{Health-related quality of life}

Five studies reported health-related quality of life scores (Glasgow 2005; Glasgow 2006; Lorig 2010; Quinn 2011; Smith 2000) but none showed statistically significant differences. In one study, both the control and the intervention group showed improvement on the PAID-2 scale (Glasgow 2005) but there was no significant difference between the two groups at 12 months. The study Lorig 2010 using the health distress scale showed no change between intervention and control groups at six months. Another study used PAIS (Smith 2000) and found no difference between intervention or control groups after five months. The final two studies using the diabetes distress scale (Glasgow 2006; Quinn 2011) showed no difference between control and intervention groups at two months and 12 months respectively.

\section{Death from any cause}

A total of three deaths out of 3578 participants were reported in the 16 studies. Two participants died in one study (Lorig 2010) and one participant died in another study from complications of a cerebrovascular attack (Leu 2005). No further details were provided in the study reports.

\section{HbA1c}

The effects of the interventions on HbAlc were mixed. One study relied on self-reported $\mathrm{HbA1C}$ monitoring and did not receive enough results to make any meaningful comment (Smith 2000). Of the remaining 15 studies the individual results were as follows: six studies reported small but statistically significant improvements in HbA1c (Lim 2011; Lorig 2010; Quinn 2008; Quinn 2011; Yoo 2009; Zhou 2003), three studies reported results that favoured the intervention but did not reach statistical significance (Glasgow 2003; Lo 1996; Wise 1986) and six studies reported no significant difference between control and intervention groups (Christian 2008; Glasgow 1997; Glasgow 2005; Glasgow 2006; Glasgow 2010; Leu 2005).

Eleven studies provided enough data to combine in a metaanalysis (Christian 2008; Glasgow 2003; Glasgow 2005; Glasgow 2006; Glasgow 2010; Leu 2005; Lim 2011; Lorig 2010; Quinn 2011; Yoo 2009; Zhou 2003) as shown in Figure 5. The pooled results indicate that there is a small, statistically significant difference in the outcomes between intervention and comparator groups of $2.3 \mathrm{mmol} / \mathrm{mol}$ or mean difference (MD) $-0.2 \%(95 \% \mathrm{Cl}-0.4$ to -0.1 ; 2637 participants, 11 trials, Analysis 1.1). There was substantial heterogeneity in the effects of the interventions $\left(I^{2}=58 \%\right)$.

Figure 5. Forest plot of comparison: $1 \mathrm{HbA1c}$, outcome: $1.1 \mathrm{HbA1c}[\%]$.

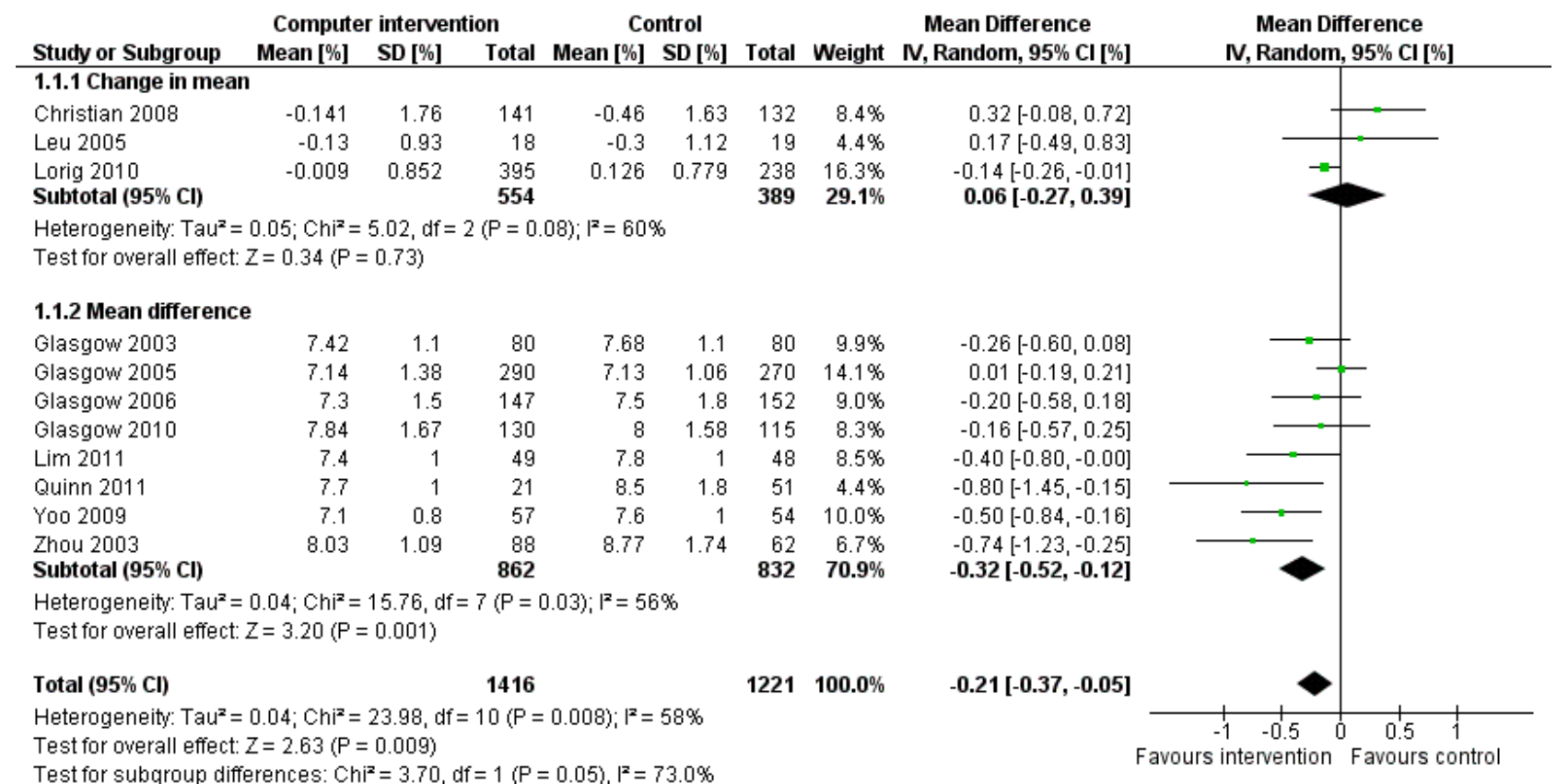

One study commented on a subgroup analysis looking at participants with higher HbA1c at baseline (Lorig 2010). Lorig 2010 found that for patients with a baseline $\mathrm{HbA1c}$ equal to or greater than $7.0 \%$, the difference between treatment and control arms increased from $-0.14 \%$ (overall) to $-0.6 \%(P=0.010)$ suggesting patients with $\mathrm{HbA1c}$ greater than $7 \%$ might benefit more than patients with better baseline glycaemic control.

Two studies seemed to favour the control group for HbAlc (Christian 2008; Leu 2005). Christian et al suggested a potential for 
bias in their report. Fifty-one per cent of participants in the study had their hypoglycaemic medication adjusted by their healthcare providers during the trial: the control group patients who had their medication changed saw their $\mathrm{HbAlc}$ reduce by $-0.9 \%$ while intervention group patients who had their medication changed saw their $\mathrm{HbAlc}$ reduced by just $-0.04 \%(P=0.02)$. The effect of the change in treatment of the control group appears to be much larger than the treatment effect of the interventions and could be a confounding factor. A subgroup analysis removing this study did not significantly change the heterogeneity of the overall metaanalysis $\left(I^{2}=56 \%\right)$ but the pooled effect of the interventions on $\mathrm{HbA1C}$ improved slightly to $-2.7 \mathrm{mmol} / \mathrm{mol}$ or $-0.3 \%(95 \% \mathrm{Cl}-0.4$ to -0.1 ; Analysis 1.2). Leu et al (Leu 2005) was the only study included in the meta-analysis carried out on a mixed population of people with type 1 and type 2 diabetes (74\% had type 2 diabetes). A subgroup analysis removing this study did not significantly change the heterogeneity of the overall meta-analysis $\left(I^{2}=56 \%\right)$ but the pooled effect of the interventions on $\mathrm{HbA1c}$ improved slightly to $-2.5 \mathrm{mmol} / \mathrm{mol}$ or $-0.2 \%(95 \% \mathrm{Cl}-0.4$ to -0.1 ; Analysis 1.3$)$.

\section{Secondary outcomes}

\section{Cognitions}

Change in knowledge and understanding: four of four studies reported positive effects of the interventions on knowledge (Lo 1996; Lorig 2010; Quinn 2008; Wise 1986). Lo et al (Lo 1996) showed an increase from 10.9 to 14.3 (mean scores) on the DKN diabetes knowledge scale but this was not significantly different to a control face-to-face education group. The intervention group in Quinn 2008 was more likely to report being able to better control their diabetes based on their knowledge of food choices compared with the control group ( $91 \%$ versus 50\%), measured using SDSCA diabetes self-care questionnaire. Wise 1986 showed a statistically significant increase in knowledge-based assessment scores expressed as a knowledge index. Lorig 2010 showed statistically significant improvements in knowledge, skill and confidence measures using the Patient Activation Measure (PAM) at six months and 18 months.

Self-efficacy: both studies measuring self-efficacy suggested positive effects of interventions (Lorig 2010; Quinn 2008). Lorig 2010 showed a statistically significant increase in self-efficacy at six months, measured on the diabetes self-efficacy scale, and this persisted up to 18 months after the start of the trial. Quinn 2008 used the SDSCA diabetes self-care questionnaire as above to show patients using the intervention were more likely to report being able to better control their diabetes based on their confidence (100\% versus $75 \%$ ).

\section{Behaviours}

Physical activity: the effects of interventions on physical activity were mixed. Christian 2008 showed that the percentage of intervention patients who achieved a metabolic equivalent minutes (MET- min equivalent) of 150 or more minutes of physical activity or exercise per week at a moderate level of intensity increased from $26 \%$ at baseline to $53 \%$ at 12 months ( $P=0.001)$, compared to the control group which showed an increase from $30 \%$ to $37 \%(P=0.27)$. Two studies showed small increases in physical activity that did not reach statistical significance (Glasgow 2003; Lorig 2010). One study reported statistically significant improvements in physical activity in the intervention group based on subgroup analysis (Glasgow 2010). One study found no improvement in diabetes self-care SDSCA questionnaire scores for exercise after three months (Quinn 2008).

Diet: six studies looked at changes in diet and five reported statistically significant improvements (Christian 2008; Glasgow 1997; Glasgow 2003; Glasgow 2006; Glasgow 2010; Quinn 2008). Glasgow 1997 demonstrated a statistically significant improvement in the food habits questionnaire and four-day food record in the intervention group. The intervention group in Glasgow 2003 showed a statistically significant improvement in Kristal Fat and Fiber Behavior (FFB) scale and the Block/NCl Fat Screener. The study Glasgow 2006 showed a significant and clinically meaningful reduction in dietary fat intake; however, there were no overall differences in fruit and vegetable consumption between control and intervention groups (Analysis 2.1). Quinn 2008 showed a statistically significant improvement in the diabetes self-care SDSCA score for diet. Glasgow 2010 reported a statistically significant improvement in healthy eating habits measured on the Starting the Conversation scale. Christian 2008 showed a statistically non significant improvement in the intervention group, who reduced total self-reported energy intake by a mean of 947 $\mathrm{kcal} / \mathrm{wk}(8.3 \%)$ per patient versus a $507 \mathrm{kcal} / \mathrm{wk}(4.4 \%)$ reduction for controls $(P=0.06)$, Analysis 2.3. When data about changes in dietary behaviour from three studies (Glasgow 2006; Glasgow 2010; Christian 2008) were combined in a meta-analysis (looking at dietary fat intake, healthy eating habits and energy intake respectively), it suggested a statistically significant improvement in dietary change scores from using computer-based interventions: pooled effect standardised mean difference (SMD) $-0.29(95 \% \mathrm{Cl}$ -0.43 to -0.15 ; 819 participants; 3 trials; Analysis 2.4 ).

\section{Social support}

Change in social support: Glasgow 2003 showed a small increase in diabetes total support scale from a baseline mean of 4.14 to $4.96, \mathrm{P}<0.05$. Smith 2000 measured social support using the Personal Resource Questionnaire (PRS) but there was no statistically significant change.

\section{Biological markers}

Blood pressure: Five studies looked at changes in blood pressure (Christian 2008; Glasgow 2010; Leu 2005; Quinn 2011; Yoo 2009). Two studies looked at differences in mean systolic and diastolic blood pressures and found no significant difference between intervention and control groups (Christian 2008; Quinn 2011). Glasgow 2010 reported mean arterial pressures and found no significant differences between control and intervention groups after four months. One study reported percentages of the groups that were hypertensive (Leu 2005) and found that at the end of the study $64 \%$ of intervention patients were "hypertensive" (not defined) in the intervention group compared with $68 \%$ in the control group $(P=0.041)$. Yoo 2009 reported mean systolic and diastolic blood pressures and found a statistically significant decrease in the intervention group - systolic blood pressure dropped from $127 \pm 14 \mathrm{~mm} \mathrm{Hg}$ to $120 \pm 19 \mathrm{~mm} \mathrm{Hg}, \mathrm{P}=0.001$ and diastolic blood pressure decreased from $78 \pm 10 \mathrm{~mm} \mathrm{Hg}$ to $74 \pm 8$ $\mathrm{mm} \mathrm{Hg}, \mathrm{P}<0.001$.

Blood lipid levels (Analysis 4.1; Analysis 4.2; Analysis 4.3; Analysis 4.4; Analysis 4.5; Analysis 4.6; Analysis 4.7; Analysis 4.8): Ten studies reported blood lipid results (Christian 2008; Glasgow 1997; Glasgow 2003; Glasgow 2005; Glasgow 2006; Glasgow 2010; Lim 2011; Quinn 2011; Yoo 2009; Zhou 2003). The results were mixed. Four studies 
found statistically significant improvements in blood lipid profiles: Christian 2008 - reduced total cholesterol and LDL, Glasgow 1997 reduced total cholesterol; Glasgow 2003, Yoo 2009 - reduced total cholesterol, LDL and triglycerides; however one of those studies (Christian 2008), attributed the difference in lipids to differences in the use of lipid-lowering medication. Six studies found no evidence of improvement in blood lipid levels in the intervention groups (Glasgow 2005; Glasgow 2006; Glasgow 2010; Lim 2011; Quinn 2011; Zhou 2003). Seven studies provided enough data to combine in a meta-analysis and the overall result was not statistically significant: pooled effect SMD -0.11 ( $95 \% \mathrm{Cl}-0.28$ to $0.05 ; 1625$ participants; 7 trials; Analysis 4.9 with subgroups).

Body mass index (BMI) and weight: five studies reported changes in BMI (Glasgow 1997; Glasgow 2010; Lim 2011; Yoo 2009; Zhou 2003). Four of those studies reported no significant difference in BMI between intervention or control groups (Glasgow 1997; Glasgow 2010; Lim 2011; Yoo 2009). The study Zhou 2003 showed a statistically significant drop in BMI from 24.0 to $23.1, \mathrm{P}<0.01$. Four studies reported changes in weight (Christian 2008; Glasgow 2006; Lim 2011; Yoo 2009). Christian 2008 reported that when mean changes in body weight were compared between intervention and control groups, no significant differences were found; however, $21 \%$ of intervention patients sustained a weight loss of $5 \%$ of total body weight or greater at 12 months compared with $10.6 \%$ of controls, $\mathrm{P}<0.01$ while $32 \%$ of intervention patients at 12 months had sustained a weight loss of $2.7 \mathrm{~kg}$ or more compared to $19 \%$ of control patients, $P=0.01$. Glasgow 2006 found a small but statistically significant reduction in weight in the intervention group of $0.7 \mathrm{~kg}, \mathrm{P}=0.007$. Yoo 2009 and Lim 2011 found no significant differences in the weight of intervention and control groups after three months and six months respectively. Five studies provided enough data to combine in a meta-analysis which showed no statistically significant evidence of benefit pooled effect: SMD -0.07 (95\% Cl -0.20 to $0.05 ; 1025$ participants; 5 trials; Analysis 3.1 with subgroups).

\section{Emotional outcomes}

Mood disorders (anxiety or depression): six studies that looked at depression showed no significant change in mood. Glasgow 2003 used the Centre for Epidemiologic depression scale but found no statistically significant improvement with the intervention. Three studies using PHQ-9 questionnaires did not show any statistically significant improvement in scores (Glasgow 2006; Lorig 2010; Quinn 2011). Two studies looked at incidence of depression in the intervention and control groups, and there was no statistically significant difference at the end of the trial (Glasgow 2005; Quinn 2008).

\section{Other outcomes}

Adverse effects: one study reported a participant withdrawing due to anxiety related to the study (Wise 1986). One study noted nonstatistically significant increase in minor hypoglycaemic episodes in the intervention group but no difference in major or nocturnal hypoglycaemic episodes (Lim 2011). Quinn 2011 specifically stated there were no study-related adverse events.

Cost-effectiveness and economic data: Glasgow 1997 looked at the cost per patient for a touch screen dietary intervention. Depending on the volume of patients seen, the cost per patient in 1997 ranged from $\$ 115$ to $\$ 139$, with a cost per unit reduction of cholesterol between $\$ 7$ to $\$ 8.40$ and a cost per $1 \%$ reduction in fat of $\$ 52$ to
$\$ 63$. One study looked at health behaviour and resource utilisation but found no significant difference between intervention or control groups (Lorig 2010).

\section{Behaviour change techniques}

The behaviour change techniques used in each intervention are described in Appendix 9. These have been grouped according to their apparent impact on HbAlc when used in interventions included in this systematic review in Appendix 10. The two behaviour change techniques used most commonly by interventions that had a significant impact on $\mathrm{HbAlc}$ were: Prompt self-monitoring of behavioural outcome and Provide feedback on performance. In contrast, Provide information on consequences of behaviour in general, Goal setting (behaviour) and Barrier identification/Problem solving were the behaviour change techniques most commonly associated with interventions that had no significant impact on HbAlc.

The published reports of studies involving complex interventions are seldom reported in enough detail to replicate them (Michie 2009). This was true of the studies included in this review, limiting the possibility of specifying interventions in terms of their component behaviour change techniques or identifying their likely mechanisms of action. Those we were able to identify are listed in Appendix 9. Since there were not enough studies to conduct a meta-regression to investigate which techniques were effective, an exploratory exercise was conducted by considering the techniques that featured most commonly in effective, compared with ineffective interventions and inspecting patterns of association between techniques and the effective with effective interventions (Appendix 10). Prompting self-monitoring of behavioural outcomes and providing feedback on performance were the most commonly used techniques in interventions that had a statistically significant impact on $\mathrm{HbAlc}$, while providing information on the consequences of behaviour, goal setting and barrier identification/problem solving were the most commonly used techniques in ineffective interventions.

There is a cluster of techniques associated with positive outcomes that have been identified in meta-regression analyses of interventions to increase physical activity and healthy eating (Dombrowski 2011; Michie 2009a; Michie 2012). The cluster of techniques is consistent with Control Theory (Carver 1982) which postulates that there is a synergistic association between receiving information about one's behaviour (via 'self-monitoring' or 'feedback') and having a strategy for acting on this information ('action planning' or 'information on where and when to perform the behaviour'). The former provides a cue and/or motivation for the latter.

Overall, in the interventions we looked at in this review, goal setting was associated with ineffective interventions - in contrast to the evidence cited above. This may be because goal setting was very rarely included in the same interventions as feedback or self-monitoring. Five interventions used goal setting as part of the intervention (Christian 2008; Glasgow 1997; Glasgow 2005; Glasgow 2006; Glasgow 2010) - but only one of the interventions provided feedback on how the participant was doing (Glasgow 2010). Control theory would predict that goal setting would be less effective if presented without feedback. The finding may also be the result of goals being suggested by health professionals or computer programs rather than being set by participants themselves or in a 
collaborative way; however, this level of detail was not provided in the descriptions of the interventions in published reports.

\section{Classification using taxonomy for education}

There were too few papers with too little detail about the education components to allow meaningful use of the taxonomy for educational interventions.

\section{Subgroup analysis}

A previous meta-analysis of diabetes self-management interventions (18/20 were face-to-face) showed a greater effect from shorter studies with short-term follow-up (Minet 2010). Therefore. we performed a subgroup analysis to see if there was any suggestion this hypothesis might also be true for computer-based self-management interventions. The studies were divided into short-to-medium term outcomes (follow-up less than six months) and medium-to-long term outcomes (follow-up for six months or longer). When outcomes at less than six months were combined (Glasgow 2006; Glasgow 2010; Leu 2005; Yoo 2009; Zhou 2003), heterogeneity was reduced $\left(I^{2}=43 \%\right)$ with a larger effect size for $\mathrm{HbA} 1 \mathrm{c}$ of $-3.5 \mathrm{mmol} / \mathrm{mol}$ or $-0.3 \%(95 \% \mathrm{Cl}-0.6$ to -0.1 ; Analysis 1.6$)$. Combining studies with outcomes measured at six months or later (Christian 2008; Glasgow 2003; Glasgow 2005; Lim 2011; Lorig 2010; Quinn 2011), the overall effect size for $\mathrm{HbA1c}$ was smaller and no longer statistically significant: MD $-1.5 \mathrm{mmol} / \mathrm{mol}$ or $-0.1 \%(95 \% \mathrm{Cl}$ -0.3 to 0.1 ; Analysis 1.7$)$. Heterogeneity was still substantial $\left(I^{2}=\right.$ $61 \%)$.

A recent meta-analysis of the effect of mobile phone intervention for diabetes on glycaemic control (Liang 2011) suggested that mobile phone-based interventions led to statistically significant improvements in glycaemic control and self-management in diabetes care, especially for patients with type 2 diabetes. Combining the three mobile phone-based interventions in the meta-analysis (Lim 2011; Quinn 2011; Yoo 2009) found a statistically and clinically significant reduction in $\mathrm{HbAlc}$ of $-5.5 \mathrm{mmol} / \mathrm{mol}$ or MD of $-0.5 \%(95 \% \mathrm{Cl}-0.7$ to -0.3$)$ and heterogeneity decreased dramatically $\left(I^{2}=0 \%\right.$; Analysis 1.8$)$. Interventions delivered at home (Glasgow 2003; Glasgow 2010; Lorig 2010; Zhou 2003) appeared to have a smaller effect: MD $-2.7 \mathrm{mmol} / \mathrm{mol}$ or $-0.3 \%(95 \% \mathrm{Cl}$ -0.5 to $-0.04 \%$ ) and the result was still associated with moderate heterogeneity $\left(I^{2}=47 \%\right.$; Analysis 1.9$)$.

\section{Sensitivity analysis}

There were insufficient data to perform most of the sensitivity analyses proposed in the protocol stage. The studies that had mixed populations of type 1 and type 2 diabetes did not have enough data to be used in the main meta-analysis. Using a fixed-effect model for the meta-analysis of effects of the interventions on $\mathrm{HbAlc}$, the pooled effect on $\mathrm{HbA} 1 \mathrm{c}$ is $-1.7 \mathrm{mmol} / \mathrm{mol}$ or $-0.2 \%(95 \% \mathrm{Cl}-0.3$ to -0.1) - smaller than when using the random-effects model, but still statistically significant.

A sensitivity analysis to look at unit of analysis issues was carried out by removing two studies that were cluster-randomised (Glasgow 2005; Quinn 2011; Analysis 1.4). The pooled effect on $\mathrm{HbA1c}$ increased slightly to a MD of $-2.4 \mathrm{mmol} / \mathrm{mol}$ or $-0.2 \%(95 \% \mathrm{Cl}$ -0.4 to -0.1 ) and remained statistically significant.

One study included in the meta-analysis (Glasgow 2003) did not provide details of numbers of participants in each group. It was assumed that equal numbers of participants were allocated to each arm of the trial but no allowance was made for attrition and therefore, the study is likely to be over-powered in the final meta-analysis. Removing this study from the meta-analysis had no significant effect on the results other than slightly smaller confidence intervals: pooled effect size is a MD of $-2.3 \mathrm{mmol} / \mathrm{mol}$ or $-0.2 \%(95 \% \mathrm{Cl}-0.4$ to $-0.04 \%$; Analysis 1.5$)$.

\section{DISCUSSION}

\section{Summary of main results \\ Primary outcomes}

Sixteen randomised controlled trials with 3578 participants were included in the review. These studies included a wide spectrum of interventions covering clinic-based brief interventions, Internetbased interventions that could be used from home and mobile phone-based interventions. The mean age of participants was between 46 to 67 years old and mean time since diagnosis was 6 to 13 years. The duration of the interventions varied between 1 to 12 months.

Eleven studies provided enough data about glycaemic control to use $\mathrm{HbA1C}$ in a meta-analysis. The pooled results indicate that there is a small, statistically significant difference in the outcomes between intervention and comparator groups of $-2.3 \mathrm{mmol} / \mathrm{mol}$ or $-0.2 \%(95 \% \mathrm{Cl}-0.4$ to -0.1$)$ that favours the interventions (Analysis 1.1). This was associated with substantial heterogeneity $\left(I^{2}=58 \%\right)$ suggesting inconsistencies between the effects of the different interventions. However, the impact on HbAlc was larger in the mobile phone subgroup with a pooled effect on $\mathrm{HbA1c}$ from three studies of $-5.5 \mathrm{mmol} / \mathrm{mol}$ or $-0.5 \%(95 \% \mathrm{Cl}-0.7$ to -0.3$)$ and no heterogeneity $\left(I^{2}=0 \%\right.$; Analysis 1.8$)$. The effects of computer-based interventions may wear off over time as combining results from studies lasting six months or longer showed the overall effect size for $\mathrm{HbA1c}$ was smaller and no longer statistically significant: -1.5 $\mathrm{mmol} / \mathrm{mol}$ or $-0.1 \%(95 \% \mathrm{Cl}-0.3$ to 0.1 ; Analysis 1.7$)$.

Five studies looked at health-related quality of life (Glasgow 2005; Glasgow 2006; Lorig 2010; Quinn 2011; Smith 2000), but there was no evidence to show any significant improvement with the computer-based interventions.

A total of three deaths out of 3578 participants was reported in the 16 studies.

\section{Cognitive impact of computer-based diabetes self- management interventions}

There was some evidence to show computer-based interventions have positive effects on two possible mediators: knowledge and self-efficacy. However, there seemed to be difficulty in converting the positive effects on knowledge and self-efficacy into behavioural change such as physical activity: in only two out of five studies did there appear to an increase In physical activity.

Six studies measured effects on diet and five showed some statistically significant improvements in questionnaire scores but the clinical benefits and impact on health outcomes of these changes is unknown as the effects of interventions on weight or body mass index (BMI), were not convincing with no statistically significant improvements in weight seen when the results from five studies were combined in a meta-analysis (Figure 6). 
Figure 6. Forest plot of comparison: 4 Weight, outcome: 4.1 Weight.

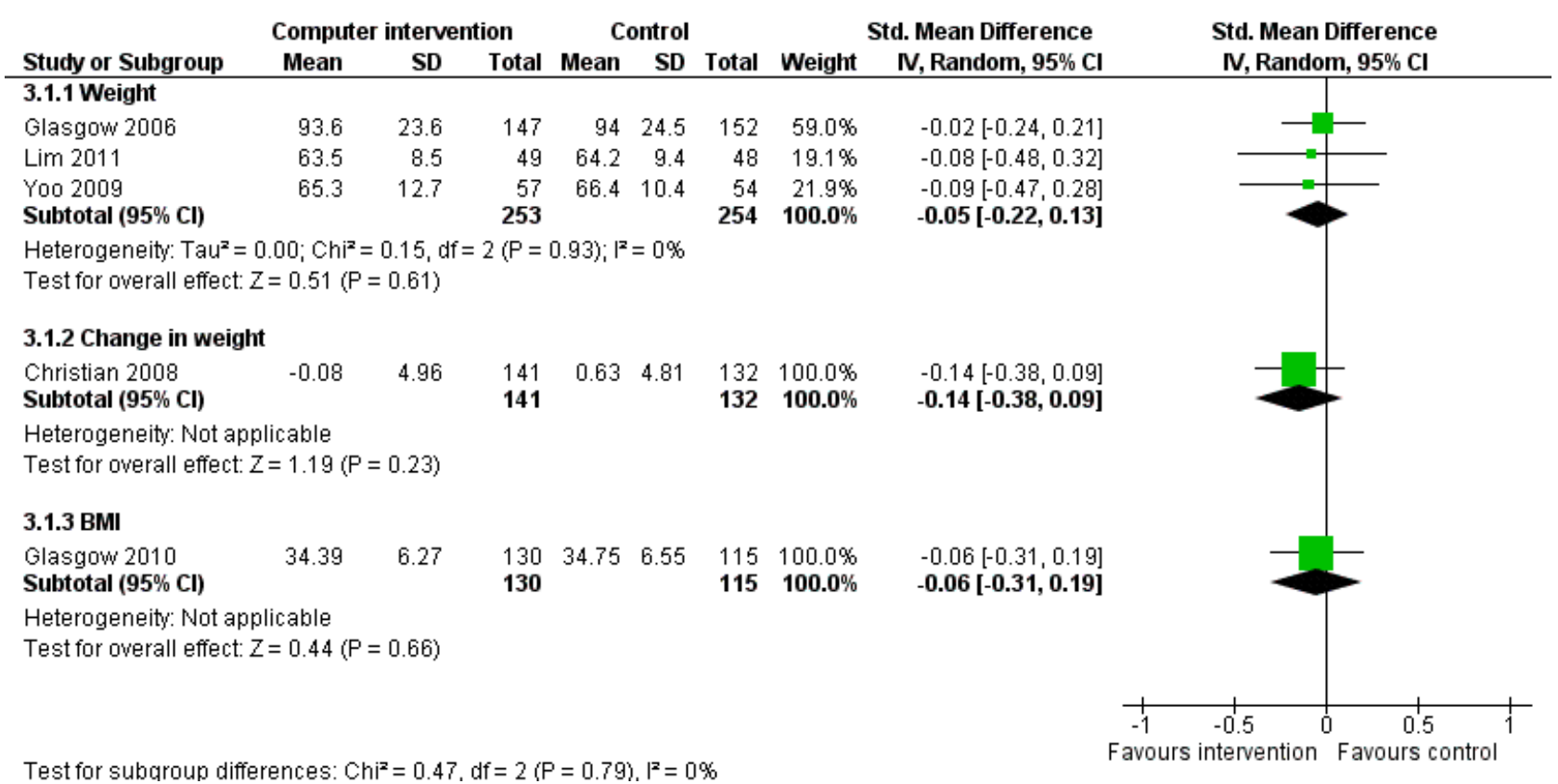

\section{Effect of the interventions on biological outcomes}

The evidence for computer-based self-management interventions improving blood pressure was mixed. A brief touch screen intervention aimed at increasing physical activity had no significant effect on blood pressure but two more intensive interventions - a pager intervention and a mobile phone-based intervention showed statistically significant improvements in blood pressure. This might suggest that improving blood pressure requires more frequent interactions and helps increase adherence with medication.

Effects of these interventions on cholesterol were quite mixed. Four studies showed evidence of improvement, three showed no difference. One of the studies that demonstrated a statistically significant improvement in lipid profile attributed this effect to changes in medication rather than the intervention - so it appears there were three studies showing benefits and three showing no difference. Overall, when seven studies providing sufficient data were combined in a meta-analysis, the pooled effect showed no statistically significant effects (Analysis 4.9).

\section{Behaviour change techniques used by the intervention and mechanisms of action}

On the subgroup analysis looking at mobile phone-based interventions (Lim 2011; Quinn 2011; Yoo 2009), all of these interventions provided feedback on performance and provided prompts or cues for desired behaviour around blood glucose selfmonitoring (see Appendix 11). This subgroup was associated with a larger improvement in HbAlc than other interventions, which suggests that the effects of interventions for blood glucose selfmonitoring might be explained by control theory. Developing an understanding of the theoretical basis of effective interventions can inform the future development of more effective interventions.

\section{Definitions of self-management interventions in the literature}

There is currently no clear distinction in the literature between interventions that use information technology to deliver computerbased behaviour change support and interventions that use information technology to deliver health professional-based behaviour change support. This review was intended for the former but it was often difficult to make the distinction from study reports.

\section{Overall completeness and applicability of evidence}

We identified sixteen randomised controlled trials (RCTs) with 3578 participants that met our inclusion criteria. These studies included a wide spectrum of interventions covering clinic-based brief interventions, Internet-based interventions that could be used from home and mobile phone-based interventions. All the studies included in the meta-analysis were on patients with type 2 diabetes only and mixed-gender populations. The studies were carried out in four different countries (USA, UK, China and South Korea), one study was carried out on Latin/Hispanic patients and one study had a separate arm for native Alaskans/American Indians (not controlled so the results have not been included in this review). Fifteen studies were published in English, one was translated from Chinese.

On average, patients were aged between 46 to 67 years old and had lived with diabetes for 6 to 13 years. The (mean) age range of participants in the included studies was relatively small.

This review only focused on computer-based self-management interventions, not tele-health interventions. We were looking for interventions that could be used by patients on their own and not just used to communicate with healthcare professionals. We therefore excluded a number of remote case-management interventions and tele-health interventions. 


\section{Quality of the evidence}

All of the studies included in the review are RCTs but the quality of the trials was variable. Most studies did not provide details about the randomisation process and assessor blinding so it is difficult to make a judgement about how biased some of the studies are. The nature of some of the trials and the intervention/ control combination would have made it impossible to blind the participants. Some of the control groups had quite active treatment - e.g. apparent significant increases in hypoglycaemic medication, a control arm that included goal setting or increased monitoring by healthcare providers - that might reduce the apparent effectiveness of the interventions.

Most of the study reports did not provide details about how hypoglycaemic medication changed in groups over the duration of the trials. Potentially this is an important issue - one study (Christian 2008) suggested that the control group had significantly larger increases in hypoglycaemic medication during the study as part of usual care and this is why the control group had better glycaemic control at the end of the trial. However, the opposite is also possible - if better informed or self-managing patients take more interest in their treatment and are therefore more likely to increase their medication then the success of these interventions would be due to improved concordance with treatment rather than due to changes in lifestyle. If computer-based self-management interventions mainly act through improving effectiveness of existing treatments rather than directly affecting patient outcomes this would still be an important potential benefit of these interventions as long as this was due to change in patient behaviour. However, if intervention groups had their medication increased by their medical teams simply due to increased monitoring as part of trial procedures, it would not be appropriate to describe this as a beneficial effect of the interventions.

The interventions appear to be quite heterogenous and the length of follow-up varied from 2 to 12 months. All the interventions looked at effects on $\mathrm{HbAlc}$ as an important outcome, but the other primary and secondary outcomes varied greatly and the instruments used to measure them were often different, which made it very difficult to compare or synthesise the results from different studies.

\section{Potential biases in the review process}

The searches were performed on electronic bibliographic databases but most of these were medical. We did not explore non-medical sources so we might have missed some computerbased research. Intervention descriptions were usually brief so in spite of clearly defining our intervention in the protocol, deciding which interventions fitted our definition of a computer-based self-management intervention often required discussion with the steering group and judgements based on limited descriptions and interpretation. Although we looked for unpublished data, we were unable to find any unpublished RCTs that fulfilled the inclusion criteria so the review contains published data only. The complex nature of these interventions meant that there were a large number of primary and secondary outcomes for which data were extracted but these were specified in advance in the protocol and we have only reported on outcomes specified in the protocol.

\section{Agreements and disagreements with other studies or reviews}

\section{Overall effects of computer-based diabetes self-management interventions}

The current evidence on the use of new technology in diabetes is still evolving and has shown mixed results. A Cochrane systematic review of interactive healthcare applications looked at 24 RCTs in a range of chronic diseases and found mostly positive effects on users, with users tending to become more knowledgeable, feel better supported, with possible improved behavioural and clinical outcomes compared with non-users (Murray 2005). This review also identified a need for more high-quality studies with large sample sizes to confirm these findings.

Another systematic review looked at 26 studies of interactive computer-assisted technology in diabetes care (Jackson 2006). The reviewers felt the data were too heterogeneous for a metaanalysis and provided a narrative report. It identified 14 studies that looked at $\mathrm{HbA} 1 \mathrm{c}$ levels and found that 6 of 14 studies demonstrated significant declines in HbAlc. Studies that looked at changes in body weight, blood pressure, micro-albuminuria and renal function found no significant differences post-intervention, while effects on lipids and depression were mixed. The interventions also appeared to improve healthcare utilisation with more foot examinations and $\mathrm{HbA1C}$ monitoring but had no effect on hospital admissions.

On the other hand, a meta-analysis looking at computer-delivered interventions for health promotion found seven RCTs with elements of diabetes self-management and found no evidence to support their use (Portnoy 2008). It found that in general, computerdelivered interventions could lead to immediate post-intervention improvements in cognitive elements such as knowledge, attitudes and intentions and help modify behaviours such as dietary intake, tobacco use, safer sex and general health behaviours, but found no evidence to support computer interventions for more complex behaviour change such as diabetes self-management. However, the outcome measures and data analysis used to come to this conclusion about diabetes self-management were not described in any detail and it acknowledged the relative paucity of evidence in the field.

A review of the effectiveness of information (IT)-based diabetes management interventions looked at 15 studies of which nine were RCTs (Costa 2009). The authors felt that due to the limitations of the studies reviewed, the effectiveness of existing IT-based interventions was unclear and difficult to attribute solely to the interventions. The review concluded that future research efforts needed to focus on methodological issues to produce valid, reliable and generalisable findings.

\section{Mode of delivery}

A more recent review focused only on the effect of mobile phone interventions for diabetes on glycaemic control (Liang 2011) and reported on a meta-analysis of 22 trials with 1657 participants. This showed that mobile phone interventions for diabetes selfmanagement reduced $\mathrm{HbAlc}$ values by a mean of $6 \mathrm{mmol} / \mathrm{mol}$ or $0.5 \%(95 \% \mathrm{Cl} 0.3$ to 0.7$)$ over a median follow-up duration of six months. This is similar to the effect size seen in this review when the effects of the three mobile phone interventions (Lim 2011 ; Quinn 2011; Yoo 2009) were pooled. 


\section{Duration and intensity of interventions}

A meta-analysis of 47 randomised controlled trials of self-care management intervention in type 2 diabetes has been mentioned previously (Minet 2010). The meta-regression undertaken in this review suggested that 1 . self-care management interventions might have a higher effect if the programme was compact with sessions closely grouped together; and 2. the effect of selfcare management interventions might decrease over time. The authors suggested that providing sessions more closely grouped together, as noted in the shorter interventions, might have allowed participants to remember and better synthesise the information, thus potentially increasing their effectiveness.

\section{Effects on diet and weight}

A recent systematic review looked for evidence that the use of interactive electronic media to facilitate dietary behaviour change and found no evidence of their effectiveness and that they were at least as expensive as other individual behaviour change interventions (Harris 2011).

\section{Summary}

This review supports the findings of the reviews above which suggest that, although popular, computer-based diabetes selfmanagement interventions have limited evidence supporting their use. These interventions are poorly understood and more research is needed into their design, delivery and effectiveness and future interventions would benefit from evidence-based components and more detailed reporting and evaluation. This review also supports the suggestions that 1 . mobile phone-delivered interventions may be more effective than interventions delivered over the Internet and 2. compact programmes with frequent sessions might be more effective, but the benefits could be short-lived.

\section{AUTHORS' CONCLUSIONS}

\section{Implications for practice}

Computer-based diabetes self-management interventions to manage type 2 diabetes appear to have a small beneficial effect on blood glucose control and the effect was larger in the mobile phone subgroup - possibly due to interventions using control theory being more effective than interventions based on other theories. Existing interventions do not show adequate evidence as ways of improving other biological outcomes or any cognitive, behavioural or emotional outcomes.

\section{Implications for research}

There were a number of questions raised in the introduction section of this review to describe why we felt this review was important. The bulk of this review has tried to answer the first question about the efficacy of computer-based self-management interventions for adults with type 2 diabetes, but data on the remaining questions were insufficient. We therefore suggest that the following aspects are important for future research in this area.

\section{Uncertainty about active components - how do they work?}

1. The small treatment effect $(2.3 \mathrm{mmol} / \mathrm{mol}$ or $0.2 \%)$ on glycosylated haemoglobin $\mathrm{A} 1 \mathrm{c}(\mathrm{HbA} 1 \mathrm{c})$ with computer-based self-management interventions is a difference that would be important if it could be achieved and sustained across the population via the Internet at very low cost, but far from cost-effective if it required significant nursing support and/or additional drugs. However, there is currently no clear distinction in the literature between interventions that use information technology (IT) to deliver relatively automated computer-based behaviour change support, and those interventions that use information technology to deliver health professional-based behaviour change support by using IT for remote consultations ('tele-health'). In view of the adoption of such interventions based on potential cost-effectiveness, making that distinction is likely to be important and it would be helpful if interventions were designed, described and tested with that in mind.

2. There were few published protocols for the studies and the theoretical basis, active ingredients and 'dose' of the intervention were not always clearly described in the published reports. As these interventions are therapeutic agents, it may be beneficial to explicitly 'prescribe' interventions for trials and formally state the active ingredients (behaviour change techniques), dose (frequency and intensity of interactions), route (mode of delivery - Internet, mobile phone etc) and duration of treatment.

3. It is not clear why interventions delivered over mobile phones appear to be more effective - it could be due to convenience (and therefore adherence), intensity of the interventions (mobile phone interventions were more likely to have multiple daily contacts) or the behaviour change techniques used by the interventions (mobile phone interventions were more likely to use cues to prompt behaviour and provide rapid feedback afterwards).

4. Given the heterogeneity in design, reporting and effect of computer-based interventions it is also important to find the most effective components or behaviour change techniques to achieve the desired impact.

5. Interventions are more likely to be effective if the selection and combination of behaviour change techniques is informed by appropriate behaviour change theories. For example, the interventions in this review often used goal setting as a behaviour change technique but failed to provide feedback on performance. The design of interventions should follow systematic, scientific procedures, including being better informed by theory and evidence.

6. Most studies did not report on any changes in hypoglycaemic medication in intervention or control groups. Without that information it is difficult to determine whether changes in $\mathrm{HbAlc}$ are due to changes in behaviour or changes in medication. It is possible that the benefits of self-management interventions might be due to better concordance with existing treatment or more intensive treatment requested by more engaged patients. It would be helpful if future studies provided more detail on changes in hypoglycaemic medication during the study to explore this further.

\section{What is the clinical significance of any reported benefits of these interventions?}

1. All the studies that looked for improvements in possible mediators such as knowledge and self-efficacy reported positive effects, but more research is needed into translating those improvements into improvements in health outcomes.

2. It is also currently not obvious what the clinical significance of the small improvements in diet and blood pressure seen in 
current interventions is likely to be, so more research is needed on this.

3. This review suggests that current interventions do not improve depression, weight loss, physical activity or blood lipid profiles so interventions to target these areas need to be designed differently to existing interventions.

\section{Are they cost effective? What harm can come from computer- based interventions?}

More studies need to be done looking at the cost-effectiveness of different types of computer-based interventions. Studies with longer follow-up are needed to determine the long-term impact on health outcomes of these interventions and look for evidence of harm.

\section{Which populations and sub-populations do they benefit?}

There also needs to be more research to determine which population groups will benefit the most from these interventions, e.g. HbAlc greater than $53 \mathrm{mmol} / \mathrm{mol}$ or $7 \%$. It would also be important to explore the impact of these interventions on older patients. However, it is important to consider that older patients would include people with new onset type 2 diabetes that is slowly progressive, and those that have long-standing diabetes with more advanced disease and the same intervention might not be appropriate for both groups.

\section{ACKNOWLEDGEMENTS}

We would like to thank Dr P J Edwards, Senior Lecturer in Statistics, Department of Population Health, London School of Hygiene \& Tropical Medicine for his help with preparing the statistical analysis for the review. 


\section{R E F E R E N C E S}

\section{References to studies included in this review}

Christian 2008 \{published data only\}

Christian JG, Bessesen DH, Byers TE, Christian KK, Goldstein MG, Bock BC. Clinic-based support to help overweight patients with type 2 diabetes increase physical activity and lose weight. Archives of Internal Medicine 2008;168(2):141-6.

\section{Glasgow 1997 \{published data only\}}

Glasgow RE, La Chance PA, Toobert DJ, Brown J, Hampson SE, Riddle MC. Long-term effects and costs of brief behavioural dietary intervention for patients with diabetes delivered from the medical office. Patient Education and Counselling 1997;32(3):175-84.

\section{Glasgow 2003 \{published data only\}}

Glasgow RE, Boles SM, Mckay HG, Feil EG, Barrera M. The $D$-Net diabetes self-management program: long-term implementation, outcomes and generalization results. Preventive Medicine 2003;36(4):410-9.

\section{Glasgow 2005 \{published data only\}}

Glasgow RE, Nutting PA, King DK, Nelson CC, Cutter G, Gaglio B, et al. Randomized effectiveness trial of a computerassisted intervention to improve diabetes care. Diabetes Care 2005;28(1):33-9.

\section{Glasgow 2006 \{published data only\}}

Glasgow RE, Nutting PA, Toobert DJ, King DK, Strycker LA, Jex M, et al. Effects of a brief computer-assisted diabetes selfmanagement intervention on dietary, biological and quality-oflife outcomes. Chronic Illness 2006;2(1):27-38.

\section{Glasgow 2010 \{published data only\}}

Glasgow RE, Kurz D, King D, Dickman JM, Faber AJ, Halterman E, et al. Outcomes of minimal and moderate support versions of an internet-based diabetes self-management support program. Journal of General Internal Medicine 2010;25(12):1315-22. [PUBMED: 20714820]

\section{Leu 2005 \{published data only\}}

Leu MG, Norris TE, Hummel J, Isaac M, Brogan MW. A randomized, controlled trial of an automated wireless messaging system for diabetes. Diabetes Technology and Therapeutics 2005; 7(5):710-8.

\section{Lim 2011 \{published data only\}}

Lim S, Kang SM, Shin H, Lee HJ, Won YJ, Yu SH, et al. Improved glycemic control without hypoglycemia in elderly diabetic patients using the Ubiquitous Healthcare Service, a new medical information system. Diabetes Care 2011;34(2):308-13. [U231]

\section{Lo 1996 \{published data only\}}

Lo R, Lo B, Wells E, Chard M, Hathaway J. The development and evaluation of a computer-aided diabetes education program. Australian Journal of Advanced Nursing 1996;13(4):19-27.
Lorig 2010 \{published data only\}

Lorig K, Ritter PL, Laurent DD, Plant K, Green M, Jernigan VB, et al. Online diabetes self-management program: a randomized study. Diabetes Care 2010;33(6):1275-81.

Quinn 2008 \{published data only\}

Quinn CC, Clough SS, Minor JM, Lender D, Okafor MC, GruberBaldini A. WellDoc mobile diabetes management randomized controlled trial: change in clinical and behavioral outcomes and patient and physician satisfaction. Diabetes Technology \& Therapeutics 2008;10(3):160-8.

\section{Quinn 2011 \{published data only\}}

Quinn CC, Shardell MD, Terrin ML, Barr EA, Ballew SH, GruberBaldini AL. Cluster-randomized trial of a mobile phone personalized behavioral intervention for blood glucose control. Diabetes Care 2011;34(9):1934-42.

\section{Smith 2000 \{published data only\}}

Smith L, Weinert C. Telecommunication support for rural women with diabetes. Diabetes Educator 2000;26(4):645-55.

\section{Wise 1986 \{published data only\}}

Wise PH, Dowlatshahi DC, Farrant S, Fromson S, Meadows KA. Effect of computer-based learning on diabetes knowledge and control. Diabetes Care 1986;9(5):504-8.

\section{Yoo 2009 \{published data only\}}

Yoo HJ, Park MS, Kim TN, Yang SJ, Cho GJ, Hwng TG, et al. A ubiquitous chronic disease care system using cellular phones and the internet. Diabetic Medicine 2009;26(6):628-35.

\section{Zhou 2003 \{published data only\}}

Zhou Y, Wei GU. Computer-assisted nutrition therapy for patients with type 2 diabetes. Journal of Zhejiang University (Medical Sciences) 2003;32(3):244-8.

\section{References to studies excluded from this review}

Adams 2009 \{published data only\}

Adams SY, Crawford AG, Rimal RN, Lee JS, Janneck LM, Sciamanna CN, et al. The effects of a computer-tailored message on secondary prevention in type 2 diabetes: a randomized trial. Population Health Management 2009;12(4):197-204.

\section{Albisser 1996 \{published data only\}}

Albisser AM, Harris RI, Sakkal S, Parson ID, Chao SC, Albisser AM, et al. Diabetes intervention in the information age. Medical Informatics 1996;21(4):297-316.

Avdal 2011 \{published data only\}

Avdal E, Kizilci S, Demirel N. The effects of web-based diabetes education on diabetes care results: a randomized control study. CIN: Computers, Informatics, Nursing 2011;29(2):101-6. 
Billiard 1991 \{published data only\}

Billiard A, Rohmer V, Roques MA, Joseph MG, Suraniti S, Giraud P, et al. Telematic transmission of computerized blood glucose profiles for IDDM patients. Diabetes Care 1991;14(2):130-4.

\section{Boaz 2009 \{published data only\}}

Boaz M, Hellman K, Wainstein J, Boaz M, Hellman K, Wainstein J. An automated telemedicine system improves patientreported well-being. Diabetes Technology \& Therapeutics 2009;11(3):181-6.

\section{Bond 2007 \{published data only\}}

Bond GE, Burr R, Wolf FM, Price M, McCurry SM, Teri L, et al. The effects of a web-based intervention on the physical outcomes associated with diabetes among adults age 60 and older: a randomized trial. Diabetes Technology \& Therapeutics 2007;9(1):52-9.

\section{Bond 2010 \{published data only\}}

Bond GE, Burr RL, Wolf FM, Feldt K. The Effects of a Web-Based Intervention on Psychosocial Well-Being Among Adults Aged 60 and Older With Diabetes A Randomized Trial. Diabetes Educator 2010;36(3):446-56.

\section{Bujnowska-Fedak 2011 \{published data only\}}

Bujnowska-Fedak MM, Puchala E, Steciwko A. The impact of telehome care on health status and quality of life among patients with diabetes in a primary care setting in Poland. Telemedicine journal and e-health: the official journal of the American Telemedicine Association 2011;17(3):153-63. [PUBMED: 21375410]

\section{Carter 2011 \{published data only\}}

Carter ELN. A patient-centric, provider-assisted diabetes telehealth self-management intervention for urban minorities. Perspectives in health information management/AHIMA, American Health Information Management Association 2011;8(pp 1b):2011.

\section{Castelnuovo 2010 \{published data only\}}

Castelnuovo G, Manzoni GM, Cuzziol P, Cesa GL, Tuzzi C, Villa V, et al. TECNOB: study design of a randomized controlled trial of a multidisciplinary telecare intervention for obese patients with type-2 diabetes. BMC Public Health 2010;10:204.

\section{Cho 2006 \{published data only\}}

Cho JH, Chang SA, Kwon HS, Choi YH, Ko SH, Moon SD, et al. Long-term effect of the Internet-based glucose monitoring system on $\mathrm{HbA1c}$ reduction and glucose stability: a 30-month follow-up study for diabetes management with a ubiquitous medical care system. Diabetes Care 2006;29(12):2625-31.

\section{Cho 2009 \{published data only\}}

Cho JH, Lee HC, Lim DJ, Kwon HS, Yoon KH, Cho JH, et al. Mobile communication using a mobile phone with a glucometer for glucose control in Type 2 patients with diabetes: as effective as an Internet-based glucose monitoring system. Journal of Telemedicine \& Telecare 2009;15(2):77-82.

\section{Cleveringa 2007 \{published data only\}}

Cleveringa FGW, Gorter KJ, van den Donk M, Rutten GEH. Task delegation and computerised decision support improve cardiovascular risk for type 2 diabetes patients. A randomised controlled trial in primary care. Diabetologia 2007;50:0264.

\section{Derose 2009 \{published data only\}}

Derose SF, Nakahiro RK, Ziel FH. Automated messaging to improve compliance with diabetes test monitoring. American Journal of Managed Care 2009;15(7):425-31.

\section{Earle 2010 \{published data only\}}

Earle KA. Mobile telemonitoring for achieving tighter targets of blood pressure control in patients with complicated diabetes: A pilot study. Diabetes Technology and Therapeutics 2010;12(7):575-9.

\section{Edmonds 1998 \{published data only\}}

Edmonds M, Bauer M, Osborn S, Lutfiyya H, Mahon J, Doig G, et al. Using the Vista 350 telephone to communicate the results of home monitoring of diabetes mellitus to a central database and to provide feedback. International Journal of Medical Informatics 1998;51(2-3):117-25.

Estrada 2010 \{published data only\}

Estrada C, Salanitro A, Safford M, Curry W, Williams J, Ovalle F, et al. A cluster-randomized trial of a web-based physician intervention to improve diabetes care. Journal of Investigative Medicine 2010;58(2):512.

\section{Glasgow 1995 \{published data only\}}

Glasgow R, Toobert D, Hampson S, Noell JW. A brief officebased intervention to facilitate diabetes dietary selfmanagement. Health Education Research 1995;10(4):467-78.

Glasgow 2000 \{published data only\}

Glasgow RE, Toobert DJ, Glasgow RE, Toobert DJ. Brief, computer-assisted diabetes dietary self-management counseling: effects on behavior, physiologic outcomes, and quality of life. Medical Care 2000;38(11):1062-73.

\section{Glasgow 2002 \{published data only\}}

Glasgow RE, Toobert DJ, Hampson SE, Strycker LA. Implementation, generalization and long-term results of the "choosing well" diabetes self-management intervention. Patient Education \& Counseling 2002;48(2):115-22.

\section{Glasgow 2005a \{published data only\}}

Glasgow RE, Nutting PA, King DK, Horng MS. Improving diabetes care with interactive technology. Journal of Clinical Outcomes Management 2005;12(2):67-8.

\section{Goldberg 2006 \{published data only\}}

Goldberg HI, Hirsch IB, Hoath JI, Ralston JD, Mullen MA. Internet co-management of type 2 diabetes: A randomized controlled trial (RCT). Diabetes 2006;55:A270.

Graziano 2009 \{published data only\}

Graziano JA, Gross CR, Graziano JA, Gross CR. A randomized controlled trial of an automated telephone intervention to 
improve glycemic control in type 2 diabetes. Advances in Nursing Science 2009;32(3):E42-57.

\section{Handley 2008 \{published data only\}}

Handley MA, Shumway M, Schillinger D, Handley MA, Shumway M, Schillinger D. Cost-effectiveness of automated telephone self-management support with nurse care management among patients with diabetes. Annals of Family Medicine 2008;6(6):512-8.

\section{Harno 2006 \{published data only\}}

Harno K, Kauppinen-Makelin R, Syrjalainen J, Harno K, Kauppinen-Makelin R, Syrjalainen J. Managing diabetes care using an integrated regional e-health approach. Journal of Telemedicine \& Telecare 2006;12(Suppl 1):13-5.

\section{Holbrook 2009 \{published data only\}}

Holbrook A, Thabane L, Keshavjee K, Dolovich L, Bernstein B, Chan D, et al. Individualized electronic decision support and reminders to improve diabetes care in the community: COMPETE II randomized trial. Canadian Medical Association Journal 2009;181(1-2):37-44.

\section{Izquierdo 2010 \{published data only\}}

Izquierdo R, Lagua CT, Meyer S, Ploutz-Snyder RJ, Palmas W, Eimicke JP, et al. Telemedicine Intervention effects on waist circumference and body mass index in the IDEATel Project. Diabetes Technology \& Therapeutics 2010;12(3):213-21.

\section{Jones 2006 \{published data only\}}

Jones D, Curry W. Impact of a PDA-based diabetes electronic management system in a primary care office. American Journal of Medical Quality 2006;21(6):401-8.

\section{Kalten 2000 \{published data only\}}

Kalten MR, Ardito DA, Cimino C, Wylie-Rosett J, Kalten MR, Ardito DA, et al. A web-accessible core weight management program. Diabetes Educator 2000;26(6):929-36.

\section{Keuthage 2008 \{published data only\}}

Keuthage W. Diabetes mellitus type 2: lifestyle change in type 2 diabetics thanks to short intervention?. Gesundheitsoekonomie und Qualitaetsmanagement 2008;13(4):244-5.

\section{Kim 2005 \{published data only\}}

Kim HS, Yoo YS, Shim HS. Effects of an Internet-based intervention on plasma glucose levels in patients with type 2 diabetes. Journal of Nursing Care Quality 2005;20(4):335-40.

\section{Kim 2006 \{published data only\}}

Kim CJ, Kang DH. Utility of a web-based intervention for individuals with type 2 diabetes: the impact on physical activity levels and glycemic control. CIN: Computers, Informatics, Nursing 2006;24(6):337-45.

\section{Kim 2007 \{published data only\}}

Kim HS. A randomized controlled trial of a nurse short-message service by cellular phone for people with diabetes. International Journal of Nursing Studies 2007;44(5):687-92.
Kim 2007a \{published data only\}

Kim HS, Jeong HS. A nurse short message service by cellular phone in type-2 diabetic patients for six months. Journal of Clinical Nursing 2007;16(6):1082-7.

Kim 2008 \{published data only\}

Kim HS, Song MS. Technological intervention for obese patients with type 2 diabetes. Applied Nursing Research 2008;21(2):84-9.

\section{Kim 2010 \{published data only\}}

Kim CS, Park SY, Kang JG, Lee SJ, Ihm SH, Choi MG, et al. Insulin dose titration system in diabetes patients using a short messaging service automatically produced by a knowledge matrix. Diabetes Technology \& Therapeutics 2010;12(8):663-70.

\section{King 2006 \{published data only\}}

King DK, Estabrooks PA, Strycker LA, Toobert DJ, Bull SS, Glasgow RE, et al. Outcomes of a multifaceted physical activity regimen as part of a diabetes self-management intervention. Annals of Behavioral Medicine 2006;31(2):128-37.

\section{Kwon 2004 \{published data only\}}

Kwon HS, Cho JH, Kim HS, Song BR, Ko SH, Lee JM, et al. Establishment of blood glucose monitoring system using the internet. Diabetes Care 2004;27(2):478-83.

\section{Laffel 2007 \{published data only\}}

Laffel LMB, Hsu WC, McGill JB, Meneghini L, Volkening L K. Continued use of an integrated meter with electronic logbook maintains improvements in glycemic control beyond a randomized, controlled trial. Diabetes Technology \& Therapeutics 2007;9(3):254-65.

\section{Lee 2007 \{published data only\}}

Lee TI, Yeh YT, Liu CT, Chen PL. Development and evaluation of a patient-oriented education system for diabetes management. International Journal of Medical Informatics 2007;76(9):655-63.

Liebreich 2009 \{published data only\}

Liebreich T, Plotnikoff RC, Courneya KS, Boule N. Diabetes NetPLAY: A physical activity website and linked email counselling randomized intervention for individuals with type 2 diabetes. International Journal of Behavioral Nutrition and Physical Activity 2009;6(1):18.

\section{MacLean 2004 \{published data only\}}

MacLean CD, Littenberg B, Gagnon M, Reardon M, Turner PD, Jordan C. The Vermont Diabetes Information System (VDIS): study design and subject recruitment for a cluster randomized trial of a decision support system in a regional sample of primary care practices. Clinical Trials 2004;1(6):532-44.

\section{McMahon 2005 \{published data only\}}

McMahon GT, Gomes HE, Hickson HS, Hu TM, Levine BA, Conlin PR, et al. Web-based care management in patients with poorly controlled diabetes. Diabetes Care 2005;28(7):1624-9.

Mollon 2008 \{published data only\}

Mollon B, Holbrook AM, Keshavjee K, Troyan S, Gaebel K, Thabane $L$, et al. Automated telephone reminder messages 
can assist electronic diabetes care. Journal of Telemedicine \& Telecare 2008;14(1):32-6.

\section{Morrish 1989 \{published data only\}}

Morrish NJ, Cohen DL, Hicks B, Keen H, Morrish NJ, Cohen DL, et al. A controlled study of the effect of computer-aided analysis of home blood glucose monitoring on blood glucose control. Diabetic Medicine 1989;6(7):591-4.

\section{Noel 2004 \{published data only\}}

Noel HC, Vogel DC, Erdos JJ, Cornwall D, Levin F, Noel HC, et al. Home telehealth reduces healthcare costs. Telemedicine Journal \& E-Health 2004;10(2):170-83.

\section{Oh 2003 \{published data only\}}

Oh JA, Kim HS, Yoon KH, Choi ES. A telephone-delivered intervention to improve glycemic control in type 2 diabetic patients. Yonsei Medical Journal 2003;44(1):1-8.

Palmas 2010 \{published data only\}

Palmas W, Shea S, Starren J, Teresi JA, Ganz ML, Burton TM, et al. Medicare payments, healthcare service use, and telemedicine implementation costs in a randomized trial comparing telemedicine case management with usual care in medically underserved participants with diabetes mellitus (IDEATel). Journal of the American Medical Informatics Association 2010;17(2):196-203.

\section{Persson 2000 \{published data only\}}

Persson LG, Lindstrom K, Lingfors H. Quality improvement in primary health care using computerised journal, exemplified by a smoking cessation programme for diabetic patients. Scandinavian Journal of Primary Health Care 2000;18(4):252-3.

\section{Peters 1991 \{published data only\}}

Peters A, Rubsamen M, Jacob U, Look D, Scriba PC, Peters A, et al. Clinical evaluation of decision support system for insulindose adjustment in IDDM. Diabetes Care 1991;14(10):875-80.

\section{Piette 2000 \{published data only\}}

Piette JD, Weinberger M, McPhee SJ. The effect of automated calls with telephone nurse follow-up on patient-centered outcomes of diabetes care: a randomized, controlled trial. Medical Care 2000;38(2):218-30.

\section{Piette 2001 \{published data only\}}

Piette JD, Weinberger M, Kraemer FB, McPhee SJ. Impact of automated calls with nurse follow-up on diabetes treatment outcomes in a Department of Veterans Affairs Health Care System: a randomized controlled trial. Diabetes Care 2001;24(2):202-8.

\section{Quinn 2009 \{published data only\}}

Quinn CC, Gruber-Baldini AL, Shardell M, Weed K, Clough S, Peeples M, et al. Mobile diabetes intervention study: testing a personalized treatment/behavioral communication intervention for blood glucose control. Contemporary Clinical Trials 2009;30(4):334-46.
Ralston 2009 \{published data only\}

Ralston JD, Hirsch IB, Hoath J, Mullen M, Cheadle A, Goldberg HI. Web-based collaborative care for type 2 diabetes: a pilot randomized trial. Diabetes Care 2009;32(2):234-40.

\section{Robertson 2007 \{published data only\}}

Robertson C, Kattelmann K, Ren C. Control of type 2 diabetes mellitus using interactive internet-based support on a Northern Plains Indian reservation: a pilot study. Topics in Clinical Nutrition 2007;22(2):185-94.

\section{Rodríguez-Idígoras 2009 \{published data only\}}

Rodríguez-Idígoras MI, Sepúlveda-Muñoz J, Sánchez-GarridoEscudero R, Martínez-González JL, Escolar-Castelló JL, Paniagua-Gómez IM, et al. Telemedicine influence on the follow-up of type 2 diabetes patients. Diabetes Technology \& Therapeutics 2009;11(7):431-8.

\section{Ross 2006 \{published data only\}}

Ross SE, Haverhals LM, Main DS, Bull SS, Pratte K, Lin CT, et al. Adoption and use of an online patient portal for diabetes (Diabetes-STAR). AMIA 2006;Annual Symposium Proceedings/ AMIA Symposium.:1080.

Ryff-de 1992 \{published data only\}

Ryff-de Leche A, Engler H, Nutzi E, Berger M, Berger W, Ryff-de Leche $A$, et al. Clinical application of two computerized diabetes management systems: comparison with the log-book method. Diabetes Research 1992;19(3):97-105.

\section{Sarkar 2008 \{published data only\}}

Sarkar U, Handley MA, Gupta R, Tang A, Murphy E, Seligman HK, et al. Use of an interactive, telephone-based self-management support program to identify adverse events among ambulatory diabetes patients. Journal of General Internal Medicine 2008;23(4):459-65

\section{Schillinger 2009 \{published data only\}}

Schillinger D, Handley M, Wang F, Hammer H. Effects of selfmanagement support on structure, process, and outcomes among vulnerable patients with diabetes: a three-arm practical clinical trial. Diabetes Care 2009;32(4):559-66. [PUBMED: 19131469]

\section{Schrezenmeier 1988 \{published data only\}}

Schrezenmeier J, Müller-Haberstock S, Achterberg H, Dirting K, Stürmer W, Schulz, et al. Effect of computer-assistance on the metabolic balance of type-II diabetics under meal-related insulin therapy - a controlled multicenter study. Klinische Wochenschrift 1988;66(Suppl 13):129.

\section{Shea 2006 \{published data only\}}

Shea S, Weinstock RS, Starren J, Teresi J, Palmas W, Field L, et al. A randomized trial comparing telemedicine case management with usual care in older, ethnically diverse, medically underserved patients with diabetes mellitus. Journal of the American Medical Informatics Association 2006;13(1):40-51. 
Shea 2007 \{published data only\}

Shea S, IDEATel Consortium, Shea Steven, IDEATel Consortium. The informatics for diabetes and education telemedicine (IDEATel) project. Transactions of the American Clinical \& Climatological Association 2007;118:289-304.

\section{Shea 2009 \{published data only\}}

Shea S, Weinstock RS, Teresi JA, Palmas W, Starren J, Cimino JJ, et al. A randomized trial comparing telemedicine case management with usual care in older, ethnically diverse, medically underserved patients with diabetes mellitus: 5 year results of the IDEATel study. Journal of the American Medical Informatics Association 2009;16(4):446-57.

Sherifali 2011 \{published data only\}

Sherifali D, Greb JL, Amirthavasar G, Hunt D, Haynes RB, Harper W, et al. Effect of computer-generated tailored feedback on glycemic control in people with diabetes in the community: a randomized controlled trial. Diabetes Care 2011;34:1794-8.

\section{Shultz 1991 \{published data only\}}

Shultz EK, Bauman A, Hayward M, Rodbard D, Holzman R. Improved diabetic prognosis following telecommunication and graphical processing of diabetic data. Proceedings - the Annual Symposium on Computer Applications in Medical Care. 1991:53-7.

\section{Smith 2004 \{published data only\}}

Smith KE, Levine BA, Clement SC, Hu MJ, Alaoui A, Mun SK, et al. Impact of MyCareTeam for poorly controlled diabetes mellitus. Diabetes Technology \& Therapeutics 2004;6(6):828-35.

\section{Song 2009 \{published data only\}}

Song M, Choe MA, Kim KS, Yi MS, Lee I, Kim J, et al. An evaluation of web-based education as an alternative to group lectures for diabetes self-management. Nursing \& Health Sciences 2009;11(3):277-84.

\section{Stone 2010 \{published data only\}}

Stone RA, Rao RH, Sevick MA, Cheng C, Hough LJ, Macpherson DS, et al. Active care management supported by home telemonitoring in veterans with type 2 diabetes: the DiaTel randomized controlled trial. Diabetes Care 2010;33(3):478-85

\section{Tildesley 2011 \{published data only\}}

Tildesley HDM. Efficacy of $\mathrm{A} 1 \mathrm{C}$ reduction using internet intervention in patients with type 2 diabetes treated with insulin. Canadian Journal of Diabetes 2011;35(3):250-3.

\section{Tjam 2006 \{published data only\}}

Tjam EY, Sherifali D, Steinacher N, Hett S. Physiological outcomes of an internet disease management program vs. inperson counselling: a randomized, controlled trial. Canadian Journal of Diabetes 2006;30(4):397-405

\section{Trief 2007 \{published data only\}}

Trief PM, Teresi JA, Izquierdo R, Morin PC, Goland R, Field L, et al. Psychosocial outcomes of telemedicine case management for elderly patients with diabetes: the randomized IDEATel trial. Diabetes Care 2007:30(5):1266-8.
Tsang 2001 \{published data only\}

Tsang MW, Mok M, Kam G, Jung M, Tang A, Chan U, et al. Improvement in diabetes control with a monitoring system based on a hand-held, touch-screen electronic diary. Journal of Telemedicine \& Telecare 2001;7(1):47-50.

Turnin 1992 \{published data only\}

Turnin MC, Beddok RH, Clottes JP, Martini P, Abadie R, Buisson JC, et al. Telematic expert system Diabeto. New tool for diet self-monitoring for diabetic patients. Diabetes Care 1992;15(2):204-12.

van Bastelaar 2011 \{published data only\} van Bastelaar K, Cuijpers P, Pouwer F, Riper H, Snoek FJ, van Bastelaar Kim, et al. Development and reach of a webbased cognitive behavioural therapy programme to reduce symptoms of depression and diabetes-specific distress. Patient Education \& Counseling 2011;84(1):49-55.

van Bastelaar 2011a \{published data only\}

van Bastelaar KMP. Web-based depression treatment for type 1 and type 2 diabetic patients: A randomized, controlled trial. Diabetes Care 2011;34(2):320-5.

\section{Vespasiani 2008 \{published data only\}}

Vespasiani G, Rossi MC, Nicolucci A, Di Bartolo P, Sardu C, Bruttomesso D, et al. Comparison between the "Diabetes Interactive Diary" system and standard carbohydrate counting education: an open label, multicentre, randomised study. Diabetologia 2008;51:230.

\section{Wakefield 2011 \{published data only\}}

Wakefield BJH. Effectiveness of home telehealth in comorbid diabetes and hypertension: a randomized, controlled trial. Telemedicine journal and e-health : the official journal of the American Telemedicine Association 2011;17(4):254-61.

\section{Yeh 2006 \{published data only\}}

Yeh YT, Chiu YT, Liu CT, Wu SJ, Lee TI, Yeh YT, et al. Development and evaluation of an integrated patient-oriented education management system for diabetes. Studies in Health Technology \& Informatics 2006;122:172-5.

\section{Yoo 2008 \{published data only\}}

Yoo HJ, An HG, Park SY, Ryu OH, Kim HY, Seo JA, et al. Use of a real time continuous glucose monitoring system as a motivational device for poorly controlled type 2 diabetes. Diabetes Research \& Clinical Practice 2008;82(1):73-80.

Yoon 2008 \{published data only\}

Yoon KH, Kim HS. A short message service by cellular phone in type 2 diabetic patients for 12 months. Diabetes Research \& Clinical Practice 2008;79(2):256-61.

\section{References to studies awaiting assessment}

Faridi 2008 \{published data only\}

Faridi Z, Liberti L, Shuval K, Northrup V, Ali A, Katz D L. Evaluating the impact of mobile telephone technology on type 
2 diabetic patients' self-management: the NICHE pilot study. Journal of Evaluation in Clinical Practice 2008;14(3):465-9.

\section{Lorig 2006 \{published data only\}}

Lorig KR, Ritter PL, Laurent DD, Plant K. Internet-based chronic disease self-management: a randomized trial. Medical Care 2006;44(11):964-71. [PUBMED: 17063127]

Noh 2010 \{published data only\}

Noh JH, Cho YJ, Nam HW, Kim JH, Kim DJ, Yoo HS, et al. WebBased comprehensive information system for self-management of diabetes mellitus. Diabetes Technology \& Therapeutics 2010;12(5):333-7.

\section{Additional references}

\section{ADA 1999}

The Expert Committee on the Diagnosis and Classification of Diabetes Mellitus. Report of the Expert Committee on the diagnosis and classification of diabetes mellitus. Diabetes Care 1999;22 Suppl 1:S5-19.

\section{ADA 2008}

American Diabetes Association. Standards of medical care in diabetes - 2008. Diabetes Care 2008;31(Suppl 1):S12-54. [PUBMED: 18165335]

\section{Ajzen 2001}

Ajzen I. The theory of planned behavior. Organizational Behavior and Human Decision Processes 1991;50:179-211.

\section{Bandura 1986}

Bandura A. Social Foundations of Thought and Action: A social Cognitive Theory. Prentice- Hall, 1986.

\section{Brown 1999}

Brown S. Interventions to promote diabetes self-management: state of the science. Diabetes Education 1999;25:52-61.

\section{Campbell 2003}

Campbell R, Pound P, Pope C, Britten N, Pill R, Morgan M, et al. Evaluating meta-ethnography: a synthesis of qualitative research on lay experiences of diabetes and diabetes care. Social Science \& Medicine 2003;56(4):671-84.

\section{Carver 1982}

Carver C, Scheier M. Control theory: A useful conceptual framework for personality-social, clinical, and health psychology. Psychological Bulletin. (C) 1982 by the American Psychological Association: U Miami, FL, 1982; Vol. 92, issue 1:111-35.

\section{Collins 2004}

Collins J. Education techniques for lifelong learning: principles of adult learning. Radiographics 2004;24(5):1483-9.

\section{Corbin 1988}

Corbin J M, Strauss A. Unending Work and Care: Managing Chronic Illness at Home. Jossey-Bass, 1988.

\section{Costa 2009}

Costa BM, Fitzgerald KJ, Jones KM, Dunning AT. Effectiveness of IT-based diabetes management interventions: a review of the literature. BMC Family Practice. England: School of Nursing, Faculty of Health, Medicine, Nursing and Behavioural Sciences, Deakin University, Waterfront Campus, Geelong, 3220 Victoria, Australia.beth.costa@deakin.edu.au,2009; Vol. 10:72.

\section{DAFNE 2002}

DAFNE Study Group. Training in flexible, intensive insulin management to enable dietary freedom in people with type 1 diabetes: dose adjustment for normal eating (DAFNE) randomised controlled trial. BMJ 2002;325(7367):746.

\section{Danaei 2011}

Danaei G, Finucane MM, Lu Y, Singh GM, Cowan MJ, Paciorek CJ, et al. National, regional, and global trends in fasting plasma glucose and diabetes prevalence since 1980: systematic analysis of health examination surveys and epidemiological studies with 370 country-years and 2.7 million participants. Lancet 2011; Vol. 378 , issue $9785: 31-40$

\section{Davies 2008}

Davies MJ, Heller S, Skinner TC, Campbell MJ, Carey ME, Cradock S, et al. Effectiveness of the diabetes education and self management for ongoing and newly diagnosed (DESMOND) programme for people with newly diagnosed type 2 diabetes: cluster randomised controlled trial. BMJ 2008;336(7642):491-5.

\section{DCCT 1993}

DCCT. The effect of intensive treatment of diabetes on the development and progression of long-term complications in insulin-dependent diabetes mellitus. The Diabetes Control and Complications Trial Research Group. New England Journal of Medicine 1993;329(14):977-86.

\section{de Bruin 2009}

de Bruin M, Wolfgang V, Hospers HJ, Schaalma HP, Kok G. Standard care matters: variability in standard care quality of HAART-adherence studies: implications for the interpretation and comparison of intervention effects. Health Psychology 1999;18(2):169-76

\section{Deakin 2005}

Deakin TA, McShane CE, Cade JE, Williams R. Group based training for self-management strategies in people with type 2 diabetes mellitus. Cochrane Database of Systematic Reviews 2005, Issue 2. [DOI: 10.1002/14651858.CD003417.pub2; CD003417]

\section{Deakin 2006}

Deakin TA, Cade JE, Williams R, Greenwood DC. Structured patient education: the diabetes X-PERT Programme makes a difference. Diabetic Medicine 2006;23(9):944-54.

\section{Department of Health 2001}

Department of Health. The expert patient: a new approach to chronic disease management for the 21st century. http:// www.dh.gov.uk/en/Publicationsandstatistics/Publications/ PublicationsPolicyAndGuidance/DH_4006801 2001. 


\section{Dombrowski 2011}

Dombrowski SU, Sniehotta FF, Avenell A, Johnston M, MacLennan G, Araújo-Soares V. Identifying active ingredients in complex behavioural interventions for obese adults with obesity-related co-morbidities or additional risk factors for comorbidities: a systematic review. Health Psychology Review 2011;6(1):7-32.

\section{Duke 2009}

Duke SS, Colagiuri S, Colagiuri R. Individual patient education for people with type 2 diabetes mellitus. Cochrane Database of Systematic Reviews 2009, Issue 1. [DOI: 10.1002/14651858.CD005268.pub2; CD005268

\section{Funnell 2009}

Funnell MM, Brown TL, Childs BP, Haas LB, Hosey GM, Jensen B, et al. National standards for diabetes self-management education. Diabetes Care 2009;32(Suppl 1):S87-94.

\section{Gaede 2003}

Gaede P, Vedel P, Larsen N, Jensen GV, Parving HH, Pedersen $\mathrm{O}$. Multifactorial intervention and cardiovascular disease in patients with type 2 diabetes. New England Journal of Medicine 2003;348(5):383-93.

\section{Glasgow 2010a}

Glasgow R, Strycker L, Kurz D, Faber A, Bell H, Dickman J, et al. Recruitment for an Internet-based diabetes self-management program: scientific and ethical implications. Annals of Behavioral Medicine 2010;40(1):40-8.

\section{Griffiths 2006}

Griffiths F, Lindenmeyer A, Powell J, Lowe P, Thorogood M. Why are health care interventions delivered over the internet? A systematic review of the published literature. Journal of Medical Internet Research 2006;8(2):e10.

\section{Harris 2011}

Harris J, Felix L, Miners A, Murray E, Michie S, Ferguson E, et al. Adaptive e-learning to improve dietary behaviour: a systematic review and cost-effectiveness analysis. Health Technology Assessment (Winchester, England). England: Faculty of Epidemiology and Population Health, London School of Hygiene and Tropical Medicine, London, UK., 2011; Vol. 15, issue $37: 1-160$

\section{Higgins 2002}

Higgins JPT, Thompson SG. Quantifying heterogeneity in a meta-analysis. Statistics in Medicine 2002;21:1539-58.

\section{Higgins 2003}

Higgins JPT, Thompson SG, Deeks JJ, Altman DG. Measuring inconsistency in meta-analysis. BMJ 2003;327:557-60.

\section{Higgins 2011}

Higgins JPT, Green S (editors). Cochrane Handbook for Systematic Reviews of Interventions Version 5.1.0 [updated March 2011]. The Cochrane Collaboration, 2011. Available from www.cochrane-handbook.org.

\section{International Diabetes Federation 2011}

International Diabetes Federation. IDF 2011. http:// www.idf.org/diabetesatlas/5e/the-global-burden 2011.

\section{Jackson 2006}

Jackson CL, Bolen S, Brancati FL, Batts-Turner ML, Gary TL. A systematic review of interactive computer-assisted technology in diabetes care. Interactive information technology in diabetes care. Journal of General Internal Medicine 2006;21(2):105-10.

\section{Kennedy 2007}

Kennedy A, Reeves D, Bower P, Lee V, Middleton E, Richardson $\mathrm{G}$, et al. The effectiveness and cost effectiveness of a national lay-led self care support programme for patients with long-term conditions: a pragmatic randomised controlled trial. Journal of Epidemiology \& Community Health 2007;61(3):254-61.

\section{Liang 2011}

Liang X, Wang Q, Yang X, Cao J, Chen J, Mo X, et al. Effect of mobile phone intervention for diabetes on glycaemic control: a meta-analysis. Diabetic Medicine 2011;28(4):455-63.

\section{Liberati 2009}

Liberati A, Altman DG, Tetzlaff J, Mulrow C, Gøtzsche PC, Ioannidis JPA, et al. The PRISMA statement for reporting systematic and meta-analyses of studies that evaluate interventions: explanation and elaboration. PLoS Med 1999;6(7):1-28. [DOI: 10.1371/journal.pmed.1000100]

\section{Lorig 2001}

Lorig KR, Ritter P, Stewart AL, Sobel DS, Brown BW Jr, Bandura A, et al. Chronic disease self-management program: 2 year health status and health care utilization outcomes. Medical Care 2001;39(11):1217-23.

\section{Lorig 2003}

Lorig KR, Holman H. Self-management education: history, definition, outcomes, and mechanisms. Annals of Behavioral Medicine 2003;26(1):1-7.

\section{Medical Research Council 2008}

Medical Research Council. Developing and evaluating complex interventions: new guidance. http://www.mrc.ac.uk/Utilities/ Documentrecord/index.htm?d=MRC004871 2008.

\section{Michie 2008}

Michie S, Johnston M, Francis J, Hardeman W, Eccles M. From theory to intervention: mapping theoretically derived behavioural determinants to behaviour change techniques. Applied Psychology 2008;57(4):660-80.

\section{Michie 2009}

Michie S, Fixsen D, Grimshaw JM, Eccles MP. Specifying and reporting complex behaviour change interventions: the need for a scientific method. Implementation science: IS. England, 2009; Vol. 4:40.

\section{Michie 2009a}

Michie S, Abraham C, Whittington C, McAteer J, Gupta S. Effective techniques in healthy eating and physical activity interventions: a meta-regression. Health Psychology. (C) 
2009 by the American Psychological Association: (1)Centre for Outcomes Research and Effectiveness, University College London, United Kingdom, (2)School of Psychology, University of Sussex, Sussex, United Kingdom, (3)Department of Health, London, England, 2009; Vol. 28, issue 6:690-701.

\section{Michie 2011}

Michie S, Ashford S, Sniehotta FF, Dombrowski SU, Bishop A, French DP. A refined taxonomy of behaviour change techniques to help people change their physical activity and healthy eating behaviours: The CALO-RE taxonomy. Psychology \& Health 2011;26(11):1479-98. [PUBMED: 21678185]

\section{Michie 2012}

Michie S, Whittington C, Hamoudi Z, Zatnani F, Tober G, West R. Identification of behaviour change techniques to reduce excessive alcohol consumption. Addiction 2012;107(8):1431-40.

\section{Minet 2010}

Minet L, Moller S, Vach WR, Wagner L, Henriksen JE. Mediating the effect of self-care management intervention in type 2 diabetes: a meta-analysis of 47 randomised controlled trials. Patient Education and Counseling 2010;80(1):29-41.

\section{Munro 2007}

Munro S, Lewin S, Swart T, Volmink J. A review of health behaviour theories: how useful are these for developing interventions to promote long-term medication adherence for TB and HIV/AIDS?. BMC Public Health 2007;7:104.

\section{Murray 2005}

Murray E, Burns J, See Tai S, Lai R, Nazareth I. Interactive health communication applications for people with chronic disease. Cochrane Database of Systematic Reviews 2005, Issue 4. [DOI: 10.1002/14651858.CD004274.pub4]

\section{National Collaborating Centre 2008}

National Collaborating Centre for Chronic Conditions. Type 2 diabetes national clinical guideline for management in primary and secondary care (update). Available from: London: Royal College of Physicians.. London, 2008.

\section{Noar 2005}

Noar SM, Zimmerman RS. Health Behavior Theory and cumulative knowledge regarding health behaviors: are we moving in the right direction?. Health Education Research 2005;20(3):275-90.

\section{Noar 2008}

Noar SM. Behavioral interventions to reduce HIV-related sexual risk behavior: review and synthesis of meta-analytic evidence. AIDS \& Behavior 2008;12(3):335-53.

\section{Peters 1996}

Peters AL, Legorreta AP, Ossorio RC, Davidson MB. Quality of outpatient care provided to diabetic patients: a health maintenance organization experience. Diabetes Care 1996;19(6):601-6.

\section{Portnoy 2008}

Portnoy DB, Scott-Sheldon LA, Johnson BT, Carey MP. Computer-delivered interventions for health promotion and behavioral risk reduction: a meta-analysis of 75 randomized controlled trials, 1988-2007. Preventive Medicine 2008;47(1):3-16.

\section{Rogers 1975}

Rogers RW. A protection motivation theory of fear appeals and attitude change. Journal of Psychology 1975;91:93-114.

\section{Rosenstock 1966}

Rosenstock IM. Why people use health services. Milbank Meomorial Fund Quarterly 1966;44:94-124.

\section{Saaddine 2002}

Saaddine JB, Engelgau MM, Beckles GL, Gregg EW, Thompson TJ, Narayan KMV. A diabetes report card for the United States: quality of care in the 1990s. Annals of Internal Medicine 2002;136(8):565-74.

\section{Tate 2004}

Tate DF, Zabinski MF. Computer and Internet applications for psychological treatment: update for clinicians. Journal of Clinical Psychology 2004;60(2):209-20.

\section{Trento 2010}

Trento M, Gamba S, Gentile L, Grassi G, Miselli V, Morone G, et al. Rethink organization to improve education and outcomes (ROMEO): a multicenter randomized trial of lifestyle intervention by group care to manage type 2 diabetes. Diabetes Care 2010;33(4):745-7.

\section{UKPDS 1998}

UKPDS. Intensive blood-glucose control with sulphonylureas or insulin compared with conventional treatment and risk of complications in patients with type 2 diabetes (UKPDS 33). UK Prospective Diabetes Study (UKPDS) Group. Lancet 1998;352(9131):837-53.

\section{Wanless 2002}

Wanless D. Securing our future health: taking a long-term view - the wanless review. http://www.hm-treasury.gov.uk/ consult_wanless_final.htm 2002.

\section{WHO 1998}

Alberti KM, Zimmet PZ. Definition, diagnosis and classification of diabetes mellitus and its complications. Part I: diagnosis and classification of diabetes mellitus. Provisional report of a WHO consultation. Diabetic Medicine 1998;15:539-53.

\section{CHARACTERISTICS OF STUDIES}

Characteristics of included studies [ordered by study ID] 
Christian 2008

\begin{tabular}{ll}
\hline Methods & Study design: parallel randomised controlled trial \\
\hline Participants & Inclusion criteria: \\
1. Latin/Hispanic in ethnicity with a language preference of either English or Spanish \\
2. Aged 18 to 75 years with a diagnosis of type 2 diabetes \\
3. A BMI of 25 or greater \\
4. Uninsured, Medicaid eligible or Medicare beneficiaries. \\
Exclusion criteria: \\
1. Substance use or abuse \\
2. Severe arthritis or other medical condition limiting physical activity \\
3. Recent MI or stroke or PVD \\
4.Undergone or scheduled for gastric bypass surgery.
\end{tabular}

Interventions

\section{Number of centres: 2}

Country: USA

Setting: Outpatient clinic settings at 2 large urban community-based health centres - the Denver Health and Hospital Authority's Sandoz Westside Neighbourhood centre in Denver and the Pueblo Community Health Center Pueblo.

Outcomes

Primary end point: weight loss, expressed as mean weight loss and the fraction of participants in each group achieving a clinically meaningful weight loss defined as a $5 \%$ reduction in body weight.

Secondary end points: change in physical activity estimated in metabolic equivalent task minutes, change in energy intake, change in lipids and HbAlc levels

\begin{tabular}{|c|c|c|}
\hline Study details & \multicolumn{2}{|c|}{ Not terminated before regular end } \\
\hline \multirow[t]{3}{*}{ Publication details } & \multicolumn{2}{|l|}{ Language: English } \\
\hline & \multicolumn{2}{|c|}{$\begin{array}{l}\text { Funding: Supported by grant 5R44DK060272-3 from the US National Institute of Diabetes and Digestive } \\
\text { and Kidney Diseases to PHCC LP Pueblo Colorado }\end{array}$} \\
\hline & \multicolumn{2}{|c|}{ Publication status: Peer reviewed journal } \\
\hline Stated aim of study & \multicolumn{2}{|c|}{$\begin{array}{l}\text { "To test the effect of physicians providing brief health lifestyle counselling to patients with type } 2 \text { dia- } \\
\text { betes mellitus during usual care visits" }\end{array}$} \\
\hline Notes & \multicolumn{2}{|c|}{ Authors contacted: Blinding of outcome assessment - there was some blinding but not for all cases. } \\
\hline \multicolumn{3}{|l|}{ Risk of bias } \\
\hline Bias & Authors' judgement & Support for judgement \\
\hline $\begin{array}{l}\text { Random sequence genera- } \\
\text { tion (selection bias) }\end{array}$ & Low risk & $\begin{array}{l}\text { "Assignments to } 1 \text { of these } 2 \text { groups were based on a computer-generated ran- } \\
\text { dom number sequence" }\end{array}$ \\
\hline $\begin{array}{l}\text { Allocation concealment } \\
\text { (selection bias) }\end{array}$ & Low risk & $\begin{array}{l}\text { "Assignment was concealed to the RA by a padded envelope that also con- } \\
\text { tained a kit of baseline enrolment materials" }\end{array}$ \\
\hline $\begin{array}{l}\text { Blinding (performance } \\
\text { bias and detection bias) }\end{array}$ & High risk & $\begin{array}{l}\text { "Neither physicians nor patients could be blinded to the intervention assign- } \\
\text { ment" }\end{array}$ \\
\hline
\end{tabular}


Christian 2008 (Continued)

All outcomes
Comment: Authors contacted: no blinding for outcome assessment.

$\begin{array}{lll}\begin{array}{l}\text { Incomplete outcome data } \\ \text { (attrition bias) }\end{array} & \text { Low risk } \\ \text { All outcomes } & \begin{array}{l}\text { "Analyses were tied to a priori hypotheses. We conducted intention-to-treat } \\ \text { analyses using a "last-record-carried-forward" method in which the last avail- } \\ \text { able data from dropouts were used when analysing } 12-\text {-month data" }\end{array} \\ & \text { Follow-up rates: Intervention: } 141 / 155=91 \% . \text { Control: } 132 / 155=85 \% .\end{array}$

Selective reporting (re- Unclear risk Insufficient information to permit judgement.
porting bias)

Other bias Unclear risk

\begin{abstract}
"Ninety-eight percent of patients were taking antihyperglycaemic medications, and $51 \%$ of patients had changes in their medication regimen during the study.We were not able to determine the independent effects of changes in medication regimens on $\mathrm{HbAlc}$ levels. However, there was a significantly greater reduction in $\mathrm{HbA1c}$ level for control patients who had their dosage of antihyperglycaemic drugs increased or the type of medication changeda -0.9 reduction in $\mathrm{HbA} 1 \mathrm{c}$ level vs $\mathrm{a}-0.04$ reduction for intervention patients who also had changes in their anti-diabetes drug regimen"

Comment: The effect of the intervention on $\mathrm{HbAlc}$ is likely to be smaller than the effects of changes in anti-hyperglycaemic medication.
\end{abstract}

\begin{tabular}{ll} 
Methods & Study design: parallel randomised controlled trial \\
\hline Participants & Inclusion criteria: \\
1. Having type 1 or type 2 diabetes \\
2. aged 40 or older \\
3. Primarily responsible for one's own diabetes dietary self-management (not institutionalised).
\end{tabular}

\title{
Exclusion criteria:
}

Not stated

\begin{tabular}{ll}
\hline Interventions & Number of centres: 2 \\
& Country: USA \\
& Setting: Offices of 2 Internists \\
\hline Outcomes & $\begin{array}{l}\text { Dietary measures including the Kristal Food Habits Questionnaire and 4-day food record; BMI, choles- } \\
\text { terol and HbAlc; Patient satisfaction and cost assessment }\end{array}$ \\
\hline Study details & Not terminated before regular end \\
\hline Publication details & Language: English \\
& $\begin{array}{l}\text { Funding: Supported by grant 3DK-R01-35524 from the National Institutes of Diabetes, Digestive, and } \\
\text { Kidney Diseases } \\
\text { Publication status: Peer reviewed journal }\end{array}$ \\
\hline Stated aim of study & $\begin{array}{l}\text { The primary purpose of the study was to evaluate the effectiveness of a brief medical office-based in- } \\
\text { tervention in helping adult diabetes patients follow a healthy low-saturated fat eating plan. Secondary }\end{array}$ \\
\hline
\end{tabular}


Glasgow 1997 (Continued)

purposes were to 1) evaluate the impact of intervention on physiological (cholesterol; $\mathrm{GHb}$ ) and quality-of-life outcomes and 2) evaluate the effectiveness of the intervention for different patient subgroups.

Notes We requested further information about allocation concealment, any blinding of outcome assessors, raw means and SDs for outcome measures but received no response

\section{Risk of bias}

\begin{tabular}{lll}
\hline Bias & Authors' judgement & Support for judgement \\
\hline $\begin{array}{l}\text { Random sequence genera- } \\
\text { tion (selection bias) }\end{array}$ & Low risk & $\begin{array}{l}\text { "Two hundred and six patients were randomised within physician practice, us- } \\
\text { ing a table of random numbers, to either Usual Care or to Brief Intervention" }\end{array}$ \\
\hline $\begin{array}{l}\text { Allocation concealment } \\
\text { (selection bias) }\end{array}$ & Unclear risk & Insufficient evidence to permit judgement. \\
\hline $\begin{array}{l}\text { Blinding (performance } \\
\text { bias and detection bias) }\end{array}$ & Unclear risk & $\begin{array}{l}\text { Insufficient evidence to permit judgement. No comment on blinding of out- } \\
\text { come assessors. }\end{array}$ \\
\hline $\begin{array}{l}\text { Incomplete outcome data } \\
\text { (attrition bias) }\end{array}$ & Unclear risk & $\begin{array}{l}\text { "Sixteen percent of participants could not be contacted for the one year fol- } \\
\text { lll outcomes } \\
\text { tervention vs. control)" }\end{array}$ \\
\hline $\begin{array}{l}\text { Selective reporting (re- } \\
\text { porting bias) }\end{array}$ & Unclear risk & \begin{tabular}{l} 
Comment: No reasons for missing data. \\
\hline $\begin{array}{l}\text { Other bias } \\
\text { Insufficient evidence to permit judgement. }\end{array}$
\end{tabular} \\
\hline
\end{tabular}

Glasgow 2003

\begin{tabular}{ll} 
Methods & Study design: parallel randomised controlled trial \\
\hline Participants & Inclusion criteria: \\
& $\begin{array}{l}\text { All participants were living independently; had a telephone; read and wrote English; were diagnosed } \\
\text { with type } 2 \text { diabetes for at least } 1 \text { year, and were not planning to move out of the area during the next } \\
\text { year. Those patients taking insulin met the Welborn criteria for type } 2 \text { diabetes based on age at diagno- } \\
\text { sis, BMI, and age of insulin initiation }\end{array}$
\end{tabular}

\section{Exclusion criteria:}

Not type 2, under 40 or over 75 years, incapacitated or too ill, diagnosed less than 1 year, moving or not in area, can not read or write English and Other

Interventions

Number of centres: Patients recruited from 16 physicians at 6 different medical offices

Country: USA

\section{Setting: At home}

\section{Outcomes}

Effectiveness was evaluated by improvement from baseline to the final assessment 10 months later using multiple measures within each of three different domains: behavioural, biological, and psychosocial outcomes. 
Dietary outcomes were assessed by improvements on the Kristal Fat and Fiber Behavior (FFB) scale and the Block/ NCI Fat Screener.

Diabetes care was measured by a composite of care recommendations from the American Diabetes Association Provider Recognition Program.

Physical activity was measured by the Physical Activity Scale for the Elderly.

Biological outcomes were evaluated by changes in $\mathrm{HbA1C}$ and lipid ratios

Psychosocial outcomes were measured by the Diabetes Support Scale and the Center for Epidemiologic Studies-Depression scale (CES-D)

Delivery of intervention components and participant usage of the website

\begin{tabular}{ll}
\hline Study details & Not terminated before regular end \\
\hline Publication details & Language: English \\
& $\begin{array}{l}\text { Funding: Supported in part by Grant RO1-DK-51581 from the National Institute of Diabetes, Digestive, } \\
\text { and Kidney Diseases }\end{array}$ \\
& Publication status: Peer reviewed journal \\
\hline Stated aim of study & $\begin{array}{l}\text { "To report on the longer-term implementation across interventionists, on program usage over time and } \\
\text { across conditions, on 10-month follow-up results on behavioral, biologic, and psychosocial outcomes, } \\
\text { and on generalization of results across patients from the different clinics participating in the study" }\end{array}$ \\
\hline Notes & $\begin{array}{l}\text { We contacted the authors requesting more information on: Method of sequence generation and alloca- } \\
\text { tion concealment, any blinding of participants or assessors, need to know numbers in each condition, } \\
\text { details of participants. Contacted author, no response. }\end{array}$ \\
\hline
\end{tabular}

\section{Risk of bias}

Bias Authors' judgement Support for judgement

Random sequence genera- Unclear risk Insufficient evidence to permit judgement.
tion (selection bias)
tion (selection bias)

Allocation concealment $\quad$ Unclear risk Insufficient evidence to permit judgement.
(selection bias)

Blinding (performance Unclear risk Insufficient evidence to permit judgement.

bias and detection bias)

All outcomes

\begin{tabular}{ll}
\hline $\begin{array}{l}\text { Incomplete outcome data } \\
\text { (attrition bias) }\end{array}$ & Unclear risk
\end{tabular}

All outcomes cluded in the trial.

Selective reporting (re- Unclear risk $\quad$ Insufficient evidence to permit judgement.
porting bias)

Other bias Unclear risk Control arm received automated dietary change goals.

\section{Glasgow 2005}

Methods Study design: cluster parallel randomised controlled trial


Glasgow 2005 (Continued)

Participants

Inclusion criteria: the only inclusion criteria were age $>$ or $=25$ years, ability to read English, and type 2 diabetes, confirmed using the Welborn criteria

Exclusion criteria: none stated

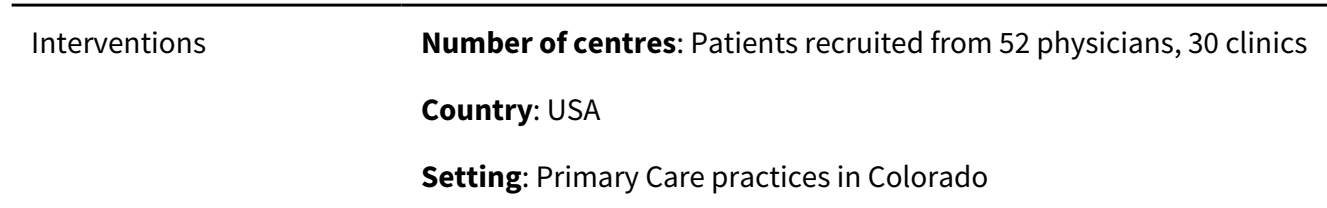

Outcomes
$\begin{aligned} & \text { Two primary outcomes: number of recommended laboratory screenings and recommended pa- } \\ & \text { tient-centred care activities completed from the National Committee on Quality Assurance/American } \\ & \text { Diabetes Association Provider Recognition Program (PRP). }\end{aligned}$
$\begin{aligned} & \text { Secondary outcomes were evaluated using the Problem Areas in Diabetes } 2 \text { quality of life scale, lipid } \\ & \text { and HbAlc levels, and the Patient Health Questionnaire-9 depression scale. }\end{aligned}$

\begin{tabular}{ll}
\hline Study details & Not terminated before regular end \\
\hline Publication details & Language: English \\
& Publication status: Peer reviewed journal \\
\hline Stated aim of study & $\begin{array}{l}\text { To determine if a patient-centred, computer-assisted diabetes care intervention increased perceived } \\
\text { autonomy support, perceived competence (from self-determination theory), and if these constructs } \\
\text { mediated the effect of the intervention on ADA/NCQA recommended diabetes care outcomes. }\end{array}$ \\
\hline Notes &
\end{tabular}

\section{Risk of bias}

\begin{tabular}{|c|c|c|}
\hline Bias & Authors' judgement & Support for judgement \\
\hline $\begin{array}{l}\text { Random sequence genera- } \\
\text { tion (selection bias) }\end{array}$ & Unclear risk & $\begin{array}{l}\text { "Randomization was conducted by the project statistician..." } \\
\text { Comment: No details about method of randomisation were provided. }\end{array}$ \\
\hline $\begin{array}{l}\text { Allocation concealment } \\
\text { (selection bias) }\end{array}$ & Low risk & $\begin{array}{l}\text { "Randomization was conducted by the project statistician, who then notified } \\
\text { research staff of condition assignment". Although the study was not blinded, } \\
\text { research staff would not be at risk of introducing selection bias as allocation } \\
\text { was done by the statistician. }\end{array}$ \\
\hline $\begin{array}{l}\text { Blinding (performance } \\
\text { bias and detection bias) } \\
\text { All outcomes }\end{array}$ & High risk & $\begin{array}{l}\text { "Randomization was conducted by the project statistician, who then notified } \\
\text { research staff of condition assignment". Research staff were aware of alloca- } \\
\text { tion. }\end{array}$ \\
\hline $\begin{array}{l}\text { Incomplete outcome data } \\
\text { (attrition bias) } \\
\text { All outcomes }\end{array}$ & Unclear risk & $\begin{array}{l}\text { Insufficient evidence to permit judgement. Follow-up rates: Intervention: } \\
379 / 469=81 \% \text {. Control: } 354 / 417=85 \% \text {. }\end{array}$ \\
\hline $\begin{array}{l}\text { Selective reporting (re- } \\
\text { porting bias) }\end{array}$ & Unclear risk & Insufficient evidence to permit judgement. \\
\hline Other bias & Low risk & Nothing detected \\
\hline
\end{tabular}




\begin{tabular}{|c|c|}
\hline Methods & Study design: parallel randomised controlled trial \\
\hline \multirow[t]{4}{*}{ Participants } & Inclusion criteria: \\
\hline & $\begin{array}{l}\text { Eligible participants were at least } 25 \text { years old, diagnosed with type } 2 \text { diabetes for at least } 6 \text { months, } \\
\text { and able to read and write in English. }\end{array}$ \\
\hline & Exclusion criteria: \\
\hline & $\begin{array}{l}\text { Physicians had the option of excluding patients for whom they felt the intervention would not be ap- } \\
\text { propriate. }\end{array}$ \\
\hline
\end{tabular}

Interventions

Number of centres:multiple: Adults diagnosed with type 2 diabetes residing in the Denver, Colorado metropolitan area recruited from lists provided by 42 participating physicians ( $20 \%$ from mixed payer settings, and the remainder employed by Kaiser Permanente Colorado)

Country: USA

Setting: The primary intervention was conducted at a location external to the participant's primary care setting. This was typically a central clinic or medical office not too distant from the participant's home. including both mixed-payer, fee for-service and managed-care offices

\begin{tabular}{ll}
\hline Outcomes & $\begin{array}{l}\text { Outcomes were changes in dietary behaviours (fat and fruit/vegetable intake), haemoglobin A1c } \\
\text { (HbA1c), lipids, weight, quality of life, and depression }\end{array}$ \\
\hline Study details & Not terminated before regular end \\
\hline Publication details & Language: English \\
& $\begin{array}{l}\text { Funding: National Institute of Diabetes \& Digestive \& Kidney Diseases, Grant \#DK35524. Copic In- } \\
\text { surance Company introduced the project to private physician offices }\end{array}$ \\
& Publication status: Peer reviewed journal \\
\hline Stated aim of study & $\begin{array}{l}\text { The primary purposes of this article are to report on (1) the short-term (2-month) dietary, biological } \\
\text { and quality-of-life outcomes from tailored self-management, (2) the implementation and feasibility of } \\
\text { the programme, and (3) implications for broader dissemination }\end{array}$ \\
\hline Notes & $\begin{array}{l}\text { Further information needed: Details of sequence generation and allocation concealment, any blinding, } \\
\text { Increase in fruit and vegetable score given in text (para } 1 \text { pg 34) does not correspond with the table for } \\
\text { intervention. Contacted author, no response. }\end{array}$ \\
\hline
\end{tabular}

\section{Risk of bias}

\begin{tabular}{|c|c|c|}
\hline Bias & Authors' judgement & Support for judgement \\
\hline $\begin{array}{l}\text { Random sequence genera- } \\
\text { tion (selection bias) }\end{array}$ & Unclear risk & Insufficient evidence to permit judgement. \\
\hline $\begin{array}{l}\text { Allocation concealment } \\
\text { (selection bias) }\end{array}$ & Unclear risk & Insufficient evidence to permit judgement. \\
\hline $\begin{array}{l}\text { Blinding (performance } \\
\text { bias and detection bias) } \\
\text { All outcomes }\end{array}$ & Unclear risk & Insufficient evidence to permit judgement. \\
\hline $\begin{array}{l}\text { Incomplete outcome data } \\
\text { (attrition bias) } \\
\text { All outcomes }\end{array}$ & Low risk & $\begin{array}{l}\text { "Attrition was modest ( } 10 \% \text { ) by the } 2 \text {-month assessment, and not different } \\
\text { across conditions. Because of this low attrition rate, we used complete-case }\end{array}$ \\
\hline
\end{tabular}


Glasgow 2006 (Continued)

analyses in the present investigation, but intention-to-treat analyses with baseline values substituted for missing cases produced identical conclusions"

\begin{tabular}{lll}
\hline $\begin{array}{l}\text { Selective reporting (re- } \\
\text { porting bias) }\end{array}$ & Unclear risk & Insufficient evidence to permit judgement. \\
\hline Other bias & Unclear risk & $\begin{array}{l}\text { Physicians had the option of excluding patients for whom they felt the inter- } \\
\text { vention would not be appropriate. }\end{array}$ \\
\hline
\end{tabular}

Glasgow 2010

\begin{tabular}{ll}
\hline Methods & Study design: randomised controlled trial \\
\hline Participants & Inclusion criteria: \\
& $25-75$ years of age, diagnosis of type 2 diabetes, body mass \\
& index (BMI) of $25 \mathrm{~kg} / \mathrm{m} 2$ or greater, and at least one other risk \\
& factor for heart disease (hypertension, low-density lipoprotein $[\mathrm{LDL}]>100$ or on a lipid-lowering agent, \\
& haemoglobin Alc $>7 \%$, or being a current smoker). Additional inclusion criteria were access to a tele- \\
& phone and at least biweekly access to the Internet, ability to read and write in English or Spanish, and \\
& to perform mild to moderate PA
\end{tabular}

\section{Exclusion criteria:}

1. Sharing same household as other participants 2. Physicians not approved 3. Do not speak either English or Spanish

Interventions

Number of centres:The study was conducted in five primary care clinics within Kaiser Permanente Colorado (KPCO).

Country: USA

Setting: Clinics were selected based on variability in size, location, and socioeconomic status of neighbourhood, and to maximise percentage of Latino patients.

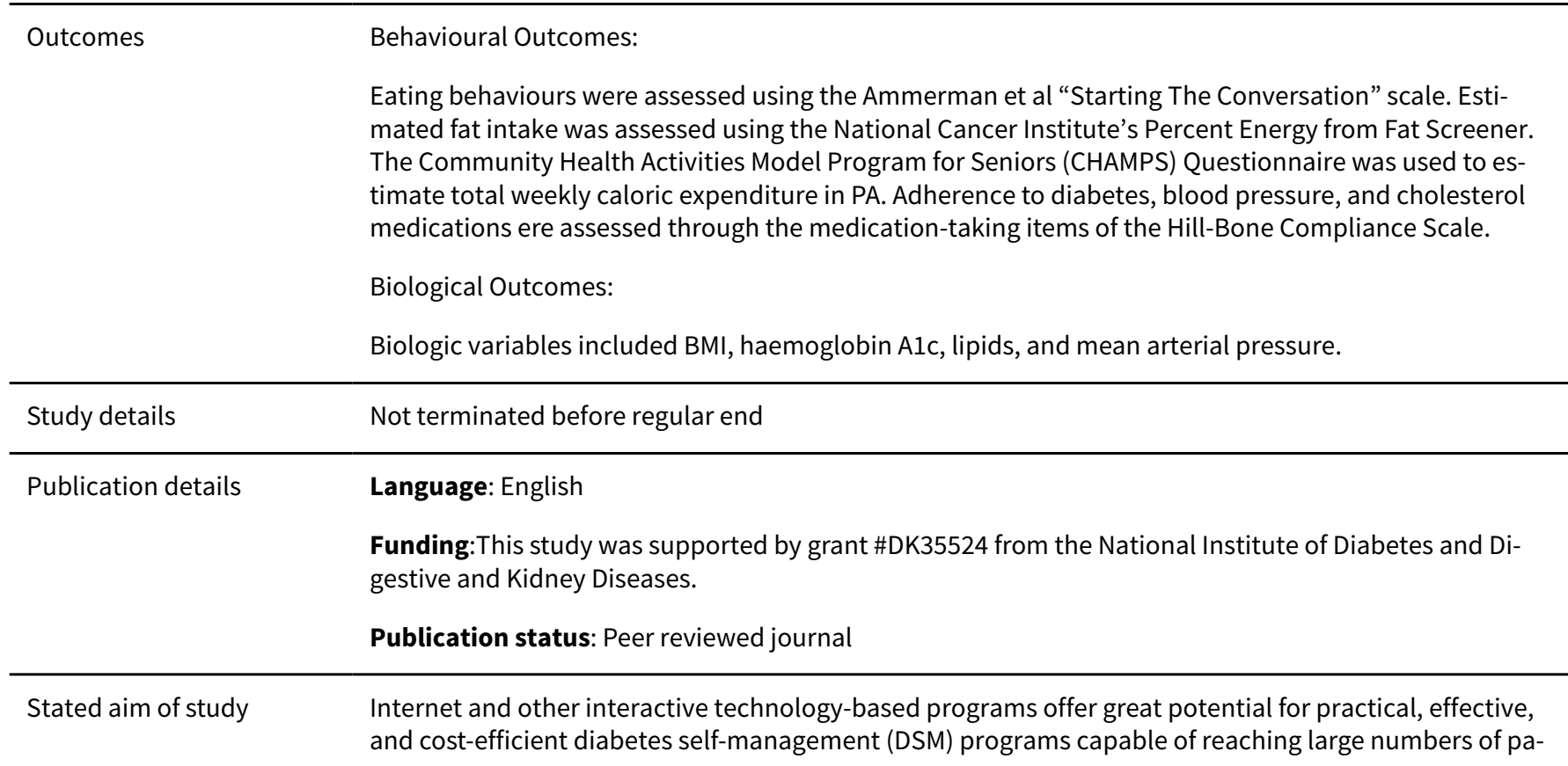


tients. This study evaluated minimal and moderate support versions of an Internet-based diabetes selfmanagement program, compared to an enhanced usual care condition.

The purposes of this paper were to (a) evaluate the feasibility of an Internet-based DSM program (MyPath/Mi Camino) using the RE-AIM (Reach, Effectiveness, Adoption, Implementation, Maintenance) model19 (www.re-aim.org); (b) present the 4-month behavioural and biological outcomes from a practical randomised trial; and (c) experimentally investigate the incremental effects of adding support to a minimal-contact version of the Internet-based program.

\section{Notes}

\section{Risk of bias}

\begin{tabular}{|c|c|c|}
\hline Bias & Authors' judgement & Support for judgement \\
\hline $\begin{array}{l}\text { Random sequence genera- } \\
\text { tion (selection bias) }\end{array}$ & Low risk & $\begin{array}{l}\text { "Participants were individually randomised via a computer program devel- } \\
\text { oped by our computer programmer and statistician" }\end{array}$ \\
\hline $\begin{array}{l}\text { Allocation concealment } \\
\text { (selection bias) }\end{array}$ & Unclear risk & Insufficient evidence to permit judgement. \\
\hline $\begin{array}{l}\text { Blinding (performance } \\
\text { bias and detection bias) } \\
\text { All outcomes }\end{array}$ & Unclear risk & $\begin{array}{l}\text { Insufficient evidence to permit judgement but the study design makes it un- } \\
\text { likely that participants or staff were blinded. }\end{array}$ \\
\hline $\begin{array}{l}\text { Incomplete outcome data } \\
\text { (attrition bias) } \\
\text { All outcomes }\end{array}$ & Low risk & $\begin{array}{l}\text { Intention-to-treat analysis done. Follow-up rates: Intervention: } 130 / 169=77 \% \text {. } \\
\text { Control: } 115 / 132=87 \% \text {. Significant difference in retention between groups. }\end{array}$ \\
\hline $\begin{array}{l}\text { Selective reporting (re- } \\
\text { porting bias) }\end{array}$ & Unclear risk & Insufficient evidence to permit judgement. \\
\hline Other bias & Low risk & Nothing detected \\
\hline
\end{tabular}

Leu 2005

\begin{tabular}{ll}
\hline Methods & Study design: parallel randomised controlled trial \\
\hline Participants & $\begin{array}{l}\text { Inclusion criteria: } \\
\text { Patients with } \mathrm{HbA} 1 \mathrm{c} \text { values between } 8.0 \% \text { and } 9.4 \% \text { at the time of recruitment, with either type } 1 \text { or } \\
\text { type } 2 \text { diabetes. }\end{array}$
\end{tabular}

\section{Exclusion criteria:}

Three participants were found to be ineligible (two had pacemakers, and one was trying to conceive).

Interventions

Number of centres: 9 clinics, 20 primary care providers and two endocrinologists.

\section{Country: USA}

Setting: University of Washington Physician's Network (UWPN) clinics located in Western Washington. This is a group of nine neighbourhood clinics, of which Belltown (near Downtown Seattle), Auburn, Federal Way, Factoria, and Kent/Des Moines participated (20 primary care providers and two endocrinologists). 
Leu 2005 (Continued)

Blood pressure was a secondary outcome measure. Patients' attitudes as self-reported by survey were another secondary outcome measure.

\begin{tabular}{ll}
\hline Study details & Not terminated before regular end. \\
\hline Publication details & Language: English \\
& $\begin{array}{l}\text { Funding: American Diabetes Association (Medical Scholars Award), by the Warren G. Magnuson Insti- } \\
\text { tute for Biomedical Research and Health Professional Training (Magnuson Scholarship), and by an Al- } \\
\text { pha Omega Alpha Student Research Fellowship } \\
\\
\text { Publication status: Peer reviewed journal }\end{array}$ \\
\hline Stated aim of study & $\begin{array}{l}\text { This randomised, controlled study tested the effect of using a wireless two-way pager-based automat- } \\
\text { ed messaging system to improve diabetes control through facilitated self-management. }\end{array}$ \\
\hline Notes & $\begin{array}{l}\text { Further information needed: details of excluded cases, control conditions, definition of hypertension, } \\
\text { method of sequence generation. Tried to contact author, unable to get contact details. }\end{array}$ \\
\hline
\end{tabular}

\section{Risk of bias}

\begin{tabular}{|c|c|c|}
\hline Bias & Authors' judgement & Support for judgement \\
\hline $\begin{array}{l}\text { Random sequence genera- } \\
\text { tion (selection bias) }\end{array}$ & Low risk & $\begin{array}{l}\text { "Prior to enrolment, an Excel spreadsheet was created that randomised } 60 \text { pa- } \\
\text { tients in groups of six. A stack of envelopes was created, containing the results } \\
\text { of the randomizations. The allocation sequence was generated by the investi- } \\
\text { gator" }\end{array}$ \\
\hline $\begin{array}{l}\text { Allocation concealment } \\
\text { (selection bias) }\end{array}$ & Low risk & $\begin{array}{l}\text { "This collection of envelopes was randomly "cut" in the middle, and the en- } \\
\text { velopes were numbered from } 1 \text { to } 60 \text {. The sequence was concealed until the } \\
\text { interventions were assigned at enrolment" }\end{array}$ \\
\hline $\begin{array}{l}\text { Blinding (performance } \\
\text { bias and detection bias) } \\
\text { All outcomes }\end{array}$ & High risk & "There was no blinding in the study due to the nature of the intervention" \\
\hline $\begin{array}{l}\text { Incomplete outcome data } \\
\text { (attrition bias) } \\
\text { All outcomes }\end{array}$ & Unclear risk & $\begin{array}{l}\text { Reporting of cases of attrition does not provide details about all the partici- } \\
\text { pants excluded in the results section. } 18 \% \text { dropout rate in control and inter- } \\
\text { vention arms. }\end{array}$ \\
\hline $\begin{array}{l}\text { Selective reporting (re- } \\
\text { porting bias) }\end{array}$ & Unclear risk & Insufficient evidence to permit judgement. \\
\hline Other bias & Low risk & Nothing detected \\
\hline
\end{tabular}

\section{Lim 2011}

\begin{tabular}{ll}
\hline Methods & Study design: block randomised controlled trial \\
\hline Participants & Inclusion criteria: \\
Age $>=60$. All enrolled participants had been diagnosed with type 2 diabetes for at least 1 year, and \\
their A1C level was $6.5 \%-10.5 \%$ \\
Exclusion criteria: \\
The study excluded patients with severe diabetes complications (e.g., diabetic foot or severe diabet- \\
ic retinopathy), liver dysfunction (aspartate aminotransferase or alanine aminotransferase $>2.5$ times
\end{tabular}


Lim 2011 (Continued)

the reference level), or renal dysfunction (serum creatinine $>132 \mu \mathrm{mol} / \mathrm{L}[1.7 \mathrm{mg} / \mathrm{dL}]$ ), or other medical problems that could affect study results or trial participation. The study enrolment excluded patients without a text message function on their cellular phone or who were unable to use text messages for any reason.

Number of centres: 1.
Patients were recruited from the outpatient clinic of the Seoul National University Bundang Hospital
(SNUBH). Participants used the intervention from home.

Outcomes The primary end point of the study was the proportion of patients achieving an A1C level of $<7 \%$ without hypoglycaemia at 6 months.

Secondary outcomes included weight, BMI, serum lipids, frequency of blood glucose monitoring, and fasting/post-prandial blood glucose.

\begin{tabular}{ll}
\hline Study details & Not terminated before regular end \\
\hline Publication details & Language: English \\
& $\begin{array}{l}\text { Funding: "This study was supported by a grant of the Korea Healthcare technology R\&D Project, Min- } \\
\text { istry for Health, Welfare \& Family Affairs, Republic of Korea (A090001), a research grant (02-2008-036) } \\
\text { from the SNUBH, and the Korea Science and Engineering Foundation grants funded by the Ministry of } \\
\text { Science and Technology (M10642140004-06N4214-00410)" } \\
\text { Publication status: Peer reviewed journal }\end{array}$ \\
\hline Stated aim of study & $\begin{array}{l}\text { "To improve quality and efficiency of care for elderly patients with type 2 diabetes, we introduced el- } \\
\text { derly-friendly strategies to the clinical decision support system (CDSS)-based ubiquitous healthcare (u- } \\
\text { healthcare) service, which is an individualized health management system using advanced medical in- } \\
\text { formation technology" }\end{array}$ \\
\hline Notes & Details of randomisations - Contacted author, no response. \\
\hline
\end{tabular}

Risk of bias

\begin{tabular}{lll}
\hline Bias & Authors' judgement & Support for judgement \\
\hline $\begin{array}{l}\text { Random sequence genera- } \\
\text { tion (selection bias) }\end{array}$ & Unclear risk & "Block randomizations was used to assign each patient" \\
\hline $\begin{array}{l}\text { Allocation concealment } \\
\text { (selection bias) }\end{array}$ & Unclear risk & Insufficient evidence to permit judgement. \\
\hline $\begin{array}{l}\text { Blinding (performance } \\
\text { bias and detection bias) }\end{array}$ & High risk & No blinding of participants possible with this study design. No information \\
$\begin{array}{l}\text { All outcomes } \\
\text { provided about blinding of assessors. }\end{array}$ \\
\hline $\begin{array}{l}\text { Incomplete outcome data } \\
\begin{array}{l}\text { (attrition bias) } \\
\text { All outcomes }\end{array}\end{array}$ & Low risk & $\begin{array}{l}\text { Dropout rates were low. } 2 / 51 \text { (3.9\%) dropout rate in the intervention group and } \\
4 / 52 ~(7.3 \%) \text { dropout rate in the control group. No imputation for missing data. }\end{array}$ \\
\hline $\begin{array}{l}\text { Selective reporting (re- } \\
\text { porting bias) }\end{array}$ & Unclear risk & Insufficient evidence to permit judgement. \\
\hline \begin{tabular}{l} 
Other bias \\
\hline
\end{tabular} & Low risk & Nothing detected \\
\hline
\end{tabular}




\begin{tabular}{|c|c|}
\hline Methods & Study design: parallel randomised controlled trial \\
\hline \multirow[t]{4}{*}{ Participants } & Inclusion criteria: \\
\hline & $\begin{array}{l}\text { People with } \mathrm{T} 1 \text { and } \mathrm{T} 2 \text { diabetes at the Lismore base hospital diabetic clinic, diagnosed between } 2 \\
\text { months and } 10 \text { years prior to this study. }\end{array}$ \\
\hline & Exclusion criteria: \\
\hline & None stated \\
\hline \multirow[t]{3}{*}{ Interventions } & Number of centres: 1 \\
\hline & Country: Australia \\
\hline & Setting: Community health centre office - Diabetes clinic at the Lismore base hospital \\
\hline Outcomes & Knowledge levels measured by multiple choice tests and glycated haemoglobin levels \\
\hline Study details & Not terminated before regular end \\
\hline \multirow[t]{3}{*}{ Publication details } & Language: English \\
\hline & Funding: IRG grant from the University of New England, Northern Rivers, New South Wales \\
\hline & Publication status: Peer reviewed journal \\
\hline Stated aim of study & $\begin{array}{l}\text { An evaluation study of the CAL program was conducted to test the following propositions: - partici- } \\
\text { pants who complete the CAL program will achieve a greater increase in their knowledge of diabetes } \\
\text { mellitus management than participants who complete a conventional diabetes program. - The CAL } \\
\text { program will motivate patients to achieve greater improvements in their glucose levels than a conven- } \\
\text { tional diabetes program. - It is feasible to develop a CAL diabetes education program for home comput- } \\
\text { ers. }\end{array}$ \\
\hline Notes & $\begin{array}{l}\text { Further information needed: details of allocation and reasons for attrition. Unable to find current con- } \\
\text { tact details for author. }\end{array}$ \\
\hline
\end{tabular}

\section{Risk of bias}

\begin{tabular}{lll}
\hline Bias & Authors' judgement & Support for judgement \\
\hline $\begin{array}{l}\text { Random sequence genera- } \\
\text { tion (selection bias) }\end{array}$ & Unclear risk & "Participants were randomly assigned" \\
& Comment: No details given. Insufficient evidence to permit judgement. \\
\hline $\begin{array}{l}\text { Allocation concealment } \\
\text { (selection bias) }\end{array}$ & Unclear risk & Insufficient evidence to permit judgement. \\
\hline $\begin{array}{l}\text { Blinding (performance } \\
\text { bias and detection bias) } \\
\text { All outcomes }\end{array}$ & High risk & No blinding of participants possible with this study design. No information \\
\hline \begin{tabular}{l} 
Incomplete outcome data \\
(attrition bias) \\
$\begin{array}{l}\text { All outcomes } \\
\text { provided about blinding of assessors. }\end{array}$ \\
\hline $\begin{array}{l}\text { Selective reporting (re- } \\
\text { porting bias) }\end{array}$
\end{tabular} Unclear risk & $\begin{array}{l}\text { Insufficient evidence to permit judgement. } \\
\text { No details provided about participants who did not complete the study. All pa- } \\
\text { tients who dropped out were from the control arm. }\end{array}$ \\
\hline \hline
\end{tabular}


Lo 1996 (Continued)
Other bias
Low risk
Nothing detected

Lorig 2010

Study design: parallel randomised controlled trial for 6 months.
After that a subset of American Indians/native Alaskans were part of a wait-list control trial and were
given the opportunity to use the intervention.

Inclusion criteria:
Participants
diabetes, and had access to the Internet. Recruitment was largely via the Internet, although print and
broadcast media were also utilised.
Specific recruitment of AI/AN minorities into a separate subgroup.

\section{Exclusion criteria:}

None stated

\begin{tabular}{|c|c|}
\hline Interventions & $\begin{array}{l}\text { Number of centres: Online trial } \\
\text { Country: USA } \\
\text { Setting: Internet-based - all consents and questionnaires administered online and patients took } \\
\text { HbA1C themselves with a postal blood-letting kit }\end{array}$ \\
\hline Outcomes & $\begin{array}{l}\text { The primary outcome measure was A1C, measured using capillary blood obtained with self-adminis- } \\
\text { tered BIOSAFE kits. } \\
\text { Secondary outcomes: } \\
\text { Health-related distress was measured by the health distress scale } \\
\text { The activity limitations scale, which measures the impact of disease on role activities such as recre- } \\
\text { ation and chores } \\
\text { Depression was measured by the Patient Health Questionaire (PHQ)-9 } \\
\text { A physical activities scale measured total minutes per week of aerobic exercise } \\
\text { Tertiary outcomes: } \\
\text { Tertiary measures included the } 13 \text { - item short-form Patient Activation Measure (PAM) and diabetes self- } \\
\text { efficacy }\end{array}$ \\
\hline Study details & Not terminated before regular end \\
\hline Publication details & $\begin{array}{l}\text { Language: English } \\
\text { Funding: The study was supported by National Institutes of Health Grant 1R18DK065729 and Robert } \\
\text { Wood Johnson Foundation Grant } 096223 . \\
\text { Publication status: Peer reviewed journal }\end{array}$ \\
\hline Stated aim of study & $\begin{array}{l}\text { "We hypothesized that participants in the IDSMP, compared with usual-care control subjects, would } \\
\text { demonstrate 1) reduced A1C at } 6 \text { and } 18 \text { months, 2) have fewer symptoms, 3) have increased exercise, } \\
\text { and 4) have improved self-efficacy and patient activation.We also hypothesized that participants ran- } \\
\text { domised to a follow-up list serve, peer-support group would have better } 18 \text {-month outcomes than par- } \\
\text { ticipants receiving no follow-up" }\end{array}$ \\
\hline
\end{tabular}


Lorig 2010 (Continued)

Notes $\quad$ Further information required: details of allocation concealment. Contacted author, no response.

\section{Risk of bias}

\begin{tabular}{|c|c|c|}
\hline Bias & Authors' judgement & Support for judgement \\
\hline $\begin{array}{l}\text { Random sequence genera- } \\
\text { tion (selection bias) }\end{array}$ & Low risk & Random numbers table. \\
\hline $\begin{array}{l}\text { Allocation concealment } \\
\text { (selection bias) }\end{array}$ & Unclear risk & Insufficient evidence to permit judgement. \\
\hline $\begin{array}{l}\text { Blinding (performance } \\
\text { bias and detection bias) } \\
\text { All outcomes }\end{array}$ & High risk & $\begin{array}{l}\text { It would not be possible to blind participants in this study design. Collection of } \\
\text { data was self-reported so blinding of "assessors" was not necessary; however } \\
\text { patients were not blinded and were responsible for data collection so the risk } \\
\text { of bias cannot be described as low. }\end{array}$ \\
\hline \multirow{2}{*}{$\begin{array}{l}\text { Incomplete outcome data } \\
\text { (attrition bias) } \\
\text { All outcomes }\end{array}$} & Low risk & $\begin{array}{l}\text { "When intent-to-treat analyses were used, PAM and self-efficacy remained sig- } \\
\text { nificant, while the P value for A1C increased to } 0.060 \text { " }\end{array}$ \\
\hline & & $\begin{array}{l}\text { Comment: Intention-to-treat analysis used. Follow-up rates: Intervention: } \\
395 / 491=80 \% \text {. Control: } 238 / 270=88 \% \text {. }\end{array}$ \\
\hline $\begin{array}{l}\text { Selective reporting (re- } \\
\text { porting bias) }\end{array}$ & Unclear risk & Insufficient evidence to permit judgement. \\
\hline Other bias & Low risk & Nothing detected \\
\hline
\end{tabular}

Quinn 2008

\begin{tabular}{ll}
\hline Methods & Study design: parallel randomised controlled trial \\
\hline Participants & Inclusion criteria: \\
& $\begin{array}{l}\text { The study enrolled patients } 18-70 \text { years old who had a diagnosis of type } 2 \text { diabetes for at least } 6 \\
\text { months. Study patients were required to have an A1c } 7.5 \% \text { and to have been on a stable diabetes thera- } \\
\text { peutic regimen for } 3 \text { months prior to study enrolment. }\end{array}$
\end{tabular}

\section{Exclusion criteria:}

None stated

\begin{tabular}{ll}
\hline Interventions & Number of centres: 3 \\
& Country: USA \\
& Setting: One community endocrinology and two community primary care practices \\
\hline Outcomes & Summary of Diabetes Self-Care Activities (SDSCA) questionnaire and HbA1c \\
\hline Study details & Not terminated before regular end \\
\hline Publication details & Language: English \\
& Funding: Study was supported by LifeScan, Inc. and Nokia, Inc. \\
& Publication status: Peer reviewed journal \\
\hline
\end{tabular}


Quinn 2008 (Continued)

Stated aim of study The primary study aim was to assess the impact on A1c of a cell phone-based diabetes management software system used with web-based data analytics and therapy optimisation tools. Secondary aims examined healthcare provider (HCP) adherence to prescribing guidelines and assessed HCPs' adoption of the technology.

\begin{tabular}{ll}
\hline Notes & $\begin{array}{l}\text { Further information needed: details of sequence generation and allocation concealment. Contacted } \\
\text { author, no response. }\end{array}$
\end{tabular}

\section{Risk of bias}

Bias Authors' judgement Support for judgement

Random sequence genera- Unclear risk tion (selection bias)

"Eligible patients gave consent and were randomised to either the control or intervention group"

Comment: Insufficient evidence to permit judgement.

Allocation concealment Unclear risk Insufficient evidence to permit judgement.
(selection bias)

\begin{tabular}{ll}
\hline Blinding (performance & High risk
\end{tabular}

All outcomes

\begin{tabular}{ll}
\hline $\begin{array}{l}\text { Incomplete outcome data } \\
\text { (attrition bias) }\end{array}$ & "Characteristics for drop-out subjects were not different from the remaining \\
study subjects"
\end{tabular}

All outcomes

Comment: No details given about reasons for dropping out of study. Insuffi-
cient evidence to permit judgement.

Follow-up rates: Intervention: $13 / 15=87 \%$. Control: $13 / 15=87 \%$.

\begin{tabular}{lll}
\hline $\begin{array}{l}\text { Selective reporting (re- } \\
\text { porting bias) }\end{array}$ & Unclear risk & Insufficient evidence to permit judgement. \\
\hline Other bias & "A convenience sample of 30 patients with type 2 diabetes was recruited" \\
& $\begin{array}{l}\text { Comment: Small convenience sample - insufficient detail about local popula- } \\
\text { tion to determine the consequences of this. }\end{array}$ \\
& $\begin{array}{l}\text { Control group was expected to be quite pro-active: "They were asked to fax or } \\
\text { call in their BG logbooks every } 2 \text { weeks to their HCPs until their BG levels were } \\
\text { stabilized in the target ranges or until their HCPs changed testing frequency" }\end{array}$ \\
\hline
\end{tabular}

Quinn 2011

\begin{tabular}{ll}
\hline Methods & Study design: cluster-randomised controlled trial \\
\hline Participants & Inclusion criteria: \\
& Physician diagnosis of type 2 diabetes for $\geq 6$ months; \\
& Glycated haemoglobin $\geq 7.5 \%$ within 3 months; \\
& Age $18-64$ years. \\
& Exclusion criteria: \\
& Medicare or Medicaid beneficiaries; \\
Uninsured;
\end{tabular}


Quinn 2011 (Continued)

Insulin pump users;

Not currently managed by study physicians;

Pregnant;

Active substance, alcohol, or drug abuser (sober <1 year);

Psychotic or schizophrenic under active care;

Severe hearing or visual impairment; or

No Internet or e-mail access.

\begin{abstract}
Interventions Number of centres: 26 primary care physicians enrolled and randomised
Country: USA

Setting: General practice physicians (internal medicine, family medicine) were recruited from four areas in Maryland, including urban, suburban and rural practices. Physicians in academic settings were not included
\end{abstract}

Outcomes The primary outcome of the study was change in glycated haemoglobin (\%) comparing UC and maximal treatment (CPDS) at baseline versus 12 months.

\title{
Secondary outcomes were:
}

The Patient Health Questionnaire-9 scores at baseline and at follow-up interviews to assess depressive symptoms.

The 9-item version of the Self-Completion Patient Outcome Instrument to assess patient-reported symptoms associated with diabetes

The 17-item Diabetes Distress Scale.

Clinical measurement related to diabetes complications (blood pressure, lipid levels)

Hypoglycemic events, hospitalisations, and emergency room visits

\begin{tabular}{ll}
\hline Study details & Not terminated before regular end \\
\hline Publication details & Language: English \\
& Funding: This study was funded through a contract between the University of Maryland Baltimore and \\
& WellDoc in addition to contributions by WellDoc, CareFirst Blue Cross/Blue Shield of Maryland, LifeS- \\
can, and Sprint. Additional funding was provided by the Maryland Industrial Partnerships program \\
through the University of Maryland, an initiative of the A. James Clark School of Engineering's Maryland \\
Technology Enterprise Institute.
\end{tabular}

Publication status: Peer reviewed journal

Stated aim of study

To test whether adding mobile application coaching and patient/provider web portals to community primary care compared with standard diabetes management would reduce glycated haemoglobin levels in patients with type 2 diabetes.

Notes Diabetes Distress scale scores seem too low to be on the full scale - are these from a sub scale? Contacted author, no response.

\section{Risk of bias}

\begin{tabular}{lll}
\hline Bias & Authors' judgement & Support for judgement \\
\hline $\begin{array}{l}\text { Random sequence genera- } \\
\text { tion (selection bias) }\end{array}$ & Unclear risk & $\begin{array}{l}\text { "We randomised at the physician practice level in order to prevent potential } \\
\text { contamination of the study intervention, i.e., all participating physicians at } \\
\text { a practice site were randomised to the same study group. When a physician } \\
\text { practice is contacted, agreement of individual physicians within the practice is } \\
\text { sought, and they are added to the study physician group" }\end{array}$ \\
\hline
\end{tabular}


Quinn 2011 (Continued)

Comment: Insufficient evidence to permit judgement.

\begin{tabular}{|c|c|c|}
\hline $\begin{array}{l}\text { Allocation concealment } \\
\text { (selection bias) }\end{array}$ & Unclear risk & Insufficient evidence to permit judgement. \\
\hline $\begin{array}{l}\text { Blinding (performance } \\
\text { bias and detection bias) } \\
\text { All outcomes }\end{array}$ & High risk & Patients and providers were not blinded. \\
\hline $\begin{array}{l}\text { Incomplete outcome data } \\
\text { (attrition bias) } \\
\text { All outcomes }\end{array}$ & High risk & $\begin{array}{l}\text { Sensitivity analysis using weighted estimating equations (WEE) to address any } \\
\text { residual bias from missing data was done. However the dropout rate in the in- } \\
\text { tervention group was high }(15 / 38=39 \%) \text {. Dropout rate in control group was } \\
10 \% \text {. }\end{array}$ \\
\hline $\begin{array}{l}\text { Selective reporting (re- } \\
\text { porting bias) }\end{array}$ & Low risk & Protocol for the trial published prior to study completion. \\
\hline Other bias & Unclear risk & $\begin{array}{l}\text { The exclusion criteria meant that only patients with private insurance and ac- } \\
\text { cess to the Internet/ email took part in the trial. The characteristics of such pa- } \\
\text { tients might have influenced the efficacy of the intervention and its generalis- } \\
\text { ability. }\end{array}$ \\
\hline
\end{tabular}

Smith 2000

\begin{tabular}{ll} 
Methods & Study design: parallel randomised controlled trial \\
\hline Participants & Inclusion criteria: \\
Women who participated in the Women to Women Diabetes Project had to meet the following study in- \\
clusion criteria: have diabetes (type 1 or 2 ), be between the ages of 35 and 60 years, be able to read and \\
write English, and possess the sight and dexterity to use a computer (but not necessarily be computer \\
literate). In addition, participants were required to have a telephone in their homes and live at least 25 \\
miles outside the 6 major cities of Montana. \\
Exclusion criteria: \\
None stated
\end{tabular}

Interventions

\section{Number of centres: $n / a$}

Country: USA

Setting: From home

Over the telephone: change in health status scale, a sources of support scale and self-reported HbA1c
Mail questionnaires for Personal Resource Questionnaire, Quality of Life index, Social Readjustment
Rating Scale and the Psychosocial Adaptation to Illness Scale

Study details Not terminated before regular end

Publication details Language: English

Funding: Financial support for this research was provided by the American Association of Diabetes Educators Foundation and US West.

Publication status: Peer reviewed journal 
Smith 2000 (Continued)

Stated aim of study

The aims were to (1) test the effects of the computer intervention in providing support, information and education on selected outcomes, and (2) evaluate the women's attitudes toward and satisfaction with the intervention and the support provided.

Notes

Further information needed: Method of sequence generation and allocation concealment. Number of participants completing the study. QOL etc scores after adjustment and any statistics on whether differences were significant or not. Unable to contact author.

\section{Risk of bias}

\begin{tabular}{lll}
\hline Bias & Authors' judgement & Support for judgement \\
\hline $\begin{array}{ll}\text { Random sequence genera- } \\
\text { tion (selection bias) }\end{array}$ & Unclear risk & $\begin{array}{l}\text { "The 30 women were randomised into two groups (computer vs non comput- } \\
\text { er) of 15 each" }\end{array}$ \\
& & Comment: Insufficient evidence to permit judgement. \\
\hline
\end{tabular}

\begin{tabular}{l}
$\begin{array}{l}\text { Allocation concealment } \\
\text { (selection bias) }\end{array}$ Unclear risk No details provided. Insufficient evidence to permit judgement. \\
\hline
\end{tabular}

\begin{tabular}{|c|c|c|}
\hline $\begin{array}{l}\text { Blinding (performance } \\
\text { bias and detection bias) } \\
\text { All outcomes }\end{array}$ & High risk & $\begin{array}{l}\text { Blinding of participants was not possible. No details about blinding of asses- } \\
\text { sors. }\end{array}$ \\
\hline $\begin{array}{l}\text { Incomplete outcome data } \\
\text { (attrition bias) } \\
\text { All outcomes }\end{array}$ & Unclear risk & $\begin{array}{l}\text { Insufficient evidence to permit judgement. Unclear reporting of numbers in- } \\
\text { cluded in the trial. }\end{array}$ \\
\hline $\begin{array}{l}\text { Selective reporting (re- } \\
\text { porting bias) }\end{array}$ & Unclear risk & Insufficient evidence to permit judgement. \\
\hline Other bias & Unclear risk & Small sample size. \\
\hline
\end{tabular}

\section{Wise 1986}

\begin{tabular}{ll}
\hline Methods & Study design: parallel randomised controlled trial \\
\hline Participants & Inclusion criteria: \\
& Patients regularly attending the diabetic clinic who were seen over a 2 month period at Charing Cross \\
Hospital in London. Diagnosis of type $1 / 2$ diabetes for at least 2 years.
\end{tabular}

\begin{tabular}{ll}
\hline Interventions & Number of centres: 1 \\
& Country: UK \\
& Setting: Diabetic clinic at Charing Cross Hospital, London \\
\hline Outcomes & Knowledge status measured by knowledge-assessment program and HbAlc \\
\hline Study details & Not terminated before regular end \\
\hline Publication details & Language: English \\
& $\begin{array}{l}\text { Funding: Supported by the British Diabetic Association and the Northe West Thames Regional Re- } \\
\text { search Committee }\end{array}$
\end{tabular}


Wise 1986 (Continued)

Publication status: Peer reviewed journal

Stated aim of study The purpose of our study was to examine separately two programs recently developed in this department to define any effects on knowledge and diabetic control.

Notes Details of allocation concealment and SD of outcome measures if available. Unable to find current contact details for author.

\section{Risk of bias}

\begin{tabular}{lll}
\hline Bias & Authors' judgement & Support for judgement \\
\hline $\begin{array}{l}\text { Random sequence genera- } \\
\text { tion (selection bias) }\end{array}$ & High risk & "Assignment to test groups was randomised by year and month of birth" \\
\hline $\begin{array}{l}\text { Allocation concealment } \\
\text { (selection bias) }\end{array}$ & Unclear risk & $\begin{array}{l}\text { Insufficient evidence to permit judgement: no details of allocation conceal- } \\
\text { ment provided. }\end{array}$ \\
\hline $\begin{array}{l}\text { Blinding (performance } \\
\text { bias and detection bias) } \\
\text { All outcomes }\end{array}$ & High risk & $\begin{array}{l}\text { Control group "unaware of the study" and no details about blinding of asses- } \\
\text { sors - study design makes it likely that assessors were aware of allocation }\end{array}$ \\
\hline $\begin{array}{l}\text { Incomplete outcome data } \\
\text { (attrition bias) } \\
\text { All outcomes }\end{array}$ & Unclear risk & $\begin{array}{l}\text { Insufficient evidence to permit judgement: details of number of patients re- } \\
\text { cruited at the start not reported. }\end{array}$ \\
\hline $\begin{array}{l}\text { Selective reporting (re- } \\
\text { porting bias) }\end{array}$ & Unclear risk & Insufficient evidence to permit judgement. \\
\hline \begin{tabular}{l} 
Other bias \\
\hline
\end{tabular} & Low risk & Nothing detected \\
\hline
\end{tabular}

Yoo 2009

\begin{tabular}{|c|c|}
\hline Methods & Study design: parallel randomised controlled trial \\
\hline \multirow[t]{2}{*}{ Participants } & $\begin{array}{l}\text { Inclusion criteria: between } 30 \text { and } 70 \text { years of age, who met the following criteria: (i) a diagnosis of } \\
\text { both type } 2 \text { diabetes and hypertension at least } 1 \text { year previously by a physician; (ii) HbAlc } 6.5 \%-10.0 \% \text {; } \\
\text { (iii) blood pressure > } 130 / 80 \mathrm{mmHg} \text {; and (iv) BMI } ¥ 23.0 \mathrm{~kg} \mathrm{~m} 2 \text { (overweight according to Asia-Pacific cri- } \\
\text { teria) }\end{array}$ \\
\hline & $\begin{array}{l}\text { Exclusion criteria: i) severe diabetic complications (e.g. diabetic foot or severe diabetic retinopathy); } \\
\text { (ii) liver dysfunction with aspartate aminotransferase or alanine aminotransferase }>2.5 \text { times the ref- } \\
\text { erence level, or renal dysfunction (serum creatinine }>132 \text { micro mol/L); (iii) medical history of conges- } \\
\text { tive heart failure, angina pectoris, MI, or stroke based on a physician’s diagnosis; (iv) pregnancy or lac- } \\
\text { tation; or (v) other medical problems that could affect study results or trial participation or (Vi) exclud- } \\
\text { ed all participants with hsCRP } \ddagger 15.0 \mathrm{mg} \text { to rule out any occult inflammatory or infectious disorders. }\end{array}$ \\
\hline
\end{tabular}

Interventions

\section{Number of centres: 2}

Country: South Korea

Setting: 1. University hospital setting (Korea University)

2. Community healthcare centre (Guro-Gu Public Health Centre

Outcomes

BMI was calculated as weight/height2 $(\mathrm{kg} / \mathrm{m} 2)$. Blood chemistry was analysed at the Korea University Guro Hospital laboratory (Seoul, Korea). The glucose oxidase method was employed to measure plas- 
Yoo 2009 (Continued)

ma glucose. A human insulin-specific radioimmunoassay kit (Linco Research Inc., St Charles, MO, USA) was used to measure insulin levels, with a coefficient of variation (CV) of $2.2 \%$. This kit had a cross reactivity of $<0.2 \%$ with human proinsulin. Insulin resistance was calculated by the homeostasis model assessment. Serum total cholesterol, triglycerides, and high-density lipoprotein cholesterol were determined by enzymatic methods using a chemical analyser (Hitachi 747, Tokyo, Japan). HbA1c was analysed by high-performance liquid chromatography using a Variant II analyser (Bio-Rad Laboratories, Hercules, CA, USA). Plasma adiponectin levels were measured using an adiponectin enzyme immunoassay kit (Phoenix Pharmaceuticals, Belmont, CA, USA), with a CV of 3.2\%. Plasma IL-6 levels were measured using a Quantikine kit (R\&D Systems, Belmont, CA, USA) with a CV of 8.1\%. Plasma high-sensitivity (hs) CRP levels were measured using a hsCRP kit (Immunodiagno, Benshaim, Germany) with a CV of $9.2 \%$.

\begin{tabular}{ll}
\hline Study details & Not terminated before regular end \\
\hline Publication details & Language: English \\
& $\begin{array}{l}\text { Funding: Seoul R \& BD Project. The development of the HSA business model and technology was spon- } \\
\text { sored by the Ministry of Commerce, Industry and Energy }\end{array}$
\end{tabular}

Publication status: Peer reviewed journal

$\begin{array}{ll}\text { Stated aim of study } & \text { Our goal was to examine whether a Ubiquitous Chronic Disease Care (UCDC) system using both the } \\ \text { Internet and cellular phones could facilitate chronic disease self-management and improve multiple } \\ \text { metabolic parameters in overweight patients with both type } 2 \text { diabetes and hypertension better than } \\ \text { conventional health care in out-patient clinics. }\end{array}$

Notes

Further information needed: clarify data for BPs - need clarification re. inconsistencies between tables and text re $\mathrm{HbA1C}$, Full details of randomisation needed. Contacted author, no response.

\section{Risk of bias}

\begin{tabular}{lll}
\hline Bias & Authors' judgement & Support for judgement \\
\hline $\begin{array}{l}\text { Random sequence genera- } \\
\text { tion (selection bias) }\end{array}$ & Unclear risk & $\begin{array}{l}\text { "We recruited patients for this open-label, randomised, controlled, prospec- } \\
\text { tive study from both a university hospital setting" }\end{array}$ \\
& $\begin{array}{l}\text { Comment: No details provided of randomisations procedures. Insufficient evi- } \\
\text { dence to permit judgement. }\end{array}$ \\
\hline
\end{tabular}

\begin{tabular}{|c|c|c|}
\hline $\begin{array}{l}\text { Allocation concealment } \\
\text { (selection bias) }\end{array}$ & Unclear risk & $\begin{array}{l}\text { No details provided about allocation concealment. Insufficient evidence to } \\
\text { permit judgement. }\end{array}$ \\
\hline
\end{tabular}

Blinding (performance $\quad$ High risk
bias and detection bias)
All outcomes

\begin{tabular}{|c|c|c|}
\hline $\begin{array}{l}\text { Incomplete outcome data } \\
\text { (attrition bias) } \\
\text { All outcomes }\end{array}$ & Unclear risk & $\begin{array}{l}\text { "Five patients ( } 8.1 \%) \text { dropped out of the intervention group and seven ( } 10 \%) \\
\text { out of the control group. The characteristics of patients who did and did not } \\
\text { drop out were similar in both the intervention and control groups" }\end{array}$ \\
\hline
\end{tabular}

Comment: No details provided about reasons for patients dropping out. No imputation of data or intention-to-treat analysis reported. Insufficient evidence to permit judgement.

Selective reporting (re- Unclear risk Insufficient evidence to permit judgement.
porting bias)

\begin{tabular}{ll}
\hline Other bias $\quad$ Low risk $\quad$ Nothing detected \\
\hline
\end{tabular}


Zhou 2003

\begin{tabular}{|c|c|}
\hline Methods & Study design: parallel randomised controlled trial \\
\hline \multirow[t]{4}{*}{ Participants } & Inclusion criteria: \\
\hline & $\begin{array}{l}\text { Selection criteria: diagnosed according to WHO diagnostic criteria } 1985 \text {, age over } 35 \text { years, previously } \\
\text { received glucose lowering medication, and the dosage of medication remained constant at least two } \\
\text { weeks prior to the selection. }\end{array}$ \\
\hline & Exclusion criteria: \\
\hline & $\begin{array}{l}\text { Diabetes with other severe or acute complications and those with other endocrine disorders, hyperten- } \\
\text { sion (diagnosed according to WHO/ISH Hypertension guidelines), hypercholesterolaemia (principles for } \\
\text { prevention of dyslipidaemia) and glomerular disease (diagnosed according to Morgenson diagnostic } \\
\text { criteria). }\end{array}$ \\
\hline
\end{tabular}

\section{Number of centres: 1}

Country: China

Setting: Endocrinology Department in Second Affiliated Hospital of Zhejiang University

Outcomes HbAlc, BMI, fasting blood glucose, 2-hour post prandial glucose, lipids, urinary albumin excretion

\begin{tabular}{|c|c|c|}
\hline Study details & \multicolumn{2}{|c|}{ Not terminated before regular end } \\
\hline \multirow[t]{3}{*}{ Publication details } & \multicolumn{2}{|l|}{ Language: Chinese } \\
\hline & \multicolumn{2}{|l|}{ Funding: Not stated } \\
\hline & \multicolumn{2}{|c|}{ Publication status: Peer reviewed journal } \\
\hline Stated aim of study & \multicolumn{2}{|c|}{$\begin{array}{l}\text { We developed 'Diabetes diet advisor V1.0 (PC-DR Vision 1.0)'. It consists of more than } 20 \text { thousand com- } \\
\text { mon food types of Chinese people. The objective of this research is to evaluate the efficacy of this soft- } \\
\text { ware in clinical uses. }\end{array}$} \\
\hline Notes & \multicolumn{2}{|c|}{$\begin{array}{l}\text { Further information required: details of allocation concealment and sequence generation. Unable to } \\
\text { find current contact details for author. }\end{array}$} \\
\hline \multicolumn{3}{|l|}{ Risk of bias } \\
\hline Bias & Authors' judgement & Support for judgement \\
\hline \multirow{2}{*}{$\begin{array}{l}\text { Random sequence genera- } \\
\text { tion (selection bias) }\end{array}$} & \multirow[t]{2}{*}{ Unclear risk } & "150 patients are randomly allocated to two groups" \\
\hline & & Comment: Insufficient evidence to permit judgement. \\
\hline $\begin{array}{l}\text { Allocation concealment } \\
\text { (selection bias) }\end{array}$ & Unclear risk & Insufficient evidence to permit judgement. \\
\hline $\begin{array}{l}\text { Blinding (performance } \\
\text { bias and detection bias) } \\
\text { All outcomes }\end{array}$ & High risk & $\begin{array}{l}\text { Insufficient evidence in article. However study design makes blinding highly } \\
\text { unlikely. }\end{array}$ \\
\hline $\begin{array}{l}\text { Incomplete outcome data } \\
\text { (attrition bias) } \\
\text { All outcomes }\end{array}$ & Low risk & No missing data. \\
\hline
\end{tabular}


Zhou 2003 (Continued)

Selective reporting (re- Unclear risk Insufficient evidence to permit judgement.
porting bias)

Other bias Low risk Nothing detected

ADA: American Diabetes Association

BMI: body mass index

BP:blood pressure

hsCRP: high-sensitivity C-reactive protein

MI: myocardial infarction

PVD: peripheral vascular disease

SD: standard deviation

Characteristics of excluded studies [ordered by study ID]

\begin{tabular}{ll}
\hline Study & Reason for exclusion \\
\hline Adams 2009 & $\begin{array}{l}\text { The intervention was non-interactive and consisted of tailored reports that were mailed to partic- } \\
\text { ipants prior to visits. The only interaction with participants was a telephone-based pre-visit ques- } \\
\text { tionnaire based on ADA guidelines. Did not match our criteria for a self-management intervention. }\end{array}$
\end{tabular}

\begin{tabular}{ll}
\hline Albisser 1996 & Not interactive. Did not match our criteria for a self-management intervention. \\
\hline Avdal 2011 & $\begin{array}{l}\text { Did not match our criteria for a self-management intervention. Fitted more with our criteria for } \\
\text { telemedicine (nurse-led case management) intervention. }\end{array}$
\end{tabular}

\begin{tabular}{ll}
\hline Billiard 1991 & Participants had type 1 diabetes only. \\
\hline Boaz 2009 & $\begin{array}{l}\text { Did not match our criteria for a self-management intervention. Fitted more with our criteria for } \\
\text { telemedicine intervention. }\end{array}$ \\
\hline Bond 2007 & $\begin{array}{l}\text { Did not match our criteria for a self-management intervention. Fitted more with our criteria for } \\
\text { telemedicine intervention. }\end{array}$ \\
\hline Bond 2010 & $\begin{array}{l}\text { Did not match our criteria for a self-management intervention. Intervention was felt to be a nurse- } \\
\text { led telemedicine intervention more than a computer-based self-management intervention. }\end{array}$
\end{tabular}

Bujnowska-Fedak 2011

Did not match our criteria for a self-management intervention. Fitted more with our criteria for telemedicine intervention.

\section{Carter 2011}

Did not match our criteria for a self-management intervention. Fitted more with our criteria for telemedicine intervention.

\begin{tabular}{ll}
\hline Castelnuovo 2010 & This report described a protocol for telemedicine intervention. \\
\hline Cho 2006 & $\begin{array}{l}\text { Did not match our criteria for a self-management intervention. Fitted more with our criteria for } \\
\text { telemedicine intervention. }\end{array}$ \\
\hline Cho 2009 & Comparison between a mobile phone and Internet-based intervention. No control group. \\
\hline Cleveringa 2007 & $\begin{array}{l}\text { The intervention (Diabetes Care Protocol) was targeted at health professionals. Did not match our } \\
\text { criteria for a self-management intervention. }\end{array}$ \\
\hline Derose 2009 & $\begin{array}{l}\text { The intervention was non-interactive and consisted of automated prompts with telephone calls } \\
\text { and letters. }\end{array}$ \\
\hline
\end{tabular}




\begin{tabular}{ll}
\hline Study & Reason for exclusion \\
\hline
\end{tabular}

Earle 2010

Did not match our criteria for a self-management intervention. Fitted more with our criteria for telemedicine intervention.

Edmonds 1998

Was a feasibility study with no suitable outcome measures. Participants were "insulin-requiring diabetics".

\section{Estrada 2010}

Did not match our criteria for a self-management intervention. The intervention was aimed at healthcare professionals.

\begin{tabular}{ll}
\hline Glasgow 1995 & This report describes a feasibility study not suitable for inclusion. \\
\hline Glasgow 2000 & $\begin{array}{l}\text { 2x2 factorial trial where all participants received a brief computer intervention. This study looked } \\
\text { at the incremental effects of adding telephone follow-up support and community resources. }\end{array}$
\end{tabular}

\begin{tabular}{ll}
\hline Glasgow 2002 & All participants received a computer-based intervention. \\
\hline Glasgow 2005a & Brief report of the findings of the Diabetes Priority Program. \\
\hline Goldberg 2006 & $\begin{array}{l}\text { Did not match our criteria for a self-management intervention. Fitted more with our criteria for a } \\
\text { (nurse-led) telemedicine intervention. }\end{array}$ \\
\hline
\end{tabular}

Graziano 2009

Did not match our criteria for a self-management intervention. The intervention was not interactive and did not provide tailored information.

\begin{tabular}{ll}
\hline Handley 2008 & $\begin{array}{l}\text { The intervention was a non-interactive telephone intervention with nurse care management. Did } \\
\text { not match our criteria for a self-management intervention. }\end{array}$ \\
\hline Harno 2006 & $\begin{array}{l}\text { Did not match our criteria for a self-management intervention. Fitted more with our criteria for an } \\
\text { Internet-based telemedicine intervention. }\end{array}$ \\
\hline Holbrook 2009 & $\begin{array}{l}\text { Did not match our criteria for a self-management intervention. Shared electronic decision-support } \\
\text { system. The intervention was a colour-coded diabetes tracker providing sequential monitoring val- } \\
\text { ues for } 13 \text { diabetes risk factors and the primary outcome measure was a process composite score. }\end{array}$
\end{tabular}

Izquierdo 2010

Did not match our criteria for a self-management intervention. Fitted with our criteria for an Internet-based telemedicine intervention.

\begin{tabular}{ll}
\hline Jones 2006 & Non-randomised controlled trial. \\
\hline Kalten 2000 & $\begin{array}{l}\text { The report described the intervention but provided no results. The intervention required motiva- } \\
\text { tional interviewing to be provided by healthcare professionals, it did not match our criteria for a } \\
\text { self-management intervention. }\end{array}$ \\
\hline
\end{tabular}

Keuthage 2008

\section{Kim 2005}

Commentary on another article (Christian 2008).

Did not match our criteria for a self-management intervention. Fitted more with our criteria for a (mobile phone-based) telemedicine intervention.

\begin{tabular}{ll}
\hline Kim 2006 & $\begin{array}{l}\text { Targeted at healthcare professionals, did not match our criteria for a self-management interven- } \\
\text { tion. }\end{array}$ \\
\hline Kim 2007 & $\begin{array}{l}\text { Did not match our criteria for a self-management intervention. Fitted more with our criteria for a } \\
\text { (mobile phone-based) telemedicine intervention. }\end{array}$ \\
\hline Kim 2007a & $\begin{array}{l}\text { Did not match our criteria for a self-management intervention. Fitted more with our criteria for a } \\
\text { (mobile phone-based) telemedicine intervention }\end{array}$ \\
\hline
\end{tabular}




\section{\begin{tabular}{ll}
\hline Study & Reason for exclusion \\
\hline Kim 2008 & $\begin{array}{l}\text { Did not match our criteria for a self-management intervention. Fitted more with our criteria for a } \\
\text { (mobile phone-based) telemedicine intervention. }\end{array}$
\end{tabular}}

\begin{tabular}{ll}
\hline Kim 2010 & $\begin{array}{l}\text { All patients were started on glargine. The intervention looked at the effect of SMS messages on } \\
\text { titration of insulin. }\end{array}$
\end{tabular}

\begin{tabular}{ll}
\hline King 2006 & $\begin{array}{l}\text { The primary outcome measures included community health activities model program for seniors } \\
\text { questionnaire, diet and psychosocial assessments. HbAlc or quality of life were not included as } \\
\text { outcomes. }\end{array}$ \\
\hline Kwon 2004 & $\begin{array}{l}\text { Did not match our criteria for a self-management intervention. Fitted more with our criteria for a } \\
\text { (mobile phone-based) telemedicine intervention. }\end{array}$
\end{tabular}

\begin{tabular}{ll}
\hline Laffel 2007 & Over $70 \%$ patients with type 1 diabetes. \\
\hline Lee 2007 & $\begin{array}{l}\text { Did not match our criteria for a self-management intervention. The intervention was not interactive } \\
\text { and it was managed by a health professional. }\end{array}$
\end{tabular}

\begin{tabular}{ll}
\hline Liebreich 2009 & $\begin{array}{l}\text { The primary outcome measures included measured physical activity, social cognitive variables. } \\
\text { HbAlc or quality of life were not included as outcomes. }\end{array}$ \\
\hline MacLean 2004 & $\begin{array}{l}\text { Did not match our criteria for a self-management intervention. The intervention was decision sup- } \\
\text { port software and it was aimed at health professionals. }\end{array}$ \\
\hline McMahon 2005 & $\begin{array}{l}\text { Did not match our criteria for a self-management intervention. Fitted more with our criteria for a } \\
\text { (nurse-led) telemedicine intervention. }\end{array}$ \\
\hline
\end{tabular}

\begin{tabular}{|c|c|}
\hline Mollon 2008 & $\begin{array}{l}\text { Did not match our criteria for a self-management intervention. The intervention was an automated } \\
\text { telephone reminder. This report was also just a feasibility study with no clinical outcome measures. }\end{array}$ \\
\hline Morrish 1989 & Participants had type 1 diabetes. \\
\hline Noel 2004 & $\begin{array}{l}\text { Did not match our criteria for a self-management intervention. Fitted more with our criteria for a } \\
\text { telemedicine intervention. }\end{array}$ \\
\hline Oh 2003 & Purely telephone-based intervention, not computer-based. \\
\hline Palmas 2010 & $\begin{array}{l}\text { Did not match our criteria for a self-management intervention. Fitted more with our criteria for a } \\
\text { telemedicine intervention. }\end{array}$ \\
\hline Persson 2000 & Not a randomised controlled trial. \\
\hline Peters 1991 & Participants had type 1 diabetes. \\
\hline Piette 2000 & $\begin{array}{l}\text { Did not match our criteria for a self-management intervention. Non-interactive automated calls } \\
\text { and telephone follow-up from a nurse. }\end{array}$ \\
\hline Piette 2001 & $\begin{array}{l}\text { Did not match our criteria for a self-management intervention. Non-interactive automated calls } \\
\text { and telephone follow-up from a nurse. }\end{array}$ \\
\hline Quinn 2009 & $\begin{array}{l}\text { Did not match our criteria for a self-management intervention. The intervention was a diabetes } \\
\text { communication system, using mobile phones and patient/physician portals to allow patient-spe- } \\
\text { cific treatment and communication. }\end{array}$ \\
\hline Ralston 2009 & $\begin{array}{l}\text { Did not match our criteria for a self-management intervention. Fitted more with our criteria for a } \\
\text { (care-manager led) telemedicine intervention. }\end{array}$ \\
\hline
\end{tabular}




\begin{tabular}{|c|c|}
\hline Study & Reason for exclusion \\
\hline Robertson 2007 & Not a randomised controlled trial. \\
\hline Rodríguez-Idígoras 2009 & $\begin{array}{l}\text { Did not match our criteria for a self-management intervention. Fitted more with our criteria for a } \\
\text { (call-centre protocol managed) telemedicine intervention. }\end{array}$ \\
\hline Ross 2006 & The only outcomes measured were characteristics of and usage by patients. \\
\hline Ryff-de 1992 & Participants had type 1 diabetes. \\
\hline Sarkar 2008 & $\begin{array}{l}\text { Did not match our criteria for a self-management intervention. A non-interactive telephone inter- } \\
\text { vention. }\end{array}$ \\
\hline Schillinger 2009 & $\begin{array}{l}\text { Automated telephone messages or nurse telephone intervention. Did not match our criteria for a } \\
\text { self-management intervention. }\end{array}$ \\
\hline Schrezenmeier 1988 & Participants had type 1 diabetes. \\
\hline Shea 2006 & $\begin{array}{l}\text { Did not match our criteria for a self-management intervention. Fitted more with our criteria for a } \\
\text { telemedicine intervention. }\end{array}$ \\
\hline Shea 2007 & $\begin{array}{l}\text { Did not match our criteria for a self-management intervention. Fitted more with our criteria for a } \\
\text { telemedicine intervention. }\end{array}$ \\
\hline Shea 2009 & $\begin{array}{l}\text { Did not match our criteria for a self-management intervention. Fitted more with our criteria for a } \\
\text { telemedicine intervention. }\end{array}$ \\
\hline Sherifali 2011 & $\begin{array}{l}\text { Not an interactive intervention. Intervention was a mail out of a tailored letter. Did not fit our crite- } \\
\text { ria for a self-management intervention. }\end{array}$ \\
\hline Shultz 1991 & $\begin{array}{l}\text { Did not match our criteria for a self-management intervention. Modem data transfer to clinicians } \\
\text { only. }\end{array}$ \\
\hline Smith 2004 & $\begin{array}{l}\text { Did not match our criteria for a self-management intervention. Fitted more with our criteria for a } \\
\text { (nurse case management) telemedicine intervention. }\end{array}$ \\
\hline Song 2009 & Not a randomised controlled trial. \\
\hline Stone 2010 & $\begin{array}{l}\text { Did not match our criteria for a self-management intervention. Fitted more with our criteria for a } \\
\text { telemedicine intervention. }\end{array}$ \\
\hline Tildesley 2011 & $\begin{array}{l}\text { Did not match our criteria for a self-management intervention. Fitted more with our criteria for a } \\
\text { telemedicine intervention. }\end{array}$ \\
\hline Tjam 2006 & $\begin{array}{l}\text { Did not match our criteria for a self-management intervention. Fitted more with our criteria for a } \\
\text { (Internet-based) telemedicine intervention. }\end{array}$ \\
\hline Trief 2007 & $\begin{array}{l}\text { Did not match our criteria for a self-management intervention. Fitted more with our criteria for a } \\
\text { telemedicine intervention. }\end{array}$ \\
\hline Tsang 2001 & Participants had type 1 diabetes. \\
\hline Turnin 1992 & $70 \%$ of participants had type 1 diabetes. \\
\hline van Bastelaar 2011 & $\begin{array}{l}\text { Did not match our criteria for a self-management intervention. Fitted more with our criteria for a } \\
\text { telemedicine intervention as not fully automated and significant interaction with health profes- } \\
\text { sionals. }\end{array}$ \\
\hline
\end{tabular}




\begin{tabular}{ll}
\hline Study & Reason for exclusion \\
\hline van Bastelaar 2011a & $\begin{array}{l}\text { Did not match our criteria for a self-management intervention. Fitted more with our criteria for a } \\
\text { telemedicine intervention as not fully automated and significant interaction with health profes- } \\
\text { sionals }\end{array}$ \\
\hline Vespasiani 2008 & Participants had type 1 diabetes. \\
\hline Wakefield 2011 & $\begin{array}{l}\text { Did not match our criteria for a self-management intervention. Fitted more with our criteria for a } \\
\text { telemedicine intervention. }\end{array}$ \\
\hline Yeh 2006 & $\begin{array}{l}\text { Did not match our criteria for a self-management intervention. Aimed at health professionals, not } \\
\text { an interactive patient focused intervention. }\end{array}$ \\
\hline Yoo 2008 & $\begin{array}{l}\text { The study compared } 2 \text { types of blood glucose monitoring. } \\
\text { Yoon } 2008\end{array}$ \\
\hline
\end{tabular}

ADA: American Diabetes Association

Characteristics of studies awaiting assessment [ordered by study ID]

Faridi 2008

Methods
Study design: parallel randomised control trial
Participants
Inclusion criteria:
Patients meeting the following inclusion criteria were included in the study:
(i) age $\geq 18$ years; (ii) type 2 diabetes diagnosed by a health professional at least 1 year prior and
confirmed by other clinical laboratory data (Fasting Plasma Glucose $>126 \mathrm{mg} / \mathrm{dL}$ and/or 2 -hour $75-$
g oral glucose tolerance test OGTT $>200 \mathrm{mg} / \mathrm{dL}$ );
(iii) controlled by either diet or oral medications for at least 3 months;
(iv) BMI > 25 ;
(v) no exogenous insulin use;
(vi) a glycosylated haemoglobin (HbAlc) $<8 \%$ reflecting fair to good glycaemic control; and
(vi) serum creatinine $<1.5 \mathrm{mg} / \mathrm{dL}$.

\section{Exclusion criteria:}

None stated.

\section{Number of centres: 2}

The study was conducted in collaboration with a primary care network in Connecticut (Community Health Centers - CHC). Two of the seven $\mathrm{CHC}$ clinics with similar demographic characteristics in the network elected to participate.

Country: US.

Setting: community and at home.

\section{Outcomes}

1) Feasibility was assessed as utilisation of the system by community health centre patients and consistent use of the system by patients over the 3-month intervention period. Utilisation was 
Faridi 2008 (Continued)

measured in the intervention group by mining the data collected by the NICHE server to obtain information about the utilisation of separate components. Additionally, post-intervention focus groups were held with intervention patients to illuminate patients' barriers when utilising the technology.

2) Utility in enhancing diabetes management: assessed as pre- and post-intervention change in clinical measures and surveys relevant to diabetic self-care in the intervention and control group. Clinical measures included $\mathrm{HbA1c}$ levels, trend analysis of glucometer readings between groups, and BMI. Additionally, physical activity levels were measured both by pedometers and self-report using the Yale Physical Activity Scale (YPAS). Patients' self-efficacy was assessed as via the Diabetes Self-efficacy Scale (DSES). Patrticipants' diabetes management was recorded using the Diabetes Self-care Activities (SDSCA).

\section{Study details}

Publication details

Not terminated before regular end.

Language: English

Funding: Small Business Technology Transfer Resarch Program, grant number IR21DKK072321-01

Publication status: Peer reviewed journal

"The primary aim of the study is to examine the feasibility of utilizing this technology to assist with diabetes self care in a clinic population as well as its impact on clinical outcomes"
Stated aim of study

Notes

Lorig 2006

Methods Study design: parallel randomised control trial

\section{Participants}

\section{Inclusion criteria:}

Participants met all of the following criteria:

1) at least 18 years of age;

2) a physician's diagnosis of heart disease, chronic lung disease or type 2 diabetes;

3) in addition to one of these diagnoses, partlcipant could have other chronic conditions but could not have been in active treatment of cancer for 1 year;

4) not participated in the small-group Chronic Disease Self-Management Program;

5) access to a computer with Internet and email capabilities;

6) agreed to 1-2 hours per week of log on time spread over at least 3 sessions/wk for 6 weeks;

7) are able to complete the online questionnaire.

\section{Exclusion criteria:}

None separately stated.

\section{Number of centres: 1}

Country: US

Setting: Participants used the Internet from home

$$
\text { (VNS) were used to measure pain/physical discomfort, shortness of breath, and fatigue. }
$$


Lorig 2006 (Continued)

The Illness Intrusiveness Scale measured the impact of disease on role activities such as work, recreation, and social activities.

The Health Distress Scale was adapted from the Medical Outcome Study.

Self-Rated Global Health was used as it is predictive of future health status.

The 20-item Health Assessment Instrument measures disability.

Four health-related behaviours were measured: stretching and strengthening exercise, aerobic exercise, use of cognitive symptom management techniques, and use of techniques to improve communication with healthcare providers.

\begin{tabular}{ll}
\hline Study details & Not terminated before regular end. \\
\hline Publication details & Language: English \\
& Funding: Not stated \\
& Publication status: Peer reviewed journal \\
\hline Stated aim of study & To determine the efficacy of the Internet-based CDSMP \\
\hline Notes & $\begin{array}{l}\text { Need diabetes specific data - contacted author. Diabetes data not available separately and mixed } \\
\text { diabetic population. Would require re-analysis of data. }\end{array}$ \\
\hline
\end{tabular}

Noh 2010

\begin{tabular}{ll}
\hline Methods & Study design: parallel randomised control trial \\
\hline Participants & Inclusion criteria: \\
& Patients $18-80$ years old with type 2 diabetes either drug naive or who had received prior drug \\
therapy and had a glycated haemoglobin (A1C) level between $7 \%$ and $10 \%$ with stable glycaemic \\
control were recruited. Stable glycaemic control was defined by no recent addition of hypogly- \\
caemic medications or change in insulin dosing by $>10 \%$ in the previous 3 months. Persons partici- \\
pating in this study had Internet assess in their homes, their own cellular phone, and the ability to \\
access the Internet and mobile website.
\end{tabular}

\section{Exclusion criteria:}

Participants with severe medical illnesses including liver cirrhosis, end stage renal disease, and cancer were excluded.

Interventions

\section{Number of centres: 5 hospitals}

Country: South Korea

Setting: Mobile and Internet-based intervention, patients recruited from hospital

Outcomes Primary end points for the study were the changes in glycaemic control (A1C, fasting plasma glucose [FPG], and 2-h postprandial plasma [PP2] glucose).

\begin{tabular}{ll}
\hline Study details & Not terminated before regular end \\
\hline Publication details & Language: English \\
& Funding: This research was supported by a grant from the Korean Diabetes Association. \\
& Publication status: Peer reviewed journal \\
\hline
\end{tabular}


Noh 2010 (Continued)

Stated aim of study

Notes

The aim of this study was to evaluate the effect of this computer- and cellular phone accessible web-based system on glycaemic control.

BMI: body mass index

OGTT: oral glucose tolerance test

\section{DATA AND ANALYSES}

\section{Comparison 1. HbA1c}

\begin{tabular}{|c|c|c|c|c|}
\hline Outcome or subgroup title & No. of studies & $\begin{array}{l}\text { No. of partici- } \\
\text { pants }\end{array}$ & Statistical method & Effect size \\
\hline $1 \mathrm{HbA} 1 \mathrm{c}$ & 11 & 2637 & $\begin{array}{l}\text { Mean Difference (IV, Random, } \\
95 \% \mathrm{CI} \text { ) }\end{array}$ & $-0.21[-0.37,-0.05]$ \\
\hline 1.1 Change in mean & 3 & 943 & $\begin{array}{l}\text { Mean Difference (IV, Random, } \\
95 \% \mathrm{CI} \text { ) }\end{array}$ & $0.06[-0.27,0.39]$ \\
\hline 1.2 Mean difference & 8 & 1694 & $\begin{array}{l}\text { Mean Difference (IV, Random, } \\
95 \% \mathrm{CI})\end{array}$ & $-0.32[-0.52,-0.12]$ \\
\hline $\begin{array}{l}2 \text { Sensitivity analysis - removing } \\
\text { Christian } 2008\end{array}$ & 10 & 2364 & $\begin{array}{l}\text { Mean Difference (IV, Random, } \\
95 \% \mathrm{CI})\end{array}$ & $-0.25[-0.40,-0.10]$ \\
\hline $\begin{array}{l}3 \text { Sensitivity analysis - removing } \\
\text { Leu } 2005\end{array}$ & 10 & 2600 & $\begin{array}{l}\text { Mean Difference (IV, Random, } \\
95 \% \mathrm{CI})\end{array}$ & $-0.23[-0.39,-0.07]$ \\
\hline $\begin{array}{l}4 \text { Sensitivity analysis - removing } \\
\text { cluster randomised trials }\end{array}$ & 9 & 2005 & $\begin{array}{l}\text { Mean Difference (IV, Random, } \\
95 \% \mathrm{CI})\end{array}$ & $-0.22[-0.39,-0.05]$ \\
\hline $\begin{array}{l}5 \text { Sensitivity analysis - remove } \\
\text { Glasgow } 2003\end{array}$ & 10 & 2477 & $\begin{array}{l}\text { Mean Difference (IV, Random, } \\
95 \% \mathrm{CI})\end{array}$ & $-0.21[-0.38,-0.04]$ \\
\hline $\begin{array}{l}6 \text { Subgroup analysis - outcomes at } \\
\text { less than } 6 \text { months }\end{array}$ & 5 & 842 & $\begin{array}{l}\text { Mean Difference (IV, Random, } \\
95 \% \mathrm{CI})\end{array}$ & $-0.32[-0.58,-0.07]$ \\
\hline $\begin{array}{l}7 \text { Subgroup analysis - outcomes at } \\
\text { later than } 6 \text { months }\end{array}$ & 6 & 1795 & $\begin{array}{l}\text { Mean Difference (IV, Random, } \\
95 \% \mathrm{CI})\end{array}$ & $-0.14[-0.33,0.05]$ \\
\hline $\begin{array}{l}8 \text { Subgroup analysis - mobile } \\
\text { phone based interventions }\end{array}$ & 3 & 280 & $\begin{array}{l}\text { Mean Difference (IV, Random, } \\
95 \% \mathrm{CI})\end{array}$ & $-0.50[-0.74,-0.26]$ \\
\hline $\begin{array}{l}9 \text { Subgroup analysis - interven- } \\
\text { tions based at home }\end{array}$ & 4 & 1188 & $\begin{array}{l}\text { Mean Difference (IV, Random, } \\
95 \% \mathrm{CI})\end{array}$ & $-0.25[-0.47,-0.04]$ \\
\hline
\end{tabular}


Analysis 1.1. Comparison 1 HbA1c, Outcome 1 HbA1c.

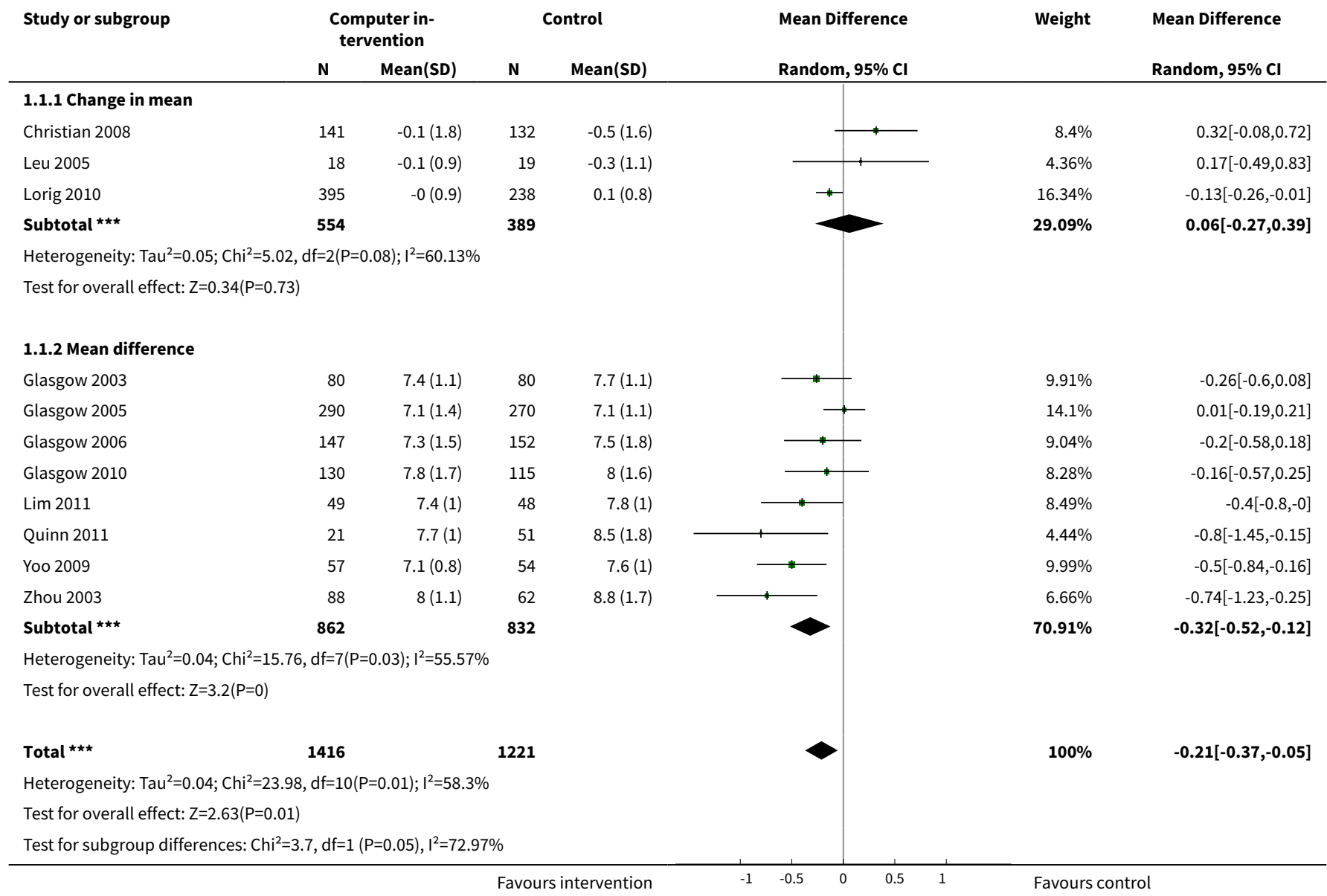

Analysis 1.2. Comparison 1 HbA1c, Outcome 2 Sensitivity analysis - removing Christian 2008.

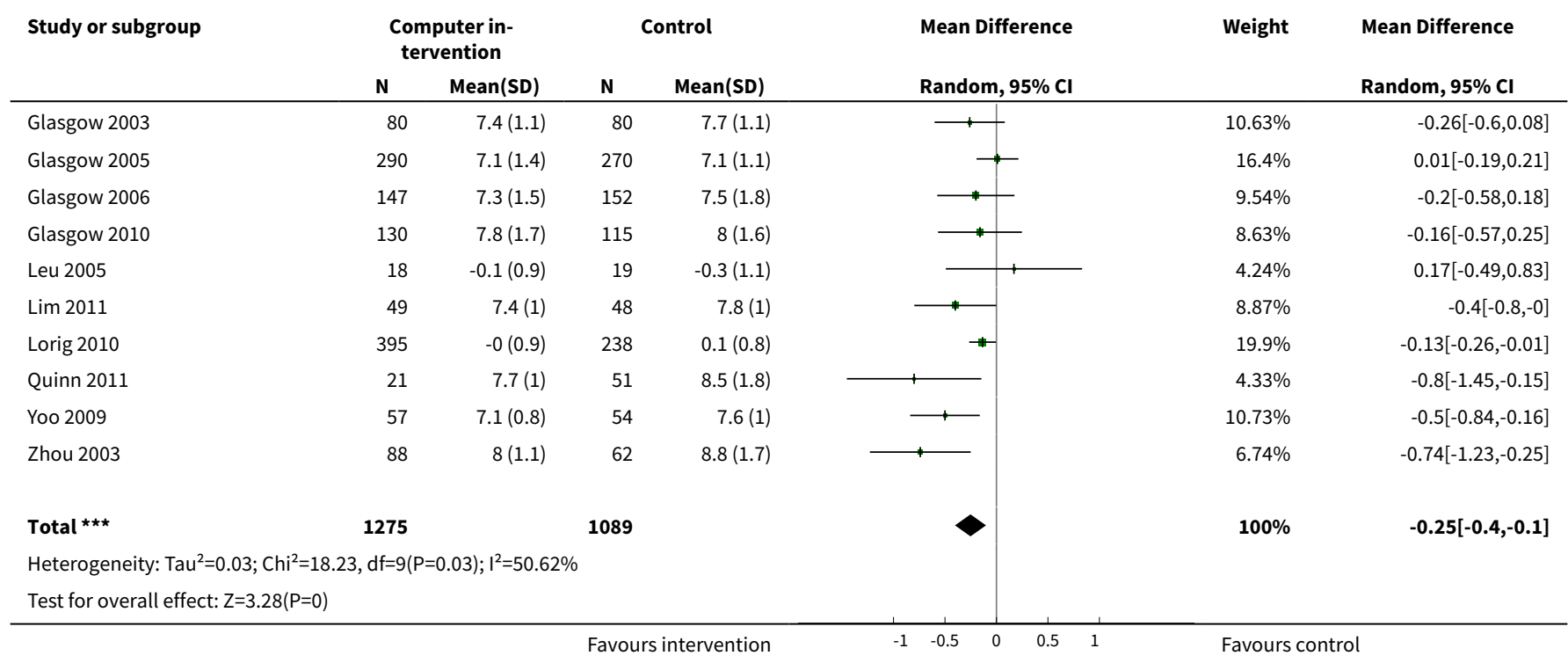


Analysis 1.3. Comparison 1 HbA1c, Outcome 3 Sensitivity analysis - removing Leu 2005.

\begin{tabular}{|c|c|c|c|c|c|c|c|}
\hline \multirow[t]{2}{*}{ Study or subgroup } & \multicolumn{2}{|c|}{$\begin{array}{l}\text { Computer in- } \\
\text { tervention }\end{array}$} & \multicolumn{2}{|c|}{ Control } & \multirow{2}{*}{$\begin{array}{l}\text { Mean Difference } \\
\text { Random, } 95 \% \mathrm{CI}\end{array}$} & \multirow[t]{2}{*}{ Weight } & \multirow{2}{*}{$\begin{array}{l}\text { Mean Difference } \\
\text { Random, } 95 \% \mathrm{Cl}\end{array}$} \\
\hline & $\mathbf{N}$ & Mean(SD) & $\mathbf{N}$ & Mean(SD) & & & \\
\hline Christian 2008 & 141 & $-0.1(1.8)$ & 132 & $-0.5(1.6)$ & $\longrightarrow$ & $8.81 \%$ & $0.32[-0.08,0.72]$ \\
\hline Glasgow 2003 & 80 & $7.4(1.1)$ & 80 & $7.7(1.1)$ & 1 & $10.37 \%$ & $-0.26[-0.6,0.08]$ \\
\hline Glasgow 2005 & 290 & $7.1(1.4)$ & 270 & $7.1(1.1)$ & + & $14.66 \%$ & $0.01[-0.19,0.21]$ \\
\hline Glasgow 2006 & 147 & $7.3(1.5)$ & 152 & $7.5(1.8)$ & $\longrightarrow$ & $9.47 \%$ & $-0.2[-0.58,0.18]$ \\
\hline Glasgow 2010 & 130 & $7.8(1.7)$ & 115 & $8(1.6)$ & ? & $8.69 \%$ & $-0.16[-0.57,0.25]$ \\
\hline Lim 2011 & 49 & $7.4(1)$ & 48 & $7.8(1)$ & +— & $8.91 \%$ & $-0.4[-0.8,-0]$ \\
\hline Lorig 2010 & 395 & $-0(0.9)$ & 238 & $0.1(0.8)$ & $\rightarrow$ & $16.93 \%$ & $-0.13[-0.26,-0.01]$ \\
\hline Quinn 2011 & 21 & $7.7(1)$ & 51 & $8.5(1.8)$ & - & $4.69 \%$ & $-0.8[-1.45,-0.15]$ \\
\hline Yoo 2009 & 57 & $7.1(0.8)$ & 54 & $7.6(1)$ & 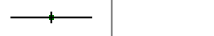 & $10.45 \%$ & $-0.5[-0.84,-0.16]$ \\
\hline Zhou 2003 & 88 & $8(1.1)$ & 62 & $8.8(1.7)$ & + & $7.01 \%$ & $-0.74[-1.23,-0.25]$ \\
\hline Total $\star \star \star ~$ & 1398 & & 1202 & & 0 & $100 \%$ & $-0.23[-0.39,-0.07]$ \\
\hline \multicolumn{8}{|c|}{ Heterogeneity: Tau $^{2}=0.04 ; \mathrm{Chi}^{2}=23, \mathrm{df}=9(\mathrm{P}=0.01) ; 1^{2}=60.87 \%$} \\
\hline \multicolumn{8}{|c|}{ Test for overall effect: $Z=2.77(P=0.01)$} \\
\hline
\end{tabular}

Analysis 1.4. Comparison 1 HbA1c, Outcome 4 Sensitivity analysis - removing cluster randomised trials.

\begin{tabular}{|c|c|c|c|c|c|c|c|}
\hline \multirow{3}{*}{$\begin{array}{l}\text { Study or subgroup } \\
\text { Christian } 2008\end{array}$} & \multicolumn{2}{|c|}{$\begin{array}{l}\text { Computer in- } \\
\text { tervention }\end{array}$} & \multicolumn{2}{|c|}{ Control } & \multirow{2}{*}{$\begin{array}{l}\text { Mean Difference } \\
\text { Random, } 95 \% \mathrm{CI}\end{array}$} & & \multirow{2}{*}{$\begin{array}{l}\text { Mean Difference } \\
\text { Random, } 95 \% \mathrm{Cl}\end{array}$} \\
\hline & $\mathbf{N}$ & Mean(SD) & $\mathbf{N}$ & Mean(SD) & & & \\
\hline & 141 & $-0.1(1.8)$ & 132 & $-0.5(1.6)$ & 4 & $10.24 \%$ & $0.32[-0.08,0.72]$ \\
\hline Glasgow 2003 & 80 & $7.4(1.1)$ & 80 & $7.7(1.1)$ & - & $12.16 \%$ & $-0.26[-0.6,0.08]$ \\
\hline Glasgow 2006 & 147 & $7.3(1.5)$ & 152 & $7.5(1.8)$ & 1 & $11.04 \%$ & $-0.2[-0.58,0.18]$ \\
\hline Glasgow 2010 & 130 & $7.8(1.7)$ & 115 & $8(1.6)$ & - & $10.1 \%$ & $-0.16[-0.57,0.25]$ \\
\hline Leu 2005 & 18 & $-0.1(0.9)$ & 19 & $-0.3(1.1)$ & & $5.23 \%$ & $0.17[-0.49,0.83]$ \\
\hline Lim 2011 & 49 & $7.4(1)$ & 48 & $7.8(1)$ & - & $10.36 \%$ & $-0.4[-0.8,-0]$ \\
\hline Lorig 2010 & 395 & $-0(0.9)$ & 238 & $0.1(0.8)$ & 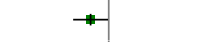 & $20.55 \%$ & $-0.13[-0.26,-0.01]$ \\
\hline Yoo 2009 & 57 & $7.1(0.8)$ & 54 & $7.6(1)$ & & $12.25 \%$ & $-0.5[-0.84,-0.16]$ \\
\hline Zhou 2003 & 88 & $8(1.1)$ & 62 & $8.8(1.7)$ & $*$ & $8.07 \%$ & $-0.74[-1.23,-0.25]$ \\
\hline 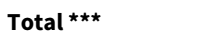 & 1105 & & 900 & & 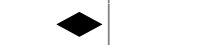 & $100 \%$ & $-0.22[-0.39,-0.05]$ \\
\hline \multicolumn{8}{|c|}{ Heterogeneity: $\operatorname{Tau}^{2}=0.03 ; \mathrm{Chi}^{2}=17.31, \mathrm{df}=8(\mathrm{P}=0.03) ; \mathrm{I}^{2}=53.79 \%$} \\
\hline \multicolumn{8}{|c|}{ Test for overall effect: $Z=2.49(P=0.01)$} \\
\hline
\end{tabular}

Analysis 1.5. Comparison 1 HbA1c, Outcome 5 Sensitivity analysis - remove Glasgow 2003.

\begin{tabular}{|c|c|c|c|c|c|c|c|}
\hline \multirow[t]{2}{*}{ Study or subgroup } & \multicolumn{2}{|c|}{$\begin{array}{c}\text { Computer in- } \\
\text { tervention }\end{array}$} & \multicolumn{2}{|c|}{ Control } & \multirow{2}{*}{$\begin{array}{l}\text { Mean Difference } \\
\text { Random, } 95 \% \mathrm{Cl}\end{array}$} & \multirow[t]{2}{*}{ Weight } & \multirow{2}{*}{$\begin{array}{l}\text { Mean Difference } \\
\text { Random, } 95 \% \mathrm{Cl}\end{array}$} \\
\hline & $\mathbf{N}$ & $\operatorname{Mean}(S D)$ & $\mathbf{N}$ & Mean(SD) & & & \\
\hline Christian 2008 & 141 & $-0.1(1.8)$ & 132 & $-0.5(1.6)$ & $\longrightarrow$ & $9.47 \%$ & $0.32[-0.08,0.72]$ \\
\hline Glasgow 2005 & 290 & $7.1(1.4)$ & 270 & $7.1(1.1)$ & $\rightarrow$ & $15.18 \%$ & $0.01[-0.19,0.21]$ \\
\hline
\end{tabular}




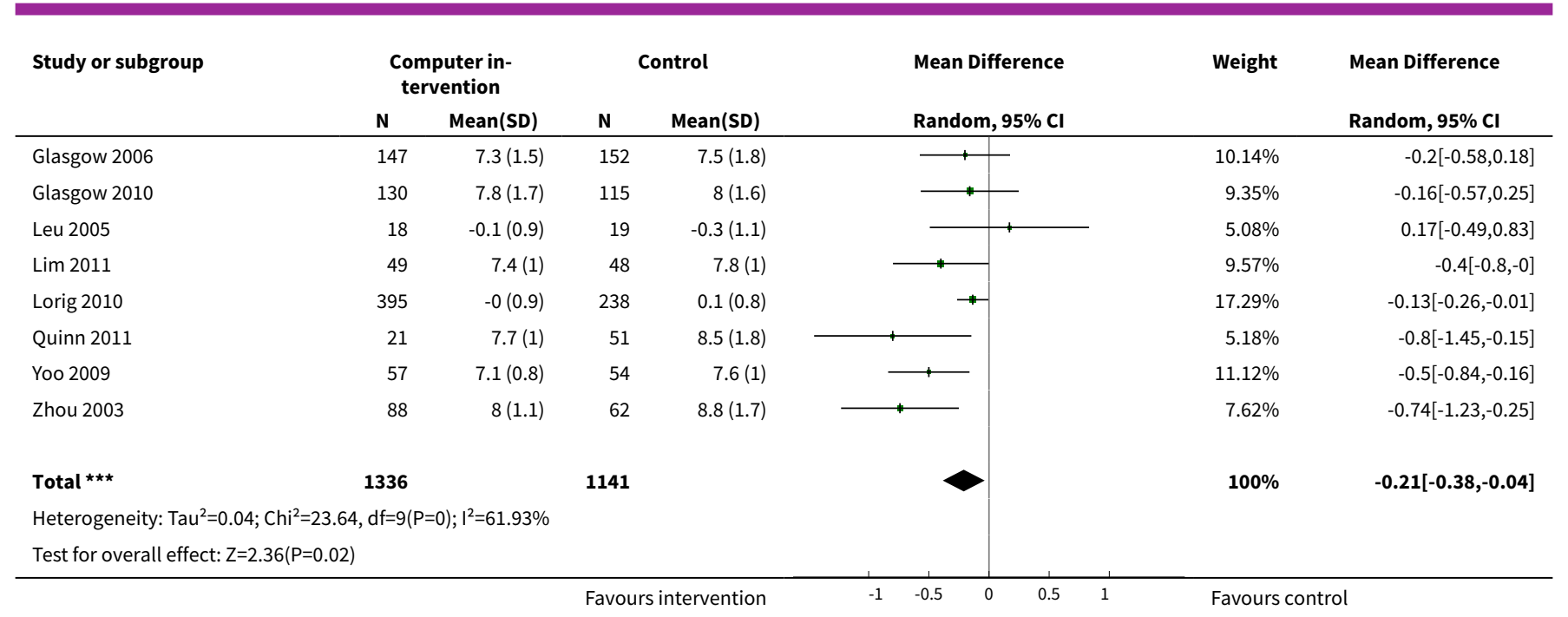

Analysis 1.6. Comparison $1 \mathrm{HbA1c}$, Outcome 6 Subgroup analysis - outcomes at less than 6 months.

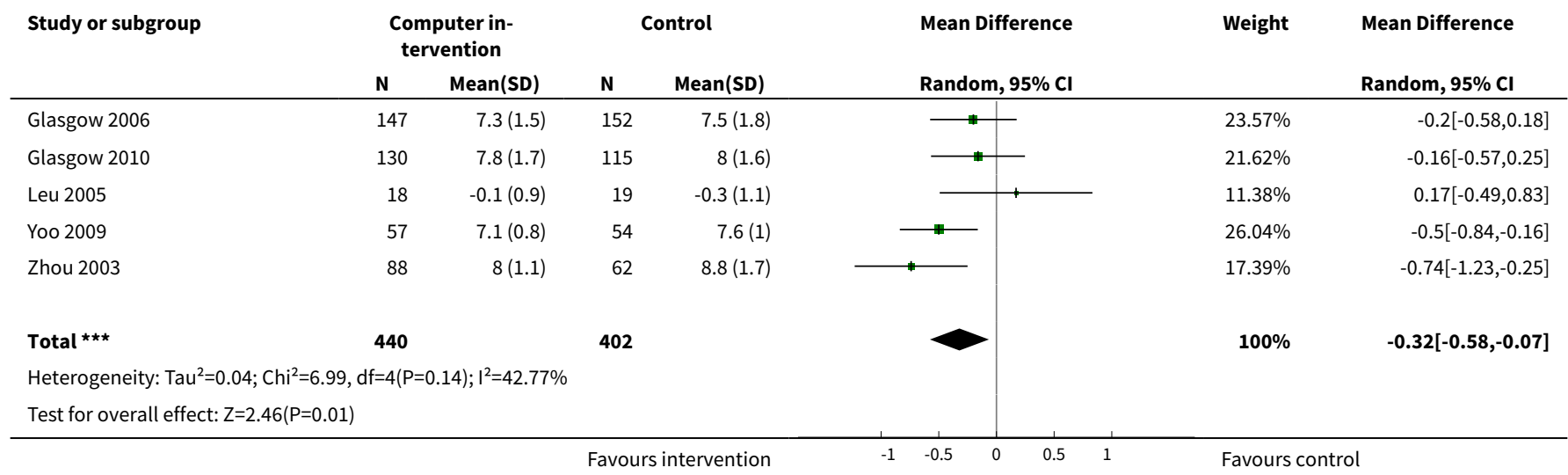

Analysis 1.7. Comparison $1 \mathrm{HbA1c}$, Outcome 7 Subgroup analysis - outcomes at later than 6 months.

\begin{tabular}{|c|c|c|c|c|c|c|c|}
\hline \multirow[t]{2}{*}{ Study or subgroup } & \multicolumn{2}{|c|}{$\begin{array}{l}\text { Computer in- } \\
\text { tervention }\end{array}$} & \multicolumn{2}{|c|}{ Control } & \multirow{2}{*}{$\begin{array}{l}\text { Mean Difference } \\
\text { Random, 95\% Cl }\end{array}$} & \multirow[t]{2}{*}{ Weight } & \multirow{2}{*}{$\begin{array}{l}\text { Mean Difference } \\
\text { Random, } 95 \% \mathrm{CI}\end{array}$} \\
\hline & $\mathbf{N}$ & Mean(SD) & $\mathbf{N}$ & Mean(SD) & & & \\
\hline Christian 2008 & 141 & $-0.1(1.8)$ & 132 & $-0.5(1.6)$ & + & $13.24 \%$ & $0.32[-0.08,0.72]$ \\
\hline Glasgow 2003 & 80 & $7.4(1.1)$ & 80 & $7.7(1.1)$ & + & $15.81 \%$ & $-0.26[-0.6,0.08]$ \\
\hline Glasgow 2005 & 290 & $7.1(1.4)$ & 270 & $7.1(1.1)$ & $\rightarrow$ & $23.27 \%$ & $0.01[-0.19,0.21]$ \\
\hline Lim 2011 & 49 & $7.4(1)$ & 48 & $7.8(1)$ & $\rightarrow$ & $13.4 \%$ & $-0.4[-0.8,-0]$ \\
\hline Quinn 2011 & 21 & $7.7(1)$ & 51 & $8.5(1.8)$ & $\rightarrow$ & $6.79 \%$ & $-0.8[-1.45,-0.15]$ \\
\hline 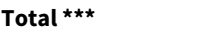 & 976 & & 819 & & & $100 \%$ & $-0.14[-0.33,0.05]$ \\
\hline \multicolumn{8}{|c|}{ Heterogeneity: $\mathrm{Tau}^{2}=0.03 ; \mathrm{Chi}^{2}=12.91, \mathrm{df}=5(\mathrm{P}=0.02) ; \mathrm{I}^{2}=61.26 \%$} \\
\hline \multicolumn{8}{|c|}{ Test for overall effect: $Z=1.44(P=0.15)$} \\
\hline
\end{tabular}


Analysis 1.8. Comparison 1 HbA1c, Outcome 8 Subgroup analysis - mobile phone based interventions.

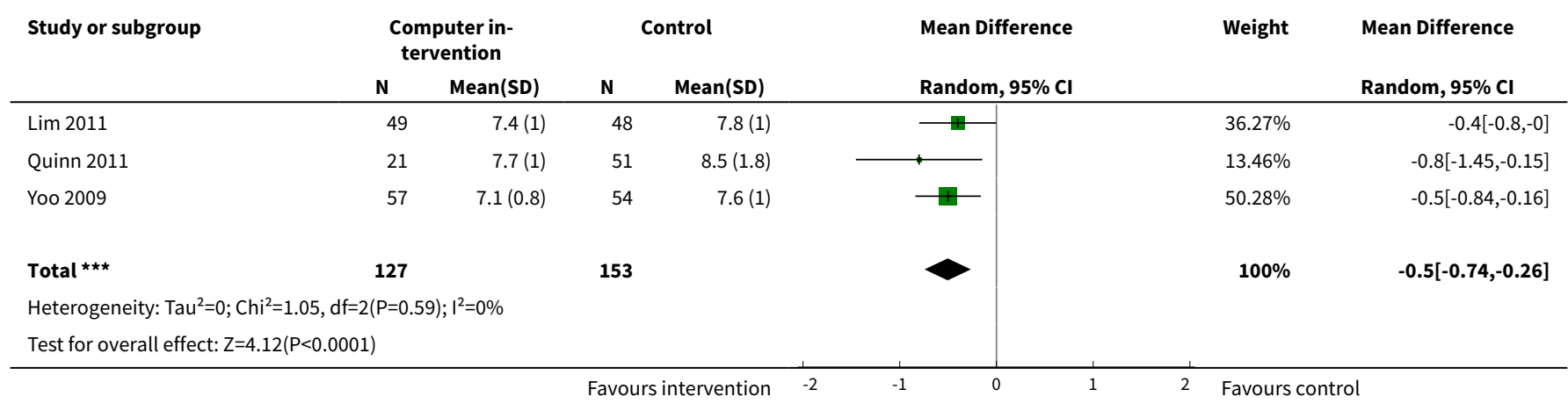

Analysis 1.9. Comparison $1 \mathrm{HbA1C}$, Outcome 9 Subgroup analysis - interventions based at home.

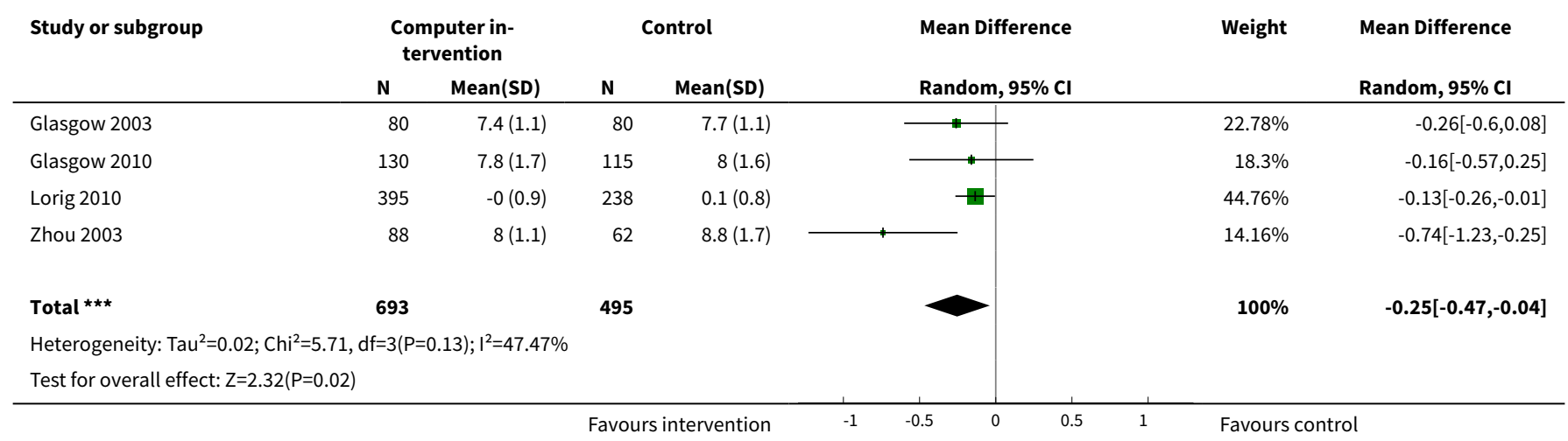

\section{Comparison 2. Dietary change}

\begin{tabular}{|c|c|c|c|c|}
\hline Outcome or subgroup title & No. of studies & $\begin{array}{l}\text { No. of partici- } \\
\text { pants }\end{array}$ & Statistical method & Effect size \\
\hline $\begin{array}{l}1 \text { Fruit and vegetable } \\
\text { screener score }\end{array}$ & 1 & 299 & Mean Difference (IV, Random, 95\% CI) & $0.60[-0.35,1.55]$ \\
\hline 2 Estimated daily fat intake & 2 & 544 & Mean Difference (IV, Random, 95\% CI) & $-3.44[-7.93,1.05]$ \\
\hline 3 Change in calorific intake & 1 & & Mean Difference (IV, Random, 95\% CI) & Totals not selected \\
\hline 4 Pooled effect on diet & 3 & 819 & $\begin{array}{l}\text { Std. Mean Difference (IV, Random, } \\
95 \% \mathrm{CI} \text { ) }\end{array}$ & $-0.29[-0.43,-0.15]$ \\
\hline $\begin{array}{l}4.1 \text { Estimated daily fat in- } \\
\text { take }\end{array}$ & 2 & 546 & $\begin{array}{l}\text { Std. Mean Difference (IV, Random, } \\
95 \% \mathrm{CI} \text { ) }\end{array}$ & $-0.32[-0.49,-0.16]$ \\
\hline $\begin{array}{l}4.2 \text { Change in weekly calorie } \\
\text { intake }\end{array}$ & 1 & 273 & $\begin{array}{l}\text { Std. Mean Difference (IV, Random, } \\
95 \% \mathrm{Cl} \text { ) }\end{array}$ & $-0.23[-0.46,0.01]$ \\
\hline
\end{tabular}


Analysis 2.1. Comparison 2 Dietary change, Outcome 1 Fruit and vegetable screener score.

\begin{tabular}{|c|c|c|c|c|c|c|c|}
\hline \multirow[t]{2}{*}{ Study or subgroup } & \multicolumn{2}{|c|}{$\begin{array}{l}\text { Computer in- } \\
\text { tervention }\end{array}$} & \multicolumn{2}{|c|}{ Control } & \multirow{2}{*}{$\begin{array}{l}\text { Mean Difference } \\
\text { Random, } 95 \% \mathrm{Cl}\end{array}$} & \multirow[t]{2}{*}{ Weight } & \multirow{2}{*}{$\begin{array}{l}\text { Mean Difference } \\
\text { Random, } 95 \% \mathrm{Cl}\end{array}$} \\
\hline & $\mathbf{N}$ & $\operatorname{Mean}(\mathrm{SD})$ & $\mathbf{N}$ & $\operatorname{Mean}(S D)$ & & & \\
\hline Glasgow 2006 & 147 & $5.7(4.8)$ & 152 & $5.1(3.4)$ & & $100 \%$ & $0.6[-0.35,1.55]$ \\
\hline 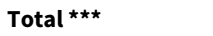 & 147 & & 152 & & 1 & $100 \%$ & $0.6[-0.35,1.55]$ \\
\hline \multicolumn{8}{|c|}{ Heterogeneity: Not applicable } \\
\hline Test for overall effec & & & & & & & \\
\hline
\end{tabular}

Analysis 2.2. Comparison 2 Dietary change, Outcome 2 Estimated daily fat intake.

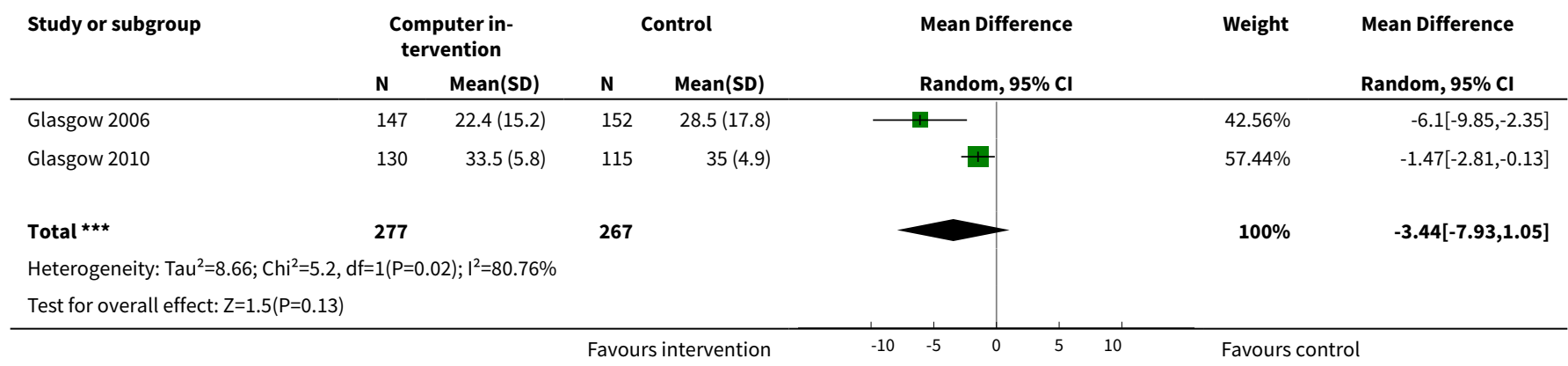

Analysis 2.3. Comparison 2 Dietary change, Outcome 3 Change in calorific intake.

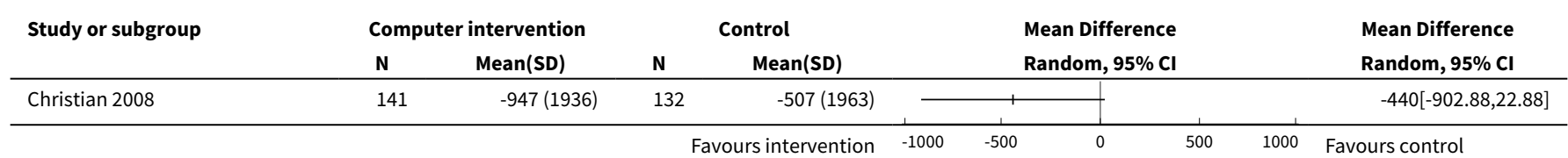

Analysis 2.4. Comparison 2 Dietary change, Outcome 4 Pooled effect on diet.

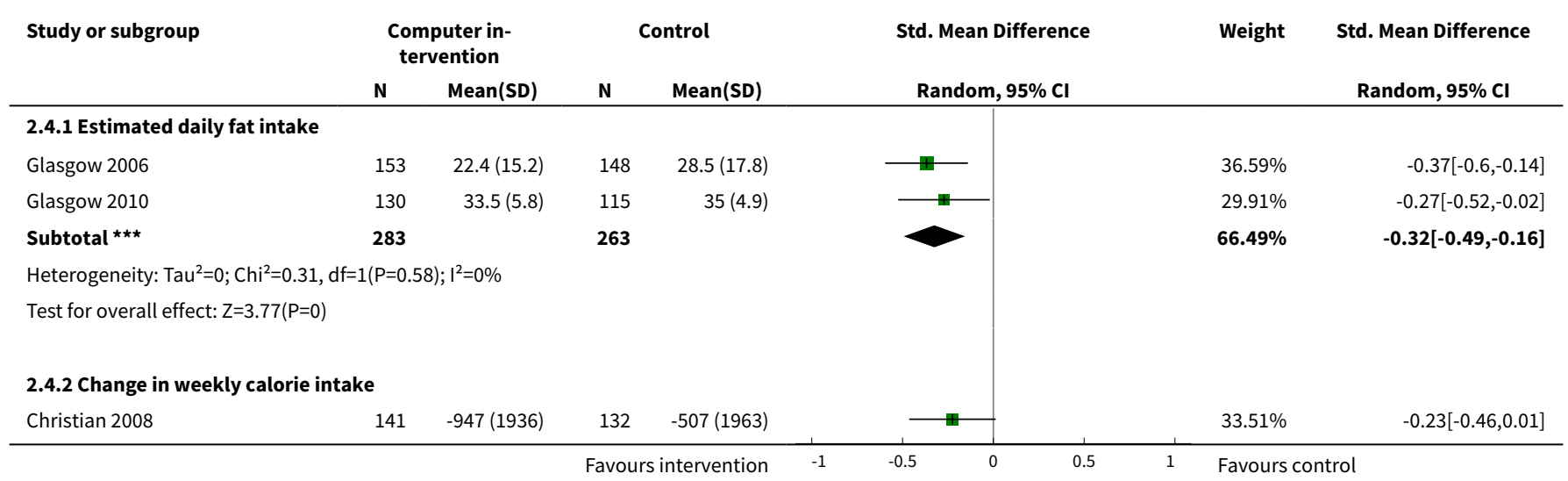




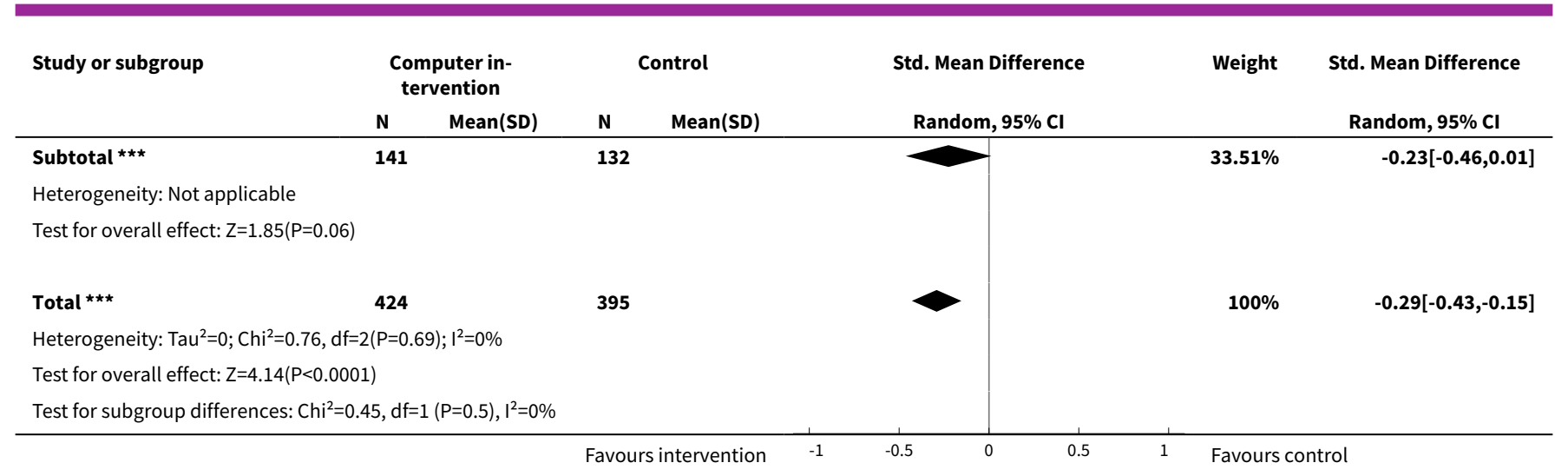

\section{Comparison 3. Impact on weight or BMI}

\begin{tabular}{llllll}
\hline $\begin{array}{l}\text { Outcome or sub- } \\
\text { group title }\end{array}$ & No. of studies & $\begin{array}{l}\text { No. of partici- } \\
\text { pants }\end{array}$ & Statistical method & Effect size \\
\hline $\begin{array}{l}1 \text { Pooled effect on } \\
\text { weight or BMI }\end{array}$ & 5 & & Std. Mean Difference (IV, Random, 95\% Cl) & Subtotals only \\
\hline 1.1 Weight & 3 & 507 & Std. Mean Difference (IV, Random, 95\% Cl) & $-0.05[-0.22,0.13]$ \\
\hline 1.2 Change in weight & 1 & 273 & Std. Mean Difference (IV, Random, 95\% Cl) & $-0.14[-0.38,0.09]$ \\
\hline 1.3 BMI & 1 & 245 & Std. Mean Difference (IV, Random, 95\% Cl) & $-0.06[-0.31,0.19]$ \\
\hline
\end{tabular}

Analysis 3.1. Comparison 3 Impact on weight or BMI, Outcome 1 Pooled effect on weight or BMI.

\begin{tabular}{|c|c|c|c|c|c|c|c|}
\hline \multirow[t]{2}{*}{ Study or subgroup } & \multicolumn{2}{|c|}{$\begin{array}{c}\text { Computer in- } \\
\text { tervention }\end{array}$} & \multicolumn{2}{|c|}{ Control } & \multirow{2}{*}{$\begin{array}{l}\text { Std. Mean Difference } \\
\text { Random, } 95 \% \mathrm{Cl} \\
\end{array}$} & \multirow[t]{2}{*}{ Weight } & \multirow{2}{*}{$\begin{array}{l}\text { Std. Mean Difference } \\
\text { Random, 95\% Cl } \\
\end{array}$} \\
\hline & $\mathbf{N}$ & Mean(SD) & $\mathbf{N}$ & Mean(SD) & & & \\
\hline \multicolumn{8}{|l|}{ 3.1.1 Weight } \\
\hline Glasgow 2006 & 147 & $93.6(23.6)$ & 152 & $94(24.5)$ & & $59 \%$ & $-0.02[-0.24,0.21]$ \\
\hline Lim 2011 & 49 & $63.5(8.5)$ & 48 & $64.2(9.4)$ & & $19.13 \%$ & $-0.08[-0.48,0.32]$ \\
\hline Yoo 2009 & 57 & $65.3(12.7)$ & 54 & $66.4(10.4)$ & & $21.87 \%$ & $-0.09[-0.47,0.28]$ \\
\hline Subtotal $\star \star \star ~$ & 253 & & 254 & & & $100 \%$ & $-0.05[-0.22,0.13]$ \\
\hline \multicolumn{8}{|c|}{ Heterogeneity: $\operatorname{Tau}^{2}=0 ; \mathrm{Chi}^{2}=0.15, \mathrm{df}=2(\mathrm{P}=0.93) ; \mathrm{I}^{2}=0 \%$} \\
\hline \multicolumn{8}{|c|}{ Test for overall effect: $Z=0.51(P=0.61)$} \\
\hline \multicolumn{8}{|c|}{ 3.1.2 Change in weight } \\
\hline Christian 2008 & 141 & $-0.1(5)$ & 132 & $0.6(4.8)$ & & $100 \%$ & $-0.14[-0.38,0.09]$ \\
\hline Subtotal $\star \star \star$ & 141 & & 132 & & & $100 \%$ & $-0.14[-0.38,0.09]$ \\
\hline \multicolumn{8}{|c|}{ Heterogeneity: Not applicable } \\
\hline \multicolumn{8}{|c|}{ Test for overall effect: $Z=1.19(P=0.23)$} \\
\hline \multicolumn{8}{|l|}{ 3.1.3 BMI } \\
\hline Glasgow 2010 & 130 & $34.4(6.3)$ & 115 & $34.8(6.6)$ & & $100 \%$ & $-0.06[-0.31,0.19]$ \\
\hline Subtotal $\star \star \star$ & 130 & & 115 & & & $100 \%$ & $-0.06[-0.31,0.19]$ \\
\hline \multicolumn{8}{|c|}{ Heterogeneity: Not applicable } \\
\hline & & & Favou & ervention & -0.5 & Favours & \\
\hline
\end{tabular}




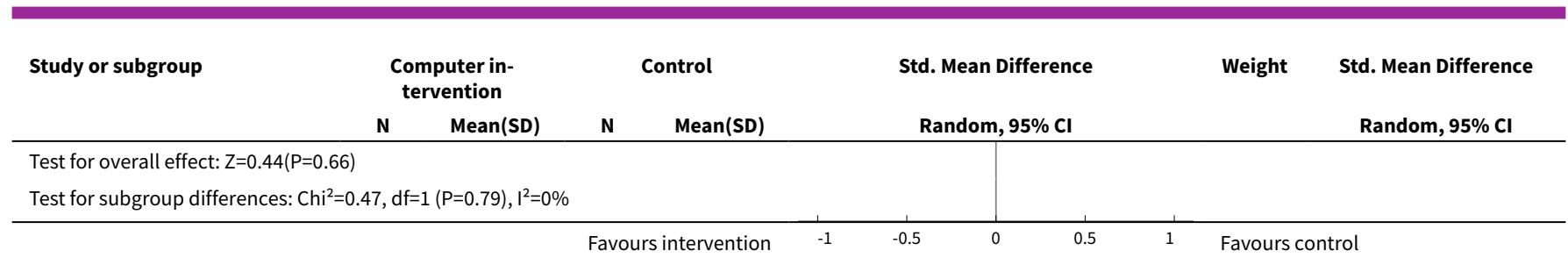

\section{Comparison 4. Lipids}

\begin{tabular}{|c|c|c|c|c|}
\hline $\begin{array}{l}\text { Outcome or subgroup ti- } \\
\text { tle }\end{array}$ & No. of studies & $\begin{array}{l}\text { No. of partici- } \\
\text { pants }\end{array}$ & Statistical method & Effect size \\
\hline 1 Total cholesterol & 4 & 567 & Mean Difference (IV, Random, 95\% CI) & $-0.19[-0.41,0.02]$ \\
\hline $\begin{array}{l}2 \text { Change in total choles- } \\
\text { terol }\end{array}$ & 1 & & Mean Difference (IV, Random, 95\% CI) & Totals not selected \\
\hline $\begin{array}{l}3 \text { High density lipoprotein } \\
\text { (HDL) }\end{array}$ & 2 & 446 & Mean Difference (IV, Random, 95\% CI) & $-0.01[-0.08,0.05]$ \\
\hline 4 Change in $\mathrm{HDL}$ & 1 & & Mean Difference (IV, Random, 95\% CI) & Totals not selected \\
\hline $\begin{array}{l}5 \text { Low density lipoprotein } \\
\text { (LDL) }\end{array}$ & 1 & & Mean Difference (IV, Random, 95\% CI) & Totals not selected \\
\hline 6 Change in LDL & 1 & & Mean Difference (IV, Random, 95\% CI) & Totals not selected \\
\hline 7 TC:HDL ratio & 3 & 1466 & Mean Difference (IV, Random, 95\% CI) & $0.05[-0.07,0.16]$ \\
\hline 8 Change in triglycerides & 1 & & Mean Difference (IV, Random, 95\% CI) & Totals not selected \\
\hline $\begin{array}{l}9 \text { Pooled effect on choles- } \\
\text { terol }\end{array}$ & 7 & 1625 & $\begin{array}{l}\text { Std. Mean Difference (IV, Random, } \\
95 \% \mathrm{CI} \text { ) }\end{array}$ & $-0.11[-0.28,0.05]$ \\
\hline 9.1 Total cholesterol & 4 & 567 & $\begin{array}{l}\text { Std. Mean Difference (IV, Random, } \\
95 \% \mathrm{CI} \text { ) }\end{array}$ & $-0.22[-0.48,0.04]$ \\
\hline $\begin{array}{l}9.2 \text { Change in total choles- } \\
\text { terol }\end{array}$ & 1 & 273 & $\begin{array}{l}\text { Std. Mean Difference (IV, Random, } \\
95 \% \mathrm{CI} \text { ) }\end{array}$ & $-0.27[-0.50,-0.03]$ \\
\hline $\begin{array}{l}\text { 9.3 Total cholesterol:HDL } \\
\text { cholesterol ratio }\end{array}$ & 2 & 785 & $\begin{array}{l}\text { Std. Mean Difference (IV, Random, } \\
95 \% \mathrm{Cl} \text { ) }\end{array}$ & $0.06[-0.08,0.20]$ \\
\hline
\end{tabular}

Analysis 4.1. Comparison 4 Lipids, Outcome 1 Total cholesterol.

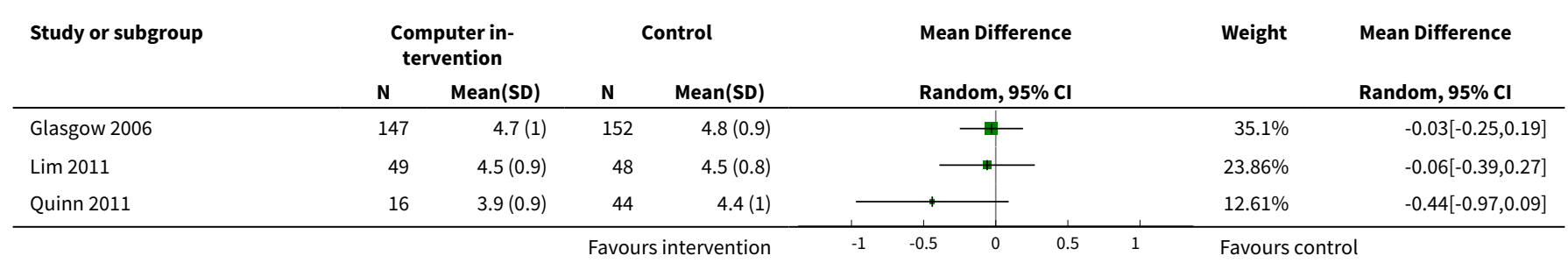




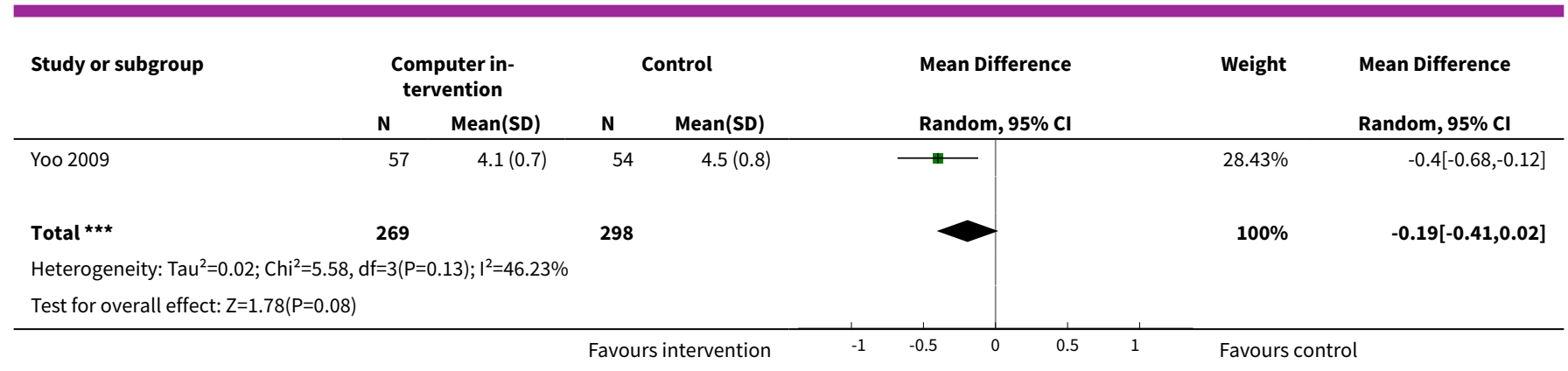

Analysis 4.2. Comparison 4 Lipids, Outcome 2 Change in total cholesterol.

\begin{tabular}{|c|c|c|c|c|c|c|c|}
\hline \multirow[t]{2}{*}{ Study or subgroup } & \multicolumn{2}{|c|}{ Computer intervention } & \multicolumn{2}{|c|}{ Control } & \multirow{2}{*}{\multicolumn{2}{|c|}{$\begin{array}{l}\text { Mean Difference } \\
\text { Random, } 95 \% \mathrm{Cl}\end{array}$}} & \multirow{3}{*}{$\begin{array}{l}\begin{array}{l}\text { Mean Difference } \\
\text { Random, 95\% Cl }\end{array} \\
-0.31[-0.57,-0.05]\end{array}$} \\
\hline & $\mathbf{N}$ & Mean(SD) & $\mathbf{N}$ & Mean(SD) & & & \\
\hline Christian 2008 & 155 & $-0.4(1.2)$ & 155 & $-0.1(1.2)$ & + & & \\
\hline
\end{tabular}

Analysis 4.3. Comparison 4 Lipids, Outcome 3 High density lipoprotein (HDL).

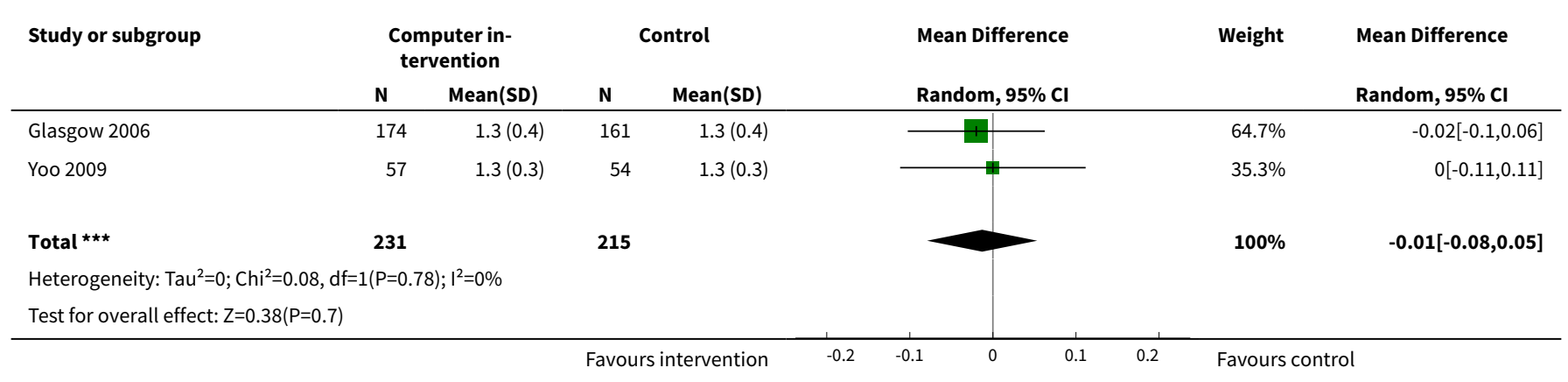

\section{Analysis 4.4. Comparison 4 Lipids, Outcome 4 Change in HDL.}

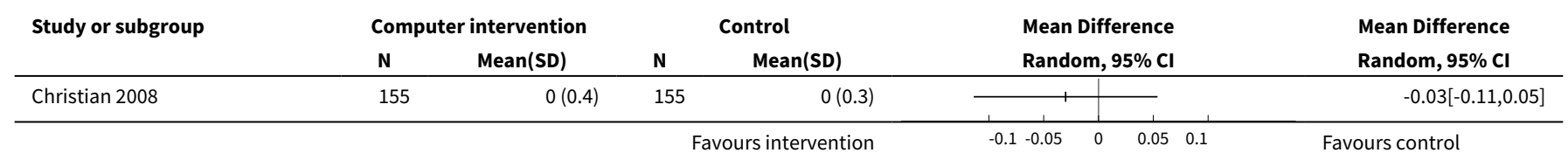

Analysis 4.5. Comparison 4 Lipids, Outcome 5 Low density lipoprotein (LDL).

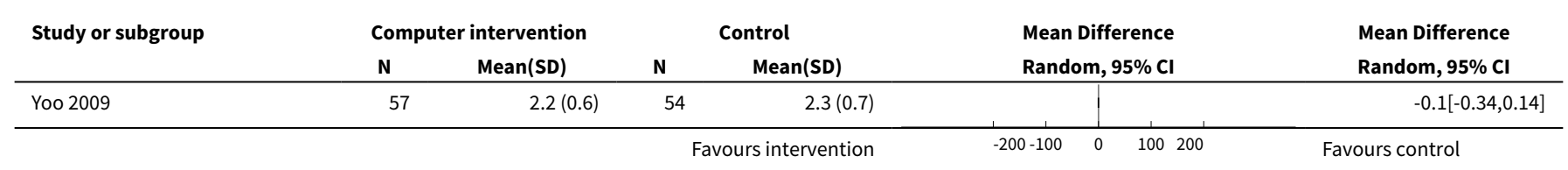




\section{Analysis 4.6. Comparison 4 Lipids, Outcome 6 Change in LDL.}

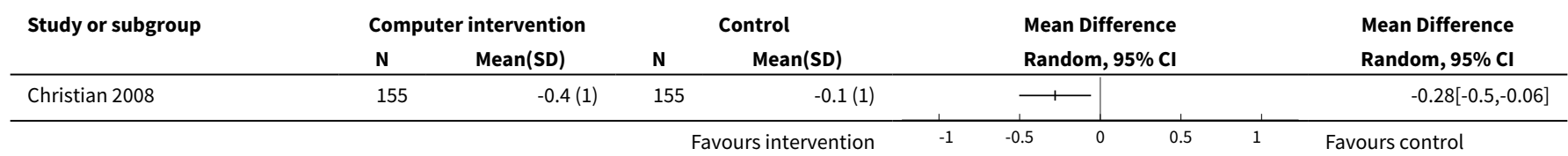

\section{Analysis 4.7. Comparison 4 Lipids, Outcome 7 TC:HDL ratio.}

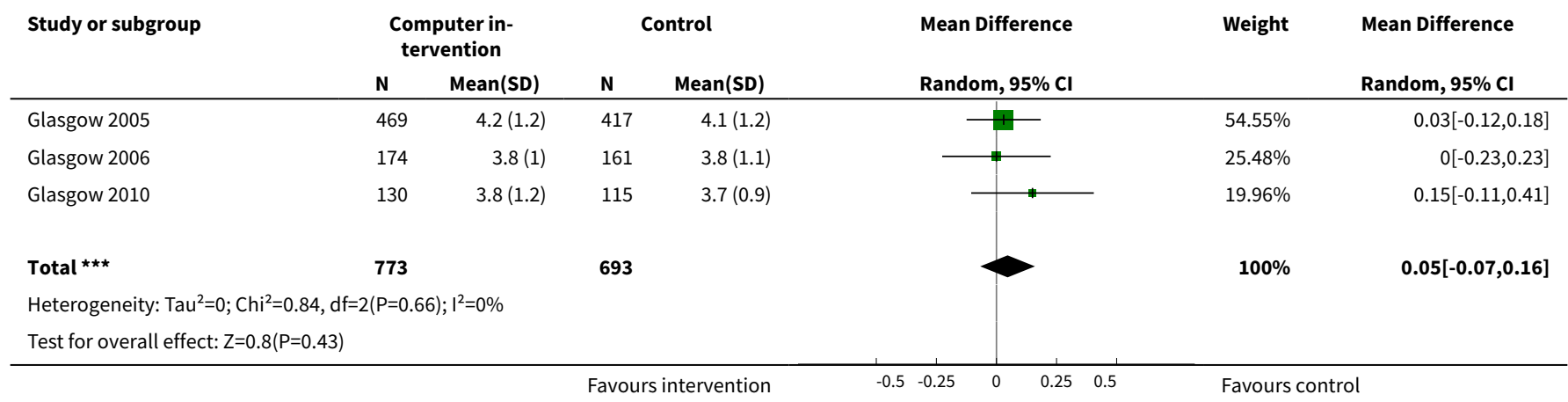

Analysis 4.8. Comparison 4 Lipids, Outcome 8 Change in triglycerides.

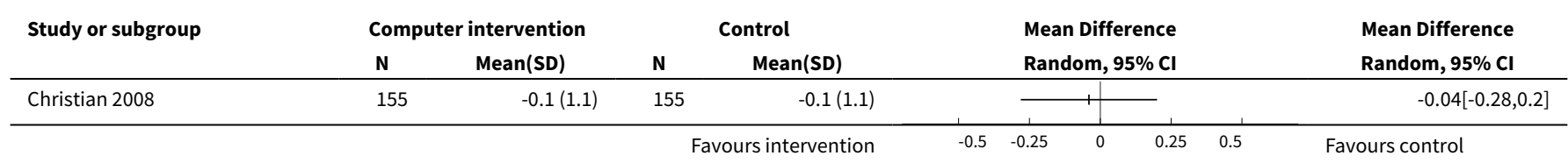

Analysis 4.9. Comparison 4 Lipids, Outcome 9 Pooled effect on cholesterol.

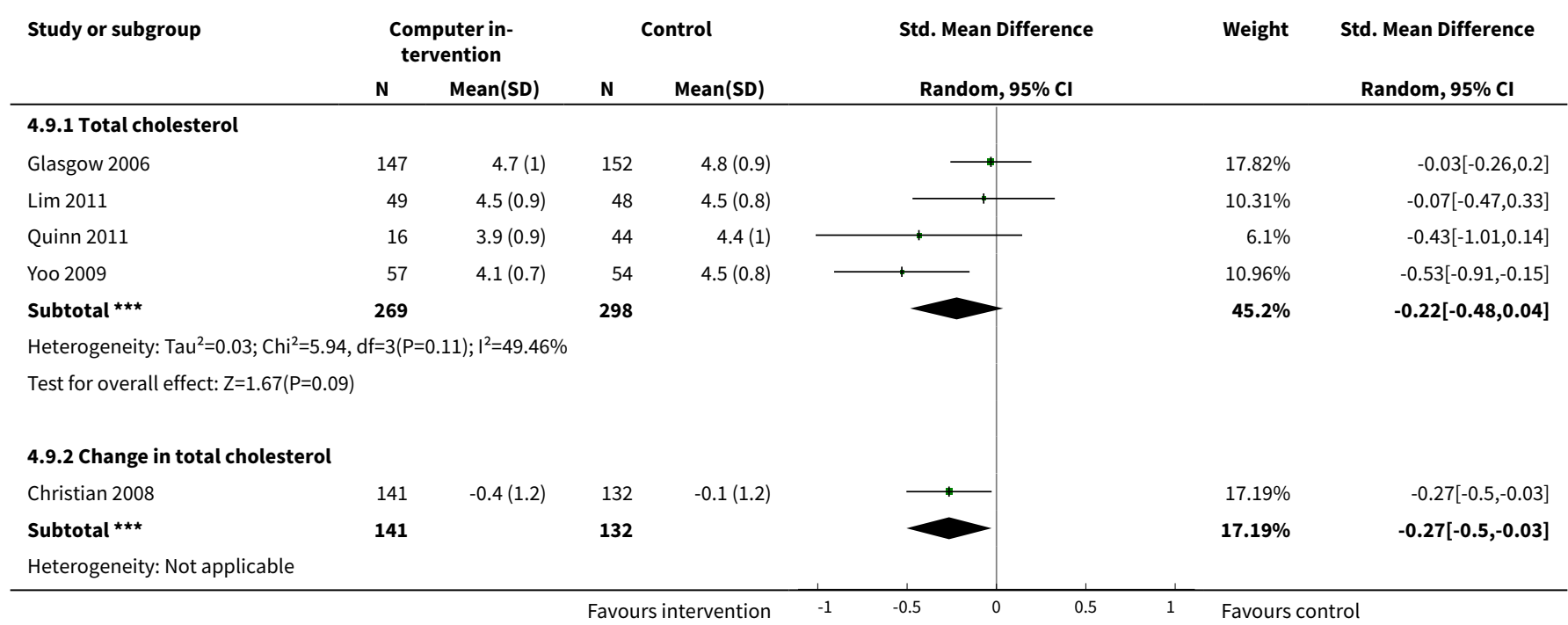




\begin{tabular}{|c|c|c|c|c|c|c|c|}
\hline \multirow[t]{2}{*}{ Study or subgroup } & \multicolumn{2}{|c|}{$\begin{array}{l}\text { Computer in- } \\
\text { tervention }\end{array}$} & \multicolumn{2}{|c|}{ Control } & \multirow{2}{*}{$\begin{array}{c}\text { Std. Mean Difference } \\
\text { Random, } 95 \% \mathrm{Cl} \\
\end{array}$} & \multirow[t]{2}{*}{ Weight } & \multirow{2}{*}{$\begin{array}{l}\text { Std. Mean Difference } \\
\text { Random, } 95 \% \mathrm{Cl}\end{array}$} \\
\hline & $\mathbf{N}$ & Mean(SD) & $\mathbf{N}$ & Mean(SD) & & & \\
\hline \multicolumn{8}{|c|}{ Test for overall effect: $Z=2.18(P=0.03)$} \\
\hline \multicolumn{8}{|c|}{ 4.9.3 Total cholesterol:HDL cholesterol ratio } \\
\hline Glasgow 2005 & 279 & $4.2(1.2)$ & 261 & $4.1(1.2)$ & 7 & $21.11 \%$ & $0.03[-0.14,0.19]$ \\
\hline Glasgow 2010 & 130 & $3.8(1.2)$ & 115 & $3.7(0.9)$ & 7 & $16.51 \%$ & $0.14[-0.11,0.4]$ \\
\hline 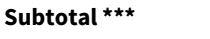 & 409 & & 376 & & & $37.62 \%$ & $0.06[-0.08,0.2]$ \\
\hline \multicolumn{8}{|c|}{ Heterogeneity: $\mathrm{Tau}^{2}=0 ; \mathrm{Chi}^{2}=0.59, \mathrm{df}=1(\mathrm{P}=0.44) ; \mathrm{I}^{2}=0 \%$} \\
\hline \multicolumn{8}{|c|}{ Test for overall effect: $Z=0.88(P=0.38)$} \\
\hline Total $\star \star \star ~$ & 819 & & 806 & & & $100 \%$ & $-0.11[-0.28,0.05]$ \\
\hline \multicolumn{8}{|c|}{ Heterogeneity: $\mathrm{Tau}^{2}=0.02 ; \mathrm{Chi}^{2}=13.9, \mathrm{df}=6(\mathrm{P}=0.03) ; \mathrm{I}^{2}=56.83 \%$} \\
\hline \multicolumn{8}{|c|}{ Test for overall effect: $Z=1.38(P=0.17)$} \\
\hline \multicolumn{8}{|c|}{ Test for subgroup differences: $\mathrm{Chi}^{2}=7.29, \mathrm{df}=1(\mathrm{P}=0.03), \mathrm{I}^{2}=72.55 \%$} \\
\hline
\end{tabular}

\section{ADDITIONAL TABLES}

Table 1. Taxonomy of behaviour change techniques

\section{Behaviour change techniques}

1 Provide information on consequences of behaviour in general

2 Provide information on consequences of behaviour to the individual

3 Provide information about others' approval

4 Provide normative information about others' behaviour

5 Goal setting (behaviour)

6 Goal setting (outcome)

7 Action planning

8 Barrier identification/problem solving

9 Set graded tasks

10 Prompt review of behavioural goals

11 Prompt review of outcome goals

12 Provide rewards contingent on effort or progress towards behaviour

13 Provide rewards contingent on successful behaviour

\section{Shaping}

15 Prompt generalisation of target behaviour 
Table 1. Taxonomy of behaviour change techniques (Continued)

16 Prompt self-monitoring of behaviour

17 Prompt self-monitoring of behavioural outcome

18 Prompt focus on past success

19 Provide feedback on performance

20 Provide information on where and when to perform the behaviour

21 Provide instruction on how to perform the behaviour

22 Model or demonstrate the behaviour

23 Teach to use prompts / cues

24 Environmental restructuring

25 Agree on behavioural contract

26 Prompt practice

27 Use follow-up prompts

28 Facilitate social comparison

29 Plan social support / social change

30 Prompt identification as a role model/position advocate

\section{Prompt anticipated regret}

32 Fear arousal

33 Prompt self-talk

34 Prompt use of imagery

35 Relapse prevention / coping planning

36 Stress management

37 Emotional control training

38 Motivational interviewing

39 Time management

40 General communication skills training

41 Stimulate anticipation of future rewards 
Table 2. Overview of study populations

\begin{tabular}{|c|c|c|c|c|c|c|}
\hline $\begin{array}{l}\text { Character- } \\
\text { istic } \\
\text { Study ID }\end{array}$ & Intervention(s) and control(s) & $\begin{array}{l}{[\mathrm{N}]} \\
\text { Screened }\end{array}$ & $\begin{array}{l}\text { [N] Ran- } \\
\text { domised }\end{array}$ & [N] ITT & $\begin{array}{l}\text { [N] Finish- } \\
\text { ing study }\end{array}$ & $\begin{array}{l}\text { [\%] Ran- } \\
\text { domised } \\
\text { finishing } \\
\text { study }\end{array}$ \\
\hline \multirow{3}{*}{$\begin{array}{l}\text { Christian } \\
2008\end{array}$} & I: computer expert system & T: 322 & I: 155 & - & I: 141 & I: 91 \\
\hline & $\begin{array}{l}\text { C: printed information at baseline then } \\
\text { usual care }\end{array}$ & & C: 155 & & C: 132 & C: 85 \\
\hline & & & $\mathrm{T}: 310$ & & T: 273 & $\mathrm{~T}: 88$ \\
\hline \multirow{3}{*}{$\begin{array}{l}\text { Glasgow } \\
1997\end{array}$} & I: computerised touchscreen assessment & - & I: 108 & No ITT & I: - & I: - \\
\hline & $\begin{array}{l}\text { C: touch screen assessment at baseline } \\
\text { then usual care }\end{array}$ & & C: 98 & $\begin{array}{l}\text { analysis } \\
\text { done }\end{array}$ & C: - & C: - \\
\hline & & & $\mathrm{T}: 206$ & & T: 161 & $\mathrm{~T}: 78$ \\
\hline \multirow{3}{*}{$\begin{array}{l}\text { Glasgow } \\
2003^{a}\end{array}$} & I: D-NET Peer support & - & I: 80 & No ITT & - & - \\
\hline & C: access to articles about diabetes & & C: 80 & $\begin{array}{l}\text { dnalysis } \\
\text { done }\end{array}$ & & \\
\hline & & & $\mathrm{T}: 160$ & & & \\
\hline \multirow{3}{*}{$\begin{array}{l}\text { Glasgow } \\
2005^{b}\end{array}$} & I: DPP & $\mathrm{T}: 1187$ & I: 469 & No ITT & I: 379 & I: 81 \\
\hline & C: touch screen assessment at baseline & & C: 417 & done & C: 354 & C: 85 \\
\hline & & & $\mathrm{T}: 886$ & & T: 733 & $\mathrm{~T}: 83$ \\
\hline \multirow{3}{*}{$\begin{array}{l}\text { Glasgow } \\
2006\end{array}$} & I: TSM & $\mathrm{T}: 2662$ & I: 174 & - & I: 147 & I: 84 \\
\hline & C: enhanced usual care - generic health risk & & C: 161 & & C: 152 & C: 94 \\
\hline & & & $\mathrm{T}: 335$ & & $\mathrm{~T}: 302$ & $\mathrm{~T}: 90$ \\
\hline \multirow{3}{*}{$\begin{array}{l}\text { Glasgow } \\
2010^{C}\end{array}$} & I: CASM & $\mathrm{T}: 544$ & I: 169 & - & I: 130 & I: 77 \\
\hline & $\begin{array}{l}\text { C: enhanced usual care - generic health risk } \\
\text { appraisal then usual care }\end{array}$ & & C: 132 & & C: 115 & C: 87 \\
\hline & & & $\mathrm{T}: 301$ & & $\mathrm{~T}: 245$ & $\mathrm{~T}: 81$ \\
\hline \multirow[t]{3}{*}{ Leu 2005} & I: automated wireless messaging system & $\mathrm{T}: 50$ & I: 25 & $\begin{array}{l}\text { No ITT } \\
\text { analysis }\end{array}$ & I: 21 & I: 82 \\
\hline & C: presumed usual care & & C: 25 & done & $\mathrm{C}: 21$ & C: 82 \\
\hline & & & $\mathrm{T}: 50$ & & $\mathrm{~T}: 42$ & $\mathrm{~T}: 82$ \\
\hline \multirow[t]{3}{*}{ Lim 2011} & I: U-healthcare & $\mathrm{T}: 180$ & I: 51 & No ITT & I: 49 & I: 96 \\
\hline & $\begin{array}{l}\text { C: baseline face-to-face education followed } \\
\text { by usual care }\end{array}$ & & C: 52 & done & $\mathrm{C}: 48$ & C: 92 \\
\hline & & & T: 103 & & $\mathrm{~T}: 97$ & $\mathrm{~T}: 94$ \\
\hline \multirow[t]{3}{*}{ Lo 1996} & I: CAL & - & I: 12 & No ITT & I: 12 & I: 100 \\
\hline & C: group diabetes education sessions & & C: 20 & done & C: 16 & C: 80 \\
\hline & & & $\mathrm{T}: 32$ & & $\mathrm{~T}: 28$ & $\mathrm{~T}: 88$ \\
\hline \multirow[t]{2}{*}{ Lorig 2010} & I: IDSMP & $\mathrm{T}: 1019$ & I: 491 & - & I: 395 & I: 80 \\
\hline & C: usual care & & C: 270 & & C: 238 & C: 88 \\
\hline
\end{tabular}


Table 2. Overview of study populations (Continued)
$\mathrm{T}: 761$
T: 633
T: 83

\begin{tabular}{|c|c|c|c|c|c|c|}
\hline $\begin{array}{l}\text { Quinn } \\
2008\end{array}$ & $\begin{array}{l}\text { I: WellDoc } \\
\text { C: provided blood glucose meters and en- } \\
\text { couraged participants to fax their results to } \\
\text { their healthcare providers every two weeks } \\
\text { until blood glucose was stabilised }\end{array}$ & - & $\begin{array}{l}\text { I: } 15 \\
\text { C: } 15 \\
\mathrm{~T}: 30\end{array}$ & $\begin{array}{l}\text { No ITT } \\
\text { analysis } \\
\text { done }\end{array}$ & $\begin{array}{l}\mathrm{C}: 13 \\
\mathrm{~T}: 26\end{array}$ & $\begin{array}{l}\text { C: } 87 \\
\text { T: } 87\end{array}$ \\
\hline \multirow{3}{*}{$\begin{array}{l}\text { Quinn } \\
2011\end{array}$} & I: group 2 coach only & $\mathrm{T}: 2602$ & I: 38 & - & $\mathrm{I}: 23$ & I: 61 \\
\hline & C: usual care & & C: 63 & & C: 56 & $\mathrm{C}: 90$ \\
\hline & & & $\mathrm{T}: 101$ & & $\mathrm{~T}: 79$ & $\mathrm{~T}: 78$ \\
\hline Smithd & I: Firstclass software & $\mathrm{T}: 50$ & I: 15 & $\begin{array}{l}\text { No ITT } \\
\text { analysis }\end{array}$ & - & I: 100 \\
\hline \multirow[t]{2}{*}{2000} & C: hard copies of materials & & C: 15 & done & & C: 100 \\
\hline & & & $\mathrm{T}: 30$ & & & $\mathrm{~T}: 100$ \\
\hline \multirow[t]{3}{*}{ Wise $1986^{e}$} & & - & - & $\begin{array}{l}\text { No ITT } \\
\text { analysis }\end{array}$ & I: 21 & I: 21 \\
\hline & C: presumed usual care & & & done & $\mathrm{C}: 21$ & C: 21 \\
\hline & & & & & $\mathrm{T}: 42$ & $\mathrm{~T}: 42$ \\
\hline \multirow[t]{3}{*}{ Yoo 2009} & I: UCDC & - & I: 62 & No ITT & $\mathrm{I}: 57$ & I: 92 \\
\hline & C: usual care & & $\mathrm{C}: 61$ & done & C: 54 & C: 86 \\
\hline & & & $\mathrm{T}: 123$ & & $\mathrm{~T}: 111$ & $\mathrm{~T}: 90$ \\
\hline \multirow[t]{3}{*}{ Zhou 2003} & I: Diabetes diet advisor V1.0 & - & I: 88 & - & I: 88 & I: 100 \\
\hline & C: fixed carbohydrate content & & C: 62 & & C: 62 & C: 100 \\
\hline & & & $\mathrm{T}: 150$ & & $\mathrm{~T}: 150$ & $\mathrm{~T}: 100$ \\
\hline \multirow[t]{3}{*}{ Totalf } & All interventions & & 1952 & & 1476 & \\
\hline & All controls & & 1626 & & 1282 & \\
\hline & All interventions and controls & & 3578 & & 2922 & \\
\hline
\end{tabular}

"-" denotes not reported

Where provided, data for analysis has used numbers provided for the specific outcomes. Where these data were not available, numbers in each group have been extracted from CONSORT diagrams or the text of the reports.

$a$ Final numbers for each group were not included in study report. The numbers used in the analysis assumed equal allocation amongst experimental groups and made no allowance for attrition. As this would overpower the study in the meta-analysis, a sensitivity analysis was done removing this study - this had no significant impact on the results.

$\mathrm{b}$ The numbers for the final outcome data did not match the numbers completing the trial. The numbers for control and intervention groups were not provided, only a total $\mathrm{n}$ for number total cases providing outcome data. Numbers in each group were estimated as a proportion of the total cases using the ratio I: $\mathrm{C}=379: 354$, e.g. for HbA1c total $n=560, \mathrm{n}$ for the intervention group $=(379 / 733)^{\star} 560=290$.

c The numbers for the final outcome data did not match the numbers completing the trial. The numbers for control and intervention groups were not provided, only a total $n$ for number total cases providing outcome data. Numbers in each group were based on the CONSORT diagram as there were three groups - CASM, control and CASM+ and trying to estimate the numbers in each group based on the data provided was not feasible.

$\mathrm{d}$ The number of participants completing the study was not reported.

eOnly 2/147 people dropped out of the whole study. 
fRequested data from Glasgow 1997/2003; Smith 2000 and Wise 1986 but no response to queries.

C: control; I: intervention; ITT: intention-to-treat; T: total

\section{APPENDICES}

\section{Appendix 1. Search strategies}

\section{Search terms and databases}

Unless otherwise stated, search terms are free text terms.

Abbreviations:

'\$': stands for any character; '?': substitutes one or no character; adj: adjacent (i.e. number of words within range of search term); exp: exploded MeSH; MeSH:

medical subject heading (MEDLINE medical index term); pt: publication type; sh: MeSH; tw: text word.

\section{The Cochrane Library}

\#1 MeSH descriptor Diabetes mellitus explode all trees

\#2 diabet* in All Text

\#3 (IDDM in All Text or NIDDM in All Text or MODY in All Text or T1DM in All Text or T2DM in All Text or T1D in All Text or T2D in All Text) \#4 ( (non in All Text and insulin* in All Text and depend* in All Text) or (noninsulin* in All Text and depend* in All Text) or ( non in All Text and insulin?depend ${ }^{*}$ in All Text) or noninsulin?depend ${ }^{*}$ in All Text)

\#5 ( (insulin* in All Text and depend* in All Text) or insulin?depend ${ }^{\star}$ in All Text)

\#6 (\#1 or \#2 or \#3 or \#4 or \#5)

\#7 MeSH descriptor Diabetes insipidus explode all trees

\#8 (diabet* in All Text and insipidus in All Text)

\#9 (\#7 or \#8)

$\# 10$ (\#6 and not \#9)

\#11 MeSH descriptor Computer systems explode all trees

\#12 MeSH descriptor Computers explode all trees

\#13 MeSH descriptor Medical informatics explode all trees

\#14 MeSH descriptor Multimedia explode all trees

\#15 MeSH descriptor Therapy, computer-assisted explode all trees

\#16 MeSH descriptor Image Processing, computer-assisted explode all trees

\#17 MeSH descriptor Biomedical Technology explode all trees

\#18 MeSH descriptor Computer-Assisted Instruction explode all trees

\#19 MeSH descriptor Computer communication networks explode all trees

\#20 MeSH descriptor Software explode all trees

\#21 MeSH descriptor Internet explode all trees

\#22 MeSH descriptor Hypermedia explode all trees

\#23 MeSH descriptor Telemedicine explode all trees

\#24 MeSH descriptor Video recording explode all trees

\#25 MeSH descriptor Drug therapy, computer-assisted explode all trees

\#26 MeSH descriptor User-computer interface explode all trees

\#27 MeSH descriptor Medical records systems, computerized explode all trees

\#28 MeSH descriptor Cellular phone explode all trees

\#29 MeSH descriptor Remote consultation explode all trees

$\# 30$ (\#11 or \#12 or \#13 or \#14 or \#15 or \#16 or \#17 or \#18 or \#19 or \#20 or \#21 or \#22 or \#23 or \#24 or \#25 or \#26 or \#27 or \#28 or \#29)

\#31 (computer-assist* in All Text near/6 therap* in All Text)

\#32 (computer-assist* in All Text near/6 treatment ${ }^{*}$ in All Text)

\#33 (computer-assist* in All Text near/6 education* in All Text)

\#34 (computer-based in All Text near/6 therap* in All Text)

\#35 (computer-based in All Text near/6 treatment* in All Text)

\#36 (computer-based in All Text near/6 education* in All Text)

\#37 (web-based in All Text near/6 therap* in All Text) 
(Continued)

\#38 (web-based in All Text near/6 treatment* in All Text)

\#39 (web-based in All Text near/6 education* in All Text)

\#40 (computer* in All Text or Internet in All Text or hypermedia* in All Text or telecommunication* in All Text)

\#41 (interactive in All Text or online in All Text or on-line in All Text or telemedicin* in All Text or tele-medicin* in All Text or (video in

All Text and record* in All Text)

or (cellular in All Text and phon* in All Text) or (mobil* in All Text and phon* in All Text))

\#42 (multimedia* in All Text or multi-media* in All Text)

\#43 (cd-rom in All Text or compact-disc* in All Text)

\#44 ( (world in All Text and wide in All Text and web in All Text) or (worldwide in All Text and web in All Text) or website* in All Text)

\#45 (electronic in All Text and health* in All Text)

\#46 (\#30 or \#31 or \#32 or \#33 or \#34 or \#35 or \#36 or \#37 or \#38 or \#39 or \#40 or \#41 or \#42 or \#43 or \#44 or \#45)

$\# 47$ (\#10 and \#46)

\section{MEDLINE}

1. exp Diabetes Mellitus/

2. diabet\$.tw,ot.

3. (IDDM or NIDDM or MODY or T1DM or T2DM or T1D or T2D).tw,ot.

4. (non insulin\$ depend\$ or noninsulin\$ depend\$ or non insulin?depend\$ or noninsulin?depend\$).tw,ot.

5. (insulin\$ depend\$ or insulin?depend\$).tw,ot.

6. exp Diabetes Insipidus/

7. diabet\$ insipidus.tw,ot.

8. or/1-5

9.6 or 7

10. 8 not 9

11. exp Computer systems/

12. exp Computer/

13. exp Medical Informatics/

14. exp Multimedia/

15. exp Therapy, Computer-Assisted/

16. exp Image Processing, Computer-Assisted/

17. exp Biomedical Technology/

18. exp Computer-Assisted Instruction/

19. exp Computer communication networks/

20. exp Software/

21. exp Internet/

22. exp Hypermedia/

23. exp Telemedicine/

24. exp Video recording/

25. exp Drug Therapy, Computer-Assisted/

26. exp User-Computer Interface/

27. exp Medical Records Systems, Computerized/

28. exp Cellular phone/

29. exp Remote consultation/

30. ((computer-assist* or computer-based or web-based) adj6 (therap* or treatment* ${ }^{\star}$ or education $\left.\left.{ }^{\star}\right)\right)$.tw,ot.

31. (computer ${ }^{\star}$ or Internet or hypermedia* or telecommunication*).tw,ot.

32. (interactive or online or on-line or telemedicin* or video record ${ }^{\star}$ or cellular phon ${ }^{\star}$ or mobil ${ }^{\star}$ phon*).tw,ot.

33. (multi-media or multimedia).tw,ot.

34. (cd-rom or compact-disc $\left.{ }^{\star}\right)$.tw, ot.

35. (world wide web or worldwide web or website $\left.{ }^{\star}\right)$.tw,ot.

36. electronic health*.tw,ot.

37. or/11-36

38. randomised controlled trial.pt.

39. controlled clinical trial.pt.

40. randomi?ed.ab.

41. placebo.ab.

42. drug therapy.fs.

43. randomly.ab.

44. trial.ab.

45. groups.ab. 
(Continued)

46. or/38-45

47. Meta-analysis.pt.

48. exp Technology Assessment, Biomedical/

49. exp Meta-analysis/

50. exp Meta-analysis as topic/

51. hta.tw,ot.

52. (health technology adj6 assessment\$).tw,ot.

53. (meta analy\$ or metaanaly\$ or meta?analy\$).tw,ot.

54. ((review\$ or search\$) adj10 (literature\$ or medical database\$ or medline or pubmed or embase or cochrane or cinahl or psycinfo or psyclit

or healthstar or biosis or current content\$ or systemat\$)).tw,ot.

55. or/47-54

56. (comment or editorial or historical-article).pt.

57.55 not 56

58. 46 or 57

59. 10 and 37 and 58

\section{EMBASE}

1. exp Diabetes Mellitus/

2. diabet\$.tw,ot.

3. (non insulin ${ }^{\star}$ depend $^{\star}$ or noninsulin ${ }^{\star}$ depend $^{\star}$ or non insulin?depend ${ }^{\star}$ or noninsulin?depend ${ }^{\star}$ ).tw,ot.

4. (insulin* depend ${ }^{\star}$ or insulin?depend ${ }^{\star}$ ).tw,ot.

5. (IDDM or NIDDM or MODY or T1DM or T2DM or T1d or T2D).tw,ot.

6. or/1-5

7. exp Diabetes Insipidus/

8. diabet $^{\star}$ insipidus.tw,ot.

9. 7 or 8

10.6 not 9

11. exp computer/

12. exp medical informatics/

13. exp multimedia/

14. exp computer assisted therapy/

15. exp image processing/

16. exp medical technology/

17. exp teaching/

18. exp information processing/

19. exp telemedicine/

20. exp videorecording/

21. exp computer interface/

22. exp medical record/

23. exp mobile phone/

24. exp teleconsultation/

25. ((computer-assist ${ }^{\star}$ or computer-based or web-based) adj6 (therap ${ }^{\star}$ or treatment ${ }^{\star}$ or education $\left.{ }^{\star}\right)$ ).tw,ot.

26. (computer ${ }^{\star}$ or Internet or hypermedia* or telecommunication ${ }^{\star}$ ).tw,ot.

27. (interactive or online or on-line or telemedicin* or video record ${ }^{\star}$ or cellular phon* or mobil ${ }^{\star}$ phon ${ }^{\star}$ ).tw,ot.

28. (multi-media* or multimedia*).tw,ot.

29. (cd-rom or compact-disc $\left.{ }^{\star}\right)$.tw,ot.

30. (world wide web or worldwide web or website*).tw,ot.

31. electronic health*.tw,ot.

32. or/11-31

33. 10 and 32

34. exp Randomized Controlled Trial/

35. exp Controlled Clinical Trial/

36. exp Drug comparison/

37. exp Randomization/

38. exp Crossover procedure/

39. exp Double blind procedure/

40. exp Single blind procedure/

41. exp Prospective Study/ 
(Continued)

42. (random\$ adj6 (allocat\$ or assign\$ or basis or order\$)).ab,ti.

43. ((singl\$ or doubl\$ or trebl\$ or tripl\$) adj6 (blind\$ or mask\$)).ab,ti.

44. (cross over or crossover).ab,ti.

45. or/34-44

46. exp meta analysis/

47. (metaanaly\$ or meta analy\$ or meta?analy\$).ab,ti,ot.

48. ((review\$ or search\$) adj10 (literature\$ or medical database\$ or medline or pubmed or embase or cochrane or cinahl or psycinfo or psyclit

or healthstar or biosis or current content\$ or systematic\$)).ab,ti,ot.

49. exp Literature/

50. exp Biomedical Technology Assessment/

51. hta.tw,ot.

52. (health technology adj6 assessment\$).tw,ot.

53. or/46-52

54. 45 or 53

55.33 and 54

56. limit 55 to human

57. (comment or editorial or historical-article).pt.

58.56 not 57

\section{PsycINFO}

1. exp Diabetes Mellitus/

2. diabet\$.tw,ot.

3. (IDDM or NIDDM or MODY or T1DM or T2DM or T1D or T2D).tw,ot.

4. (non insulin\$ depend\$ or noninsulin\$ depend\$ or non insulin?depend\$ or noninsulin?depend\$).tw,ot.

5. (insulin\$ depend\$ or insulin?depend\$).tw,ot.

6. exp Diabetes Insipidus/

7. diabet\$ insipidus.tw,ot.

8. or/1-5

9. 6 or 7

10.8 not 9

11.exp Multimedia/

12.exp Computer-Assisted Instruction/

13.exp Internet/

14.exp Hypermedia/

15.exp Telemedicine/

16.exp Cellular phone/

17.((computer-assist ${ }^{\star}$ or computer-based or web-based) adj6 (therap* or treatment ${ }^{\star}$ or education $\left.\left.{ }^{\star}\right)\right)$.tw,ot.

18. (computer ${ }^{\star}$ or Internet or hypermedia* or telecommunication $\left.{ }^{\star}\right)$.tw,ot.

19. (interactive or online or on-line or telemedicin* or video record ${ }^{\star}$ or cellular phon* or mobil* phon ${ }^{\star}$ ).tw,ot.

20.(multi-media or multimedia).tw,ot.

21.(cd-rom or compact-disc $\left.{ }^{\star}\right)$.tw,ot.

22.(world wide web or worldwide web or website $\left.{ }^{\star}\right)$.tw,ot.

23.electronic health ${ }^{*}$.tw,ot.

24.or/11-23

25.randomi?ed.ab.

26. placebo.ab.

27.randomly.ab.

28.trial.ti.

29.or/25-28

30.exp Meta-analysis/

31.hta.tw,ot.

32.(health technology adj6 assessment\$).tw,ot.

33. (meta analy\$ or metaanaly\$ or meta?analy\$).tw,ot.

Computer-based diabetes self-management interventions for adults with type $\mathbf{2}$ diabetes mellitus (Review)

Copyright (c) 2013 The Cochrane Collaboration. Published by John Wiley \& Sons, Ltd. 
(Continued)

34.((review\$ or search\$) adj10 (literature\$ or medical database\$ or medline or pubmed or embase or cochrane or cinahl or psycinfo or psyclit

35.or healthstar or biosis or current content\$ or systemat\$)).tw,ot.

36.or/30-34

37.29 or 35

38.10 and 24 and 36

\section{Web-of-Science}

\#1 Title=(diabet $\left.{ }^{\star}\right)$ OR Title=(insulin ${ }^{\star}$ depend $\left.^{\star}\right)$ OR Title=(non insulin ${ }^{\star}$ depend $\left.^{\star}\right)$ OR Title=(IDDM) OR Title=(NIDDM) OR Title=(T1DM) OR Title=(T2DM) AND Topic $=(T 1 D)$ AND Topic $=(T 2 D)$

\#2 Topic=(computer $\left.{ }^{\star}\right)$ OR Topic=(multimedia) OR Topic=(web-based) OR Topic=(Internet) OR Topic=(telecommunication $\left.{ }^{\star}\right)$ OR Topic=(electronic-health)

OR Topic $=($ hypermedia* $)$ OR Topic $=\left(\right.$ website $\left.^{\star}\right)$ OR Topic $=\left(\right.$ interactiv $\left.^{\star}\right)$ OR Topic=(online) OR Topic=(cellular phon $\left.{ }^{\star}\right)$

\section{\#3 \#2 AND \#1}

\#4 Topic $=\left(\right.$ random $\left.^{\star}\right)$ OR Topic $=($ controlled clinical trial $)$ OR Topic $=\left(\right.$ random $\left.^{\star}\right)$ OR Topic $=\left(\right.$ clinical trial $\left.{ }^{\star}\right)$ OR Topic $=\left(\right.$ meta-analys $\left.{ }^{\star}\right)$ OR Topic=(hta)

\#5 \#4 AND \#3

\section{CINAHL}

1. exp DIABETES MELLITUS/

2. diabet ${ }^{\star}$.af

3. (IDDM OR NIDDM OR MODY OR T1DM OR T2DM OR T1D OR T2D).ti,ab

4. ("non insulin* depend*" OR "noninsulin* depend*" OR "non insulin* depend*" OR "noninsulin* depend*").ti,ab

5. ("insulin* depend").ti,ab

6. exp DIABETES INSIPIDUS/

7. ("diabet* insipidus").ti,ab

8. 1 OR 2 OR 3 OR 4 OR 5

9. 6 OR 7

10.8 not 9

11.exp COMPUTER SYSTEMS/

12.exp MEDICAL INFORMATICS/

13.exp MULTIMEDIA/

14.exp THERAPY, COMPUTER ASSISTED/

15. exp IMAGE PROCESSING, COMPUTER ASSISTED/

16. $\operatorname{exp~COMPUTER~ASSISTED~INSTRUCTION/~}$

17. $\exp$ COMPUTER COMMUNICATION NETWORKS/

18.exp SOFTWARE/

19.exp INTERNET/

20.exp HYPERMEDIA/

21.exp TELEMEDICINE/

22.exp VIDEORECORDING/

23.exp DRUG THERAPY, COMPUTER ASSISTED/

24.exp USER-COMPUTER INTERFACE/

25.exp COMPUTERIZED PATIENT RECORD/

26.exp REMOTE CONSULTATION/

27. (computer* OR Internet OR hypermedia* OR telecommunication).ti,ab

28. (interactive OR online OR on-line OR telemedicin* OR video OR record* OR "cellular phon*" OR "mobil* phon*").ti,ab 29.(multi-media OR multimedia).ti,ab 
(Continued)

30.(cd-rom OR compact-disc $\left.{ }^{\star}\right)$.ti,ab

31. ("world wide web" OR "worldwide web" OR "website*").ti,ab

32. ("electronic health*").ti,ab

33.11 OR 12 OR 13 OR 14 OR 15 OR 16 OR 17 OR 18 OR 19 OR 20 OR 21 OR 22 OR 23 OR 24 OR 25 OR 26 OR 27 OR 28 OR 29 OR 30 OR 31 OR 32

34."clinical trial".pt

35.random*.ti,ab

36.placebo.ti,ab

37.trial.ti,ab

38.34 OR 35 OR 36 OR 37

39."technology assessment".ti,ab

40.exp META ANALYSIS/

41.hta.ti,ab

42.("health technology assessment $\left.{ }^{\star} "\right) . t i, a b$

43. ("meta analy*" OR metaanaly*).ti,ab

44. ((review* OR search $\left.{ }^{\star}\right)$ AND (literature* OR medical database* OR medline OR pubmed OR embase OR cochrane OR cinahl OR psycinfo OR psyclit

45.OR healthstar OR biosis OR current content* OR systemat*)).ti,ab

46.39 OR 40 OR 41 OR 42 OR 43 OR 44

47.("editorial" OR "historical material" OR "commentary").pt

48.45 not 46

49.38 OR 47

50.10 AND 33 AND 48

\section{Appendix 2. Description of interventions}

\begin{tabular}{lll}
\hline Characteristic & $\begin{array}{l}\text { Intervention(s) } \\
\text { [duration, intensity, frequency] }\end{array}$ \\
Study ID & & Control(s) \\
[duration, intensity, \\
frequency]
\end{tabular}

Christian 2008 A computer-based assessment of their motivational readiness to increase physical activity and make dietary changes.

The program solicited information on usual dietary habits and awareness of the role of diet and exercise in the management of diabetes.

On completion of the assessment, the computer expert system generated a 4- to 5-page individualised, tailored report, which provided feedback addressing participant-identified barriers to improving their physical activity and diet.

One 10 minute assessment and then 4 meetings with physicians for 12 months.
Patients were given a packet of health education materials at the baseline visit addressing diabetes, diet and exercise. Therafter, they completed their regular clinic visit with their usual physician but had no additional prompts or motivational interviewing from their physicians regarding their specific goals for weight or physical activity other than what they might receive during usual care. Three monthly visits at 0, 3, 6, 9 and 12 months.

Glasgow $1997 \quad$ Initial assessment the same as control group. In addition, patients completed a 5-10 minutes touch screen dietary barriers assessment that immediately generated two printed feedback forms:

(1) for the patient, likely problem situations to plan for concerning diet and
Computerised assessment via touch screen variables assessed were: 
(2) an assessment summary for the physician. Patients with higher self-efficacy levels received a "take-home" video that addressed strategies for the most frequent type of barriers they experienced. Patients with lower self-efficacy levels returned for a 30 minute interactive video, operated via touch screen system. Telephone follow-up at 1 and 3 weeks provided an opportunity to review patient progress. This intervention sequence was repeated at a 3-month follow-up visit. At 6 months, participants received a final phone call and at 9 months a copy of the book "The human side of diabetes".

Duration: 6 months. Intensity: 5 minutes. Frequency: baseline and 3 months.
1. Dietary stage of change

2. Summary of Diabetes Self-Care scale

3. Brief 3- or 4-item scales to assess personal models of diabetes

4. Beliefs about the seriousness of diabetes and importance of treatment 5. Desire for participation in diabetes management through shared control scale of the Multidimensional Desire for Control Scales

6. Weight

7. Food habits questionnaire

8. HbA1c and cholesterol.

Duration: 12 months. Intensity: 30 minutes. Frequency: baseline, 3 and 12 months.

Participants in the Information Only condition had computer access to an extensive number of articles on topics of medical, nutritional, and lifestyle aspects of diabetes. All these articles gave information only and did not systematically instruct participants or provide individually tailored recommendations for changing dietary practices or other behaviours. They also completed assessments on-line and received automated dietary change goals based upon their current dietary levels. Each participant received in-home training in use of the computer of approximately two to three visits of $1-2 \mathrm{~h}$ each.

Duration: 10 months. Intensity: not stated. Frequency: not stated.

Touch screen computer: Participants were asked 
ciation/ National Committee for Quality Assurance Provider Recognition Program measures as in the control group; Part 2 involved a self-management action plan for diet, activity and smoking, summary of goals and assays due, 1-page printout, care-manager review and brief follow-up.

Duration:12 months. Intensity: 30 minutes. Frequency: 6 monthly. to recall when they last received the 11 diabetes care items contained in the American Diabetes Association/ National Committee for Quality Assurance Provider Provider Recognition Program measures and general; health risk issues (e.g., use of seatbelts, cancer screening) and given printout of general risks.

Duration: 12 months. Intensity: 30 mins. Frequency: 6 monthly.

Enhanced Usual Care: The usual care comparison group received computer-assisted generic health risk appraisal and feedback.

Duration: 2 months. Intensity: not stated. Frequency: not stated.

\section{Glasgow 2010}

\begin{abstract}
1) The computer presented a comprehensive list of benefits of and barriers to healthy eating and being physically active, and patients were allowed to write in their own benefits and barriers if they did not find one that suited them. The program next produced lists of suggested strategies tailored to the individual's identified barriers. Then participants were asked to rate their self-efficacy or confidence in; achieving the goals and carrying out the strategies delineated in their action plans. If a participant rated self-efficacy at less than 7 on the 10-point scale, the computer program encouraged revision of the plan.
\end{abstract}

2) The plan was then translated by the computer program into a printout that was used as a tool for dialogue between the patient and their health coach.

3) At approximately 1 week and 1 month after the first visit, participants received a follow-up call, averaging 10-15 min, from their health coach to review their goals, barriers, and strategies, and reinforce or revise their plan as appropriate.

4) A tailored health newsletter was also mailed approximately 6 weeks after the first visit.

Duration: 2 months. Intensity: not stated, 10-15 mins for phone call. Frequency: once for computer, twice for phone calls, also letter (once) first visit (once)

CASM participants were given access to the "My Path to Healthy Life"/"Mi Camino A La Vida Sana" website and instructed in website log-in, navigation, and usage by a research staff member. Participants were asked to select initial, easily achievable goals in each of three areas: medication adherence, exercise, and food choices. They recorded their progress on these three daily goals using the tracking section of the website and received immediate feedback on success meeting their goals over the past 7 days. The website included a graphical display of the patient's haemoglobin A1c, blood pressure, and cholesterol results; moderated forum; and community resources (e.g., healthful recipes, printable handouts) for DSM and healthy lifestyles, as well as features to enhance user engagement, such as rotating quiz questions and motivational tips.; after 6 weeks, participants created new personalised goals and "action plans" for medication taking, healthy eating, and PA. For each of the three areas, users identified barriers to achieving the (revised) goal(s) they had selected, and then chose from a list of problem-solving strategies to overcome those barriers. Each user's action plan summary was available for easy reference and/or revision.
Enhanced Usual Care (EUC) provided computer-based health risk appraisal feedback and recommended preventive care behaviours using the same contact schedule as CASM, but did not include the key intervention procedures. EUC participants, as well as CASM and

CASM + SS participants, were eligible to participate in other traditional DSM education, such as education classes, weight loss groups, or case management avail- 
In addition to the website, CASM participants received periodic prompting using a computer-based telephone system that initiated outbound calls, received inbound calls, provided motivational information, and collected data. able to Kaiser Permanente Colorado (KPCO) members, but very few did so during the study.

Presumed usual care.

\section{Leu 2005}

Patients in the pager group received instructions on pager use. They were asked to demonstrate how to use the pager, and then were asked about the messages that they desired (text, frequency, and time at which the message should be sent). As determined by a previous study, 9 appointment reminders, medication reminders, blood glucose testing reminders, exercise reinforcement, dietary reinforcement, meal time reinforcement, and laboratory result reporting were offered. Custom reminders were supported, including reminders for the time of day ("It's 3:00-ish!") and reinforcement for other health-related tasks ("Time for water."). Birthdays were noted. The patients received contact information, including the number of the investigator, the pager number, the number of the University of Washington Physician's Network clinic, and instructions to dial 911 for emergencies. The patients were taken to the laboratory, and the messaging system was configured.

Duration:patients in the experimental group were enrolled an average of 153 days. Intensity: on average 3.2 messages per day. Frequency: daily.
Diabetes education provided at baseline. The u-healthcare group was educated to use public switched telephone network-connected glucometer to measure their blood glucose level at least 8 times a week ( $\geq 3$ at fasting, $\geq 3$ postprandial, and $\geq 2$ bedtimes) and to start short message service (SMS) on their mobile phone to receive messages from the CDSS rule engine server. Additional education was provided to help patients with its usage and message interpretation. All patients visited the outpatient clinic every 3 months for an interview conducted by their physician and provided a blood sample.

After glucose levels were measured, the GlucoDr Supersensor glucometer was placed onto its own cradle, after which all of the tested data were automatically transferred and stored in the database of the remote data collection server. These data were evaluated by the CDSS to generate patient-specific messages. CDSS-generated messages were sent to the patient's mobile phone within 2 minutes of data transfer.

The patient's anthropometry, blood pressure, current blood glucose and A1C levels, and current medication were simultaneously uploaded from the hospital's electronic medical record (EMR) server to the u-healthcare server. Personal information, including diet and exercise, was also collected and stored on the server to provide appropriate individualized service. Information from the patient's glucometer was automatically sent to the server, after which instructions that were appropriate and specific for each patient were generated by the CDSS rule engine. The CDSS rule engine is based on the clinical practice recommendations of the American Diabetes Association and the Korean Diabetes Association. In addition to providing messages as a response to the patient's glucose testing, the CDSS rule engine also generated evaluation messages on each patient's the weekly and monthly average glucose levels. These messages were sent on Mondays and Tuesdays, respectively. To ensure compliance with frequent glucose testing (at least 8 times/week), evaluation messages on the total number of weekly glucose measurements were also sent on Wednesdays as a reminder.

Duration: 6 months. Intensity: Received messages within 2 minutes of uploading blood glucose data. Frequency: Recommended frequency at least 11 times a week.
Provided pertinent diabetes education, including a therapeutic lifestyle change program, to standardise every patient's education level and practice of diabetes management. After the education, individuals in the control group did not receive an intervention and were advised to follow-up according to their current medical care. All patients visited the outpatient clinic every 3 months for an interview conducted by their physician and provided a blood sample. 


\section{Lo 1996}

Sixteen computerised lessons each dealing with $1 / 2$ aspects of management. Lessons included: introduction to diabetes, treatment of diabetes part 1 carbohydrates in the diet, treatment of diabetes part 2 - complications of diabetes, complications of diabetes part 1 -exchanging diet portions, complications of diabetes part 2 - preventing complications, protein and understanding food labels, exercise and diabetes, sexuality pregnancy and diabetes, eating out, blood and urine testing, insulin injections, alcohol and diabetes, travelling and diabetes. Each learning objective is displayed, then explained in more detail, then followed by a test, patients cannot progress through the lesson until they have passed the test. At the end of each lesson there is a multiple choice revision test, and the patient can only exit the lesson once they have passed the test.

Duration: Not stated. Intensity: 1 hour. Frequency: 3-6 sessions, on average 4.
Conventional diabetes education sessions as one group , four sessions of between 2 and a half to 3 hours conducted weekly by diabetes educators and dieticians who used audio-visual aids and printed materials to reinforce learning.

Duration: 1 month. Intensity: $2.5-3$ hours. Frequency: once weekly for 4 sessions.

\section{Lorig 2010}

\begin{abstract}
1) The Learning Center, where the program content is offered in 20-30 new Web pages weekly. Each week, participants are asked to reply to a question such as "What problems do you have because of your diabetes?" and to make a specific action plan. The questions and action plans are posted on bulletin boards in the 2) Discussion Center, where they can be seen by all participants. The Discussion Center is made up of four interactive threaded bulletin boards (Action Planning, Problem Solving, Difficult Emotions, and Celebrations) populated by responses made in the Learning Center, as well as new threads started by participants whenever they wish. A typical program of 2025 participants results in 500 or more posts.

3) My Tools consists of exercise and medication logs, audio relaxation exercises, meal planning, and glucose-monitoring tools and links to other diabetes-related websites.

4) Post Office is a section where participants and facilitators can write private, individual messages to each other.

5) Help is a section where participants can e-mail the moderators or program administrators. The latter is also available via a toll-free telephone line. In addition to the Web program, each participant received a copy of the book. 6) Living a Healthy Life with Chronic Conditions. Specific sections of this book are referenced in the Learning Center.

7) Reinforcement - a list serve peer support discussion group.
\end{abstract}

Duration: 6 weeks. Intensity: not stated. Frequency: not stated.
Usual-care participants were not restricted from seeking additional care or programs.

Duration: 6 weeks. Intensity: not stated. Frequency: not stated.

\section{Quinn 2008}

The WDS is designed to serve as a virtual coach for patients and a virtual endocrinologist for HCPs, facilitating the coordination of diabetes care among existing resources. The primary areas of focus during this 3-month trial were to test the WDS's ability:

(1) to teach patients about dietary impacts on BG levels,

(2) to direct patients to generate higher-quality BG data, and

(3) to determine the effect of provided patient BG data, data analysis, and suggested therapy recommendations on HCP prescribing behaviour.

The patient communication system used a One Touch Ultra BG meter, Bluetooth-adapted such that when the patient removed the test strip out of the BG meter, the patient's BG value would be wirelessly, securely, and automatically sent to the patient's cell phone. Cell phones used for the trial were either Nokia 6682 or Nokia 6680. Patient data were uploaded from the web server into the cell phone and integrated into the cell phone-based software, DiabetesManager, for personalised feedback.

Duration: 12 months. Intensity: not stated. Frequency: not stated.
At baseline, all patients completed the Summary of Diabetes Self-Care Activities (SDSCA) questionnaire and had an A1C and complete medical and demographic history obtained by the research team. Patients randomised to the control group received One Touch Ultra ${ }^{\mathrm{TM}}$

BG meters (LifeScan, Milpitas, $C A$ ) and adequate BG testing strips and lancets for the duration of the trial. They were asked to fax or call in their BG logbooks every 2 weeks to their HCPs un- 
til their BG levels were stabilized in the target ranges or until their HCPs changed testing frequency. Investigators asked treating HCPs to follow their usual standards of care for the patients' diabetes management.

Duration: 3 months. Intensity: not stated. Frequency: up to fortnightly calls/faxes to research team.

\section{Quinn 2011}

Patients selected one of two mobile phone models, received a one-year unlimited mobile phone data and phone service plan, received the study treatment phone software, and had access to the web-based individual patient portal. All patients in the intervention group were given system-driven guidance on when to test their BG based on their disease status, medication regimen, and time of poorest control (for example, pre prandial versus postprandial) so that the most useful, patient-specific multi-point BG profile was created and used for data analysis and self-management coaching for the patient. For quality assurance, diabetes educators and endocrinologists periodically reviewed patients' electronic logbook data and the summary analysis reports, generated for patients and physicians. After random treatment assignment, patients in the; intervention groups were risk stratified by the coaching system based on comorbidities, complexity of medication regimen and diabetes status. This risk-stratification was used to direct the level of diabetes educator interaction with patients. Those patients who were determined highest risk level were contacted by a diabetes educator via the web-based messaging centre, at most, four times a month. Other patients received communication updates every 2-3 months. These communications were directed by patterns in patient data and focus on such topics as selfmanagement skills, blood glucose control, and medication adherence. The majority of the patient communication was delivered by automated feedback on the mobile phone and messaging through the message centre in the patient web portal. If the content material had not been created at the time a particular patient problem had been identified that needed to be addressed, a diabetes educator wrote a message to the patient. This material was then catalogued by the coaching system and added for future automation. Outbound patient phone calls by the educators were discouraged and limited to those patients who displayed high-risk glycaemic patterns (i.e., repeat severe hypoglycaemia) or who requested to be contacted by phone for self-management issues. Patients received the coaching software system on the mobile phone. Patients entered BG data, carbohydrates consumed, diabetes medications taken, and miscellaneous comments regarding diabetes self-care. "Just-in-time" (real-time) messaging was sent to the patient's mobile phone providing feedback on the entered data. The feedback was driven by the values of the patient's data, the trend of any recently entered data and the physician's medication instructions for each patient. Entered data were captured in real-time in the web-based logbook. Patients could provide their PCPs with printed copies of their electronic logbooks and other information. Patient action plans summarizing the patient entered data and identifying possible self-management actions for improving their diabetes control were electronically sent to the patients every 2.5 months. Each patient was instructed that action plans also serve as a pre-visit summary for the patient's next office visit to their PCP.
Patients receive a One Touch Ultra $2^{\mathrm{TM}}$ (LifeScan, Milpitas, CA) glucose meter and supplies for a year. Patients were told to use the glucose meter as recommended by their physicians. Patients provided SMBG information based on their individual physicians' instructions, including the physician practice option to download SMBG from the study patient glucose meter. Primary Care Providers provided care as usual. Providerdriven care, based in office, no special diabetes management.

Duration: 12 months. Intensity: not stated. Frequency: not stated. 
Duration: 12 months. Intensity: Real-time (instant response) to patient entered data. Frequency: variable - determined by needs of patient. Diabetes educators contacted patients a maximum of 4 times a month, but usually every 2-3 months. Patient action plans sent out every 10 weeks.
Everyone in the computer group was trained how to use the software and those who didn't have computers were loaned laptop computers. The software consisted of 4 components:

1) "Conversation" - the women were encouraged to converse with each other about anything, this area functioned much like a support group, exchanges were monitored daily by the Community Diabetes educator nurse monitor, but she did not actively participate unless directly invited.

2) "Mailbox" - women could email each other or the nurse monitor privately. 3) "Health chat" - was en education platform, like an "electronic classroom", questions specific to diabetes and articles from the Health Information notebook were discussed, the nurse monitor took an active role in this.

4) "Resource rack" - functioned as a "bulletin board" where project team posted items of interest to people with diabetes, it was a read-only feature.

Duration: 5 months. Intensity: variable. Frequency: variable.

Only subgroup IV included in this review:

ICT+KAP. ICT: interactive computer teaching program consists of sequences of text and animated graphics dealing with general diabetes concepts, hypoglycaemic drug action, glucose control, blood and urine monitoring, complications, diet and foot care. Each teaching program used the principle of questioning after each provision of fact, followed either by optional or compulsory rerun of the fact sequence if inadequate performance was recorded for any subject. 45-60 mins to complete.

The KAP was used in arms II, III, IV of the trial (at baseline and 4-6 months) and consists of multiple-choice questions dealing with all major topics covered by the ICT programme - general diabetes concepts, hypoglycaemic drug action, glucose control, blood and urine monitoring, complications, diet and foot care. Responses are automatically scored and filed on disk for later analysis; a printout can be automatically generated on conclusion, giving the score and corrective feedback on options omitted or incorrectly answered in the form of a personalised listing.

$\mathrm{NB} /$ in arm II of the trial participants weren't given the feedback printout, in arm III of the trial participants were given the printout, and in arm IV they weren't given the printout but did the ICT (see below) 1 week after the first KAP.

Duration: 6 months. Intensity: ICT 45-60 mins, KAP 20-40 mins. Frequency: ICT once, KAP twice.

\section{Yoo 2009}

1. Alarm on cell phone for twice daily blood pressure and glucose measurement, once daily weight and exercise: automated replies with advice.

2. Text messages to phone about exercise. 3. Three text messages a day about lifestyle advice. 4. Physician tailored advice.

Duration: 12 weeks. Intensity: variable. Frequency: > 3 times a day.
Hard copies of all the materials given to intervention group including a notebook of health information regarding women's health in general and specific diabetes information (with special attention to its effects on women).

Duration: 5 months. Intensity: variable. Frequency: variable.

"Unaware of the study" and evaluation of only HbAlc.

Duration: 4-6 months.

Patients in the control group visited their clinic according to their routine schedule and received the usual outpatient treatment from their physicians during the study period. During the trial, drug dosage was not changed in either the UCDC or the control groups at either location.

Duration: 12 weeks. 
(Continued)

Zhou 2003
Computer assisted nutrition therapy group (test group) 88 samples, using the dietary therapy from 'Diabetes diet advisor V1.0', three plans every time, patients consume food according to the plans. Operation of 'Diabetes diet advisor V1.0' : patients input their personal details (name, sex, age, height, weight, fitness and other complications), select the food types of breakfast, lunch and dinner (there are 26 types of food in total), put them into each meal respectively, then click 'select menu'. The computer processes according to the basic information of the patients. The screen displays the dietary plan after the process. If the patients do not accept the dietary plan, they can click 'manual adjustment'. Interaction takes place between the patient and the computer, selecting suitable dietary plan directly. For this software, the patients select the food types according to their individual choice, the quantity of food is determined from the interaction between the computer and the patient. Therefore, most type 2 diabetic patients accept the dietary plan from the computer. They do not just follow the dietary plan continuously, but also feel the software increased the controllability of nutrition therapy.

Duration: 8 weeks. Intensity: not stated, 2 weekly follow-up. Frequency: not stated.
Fixed carbohydrate content group - the daily caloric intake, the ratio of carbohydrate, protein and fat and the amount of principle food are decided by the doctor.

Duration: 8 weeks. Intensity: not stated, 2 weekly follow-up. Frequency: not stated.

\section{Footnotes}

BG: blood glucose; CASM: self-administered, computer-assisted self-management; CASM+SS: self-administered, computer-assisted self-management with the addition of enhanced social support; CDSS: clinical decision support system; DSM: diabetes self-management; HCP: health care provider; ICT: interactive computer teaching program; KAP: knowledge assessment program; UCDC: ubiquitous chronic disease care; WDS: WellDoc TM System

\section{Appendix 3. Baseline characteristics (I)}

\begin{tabular}{|c|c|c|c|c|c|c|}
\hline $\begin{array}{l}\text { Character- } \\
\text { istic } \\
\text { Study ID }\end{array}$ & $\begin{array}{l}\text { Interven- } \\
\text { tion(s) and } \\
\text { control(s) }\end{array}$ & Participating population & Setting & $\begin{array}{l}\text { Sex } \\
\text { [female\%] }\end{array}$ & $\begin{array}{l}\text { Age } \\
\text { [mean } \\
\text { years (SD) } \\
\text { or as stat- } \\
\text { ed] }\end{array}$ & $\begin{array}{l}\text { HbA1c } \\
\text { [mean \% } \\
(S D)]\end{array}$ \\
\hline $\begin{array}{l}\text { Christian } \\
2008\end{array}$ & $\begin{array}{l}\text { I: Computer ex- } \\
\text { pert system } \\
\text { C: Printed infor- } \\
\text { mation at base- } \\
\text { line then usual } \\
\text { care }\end{array}$ & $\begin{array}{l}\text { I: }>65 \% \text { family income at or below } \\
\$ 20650 \text { annually for a family of } 4 \\
\text { C: }>65 \% \text { family income at or below } \\
\$ 20650 \text { annually for a family of } 4\end{array}$ & $\begin{array}{l}\text { Clin- } \\
\text { ic-based }\end{array}$ & $\begin{array}{l}\text { I: } 65 \\
\text { C: } 68\end{array}$ & $\begin{array}{l}\text { I: } 53.0 \\
(11.3) \\
\text { C: } 53.4 \\
(10.7)\end{array}$ & $\begin{array}{l}\text { I: } 8.1(2) \\
\text { C: } 8.3(1.9)\end{array}$ \\
\hline $\begin{array}{l}\text { Glasgow } \\
1997\end{array}$ & $\begin{array}{l}\text { I: Computerised } \\
\text { touchscreen as- } \\
\text { sessment } \\
\text { C: Touch screen } \\
\text { assessment at } \\
\text { baseline then } \\
\text { usual care }\end{array}$ & $\begin{array}{l}\text { I: Unskilled worker } 45 \% \text {, semi-skilled } \\
\text { worker } 22 \% \text {, skilled worker/manager } \\
34 \% \\
\text { Education: High school or less: } 51 \% \text {, } \\
\text { some college } 27 \% \text {, College graduate } \\
22 \% \\
76 \% \text { type } 2 \text { DM, } 68 \% \text { on insulin } \\
\text { C: Unskilled worker } 52 \% \text {, semi-skilled } \\
\text { worker } 18 \% \text {, skilled worker/manager } \\
31 \%\end{array}$ & $\begin{array}{l}\text { Clin- } \\
\text { ic-based }\end{array}$ & $\begin{array}{l}\text { I: } 63 \\
\text { C: } 60\end{array}$ & $\begin{array}{l}\text { I: } 61.7 \\
(12.1) \\
\text { C: } 63.1 \\
(10.5)\end{array}$ & $\begin{array}{l}\text { I: } 7.9 \\
\text { C: } 7.9\end{array}$ \\
\hline
\end{tabular}


Education: High school or less: $41 \%$, some college $29 \%$, College graduate $30 \%$.

$81 \%$ type $2 \mathrm{DM}, 66 \%$ on insulin

\begin{tabular}{|c|c|c|c|c|c|c|}
\hline $\begin{array}{l}\text { Glasgow } \\
2003\end{array}$ & $\begin{array}{l}\text { I: Inter- } \\
\text { net-based peer } \\
\text { support } \\
\text { C: Access to ar- } \\
\text { ticles about di- } \\
\text { abetes }\end{array}$ & - & $\begin{array}{l}\text { Inter- } \\
\text { net-based }\end{array}$ & - & - & $\begin{array}{l}\text { I: } 7.5(1.7) \\
\text { C: } 7.4(1.6)\end{array}$ \\
\hline $\begin{array}{l}\text { Glasgow } \\
2005\end{array}$ & $\begin{array}{l}\text { I: Touchscreen } \\
\text { assessment } \\
\text { and self-man- } \\
\text { agement plan } \\
\text { C: Touch screen } \\
\text { assessment at } \\
\text { baseline then } \\
\text { usual care }\end{array}$ & $\begin{array}{l}\text { I: Income }<\$ 1000012.3 \%, 10-29.999 k \\
26.4 \%, 30-49.999 k 28 \%,>=50 k 33.3 \% \\
\text { Education: }<\text { High school } 13 \% \text {, High } \\
\text { school graduate } 27.1 \% \text {, College } 1-3 \\
\text { years } 32 \% \text {, College/grad school } 27.9 \% \\
5+\text { comorbidity } 6.1 \% \text {, no comorbid ill- } \\
\text { nesses } 2.0+/-0.11 \\
\text { C: Income }<\$ 1000010 \%, 10-29.999 k \\
33.9 \%, 30-49.999 k 23.9 \%,>=50 k 32.1 \% \\
\text { Education: }<\text { High school } 14.4 \% \text {, High } \\
\text { school graduate } 25.4 \%, \text { College } 1-3 \\
\text { years } 32.8 \% \text {, College/ grad school } \\
27.4 \% \\
5+\text { comorbidity } 6.5 \%, \text { no comorbid ill- } \\
\text { nesses } 2.2+/-0.11\end{array}$ & $\begin{array}{l}\text { Clin- } \\
\text { ic-based }\end{array}$ & $\begin{array}{l}\text { I: } 52 \\
\text { C: } 50\end{array}$ & $\begin{array}{l}\text { I: } 62(1.4) \\
\text { SE } \\
\text { C: } 64(1.3) \\
\text { SE }\end{array}$ & $\begin{array}{l}\text { I: } 7.3(1.3) \\
\text { C: } 7.3(1.2)\end{array}$ \\
\hline $\begin{array}{l}\text { Glasgow } \\
2006\end{array}$ & $\begin{array}{l}\text { I: Computer-tai- } \\
\text { lored self-man- } \\
\text { agement pro- } \\
\text { gram } \\
\text { C: Enhanced } \\
\text { usual care - } \\
\text { generic health } \\
\text { risk appraisal } \\
\text { then usual care }\end{array}$ & $\begin{array}{l}\text { I: Income }<\$ 100004.9 \%, 10-29.999 \mathrm{k} \\
25.0 \%, 30-49.999 \mathrm{k} 28.0 \%, 50-69.999 \mathrm{k} \\
20.1 \%, 70-89.999 \mathrm{k} 12.8 \%,>=90 \mathrm{k} 9.1 \\
\text { Education: Completed High School } \\
30.8 \% \text {, completed Technical School } \\
33.7 \% \text {, Completed college } 17.4 \% \text {, com- } \\
\text { pleted graduate degree } 18 \% \text {. } \\
24.2 \% \text { on insulin } \\
\text { C: Income }<\$ 100005.4 \%, 10-29.999 \mathrm{k} \\
19.5 \%, 30-49.999 \mathrm{k} 35.6 \%, 50-69.999 \mathrm{k} \\
18.8 \%, 70-89.999 \mathrm{k} 8.7 \%,>=90 \mathrm{k} 12.1 \\
\text { Education: Completed High School } \\
27.6 \% \text {, completed Technical School } \\
37.2 \% \text {, Completed college } 23.1 \%, \text { com- } \\
\text { pleted graduate degree } 12.2 \% \text {. } \\
\text { 19.2\% on insulin }\end{array}$ & $\begin{array}{l}\text { Clin- } \\
\text { ic-based }\end{array}$ & $\begin{array}{l}\text { I: } 50 \\
\text { C: } 50\end{array}$ & $\begin{array}{l}\text { I: } 62.0 \\
(11.7) \\
\text { C: } 61.0 \\
(11.0)\end{array}$ & $\begin{array}{l}\text { I: } 7.4(1.6) \\
\text { C: } 7.5(1.6)\end{array}$ \\
\hline $\begin{array}{l}\text { Glasgow } \\
2010\end{array}$ & $\begin{array}{l}\text { I: Computer as- } \\
\text { sisted self-man- } \\
\text { agement pro- } \\
\text { gram } \\
\text { C: Enhanced } \\
\text { usual care - } \\
\text { generic health }\end{array}$ & $\begin{array}{l}\text { I: Income less than } \$ 49,99945.7 \% \text {, } \\
\$ 50,000-\$ 89,99933.5 \%, \$ 90,000 \text { or } \\
\text { more } 20.6 \% \\
\text { Education: High school or less educa- } \\
\text { tion } 19.9 \% \\
\% \text { Low-moderate health literacy } 6.0 \%\end{array}$ & $\begin{array}{l}\text { Inter- } \\
\text { net-based }\end{array}$ & $\begin{array}{l}\text { I: } 45 \\
\text { C: } 52\end{array}$ & $\begin{array}{l}\text { I: } 58.7(9.3) \\
\text { C: } 58.7 \\
(9.1)\end{array}$ & $\begin{array}{l}\text { I: } 8.0(1.9) \\
\text { C: } 8.1(1.8)\end{array}$ \\
\hline
\end{tabular}


(Continued)

risk appraisal C: Income less than $\$ 49,99950.4 \%$,

then usual care $\$ 50,000-\$ 89,99936.6 \%, \$ 90,000$ or

more $13.0 \%$

Education: High school or less educa-

tion $13.0 \%$

$\%$ Low-moderate health literacy $7.6 \%$

\begin{tabular}{|c|c|c|c|c|c|c|}
\hline Leu 2005 & $\begin{array}{l}\text { I: Automated } \\
\text { wireless mes- } \\
\text { saging system } \\
\text { C: Presumed } \\
\text { usual care }\end{array}$ & $\begin{array}{l}50 \text { patients ( } 37 \text { with type } 2 \text { diabetes } \\
\text { and } 13 \text { with type } 1 \text { diabetes) enrolled in } \\
\text { the study: } \\
25 \text { in each group }=74 \% \text { T2DM, } 26 \% \\
\text { T1DM. }\end{array}$ & Pagers & - & $\begin{array}{l}\text { Average } \\
\text { age of } 51 \\
\text { years }\end{array}$ & $\begin{array}{l}\text { I: } 8.5 \\
\text { C: } 8.5\end{array}$ \\
\hline Lim 2011 & $\begin{array}{l}\text { I: Mobile phone } \\
\text { based blood } \\
\text { glucose man- } \\
\text { agement (u- } \\
\text { healthcare) } \\
\text { C: Baseline } \\
\text { face-to-face } \\
\text { education fol- } \\
\text { lowed by usual } \\
\text { care }\end{array}$ & 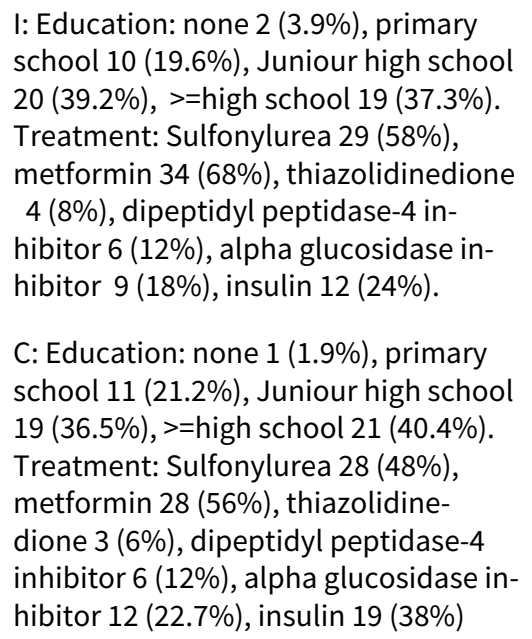 & $\begin{array}{l}\text { Mobile } \\
\text { phones }\end{array}$ & $\begin{array}{l}\text { I: } 54 \\
\text { C: } 62\end{array}$ & $\begin{array}{l}\text { I: } 67.2(4.1) \\
\text { C: } 68.1 \\
(5.5)\end{array}$ & $\begin{array}{l}\text { I: } 7.8(1.0) \\
\text { C: } 7.9(0.8)\end{array}$ \\
\hline Lo 1996 & $\begin{array}{l}\text { I: Computer-as- } \\
\text { sisted learning } \\
\text { C: Group dia- } \\
\text { betes educa- } \\
\text { tion sessions }\end{array}$ & $\begin{array}{l}\text { All participants had received individual } \\
\text { diabetes education when they were } \\
\text { newly diagnosed between } 2 \text { months } \\
\text { and } 10 \text { years prior to the study }\end{array}$ & $\begin{array}{l}\text { Clin- } \\
\text { ic-based }\end{array}$ & $\begin{array}{l}\text { I: } 75 \\
\text { C: } 50\end{array}$ & $\begin{array}{l}\text { I: } 61.6 \\
(11.6) \\
\text { C: } 63.4 \\
(8.9)\end{array}$ & $\begin{array}{l}\text { Non-stan- } \\
\text { dard units } \\
\text { (I: } 1280 \text { C: } \\
\text { 1088) }\end{array}$ \\
\hline Lorig 2010 & $\begin{array}{l}\text { I: Inter- } \\
\text { net-based Dia- } \\
\text { betes Self-Man- } \\
\text { agement Pro- } \\
\text { gram } \\
\text { C: Usual care }\end{array}$ & $\begin{array}{l}\text { I: Years of education } 15.7 \text { (2.93), com- } \\
\text { petent at using the Internet } \\
\text { C: Years of education } 15.8 \text { (3.06) years }\end{array}$ & $\begin{array}{l}\text { Inter- } \\
\text { net-based }\end{array}$ & $\begin{array}{l}\text { I: } 64 \\
\text { C: } 71\end{array}$ & $\begin{array}{l}\text { I: } 54.2(9.9) \\
\text { C: } 54.4 \\
(10.6)\end{array}$ & - \\
\hline $\begin{array}{l}\text { Quinn } \\
2008\end{array}$ & $\begin{array}{l}\text { I: Mobile } \\
\text { phone-based } \\
\text { blood glucose } \\
\text { management } \\
\text { (WellDoc) } \\
\text { C: provided } \\
\text { blood glucose } \\
\text { meters and en- } \\
\text { couraged par- } \\
\text { ticipants to fax } \\
\text { their results to } \\
\text { their healthcare } \\
\text { providers every }\end{array}$ & $\begin{array}{l}\text { Prior to study enrolment, most partic- } \\
\text { ipants ( } n=12 \text { ) owned and used a cell } \\
\text { phone daily, one reported owning a } \\
\text { cell phone for emergency use only, and } \\
\text { another used a smart phone (personal } \\
\text { digital assistant type). } \\
\text { I: Oral hypoglycaemic agents alone } \\
3 / 13 \text {, insulin alone } 4 / 13 \text {, injectable } \\
\text { non-insulin } 6 / 13 \\
\text { Hypertension } 8 \text {, hyperlipidaemia } 8 \text {, } \\
\text { coronary artery diseases } 1 \text {, microvas- } \\
\text { cular complications } 4\end{array}$ & $\begin{array}{l}\text { Mobile } \\
\text { phones }\end{array}$ & $\begin{array}{l}\text { I: } 69 \\
\text { C: } 62\end{array}$ & $\begin{array}{l}\text { I: } 8 \text { aged } \\
20-54 \\
5 \text { aged } \\
55-64 \\
\text { C: } 6 \text { aged } \\
20-54 \\
7 \text { aged } \\
55-64\end{array}$ & $\begin{array}{l}\text { I: } 9.5 \\
\text { C: } 9.1\end{array}$ \\
\hline
\end{tabular}


(Continued)

two weeks until blood glucose was stabilised
C: Oral hypoglycaemic agents alone 7 , insulin alone 4, insulin and oral hypoglycaemic 0 , injectable non-insulins 1 , Hypertension $8 / 13$, hyperlipidaemia $6 / 13$, coronary artery disease $0 / 13$, microvascular complications $4 / 13$

\begin{tabular}{|c|c|c|c|c|c|c|}
\hline $\begin{array}{l}\text { Quinn } \\
2011\end{array}$ & $\begin{array}{l}\text { I: Mobile } \\
\text { phone-based } \\
\text { diabetes inter- } \\
\text { vention (coach- } \\
\text { only group) } \\
\text { C: Usual care } \\
\text { (but patients } \\
\text { received a } \\
\text { blood glucose } \\
\text { meter and sup- } \\
\text { plies for } 1 \text { year) }\end{array}$ & $\begin{array}{l}\text { I: Smoking status: Current smok- } \\
\text { ers } 26.1 \% \text {, former smokers } 4.3 \% \text {, non- } \\
\text { smokers } 69.6 \% \\
\text { Education: High school/trade school } \\
\text { or less } 30.4 \% \text {, some College or asso- } \\
\text { ciates } 43.5 \% \text {, Bachelors degree or } \\
\text { higher } 26.1 \% \\
\text { Depression (PHQ-9) score: } 5.2 \text { (4.8) } \\
\text { BMI } 36.9 \text { (7.5) } \\
\text { Comorbidities: Hypertension } 78.3 \% \text {, } \\
\text { hypercholestaerolemia } 47.8 \% \text {, coro- } \\
\text { nary artery disease } 8.7 \% \text {, microvascu- } \\
\text { lar complications, any } 4.3 \% \\
\text { C: Smoking status: Current smok- } \\
\text { ers } 19.6 \%, \text { former smokers } 1.8 \%, \text { non- } \\
\text { smokers } 78.6 \% \text {, } \\
\text { Education: High school/trade school } \\
\text { or less } 25 \%, \text { some College or asso- } \\
\text { ciates } 35.7 \%, \text { Bachelors degree or } \\
\text { higher } 39.3 \% \\
\text { Depression (PHQ-9) score: } 4.7 \text { (5.6) } \\
\text { BMI } 34.3(6.3 \text { ) } \\
\text { Comorbidities: Hypertension } 51.8 \% \text {, } \\
\text { hypercholestaerolemia } 60.7 \% \text {, coro- } \\
\text { nary artery disease } 8.9 \% \text {, microvascu- } \\
\text { lar complications, any } 14.3 \%\end{array}$ & $\begin{array}{l}\text { Mobile } \\
\text { phones }\end{array}$ & $\begin{array}{l}\text { I: } 48 \\
\text { C: } 50\end{array}$ & $\begin{array}{l}\text { I: } 52.8(8.0) \\
\text { C: } 53.2 \\
(8.4)\end{array}$ & $\begin{array}{l}\text { I: } 9.3(1.8) \\
\text { C: } 9.2(1.7)\end{array}$ \\
\hline Smith 2000 & $\begin{array}{l}\text { I: Firstclass } \\
\text { software - Inter- } \\
\text { net-based self- } \\
\text { management } \\
\text { program } \\
\text { C: Hard copies } \\
\text { of materials }\end{array}$ & $\begin{array}{l}60 \% \text { participants employed } \\
80 \% \text { type } 2 \text { DM }\end{array}$ & $\begin{array}{l}\text { Inter- } \\
\text { net-based }\end{array}$ & All 100 & $\begin{array}{l}\text { Mean age } \\
46.7\end{array}$ & - \\
\hline Wise 1986 & $\begin{array}{l}\text { I: Interactive } \\
\text { computer } \\
\text { teaching and } \\
\text { knowledge as- } \\
\text { sessment } \\
\text { C: Presumed } \\
\text { usual care }\end{array}$ & $\begin{array}{l}\text { All patients had previously received } \\
\text { some instruction, mainly by a diabetes } \\
\text { type-specific teaching text together } \\
\text { with individual counselling at various } \\
\text { stages in their diabetic history }\end{array}$ & $\begin{array}{l}\text { Clin- } \\
\text { ic-based }\end{array}$ & - & 55 (21) SE & $\begin{array}{l}\text { I: } 8.7(0.7) \\
\text { C: } 8.7\end{array}$ \\
\hline Yoo 2009 & $\begin{array}{l}\text { I: Mobile } \\
\text { phone-based } \\
\text { diabetes self- } \\
\text { management } \\
\text { (UCDC) } \\
\text { C: Usual care }\end{array}$ & Co-morbidity: $100 \%$ had hypertension & $\begin{array}{l}\text { Mobile } \\
\text { phones }\end{array}$ & $\begin{array}{l}\text { I: } 47 \\
\text { C: } 35\end{array}$ & $\begin{array}{l}\text { I: } 57.0(9.1) \\
\text { C: } 59.4 \\
(8.4)\end{array}$ & $\begin{array}{l}\text { I: } 7.6(0.9) \\
\text { C: } 7.4(0.9)\end{array}$ \\
\hline
\end{tabular}


Zhou 2003

I: Diabetes diet advisor V1.0

Co-morbidity: $100 \%$ had hypertension

Inter-

I: 61

net-based

C: 56

I: $62.4(8.3)$

I: $8.7(1.5)$

C: Fixed carbo-

C: 59.8

(11.0)

hydrate con-

tent

\section{Footnotes}

"-" denotes not reported

BMI: body mass index; C: control; HbA1c: DM: diabetes mellitus; glycated haemoglobin A1c; I: intervention; SD: standard deviation; SE: standard error; UCDC: ubiquitous chronic disease care 


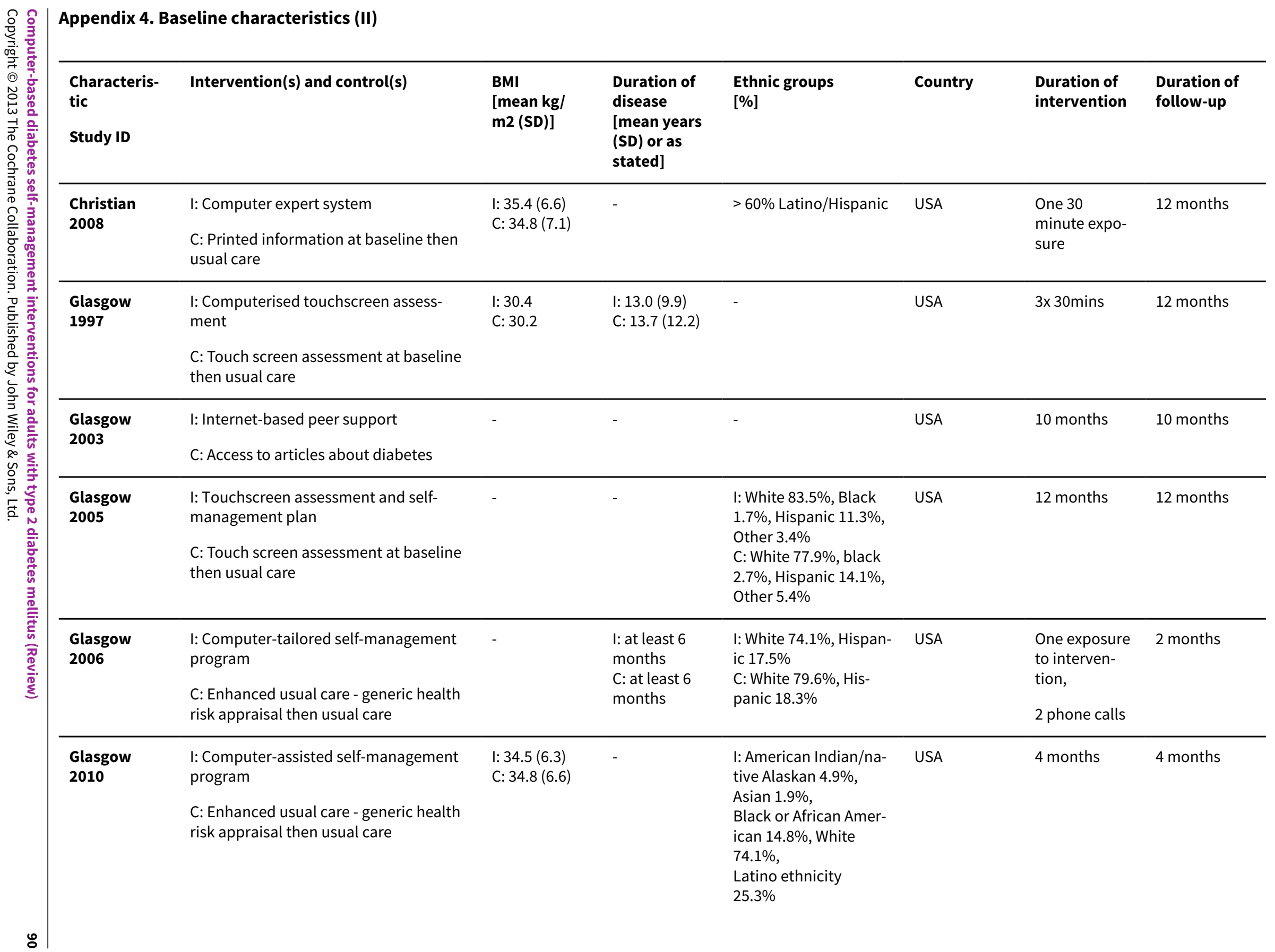




\begin{tabular}{|c|c|c|c|c|c|c|c|c|}
\hline 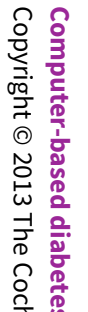 & (Continued) & & & & $\begin{array}{l}\text { C: American Indi- } \\
\text { an/native Alaskan } \\
11.1 \% \text {, Asian } 1.6 \% \text {, } \\
\text { Black or African Amer- } \\
\text { ican } 12.7 \% \text {, White } \\
70.6 \% \text {, } \\
\text { Latino ethnicity } 16.8 \%\end{array}$ & & & \\
\hline 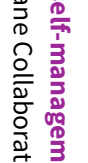 & Leu 2005 & $\begin{array}{l}\text { I: Automated wireless messaging system } \\
\text { C: Presumed usual care }\end{array}$ & - & - & Predominently White & USA & $3-6$ months & $\begin{array}{l}\text { I: on average } \\
153 \text { days } \\
\text { C: on average } \\
138 \text { days }\end{array}$ \\
\hline 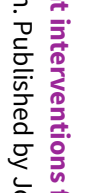 & Lim 2011 & $\begin{array}{l}\text { I: Mobile phone-based blood glucose } \\
\text { management (u-healthcare) } \\
\text { C: Baseline face-to-face education fol- } \\
\text { lowed by usual care }\end{array}$ & $\begin{array}{l}\text { I: } 24.7(2.4) \\
\text { C: } 25.5(3.3)\end{array}$ & $\begin{array}{l}\text { I: } 14.1(10.1) \\
\text { C: } 15.8(10.7)\end{array}$ & - & South Korea & 6 months & 6 months \\
\hline 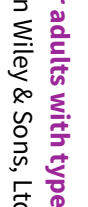 & Lo 1996 & $\begin{array}{l}\text { I: Computer-assisted learning } \\
\text { C: Group diabetes education sessions }\end{array}$ & - & - & - & Australia & $\begin{array}{l}\text { I: } 3-6 \text { sessions, } \\
1 \text { hour each } \\
\text { C: } 4 \text { weekly } \\
\text { sessions } 2.5-3 \\
\text { hours }\end{array}$ & 3 months \\
\hline 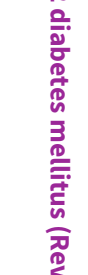 & Lorig 2010 & $\begin{array}{l}\text { I: Internet-based Diabetes Self-Manage- } \\
\text { ment Program } \\
\text { C: Usual care }\end{array}$ & - & - & $\begin{array}{l}\text { I: } 78 \% \text { non-Hispanic } \\
\text { White } \\
\text { C: } 71.1 \% \text { non-Hispan- } \\
\text { ic White }\end{array}$ & USA & $6-18$ months & $\begin{array}{l}\text { HbAlc mea- } \\
\text { sured at } 6 \\
\text { months, } \\
\text { other out- } \\
\text { comes } 18 \\
\text { months }\end{array}$ \\
\hline & Quinn 2008 & $\begin{array}{l}\text { I: Mobile phone-based blood glucose } \\
\text { management (WellDoc) } \\
\text { C: provided blood glucose meters and } \\
\text { encouraged participants to fax their re- } \\
\text { sults to their healthcare providers every } \\
\text { two weeks until blood glucose was sta- } \\
\text { bilised }\end{array}$ & - & $\begin{array}{l}\text { I: } 7.6 \\
\text { C: } 11\end{array}$ & $\begin{array}{l}\text { I: } 10 / 13 \text { African } 77 \% \\
3 / 13 \text { non-Hispanic } \\
\text { White } 23 \% \\
\text { C: } 6 / 13 \text { African } 46 \% \\
7 / 13 \text { non-Hispanic } \\
\text { White } 54 \%\end{array}$ & USA & 3 months & 3 months \\
\hline ڤ & Quinn 2011 & $\begin{array}{l}\text { I: Mobile phone-based diabetes inter- } \\
\text { vention (coach-only group) }\end{array}$ & $\begin{array}{l}\text { I: } 36.9(7.5) \\
\text { C: } 34.3(6.3)\end{array}$ & $\begin{array}{l}\text { I: } 7.7(5.6) \\
\text { C: } 9.0(7.0)\end{array}$ & $\begin{array}{l}\text { I: Black (non-Hispanic) } \\
43.5 \% \\
\text { White (non-Hispan- } \\
\text { ic) } 52.2 \% \text {, Other } 4.3 \%\end{array}$ & USA & 12 months & 12 months \\
\hline
\end{tabular}




\begin{tabular}{|c|c|c|c|c|c|c|c|c|}
\hline \multirow{2}{*}{\multicolumn{2}{|c|}{ 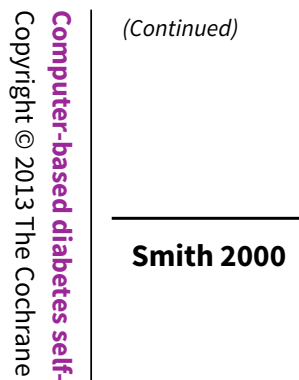 }} & \multicolumn{3}{|l|}{$\begin{array}{l}\text { C: Usual care (but patients received a } \\
\text { blood glucose meter and supplies for } 1 \\
\text { year) }\end{array}$} & \multicolumn{4}{|c|}{$\begin{array}{l}\text { C: Black (non-Hispan- } \\
\text { ic) } 48.2 \% \\
\text { White (non-Hispanic) } \\
46.4 \% \text {, Other } 5.4 \%\end{array}$} \\
\hline & & $\begin{array}{l}\text { I: Firstclass software - Internet-based } \\
\text { self-management program } \\
\text { C: Hard copies of materials }\end{array}$ & - & - & - & USA & 5 months & 5 months \\
\hline 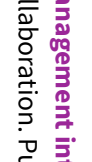 & Wise 1986 & $\begin{array}{l}\text { I: Interactive computer teaching and } \\
\text { knowledge assessment } \\
\text { C: Presumed usual care }\end{array}$ & - & $\begin{array}{l}\text { I: } 8 \text { (5) SE } \\
\text { C: } 7 \text { (4) SE }\end{array}$ & - & UK & $4-6$ months & 4-6 months \\
\hline 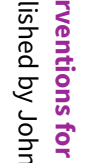 & Yoo 2009 & $\begin{array}{l}\text { I: Mobile phone-based diabetes self- } \\
\text { management (UCDC) } \\
\text { C: Usual care }\end{array}$ & $\begin{array}{l}\text { I: } 25.6(3.5) \\
\text { C: } 25.5(3.3)\end{array}$ & $\begin{array}{l}\text { I: } 6.0(5.4) \\
\text { C: } 7.2(6.0)\end{array}$ & - & South Korea & 12 weeks & 12 weeks \\
\hline 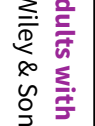 & Zhou 2003 & $\begin{array}{l}\text { I: Diabetes diet advisor V1.0 } \\
\text { C: Fixed carbohydrate content }\end{array}$ & $\begin{array}{l}\text { I: } 24.0(3.1) \\
\text { C: } 24.5(2.8)\end{array}$ & - & - & China & 8 weeks & 8 weeks \\
\hline 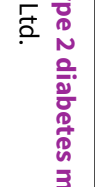 & $\begin{array}{l}\text { Footnotes } \\
\text { "-" denotes n } \\
\text { C: control; I: i }\end{array}$ & $\begin{array}{l}\text { eported } \\
\text { rvention; SD: standard deviation; SE: st }\end{array}$ & ard error; UCD & biquitous ch & disease care & & & \\
\hline
\end{tabular}




\section{Appendix 5. Matrix of study endpoints}

\begin{tabular}{|c|c|c|c|}
\hline $\begin{array}{l}\text { Characteristic } \\
\text { Study ID }\end{array}$ & $\begin{array}{l}\text { Primarya end- } \\
\text { point(s) }\end{array}$ & Secondaryb endpoints & Otherc endpoints \\
\hline Christian 2008 & Loss of body weight & $\begin{array}{l}\text { Change in } \mathrm{HbAlc} \\
\text { Energy intake } \\
\text { Lipids } \\
\text { Physical activity }\end{array}$ & $\begin{array}{l}\text { Blood pressure } \\
\text { Waist circumfer- } \\
\text { ence }\end{array}$ \\
\hline Glasgow 1997 & - & $\begin{array}{l}\% \text { Calories from fat } \\
\% \text { Calories from saturated fat } \\
\text { BMI } \\
\text { Food habit questionnaire } \\
\text { HbA1c } \\
\text { Lipids }\end{array}$ & $\begin{array}{l}\text { Economic data } \\
\text { Dietary behaviour }\end{array}$ \\
\hline Glasgow 2003 & $\begin{array}{l}\text { Changes in dietary } \\
\text { behaviours (fat and } \\
\text { fruit/vegetable in- } \\
\text { take) }\end{array}$ & $\begin{array}{l}\text { Average minutes of physical activity per day } \\
\text { Cases of incorrect medical information being posted } \\
\text { Centre for Epidemiologic Depression Scale } \\
\text { Diabetes support scale } \\
\text { Guidelines met } \\
\text { HbA1c } \\
\text { Logons per participant per month } \\
\text { Total cholesterol to HDL-cholesterol ratio }\end{array}$ & \\
\hline Glasgow 2005 & $\begin{array}{l}\text { Number of recom- } \\
\text { mended laboratory } \\
\text { screenings and rec- } \\
\text { ommended } \\
\text { patient-centred } \\
\text { care activities com- } \\
\text { pleted }\end{array}$ & $\begin{array}{l}\text { Baseline to } 12 \text {-month change in perceived competence } \\
\text { Baseline to } 12 \text {-month change in provider autonomy support } \\
\text { HbA1C } \\
\text { Health-related quality of life } \\
\text { PHQ-9 score of } 10 \text { or higher } \\
\text { Total cholesterol to HDL-cholesterol ratio }\end{array}$ & \\
\hline Glasgow 2006 & - & $\begin{array}{l}\text { Diabetes distress scale } \\
\text { HbA1c } \\
\text { Lipids } \\
\text { Fruit and vegetable screener score } \\
\text { Estimated daily fat intake }\end{array}$ & \\
\hline
\end{tabular}


PHQ-9 score

Weight

\begin{tabular}{|c|c|c|}
\hline Glasgow 2010 & $\begin{array}{l}\text { Behaviour changes } \\
\text { in healthy eating, } \\
\text { physical activi- } \\
\text { ty and mediation } \\
\text { changes }\end{array}$ & $\begin{array}{l}\text { Blood pressure } \\
\text { BMI } \\
\text { Eating habits } \\
\text { Fat intake } \\
\text { HbAlc } \\
\text { Medication adherence } \\
\text { Physical activity } \\
\text { Total cholesterol to HDL-cholesterol ratio }\end{array}$ \\
\hline Leu 2005 & $\mathrm{HbA1c}$ & Blood pressure \\
\hline Lim 2011 & $\begin{array}{l}\text { Proportion of pa- } \\
\text { tients that achieved } \\
\text { HbA1c }<7.0 \% \text { with- } \\
\text { out hypoglycaemia }\end{array}$ & $\begin{array}{l}\text { BMI } \\
\text { Fasting glucose } \\
\text { Frequency of self-monitored blood glucose } \\
\text { HbA1c } \\
\text { Lipids } \\
\text { Postprandial glucose } \\
\text { Weight }\end{array}$ \\
\hline Lo 1996 & - & $\begin{array}{l}\text { HbA1c } \\
\text { Knowledge }\end{array}$ \\
\hline
\end{tabular}

Lorig 2010

Change in $\mathrm{HbAlc}$

Health distress scale change

Activity limitation scale change

Self efficacy scale change

Change in aerobic exercise per week

PHQ9 score

PAM patient activation scale

\begin{tabular}{ll}
\hline Quinn 2008 & Adherence (diabetes self-care score) \\
& Being confident about diabetes control \\
& Diet (diabetes self-care score) \\
& Exercise (diabetes self-care score) \\
& HbAlc \\
& Improved knowledge of food choices \\
& Medication errors identified
\end{tabular}


Medication intensified

New diagnosis of depression

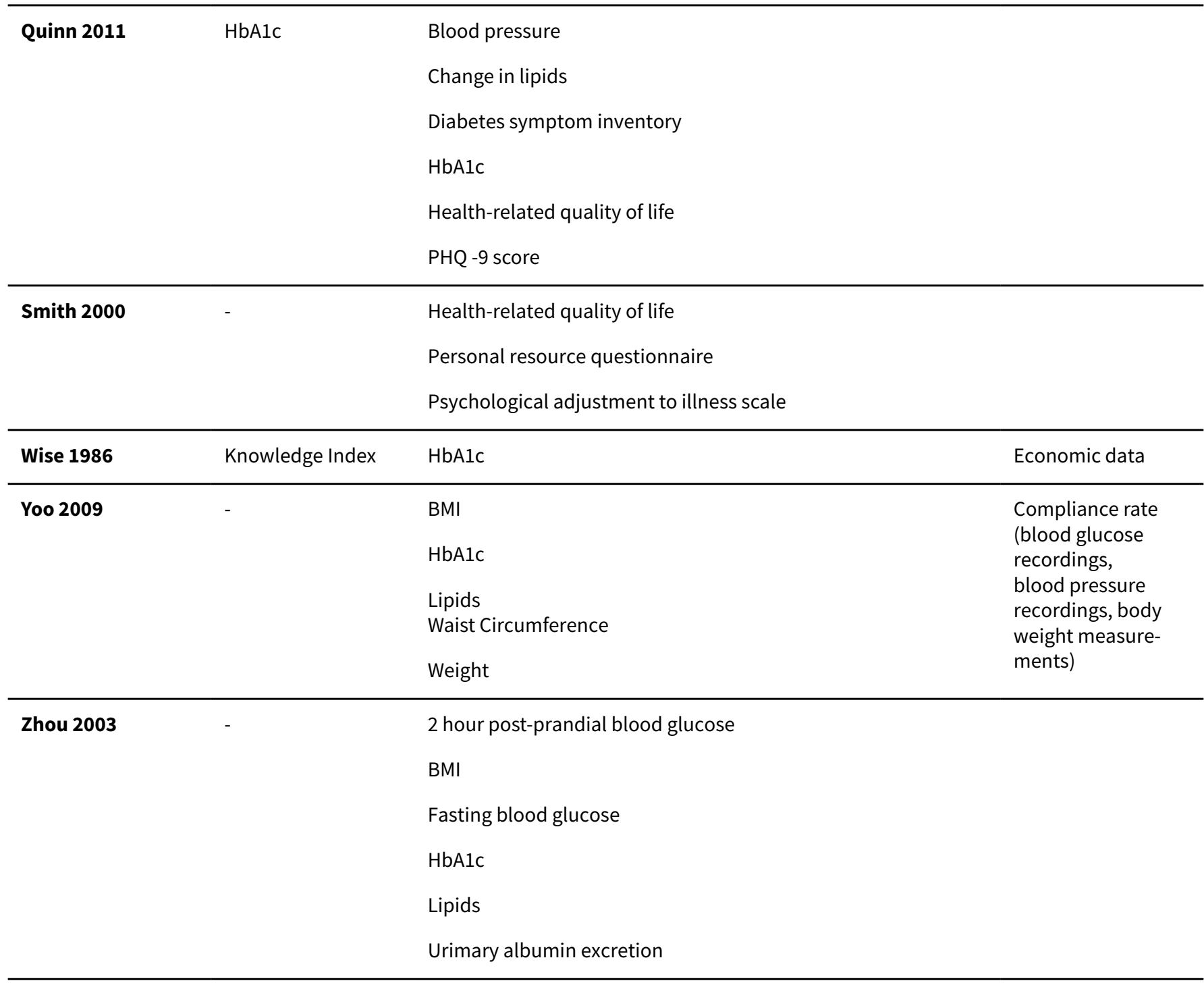

\section{Footnotes}

"-" denotes not reported

a,bAs stated in the publication

cNot stated as primary or secondary endpoint(s) in the publication

BMI: body mass index; C: control; HbA1c: glycosylated haemoglobin A1c; I: intervention; HDL: high-density lipoprotein; PAM: patient activation measure; PHQ-9: patient health questionnaire

\section{Appendix 6. Original study data}

$\begin{array}{ll}\text { Characteristic } & \begin{array}{l}\text { Primarya end- } \\ \text { point(s) }\end{array}\end{array}$

Otherc endpoints 


\section{Christian 2008}

Intervention: Change: $-0.08 \mathrm{~kg}$ (4.95) Lost $5 \%$ body weight or more in 12-month period: $30(21 \%)$

Control: Change: $0.63 \mathrm{~kg}$ (4.81) Lost $5 \%$ body weight or more in 12-month period: $14(11 \%)$
Intervention:

Physical activity: baseline physical activity in MET-min 478.2

[1098.1], change MET-min/wk 354 [574] $95 \mathrm{Cl} 257.5$ to 451.4

Energy intake: baseline Caloric intake per week 12787.3

[3187.2], change kcal/wk -947 [1936] 95Cl -1271.0 to -623.4

Lipids: TC: baseline: 4.94 (1.20), change: $-0.41(1.16)(95 \% \mathrm{Cl}$ :

-0.60 to- 0.22 )

HDL: baseline: 1.09 (0.33), change: $0.01(0.44)(95 \% \mathrm{Cl}:-0.08$ to 0.06)

LDL: baseline: 2.59 (0.83), change: -0.38 (1.00) $(95 \% \mathrm{Cl}:-0.54$ to -0.21 )

Trigs: baseline: 2.01 (1.17), change: -0.15 (1.09) $(95 \% \mathrm{Cl}:-0.33$ to 0.03)

HbA1c: change: $-0.141(1.76)$

Control:

Physical activity: baseline physical activity in MET-min 442.0

[709.9], change in physical activity MET-min/week 51[443]

$95 \mathrm{Cl}-25.72$ to 127.72

Energy intake: baseline Caloric intake per week 12211.5

[3495.1], change in caloric intake -507 [1963] 95Cl-847.7 to

$-166.3$

Lipids: TC: baseline: 4.90 (1.42), change: -0.10 (1.17) (95\% Cl:

-0.30 to 0.10 )

HDL: baseline: 1.15 (0.48), change: 0.04 (0.30) (95\% Cl: -0.01 to 0.09)

LDL: baseline: 2.74 (1.00), change: $-0.10(1.00)(95 \% \mathrm{Cl}:-0.27$ to $0.07)$

Trigs: baseline: 2.09 (2.90), change: -0.11 (1.07) (95\% Cl: -0.29 to 0.08)

HbA1c: change -0.46 (1.63)
Intervention:

BP: base systolic

131.80 [17.02], dias-

tolic 76.56 [10.53],

change -2.55 [20.37]

$95 \mathrm{Cl}-5.942$ to

0.841

change -2.60

[13.79] $95 \mathrm{Cl}-4.896$

to 0.304

Waist circumfer-

ence: base WC

118.1 [14.95],

change -1.764

[7.045] 95Cl-2.941

to 0.586

Control:

BP: base systolic

132.26 [17.43], diastolic 77.83 [9.58], change in systolic:

$-4.66[20.81] 95 \mathrm{Cl}$

-8.243 to -1.077 , change in diastolic

-2.54 [11.63] 95C

-4.640 to -0.637

Waist circumfer-

ence: base WC

116.6 [15.23],

change -0.543

[6.498] 95Cl - 1.670

to 0.589

Overall MANCO-

VA for dietary behaviour: F statistic $(3,140)=3.16$, P val ue $=0.008$

Economic data:

cost totaled $\$ 14755$

or $\$ 137$ per participant. \$7478 for labour,

$\$ 4627$ for materials, postage and phone $\$ 2650$ for computer hardware and software.

Overall \$62 per reduction of each \%age of in diet fat $\$ 105$ per percent reduction in sat fat and $\$ 8$ per $\mathrm{mg} / \mathrm{dl}$ reduction in serum cholesterol 
$\%$ Cal from fat: baseline $32.9 ; 12$ months $32.0 \mathrm{P}=0.023$, 3month data $31.9, \mathrm{P}=0.008, \mathrm{n}=154$

$\%$ Cal from sat fat: baseline 10.8, 3-month data $10.7, P=0.007$, $\mathrm{n}=152,12$ months $10.7 \mathrm{P}=0.003$
Total cost per patient:

if 100 patients seen per year: $\$ 139$ if 500 patients seen per year: $\$ 117$ if 1000 patients seen per year: $\$ 115$ Cost per $1 \%$ recent reduction in fat intake:

if 100 patients seen per year: $\$ 63$ if 500 patients seen per year: $\$ 53$ if 1000 patients seen per year: $\$ 52$ Cost per unit reduction in cholesterol:

if 100 patients seen per year: $\$ 8.40$ if 500 patients seen per year: $\$ 7.11$ if 1000 patients seen per year: $\$ 6.95$

$100 \%$ participation in on-line dietary assessment.

\section{behaviours (fat and} fruit/vegetable intake)

Intervention:

Kristal Fat and Fiber behaviour scale (low is good): baseline: $2.19(0.5)$, 10 months 1.96 (0.38), group differences (no intervention-intervention) 0.04

Estimated grams of daily fat: baseline: 44.0 (31.9), 10 months 27.9 (14.3), group differences (no intervention- intervention) 1.85 Control:

Kristal Fat and Fiber behaviour scale (low is good): baseline: 2.22 ( 0.41),10 months 2.00 (0.38), group differences (no interventionintervention) 0.04, MANCOVA univariate $\mathrm{P}$ level 0.399 .
Intervention:

HbA1c: baseline: 7.54 (1.68), 10 months 7.42 (1.10), group differences (no intervention- intervention) 0.28

Total cholesterol: HDL cholesterol ratio: baseline: 5.43 (1.59), 10 months 5.02 (1.16), group differences (no intervention- intervention) 0.11

Average minutes of physical activity per day: Peer support: baseline: 29.4 (22.3), 10 months 30.5 (22.8), group differences (no intervention- intervention) 1.96, MANCOVA univariate $P$ level 0.512 .

Guidelines met (\%): Peer support: baseline: 64.82 (20.96), 10 months 79.43 (14.71),

group differences (no intervention- intervention) -0.49, MANCOVA univariate $P$ level 0.798 .

Diabetes support scale: Peer support: baseline: 4.05 (1.28), 10 months 5.22 (1.11), group differences (no intervention- intervention) -0.51, MANCOVA univariate $P$ level 0.001 - i.e. significant at the 0.05 level. Centre for Epidemiologic Depression Scale: Peer support: baseline: 18.1 (10.51), 10 months 12.59 (9.13),

group differences (no intervention- intervention) 1.47, MANCOVA univariate $P$ level 0.219

No cases of incorrect medical information being posted Logons per participant per month: months 1-3: 18.7, months

7-10: 6.7

Control:

HbA1c: baseline: 7.35 (1.56), 10 months 7.68 (1.10), group differences (no intervention- intervention) 0.28, MANCOVA univariate $P$ level 0.051 - i.e. significant at 0.05 level TC: HDL ratio: baseline 5.44 (1.79), 10-month adjusted mean $5.13(1.16)$ Average minutes of physical activity per day: baseline: $30.7+$ (24.1), 10 months $32.5+/-(22.8)$ 
Estimated grams of daily fat: baseline: 41.3 (26.4), 10 months $29.8(14.3)$ group differences (no intervention- intervention) 1.96, MANCOVA univariate $P$ level 0.512 .

Guidelines met (\%): baseline: 65.19 (19.51), 10 months 78.94 (14.71).

group differences (no intervention- intervention) -0.49, MANCOVA/ univariate P level 0.798 .

Diabetes support scale: baseline: 4.23 (1.23), 10 months 4.71

(1.12), group differences (no intervention- intervention) -0.51, MANCOVA univariate $P$ level 0.001 - i.e. significant at the 0.05 level. Centre for Epidemiologic Depression Scale: baseline: 17.8 (10.08), 10 months 14.06 (9.12), group differences (no intervention- intervention) 1.47, MANCOVA/ univariate P level 0.219 .

Logons per participant per month: months 1-3: 9.4, months 7-10: 3.6

\section{Glasgow 2005}

\author{
Number of recom- \\ mended laborato- \\ ry screenings and \\ recommended pa- \\ tient-centred care \\ activities complet- \\ ed \\ from the Nation- \\ al Committee on \\ Quality Assurance/ \\ American Dia- \\ betes Association \\ Provider Recogni- \\ tion Program (PRP) \\ Lab procedures \\ completed: \\ I: baseline \\ 3.92(0.99) 12 \\ months 4.29 (0.86) \\ C: baseline \\ 3.88(1.06) 12 \\ months 4.01 (1.06) \\ Patient centred ac- \\ tivities: \\ I: baseline 3.04 \\ (0.99) 12 months \\ $3.74(0.57)$ \\ C: baseline 2.93 \\ (1.03) 12 months \\ $3.31(0.86)$
}

\section{Intervention:}

HRQOL: PAID-2 base: $30.28+/-4.22,6$ months $29.72+/-4.90,12$ months $29.7+/-4.9$

HbA1c: base: $7.33+$ +- 1.34 MEAN+/- SE, 12 months $7.14+/-1.38$, TC: HDL ratio base: $4.32+/-1.19,12$ months: $4.17+/$ -

1.18, MEAN +/- SE

PHQ-9 score of 10 or higher: Baseline: 19.2\%, 6 months: (from 2053) $17.4 \%$ = unadjusted percentage, $15.0 \%$ = adjusted percentage, $\mathrm{P}=0.747$ from ANCOVA with control,12 months: unadjusted $12.2 \%, 12$-month adjusted $12.3 \%$

Baseline to 12-month change in provider autonomy support : $6.05+/-0.05=$ mean $+/-$ SE

Baseline to 12-month change in perceived competence: 5.90 $+/-0.06=$ mean $+/-\mathrm{SE}$

Control:

HRQOL: PAID-2 baseline: 28.54 +/- 5.02 (SD), 6 months: 26.78 +/$4.35,12$ months $26.8+/-4.4$

HbA1c: baseline: 7.30 +/- 1.22 ?Mean +/- SE, 12 months $7.13+/$ 1.06

TC: HDL ratio base: $4.38+/-1.16,4.14+/-1.16$ MEAN +/- SE PHQ-9 score of 10 or higher: Baseline 16.1\%, 6 months: (from 2053) $11.4 \%=$ unadjusted percentage, $13.4 \%=$ adjusted percentage,

12 months: $13.6 \%$ = unadjusted percentage, $13.9 \%=$ adjusted percentage (from 1683)

Baseline to 12-month change in provider autonomy support: $5.89+/-0.05$ ?mean +/- SE

Baseline to 12-month change in perceived competence: 5.75 +/- 0.07 ?mean +/- SE

\section{Glasgow 2006}

Intervention:

Diabetes distress scale: baseline 40.1 (17.5), visit 233.6 (14.2)

HbA1c: Baseline 7.4 (1.6), final 7.3(1.5)

TC/HDL ratio: baseline 3.9 (1.2), 2 months 3.8 (1.0)

Total cholesterol mmol/L: baseline 4.79 (1.17), 2 months 4.74

(1.00)

HDL cholesterol mmol/L: baseline 1.27 (0.42), 2 months 1.30

(0.39)

Fruit and Vegetable screener score: Baseline 5.5(3.8), final 5.7

(4.8)

Estimated daily fat intake: baseline 27.6 (17.9), final 22.4 (15.2) PHQ-9 baseline 5.7 (4.9): final 5.5 (5.0) 
Weight: baseline 94.3 (24.6), final 93.6 (23.6)

Control:

Diabetes distress scale: baseline 41.5 (18.9), visit 236.2 (17.0)

HbA1c: Baseline 7.5(1.6), final 7.5(1.8)

TC/HDL ratio: baseline 3.9 (1.0), 2 months 3.8 (1.1)

Total cholesterol mmol/L: baseline 4.79 (1.09), 2 months 4.76

(0.93)

HDL cholesterol mmol/L: baseline 1.29 (0.36), 2 months 1.32

(0.38)

Fruit and Vegetable screener score: Baseline 5.1 (3.0), final 5.0

(3.4)

Estimated daily fat intake: baseline 32.4 (20.9), final 28.5 (17.8),

PHQ-9: baseline 5.4 (5.1), final 5.5 (5.3)

Weight: baseline 94.0 (24.5), final 94.0 (24.5)

\section{Glasgow 2010}

Behaviour changes in healthy eating, physical activity and mediation changes
Intervention:

HbA1c: ITTA (Intention to treat analysis - used in meta-analysis), Baseline: 8.01 (1.85), 4 months: 7.84 (1.67)

Complete cases (used in meta-analysis), Baseline: 7.86 (1.59), 4 months: 7.76 (1.50)

BMI: ITTA (used in meta-analysis), Baseline: 34.47 (6.28), 4 months: 34.39 (6.27), Complete cases, Baseline: 34.58 (6.46), 4 months: 34.54 (6.41)

BP: Mean arterial pressure ( $\mathrm{mm} \mathrm{Hg}$ ), ITTA (used in meta-analysis), Baseline: 95.42 (10.40), 4 months: 94.27 (10.20)

Complete cases, Baseline: 94.48 (9.69), 4 months: 93.83 (10.27) Lipids:

Total cholesterol: HDL ratio: ITTA (used in analysis), Baseline: 4.00 (1.25), 4 months: 3.84 (1.16), Complete cases

Baseline: 3.87 (1.04), 4 months: 3.74 (0.98)

Diet: Eating habits - "Starting the conversation" scale -: ITTA (used in analysis), Baseline: 2.19 (0.33), 4 months: 2.34 (0.31), Complete cases, Baseline: 2.17 (0.34), 4 months: 2.32 (0.3) Fat intake - National Cancer Institute \% energy from fat screen: ITTA (used in analysis), Baseline: 35.03 (5.71), 4 months: 33.48 (5.77),

Complete cases, Baseline: 35.23 (5.56), 4 months: 33.83 (5.54) Physical Activity: Physical activity (cals per week) - CHAMPS questionnaire: ITTA (used in analysis), Baseline: 4294 (3054), 4 months: 4146 (3578), Complete cases, Baseline: 4483 (3035), 4 months: 4262 (3433)

Adherence: Medication adherence - Hill Bone Compliance scale: ITTA (used in analysis), Baseline: 3.77 (0.34), 4 months: 3.83 (0.33),

Complete cases, Baseline: 3.80 (0.26), 4 months: $3.83(0.32)$

Control:

HbA1c: ITTA (Intention to treat analysis - used in analysis), Baseline: 8.06 (1.76), 4 months: 8.00 (1.58), Complete cases Baseline: 7.82 (1.54), 4 months: 7.78 (1.38)

BMI: ITTA (used in analysis), Baseline: 34.77 (6.55), 4 months: 34.83 (6.66), Complete cases, Baseline: 34.75 (6.73),4 months: $34.89(6.84)$

BP: Mean arterial pressure ( $\mathrm{mm} \mathrm{Hg}$ ), ITTA (used in analysis), Baseline: 95.96 (11.48), 4 months: 96.64 (10.40), Complete cases,

Baseline: 95.41 (11.94), 4 months: 95.85 (10.34)

Lipids:

Total cholesterol: HDL ratio: ITTA (used in analysis, Baseline: 3.8 (0.98), 4 months: 3.69 (0.87), Complete cases, Baseline: 3.77 $(1.01)$

4 months: $3.66+/-0.88$ 
Diet: Eating habits - "Starting the conversation" scale: ITTA (used in analysis), Baseline: 2.13 (0.31), 4 months: $2.19(0.28)$ Complete cases, Baseline: 2.15 (0.3), 4 months: 2.18 (0.26) Fat intake - National Cancer Institute \% energy from fat screen: ITTA (used in analysis), Baseline: 35.21 (4.7), 4 months: 34.95 (4.93), Complete cases, Baseline: 34.90 (4.73), 4 months: 34.81 (4.95) Physical Activity: Physical activity (cals per week) - CHAMPS questionnaire, ITTA (used in analysis), Baseline: 3979 (3292) 4 months: 3241 (3221), Complete cases, Baseline: 3885 (3306), 4 months: 3098 (3107) Adherence: Medication adherence - Hill Bone Compliance scale: ITTA (used in analysis), Baseline: 3.78 (0.28), 4 months: $3.80(0.37)$,

Complete cases, Baseline: 3885 (3306), 4 months: 3098 (3107)

\section{Leu 2005}

Intervention: HbA1c: Prior to enrolment $8.5 \%$, Prelim interview $8.3 \%$, Exit interview $8.2 \%$. Difference $-0.13(0.93)$

Control:

HbA1c: Prior to enrolment 8.5\%, Prelim interview 8.2\%, Exit interview $7.9 \%$. Difference $-0.3(1.12)$

\section{$\operatorname{Lim} 2011$}

Intervention:

Blood pressure (\% hypertensive): Preliminary interview 64\% (16/25), Preliminary (stayed enrolled) 62\% (13/21), Exit interview $38 \%(8 / 21)$

Control:

Blood pressure (\% hypertensive), Preliminary interview 68\% (17/25), Preliminary (stayed enrolled) $71 \%$ (15/21), Exit interview $76 \%(16 / 21)$

\author{
I: The proportion \\ of patients who \\ achieved $\mathrm{A} 1 \mathrm{C}<$ \\ $7.0 \%$ without hypo- \\ glycaemia, the pri- \\ mary end point of \\ this study, \\ was $30.6 \%$ in the $u$ - \\ healthcare group. \\ $\mathrm{C}$ : The proportion \\ of patients that \\ achieved $\mathrm{A} 1 \mathrm{C}<$ \\ $7.0 \%$ without hypo- \\ glycaemia, the pri- \\ mary end point of \\ this study, \\ was $14.0 \%$ in the \\ control groups. \\ Intervention: \\ HbA1c \%: baseline 7.8 (1.3), 6 months 7.4 (1.0), \\ BMI: baseline 24.7 (2.4), 6 months 24.4 (2.5) \\ TC: $\mathrm{mmol} / \mathrm{L}$ baseline 4.53 (0.93), 6 months $4.45(0.88)$ \\ TG: $\mathrm{mmol} / \mathrm{L}$ baseline 1.70 (0.66), 6 months $1.57(0.64)$ \\ HDL: $\mathrm{mmol} / \mathrm{L} 1.34$ (0.31), 6 months 1.29 (0.21) \\ LDL: $\mathrm{mmol} / \mathrm{L} 2.98$ (0.72), 6 months 2.48 (0.68) \\ Weight: baseline: 64.3 (8.5), 6 months 63.5 (8.5) \\ Fasting glucose : baseline 137.3 (32.7), 6 months 124.3 \\ (29.7) \\ Postprandial glucose: baseline 250.1 (68), 6 months 210.1 \\ (49) \\ Frequency of SMBG: baseline 3.2 (3.5), 6 months 10.5 (5.1) \\ Control: \\ HbA1c \%: baseline 7.9 (0.8), 6 months 7.8 (1.0) \\ BMI: baseline 25.5 (3.5), 6 months 25.8 (3.4) \\ TC: $\mathrm{mmol} / \mathrm{L}$ baseline 4.38 (0.78), 6 months $4.51(0.78)$ \\ TG: $\mathrm{mmol} / \mathrm{L}$ baseline 1.53 (0.51), 6 months $1.47(0.79)$ \\ HDL: mmol/L 1.13 (0.28), 6 months $1.17(0.24)$ \\ LDL: mmol/L 2.84 (0.53), 6 months 2.41 (0.39) \\ Weight: baseline: 63.6 (9.9), 6 months 64.2 (9.4) \\ Fasting glucose: baseline 146.8 (48.4), 6months 152.6 \\ (58.0) \\ Postprandial glucose: baseline 259.1 (64.5), 6 months 291.1 \\ (77.9) \\ Frequency of SMBG: baseline 2.7 (4.4), 6 months 2.4 (3.3)
}


HbA1c: Pre-education GHb 1280, post education $1137 \mathrm{df} 11, \mathrm{t}$

val -2.642 tailed prob 0.023

Knowledge: pre-education knowledge score: mean 10.92 post-

education knowledge score: mean $14.33 \mathrm{df} 11$, t-value 9.03

2tailed prob 0.000

Control:

HbA1c: Pre-education GHb 1088, post education $1236 \mathrm{df}$ 15, t

val 2.702 tailed prob 0.016

Knowledge: pre-education knowledge score: mean 9.31 post-

education knowledge score: mean $13.06 \mathrm{df} 15$, t-value 5.42

2tailed prob 0.000

\begin{tabular}{ll}
\hline Lorig 2010 & HbA1c \\
& Intervention: \\
& Change in A1C: \\
& $0.009(0.852)$ \\
& Control: Change in \\
& A1C: $0.126(0.779)$
\end{tabular}

Intervention:

Health distress scale change: Treatment combined: -0.203

(1.02)

Activity limitation scale change (0-4, lower is better): 0.006

(0.923)

Self efficacy scale change (0-10, higher better): 0.245 (1.87)

Change in aerobic exercise per week in $\mathrm{min} / \mathrm{wk}: 7.04$ (156)

PHQ9 score - 0.754 (4.26)

PAM patient activation (scale $0-100$, higher is better): 5.70

(14.4)

Control:

Health distress scale change: $-0.257(0.844)$

Activity limitation scale change (0-4, lower is better): 0.034

(0.848)

Self efficacy scale change (0-10, higher better): -0.203 (1.70)

Change in aerobic exercise per week in $\mathrm{min} / \mathrm{wk}$ :-1.97 (130)

PHQ9 score -0.836 (3.82)

PAMpatient activation change (scale $0-100$, higher better): 3.63

(14.4)

\section{Quinn 2008}

Intervention:

HbA1c: Baseline 9.51, 3 months: 7.48 P value 0.04

Patient confident about DM control (self-reported): $100 \%$ at 3 months, no baseline

Knowledge: Improved knowledge of food choices (self-reported): $90.91 \%$ at 3 months, no baseline

Diet: Diabetes self-care: SDSCA scores - diet: baseline 3.15, 3

months 5.5

Exercise: Diabetes self-care: SDSCA scores - 3. Exercise baseline

2.08, 3 months 2.92

Adherence: Diabetes self-care: SDSCA scores - 2. Medications: baseline 5.923 months 6.64

Depression: New diagnosis of depression at 3 months: $9.09 \%$

Medication intensified: $84.62 \%$

Medication errors identified: $53.38 \%$

Control:

HbA1c: Baseline(means) 9.05, 3 months: 8.37 P value 0.04

Patient confident about DM control (self-reported) : $75 \%$ at 3

months, no baseline

Knowledge: Improved knowledge of food choices (self-report-

ed): $50 \%$ at 3 months, no baseline

Diet: Diabetes self-care: SDSCA scores - diet: baseline 3.15, 3 months 3.86

Exercise: Diabetes self-care: SDSCA scores - 3. Exercise baseline

$1.23,3$ months 1.57

Adherence: Diabetes self-care: SDSCA scores - 2. Medications:

baseline 6.3, 3 months 6.75

Depression: New diagnosis of depression at 3 months: $20 \%$ 


\section{Quinn 2011}

\section{Intervention:} HbA1c: 12 months: $\mathrm{n}=217.7(1.0)$ change $-1.6(-2.3$ to $-1.0)$ Control: HbA1c: 12 months: $\mathrm{n}=518.5(1.8)$ change $-0.7(-1.1$ to $-0.3)$

\section{Intervention}

HbA1c: Baseline 9.3 (1.8) 3 months: $n=13,7.6$ (1.2) 6 months: $n$ $=157.6$ (1.1) 9 months: $\mathrm{n}=167.6$ (0.9)

HRQOL: Diabetes Distress scale baseline $n=232.7(0.9), 12$ months $n=202.6$ (0.9). Change $-0.1(-0.4$ to 0.3$)$

Blood Pressure: systolic: baseline $n=23130$ (18), 12 months $n$ $=21134$ (25), change +4 (-4 to 11), diastolic: baseline $n=2379$ (11),

12 months $n=2182$ (11), change +2 ( -2 to 7$)$

Change in lipids: TC: baseline $n=23,4.69(0.91), 12$ months $n=$ $16,3.91(0.88)$ Change -0.62 (-1.11 to -0.13$)$

TG: baseline $n=23,1.94$ (1.13), 12 months $n=16,1.28(0.47)$

Change -0.60 (-1.24 to 0.05$)$

HDL: baseline $n=23,1.14(0.28), 12$ months $n=161.09(0.23)$

Change $+0(-0.10$ to 0.08$)$

LDL: baseline $n=23,2.67(0.75), 12$ months $n=192.44(0.83)$

Change -0.21 (-0.54 to 0.13$)$

Depression: PHQ -9 score Baseline $\mathrm{n}=23$ 5.2(4.8), 12 months: $\mathrm{n}$

$=214.6(5)$ change : -0.6 ( -2.7 to 1.4$)$

Other - Diabetes symptom inventory: Diabetes symptom inventory baseline $n=2216.4$ (5.7), 12 months $n=2115.5$ (4.5) change: -2.8 (-7.7 to 2.0$)$

Control:

HbA1c: Baseline 9.2 (1.7), 3 months: $\mathrm{n}=30,8.2$ (1.2) 6 months: $\mathrm{n}$ $=278.6$ (2.0) 9 months: $\mathrm{n}=438.5$ (1.8)

HRQOL: Diabetes Distress scale baseline $2.4(0.9), 12$ months $n$

$=462.3$ (0.9). Change $-0.1(-0.4$ to 0.1$)$

Blood Pressure: systolic: baseline $n=56130$ (22), 12 months $n=$ 45133 (20), change +2 (-3 to 7), diastolic baseline $n=5678$ (12) 12 months $n=4579$ (13), change +1 ( -2 to 4$)$

Change in lipids: TC: baseline $n=56,4.72(1.32), 12$ months $n=$ 44, 4.35 (1.04) Change -0.28 ( -0.57 to 0.03 )

TG: baseline $n=56,2.09$ (1.89), 12 months $n=44,1.91(1.40)$

Change -0.26 (-0.66 to 0.14$)$

HDL: baseline $n=56,1.14(0.28), 12$ months $n=441.17(0.31)$

Change +0.03 ( -0.03 to 0.08$)$

LDL: baseline $n=51,2.64$ (0.93), 12 months $n=422.36(0.89)$

Change -0.16 ( -0.39 to 0.08$)$

Depression: PHQ -9 score Baseline $\mathrm{n}=56$ 4.7(5.6) 12 month: $\mathrm{n}=$ 44 3.6(4.1) change : -1.1 (-3.2 to 3.0),

Other - Diabetes symptom inventory baseline: Baseline 15.6

(5.6), 12 months $n=4614.6$ (4.8) change: -2.3 ( -5.5 to 0.9 )

\section{Smith 2000}

Intervention:

Quality of life scale raw mean : 17.18 at 5 months, was adjusted for 7 covariates but no differences between control/ intervention groups after adjustment. Higher scores indicate better perceived QoL. NB/ no statistical measures of whether differences are significant are given in the text.

2/15 participants reported $\mathrm{HbA1Cs}$ before and after the intervention, there was an average decrease of $1.6 \%$ in the noncomputer group, however nothing of significance can be said about these data. NB/ no statistical measures of whether differences are significant are given in the text.

Personal resource questionnaire: raw mean score at 5 months $=121.76$, was adjusted for 7 covariates but no differences between control/ intervention groups after adjustment. Higher 
PRQ scores indicate higher levels of social support. NB/ no statistical measures of whether differences are significant are given in the text.

Psychological adjustment to illness scale: raw mean score at 5 months $=77.79$, was adjusted for 7 covariates but no differences between control/ intervention groups after adjustment. Lower PAIS scores show better adjustment to illness.

NB/ no statistical measures of whether differences are significant are given in the text.

Control:

Quality of life scale raw mean: 17.90 at 5 months, was adjusted for 7 covariates but no differences between control/ intervention groups after adjustment. Higher scores indicate better perceived QoL.

$3 / 15$ participants reported $\mathrm{HbA} 1 \mathrm{Cs}$ before and after the intervention, there was an average increase of $1 \%$ in the non-computer group, however nothing of significance can be said about these data. NB/ no statistical measures of whether differences are significant are given in the text.

Personal resource questionnaire : raw mean score at 5 months $=128.53$, was adjusted for 7 covariates but no differences between control/ intervention groups after adjustment. Higher PRQ scores indicate higher levels of social support. NB/ no statistical measures of whether differences are significant are given in the text.

Psychological adjustment to illness: scale raw mean score at 5 months $=80.24$, was adjusted for 7 covariates but no differences between control/ intervention groups after adjustment. Lower PAIS scores show better adjustment to illness. NB/ no statistical measures of whether differences are significant are given in the text.

\begin{tabular}{ll}
\hline Wise 1986 & Knowledge Index: \\
& Intervention: Mean \\
& $+/-$ SE, baseline 60 \\
& $+/-3$, final $73+/-2$ \\
& Control: no control \\
& group for knowl- \\
& edge \\
& HbA1c: Interven- \\
& tion: Mean +/- SE, \\
& HbA1c baseline \\
& $8.7 \%+/-0.7$, final \\
& $7.9 \%+/-0.6$ \\
Control: Mean $\%$, \\
HbA1c baseline \\
8.7\%, final 8.5\%
\end{tabular}

Intervention: Mean =/- SE

HbA1c baseline 8.7+/- 0.7, final 7.9+/- 0.6

Control: Mean $=/-\mathrm{SE}$

HbA1c baseline 8.7, final 8.5\%+/- 0.57 (calculated from graph)
Initial outlay $\$ 5000$ transferred to system costing $\$ 800$.

\section{Yoo 2009}

\author{
Intervention: \\ HbA1c: baseline: 7.6 (0.9), 3 months: $7.1(0.8)$ \\ BMI: baseline: 25.6 (3.5), 3 months: 25.1 (3.5) \\ Total cholesterol: base 4.6 (0.8), 3 months 4.1 (0.7) \\ HDL: baseline $1.2(0.3), 3$ months $1.3(0.3)$ \\ LDL: baseline $2.6(0.7), 3$ months $2.2(0.6)$ \\ TG: baseline $1.46[1.1,2.1], 3$ months $1.24[0.8,1.8]$ \\ Weight: baseline 66.4 (12.5), 3 months 65.3 (12.7) $\mathrm{P}=0.002$ \\ Waist Circumference: baseline 89.5 (9.7), 3 months 86.8 (9.8) P \\ $<0.001$ \\ Control: \\ HbA1c: baseline: 7.4 (0.9), 3 months: 7.6 (1.0)
}
Participants in the intervention group sent blood glucose recordings 1.840 .31 times per day (com- pliance rate 92.2 $15.4 \%)$ and blood pressure 1.720 .32 times per day (compliance rate $86.016 .2 \%)$. Body weight mea- 
BMI: baseline: 25.5 (3.3), 3 months: 25 (3.3)

Total cholesterol: base 4.5 (0.9), 3 months $4.5(0.8)$

HDL: baseline $1.2(0.3), 3$ months $1.3(0.3)$

LDL: baseline $2.4(0.7), 3$ months $2.3(0.7)$

TG: baseline 1.51 [1.1, 2.5], 3 months $1.59[1.2,2.4]$

Weight: baseline 67.7 (10.8), 3 months $66.4(10.4) \mathrm{P}=0.004$

Waist Circumference: baseline 91.3 (7.5), 3 months 89.1 (7.6) P

$=0.001$ surements were

sent

0.870 .20 times per

day (compliance

rate $87.420 .1 \%)$.

\section{Zhou 2003}

Intervention:

HbA1c: Baseline: 8.66 (1.47), 8 weeks: 8.03 (1.09)

BMI: Baseline: 24.04 (3.10), 8 weeks: 23.12 (5.05)

Fasting blood glucose mmol/L: baseline: 7.72 (1.92), 8 weeks:

$6.31(1.00)$

2 hour post-prandial blood glucose $\mathrm{mmol} / \mathrm{L}$ : baseline: 10.436

(2.99), 8 weeks: 7.60 (1.68)

Total cholesterol mmol/L: Baseline: 5.01 (0.99), 8 weeks: 5.07

(1.01)

Triglycerides mmol/L: Baseline: 1.36 [0.99 - 1.87], 8 weeks: 1.28

[0.94- 1.67]

HDL cholesterol mmol/L: Baseline: 1.55 (0.40), 8 weeks: 1.509

(0.34)

LDL cholesterol mmol/L: Baseline: 3.06 (0.87), 8 weeks: 3.06

(0.80)

Urimary albumin excretion ( $\mathrm{mg} / \mathrm{gr} \mathrm{Cr}$ ): Baseline: 10.80 [6.60-

26.09], 8 weeks: 9.80 [5.61- 21.03]

Control:

HbA1c: Baseline: 8.97 (1.76), 8 weeks: 8.77 (1.74)

BMI: Baseline: 24.51 (2.82), 8 weeks: 24.46 (2.77)

Fasting blood glucose mmol/L: baseline: 7.80 (1.33), 8 weeks:

7.49 (1.34)

2 hour post-prandial blood glucose $\mathrm{mmol} / \mathrm{L}$ : baseline: 10.46

(1.84), 8 weeks: 9.84 (2.41)

Total cholesterol mmol/L: Baseline: 5.26 (0.49), 8 weeks: 5.54

(1.02)

Triglycerides mmol/L: Baseline: 1.48 [1.06 - 1.96], 8 weeks: 1.52

[1.15- 2.18]

HDL cholesterol mmol/L: Baseline: 1.46 (0.31), 8 weeks: 1.50

(0.32)

LDL cholesterol mmol/L: Baseline: 3.20 (0.87), 8 weeks: 3.43

(0.91)

Urimary albumin excretion ( $\mathrm{mg} / \mathrm{gr} \mathrm{Cr}$ ): Baseline: 14.50

[6.85-41.80], 8 weeks: 14.15 [6.60-30.35]

\section{Footnotes}

a,bAs stated in the publication

cNot stated as primary or secondary endpoint(s) in the publication

BMI: body mass index; C: control; DM: diabetes mellitus; GHb: glycated haemoglobin; HDL: high-density lipoprotein; HRQOL: healthrelated quality of life; I: intervention; LDL: low-density lipoprotein; MET-min: metabolic equivalent minutes; PHQ-9: patient health questionnaire; SDSCA: Summary of Diabetes Self-Care Activities; SD: standard error; SMBG: self-monitoring of blood glucose; TC total cholesterol; TG Triglycerides 


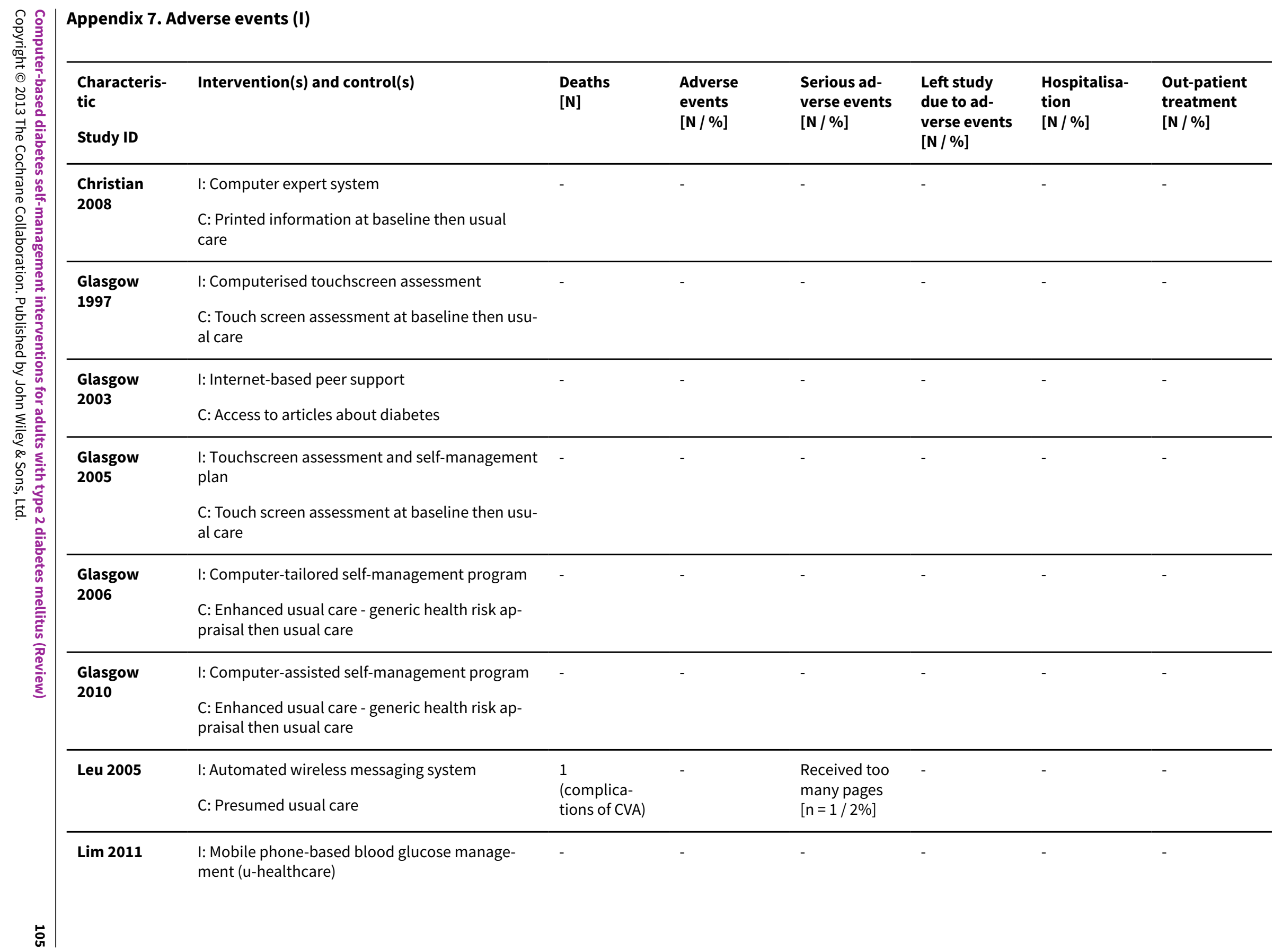




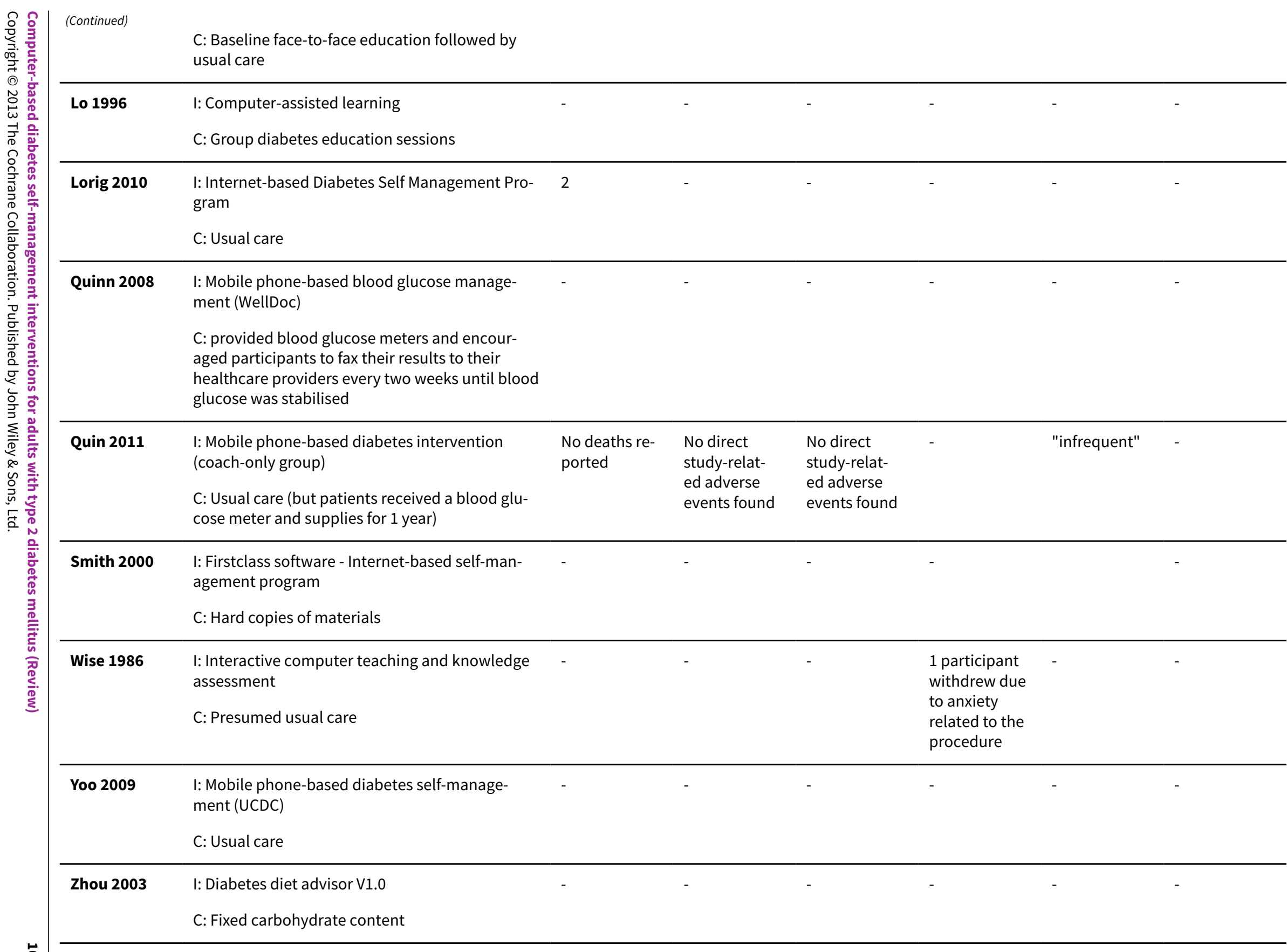




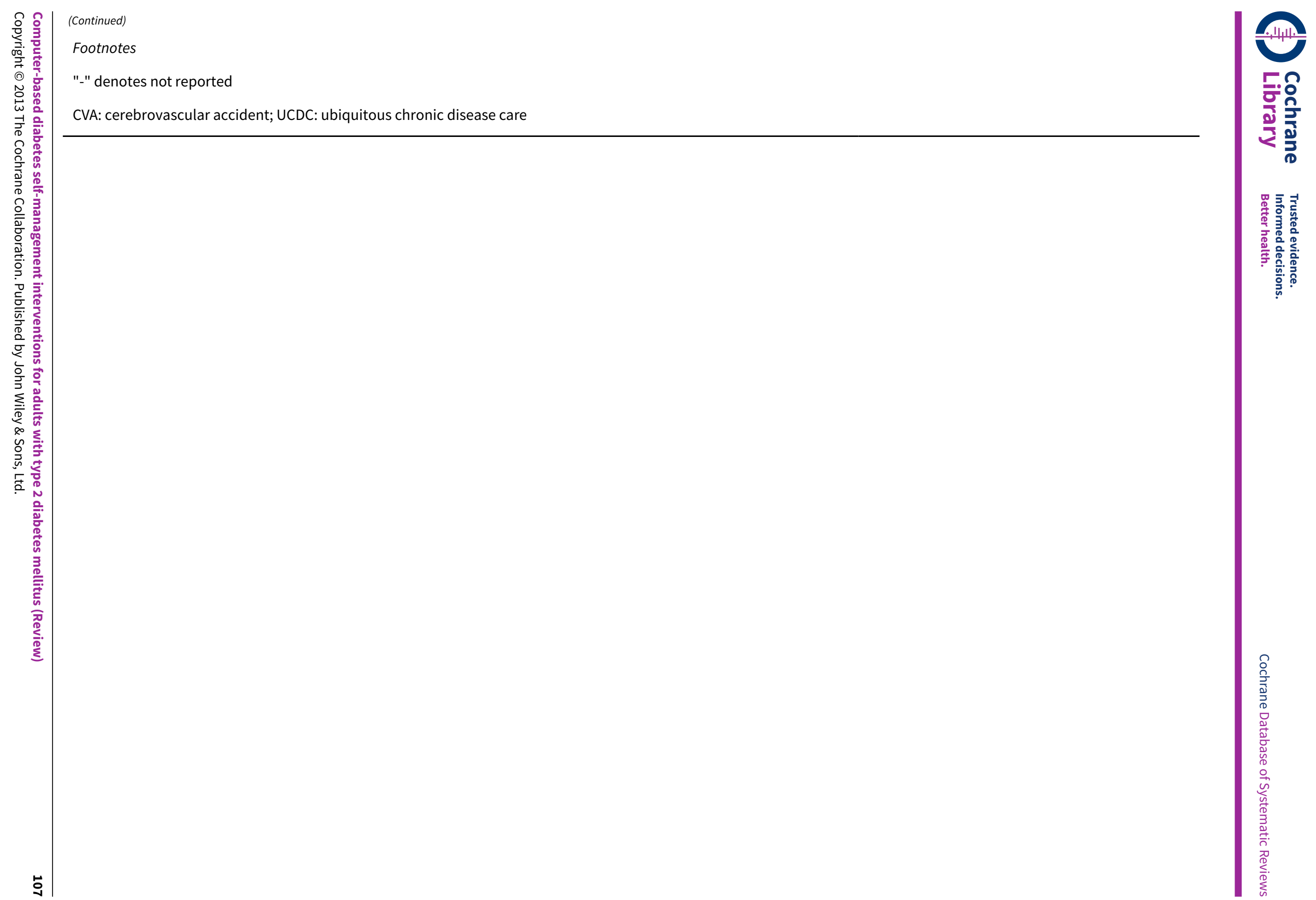


Appendix 8. Adverse events (II)

\begin{tabular}{|c|c|c|c|c|c|c|}
\hline $\begin{array}{l}\text { Character- } \\
\text { istic } \\
\text { Study ID }\end{array}$ & Intervention(s) and control(s) & $\begin{array}{l}\text { Hypogly- } \\
\text { caemic } \\
\text { episodes } \\
{[\mathrm{N} / \%]}\end{array}$ & $\begin{array}{l}\text { Severe } \\
\text { hypogly- } \\
\text { caemic } \\
\text { episodes } \\
{[\mathrm{N} / \% \text { ] }}\end{array}$ & $\begin{array}{l}\text { Definition } \\
\text { of severe / } \\
\text { serious } \\
\text { hypogly- } \\
\text { caemia }\end{array}$ & $\begin{array}{l}\text { Nocturnal } \\
\text { hypogly- } \\
\text { caemic } \\
\text { episodes } \\
\text { [N / \%] }\end{array}$ & $\begin{array}{l}\text { Symptoms } \\
\text { [N / \%] }\end{array}$ \\
\hline $\begin{array}{l}\text { Christian } \\
2008\end{array}$ & $\begin{array}{l}\text { I: Computer expert system } \\
\text { C: Printed information at baseline then } \\
\text { usual care }\end{array}$ & - & - & - & - & - \\
\hline $\begin{array}{l}\text { Glasgow } \\
1997\end{array}$ & $\begin{array}{l}\text { I: Computerised touchscreen assessment } \\
\text { C: Touch screen assessment at baseline } \\
\text { then usual care }\end{array}$ & - & - & - & - & - \\
\hline $\begin{array}{l}\text { Glasgow } \\
2003\end{array}$ & $\begin{array}{l}\text { I: Internet-based peer support } \\
\text { C: Access to articles about diabetes }\end{array}$ & - & - & - & - & - \\
\hline $\begin{array}{l}\text { Glasgow } \\
2005\end{array}$ & $\begin{array}{l}\text { I: Touchscreen assessment and self-man- } \\
\text { agement plan } \\
\text { C: Touch screen assessment at baseline } \\
\text { then usual care }\end{array}$ & - & - & - & - & - \\
\hline $\begin{array}{l}\text { Glasgow } \\
2006\end{array}$ & $\begin{array}{l}\text { I: Computer-tailored self-management } \\
\text { program } \\
\text { C: Enhanced usual care - generic health } \\
\text { risk appraisal then usual care }\end{array}$ & - & - & - & - & - \\
\hline $\begin{array}{l}\text { Glasgow } \\
2010\end{array}$ & $\begin{array}{l}\text { I: Computer-assisted self-management } \\
\text { program } \\
\text { C: Enhanced usual care - generic health } \\
\text { risk appraisal then usual care }\end{array}$ & - & - & - & - & - \\
\hline
\end{tabular}

Leu 2005 I: Automated wireless messaging system

C: Presumed usual care

\begin{tabular}{|c|c|c|c|c|c|c|}
\hline $\operatorname{Lim} 2011^{a}$ & $\begin{array}{l}\text { I: Mobile phone-based blood glucose man- } \\
\text { agement (u-healthcare) } \\
\text { C: Baseline face-to-face education followed } \\
\text { by usual care }\end{array}$ & $\begin{array}{l}\text { "The pro- } \\
\text { portion of } \\
\text { patients } \\
\text { experienc- } \\
\text { ing minor } \\
\text { hypogly- } \\
\text { caemia } \\
\text { seemed to } \\
\text { be higher } \\
\text { in u-health- } \\
\text { care group } \\
\text { ( } 32.2 \%) \\
\text { than in } \\
\text { the con- } \\
\text { trol groups } \\
(21.8 \%) \text { but }\end{array}$ & $\begin{array}{l}\text { "Major and } \\
\text { nocturnal } \\
\text { hypogly- } \\
\text { caemia } \\
\text { was small- } \\
\text { er in the } \\
\text { uhealth- } \\
\text { care group } \\
\text { than in the } \\
\text { control } \\
\text { group (P< } \\
0.05) "\end{array}$ & - & $\begin{array}{l}\text { "Major and } \\
\text { nocturnal } \\
\text { hypogly- } \\
\text { caemia } \\
\text { was small- } \\
\text { er in the } \\
\text { uhealth- } \\
\text { care group } \\
\text { than in the } \\
\text { control } \\
\text { group (P< } \\
0.05) "\end{array}$ & - \\
\hline
\end{tabular}


statistical

significance

was not

found.

\section{Lo 1996 I: Computer-assisted learning \\ C: Group diabetes education sessions}

Lorig 2010 I: Internet-based Diabetes Self Management Program

C: Usual care

\begin{tabular}{ll}
\hline $\begin{array}{l}\text { Quinn } \\
\mathbf{2 0 0 8}\end{array}$ & $\begin{array}{l}\text { I: Mobile phone-based blood glucose man- } \\
\text { agement (WellDoc) }\end{array}$ \\
& C: provided blood glucose meters and en- \\
couraged participants to fax their results to \\
their healthcare providers every two weeks \\
until blood glucose was stabilised
\end{tabular}

\begin{tabular}{ll}
\hline Quin 2011 & $\begin{array}{l}\text { I: Mobile phone-based diabetes interven- } \\
\text { tion (coach-only group) }\end{array}$ \\
& $\begin{array}{l}\text { "Infre- } \\
\text { quent" }\end{array}$ \\
& $\begin{array}{l}\text { C: Usual care (but patients received a } \\
\text { blood glucose meter and supplies for } 1 \\
\text { year) }\end{array}$
\end{tabular}

Smith 2000 I: Firstclass software - Internet-based selfmanagement program

C: Hard copies of materials

Wise 1986 I: Interactive computer teaching and knowledge assessment

C: Presumed usual care

Yoo 2009 I: Mobile phone-based diabetes self-management (UCDC)

C: Usual care

\section{Zhou 2003 I: Diabetes diet advisor V1.0 \\ C: Fixed carbohydrate content}

\section{Footnotes \\ "-" denotes not reported}

aDefinition of hypoglycaemic episodes: minor hypoglycaemia: symptoms coexisting with capillary blood glucose levels $<3.5 \mathrm{mmol} /$ $\mathrm{L}(63 \mathrm{mg} / \mathrm{dL})$; major hypoglycaemia: blood glucose levels $<2.8 \mathrm{mmol} / \mathrm{L}(50 \mathrm{mg} / \mathrm{dL})$ and an episode requiring medical intervention or exhibiting markedly depressed level of consciousness or seizure; nocturnal hypoglycaemia: hypoglycaemic event occurring while asleep

UCDC: ubiquitous chronic disease care 


\section{Appendix 9. Behaviour change techniques used}

\begin{tabular}{lll}
\hline $\begin{array}{l}\text { Characteristic } \\
\text { Study ID }\end{array}$ & Intervention & Control \\
\hline Christian 2008 & 1 Provide information on consequences of behaviour in general & $\begin{array}{l}1 \text { Provide information } \\
\text { on consequences of be- } \\
\text { haviour in general }\end{array}$ \\
& 5 Goal setting (behaviour) & \\
& 6 Goal setting (outcome) \\
& 8 Barrier identification/Problem solving \\
& 10 Prompt review of behavioural goals \\
& 38 Motivational interviewing
\end{tabular}

\begin{tabular}{ll}
\hline Glasgow 1997 & 5 Goal setting (behaviour) \\
& 6 Goal setting (outcome) \\
& 8 Barrier identification/Problem solving \\
& 10 Prompt review of behavioural goals \\
& 27 Use of follow up prompts
\end{tabular}

\begin{tabular}{|c|c|c|}
\hline Glasgow 2003 & $\begin{array}{l}\text { Peer support intervention: } \\
1 \text { Provide information on consequences of behaviour in general } \\
28 \text { Facilitate social comparison }\end{array}$ & $\begin{array}{l}1 \text { Provide information } \\
\text { on consequences of be- } \\
\text { haviour in general } \\
5 \text { Goal setting (behav- } \\
\text { iour) }\end{array}$ \\
\hline Glasgow 2005 & $\begin{array}{l}5 \text { Goal setting (behaviour) } \\
8 \text { Barrier identification/ Problem solving } \\
27 \text { Use follow-up prompts }\end{array}$ & $\begin{array}{l}1 \text { Provide information } \\
\text { on consequences of be- } \\
\text { haviour in general }\end{array}$ \\
\hline Glasgow 2006 & $\begin{array}{l}5 \text { Goal setting (behaviour) } \\
8 \text { Barrier identification/Problem solving } \\
10 \text { Prompt review of behavioural goals } \\
27 \text { Use follow-up prompts } \\
38 \text { Motivational interviewing }\end{array}$ & $\begin{array}{l}1 \text { Provide information } \\
\text { on consequences of be- } \\
\text { haviour in general }\end{array}$ \\
\hline
\end{tabular}

\section{Glasgow 2010}

1 Provide information on consequences of behaviour in general

1 Provide information

5 Goal setting (behaviour) on consequences of be-

8 Barrier identification/Problem solving

19 Provide feedback on performance

\begin{tabular}{lll}
\hline Leu 2005 & 23 Teach to use prompts/cues & Not stated \\
\hline Lim 2011 & 16 Prompt self-monitoring of behaviour & Not stated
\end{tabular}


19 Provide feedback on performance

23 Teach to use prompts or cues

Lo 1996 Provide information on consequences of behaviour in general

1 Provide information on consequences of behaviour in general

Lorig $2010 \quad$ Provide information on consequences of behaviour in general
3 Provide information about others' approval
4 Provide normative information about others' behaviour
8 Barrier identification/Problem solving
17 Prompt self-monitoring of behavioural outcome
37 Emotional control training

\begin{tabular}{|c|c|c|}
\hline \multirow[t]{2}{*}{ Quinn 2008} & $\begin{array}{l}17 \text { Prompt self-monitoring of behavioural outcome } \\
19 \text { Provide feedback on performance }\end{array}$ & \multirow[t]{2}{*}{$\begin{array}{l}17 \text { Prompt self-monitor- } \\
\text { ing of behavioural out- } \\
\text { come }\end{array}$} \\
\hline & 20 Provide information on where and when to perform the behaviour & \\
\hline \multirow[t]{2}{*}{ Quinn 2011} & 17 Prompt self-monitoring of behavioural outcome & Not stated \\
\hline & 19 Provide feedback on performance & \\
\hline Smith 2000 & $\begin{array}{l}1 \text { Provide information on consequences of behaviour in general } \\
29 \text { Plan social support/social change }\end{array}$ & $\begin{array}{l}1 \text { Provide information } \\
\text { on consequences of be- } \\
\text { haviour in general }\end{array}$ \\
\hline Wise 1986 & 1 Provide information on consequences of behaviour in general & Not stated \\
\hline \multirow[t]{8}{*}{ Yoo 2009} & 1 Provide information on consequences of behaviour in general & Not stated \\
\hline & 2 Provide information on consequences of behaviour to the individual & \\
\hline & 16 Prompt self-monitoring of behaviour & \\
\hline & 17 Prompt self-monitoring of behavioural outcome & \\
\hline & 19 Provide feedback on performance & \\
\hline & 20 Provide information on where and when to perform the behaviour & \\
\hline & 23 Teach to use prompts or cues & \\
\hline & 32 Fear arousal & \\
\hline Zhou 2003 & 7 Action planning & $\begin{array}{l}5 \text { Goal setting (behav- } \\
\text { iour) }\end{array}$ \\
\hline
\end{tabular}

Footnotes

Numbers correspond to additional Table 1 ('taxonomy of behaviour change techniques')

\section{Appendix 10. Behaviour change techniques grouped by effect on Hba1c}


Behaviour change technique (BCT)

\begin{tabular}{ll}
$\begin{array}{l}\text { Number of interven- } \\
\text { tions }\end{array}$ & $\begin{array}{l}\text { Number of interven- } \\
\text { tions }\end{array}$ \\
$\begin{array}{l}\text { using BCT with a sig- } \\
\text { nificant }\end{array}$ & using BCT with no \\
impact on HbA1c & impact on HbAlc \\
\hline
\end{tabular}

\begin{tabular}{lll}
\hline Prompt self-monitoring of behavioural outcome & 4 \\
\hline Provide feedback on performance & 4 & 1 \\
\hline Provide information on consequences of behaviour & 2 & 5 \\
in general & & \\
\hline
\end{tabular}

Prompt self-monitoring of behaviour

2

Provide information on where and when to perform

the behaviour

\begin{tabular}{|c|c|c|}
\hline Teach to use prompts or cues & 2 & 1 \\
\hline $\begin{array}{l}\text { Provide information on consequences of behaviour } \\
\text { to the individual }\end{array}$ & 1 & \\
\hline Provide information about others' approval & 1 & \\
\hline Provide normative information about others' behaviour & 1 & \\
\hline Fear arousal & 1 & \\
\hline Emotional control training & 1 & \\
\hline Barrier identification / problem solving & 1 & 5 \\
\hline Facilitate social comparison & & 1 \\
\hline Goal setting (outcome) & & 2 \\
\hline Motivational interviewing & & 2 \\
\hline Prompt review of behavioural goals & & 3 \\
\hline Use of follow up prompts & & 3 \\
\hline Goal setting (behaviour) & & 5 \\
\hline
\end{tabular}

\section{Footnotes}

HbA1c: glycosylated haemoglobin A1c

\section{Appendix 11. Behaviour change techniques used by mobile phone interventions}




\begin{tabular}{ll}
\hline Study: & Behaviour change techniques used \\
\hline Lim 2011 & $\begin{array}{l}\text { Prompt self-monitoring of behaviour } \\
\text { Provide feedback on performance } \\
\text { Teach to use prompts or cues }\end{array}$ \\
\hline Quin $\mathbf{2 0 1 1}$ & Prompt self-monitoring of behavioural outcome \\
& Provide feedback on performance \\
& Provide information on where and when to perform the behaviour \\
\hline Yoo $\mathbf{2 0 0 9}$ & Provide information on consequences of behaviour in general \\
& Provide information on consequences of behaviour to the individual \\
& Prompt self-monitoring of behaviour \\
& Prompt self-monitoring of behavioural outcome \\
& Provide feedback on performance \\
Provide information on where and when to perform the behaviour & Teach to use prompts or cues \\
& Fear arousal \\
\hline
\end{tabular}

\section{CONTRIBUTIONS OF AUTHORS}

Kingshuk Pal (KP): protocol development, abstract screening, paper screening, data extraction, checking data extraction, and writing draft paper

Sophie Eastwood (SE): abstract screening, paper screening, data extraction, checking data extraction, reviewing drafts and the final manuscript

Susan Michie (SM): commenting on drafts, contributing to decisions in steering group meetings on study inclusion and analysis of data, and reviewing the final manuscript

Andrew Farmer (AF): commenting on drafts, contributing to decisions in steering group meetings on study inclusion and analysis of data, and reviewing the final manuscript

Maria Barnard (MB): commenting on drafts, contributing to decisions in steering group meetings on study inclusion and analysis of data, and reviewing the final manuscript

Richard Peacock (RP): commenting on drafts, contributing to decisions in steering group meetings on study inclusion and analysis of data, and reviewing the final manuscript

Bindie Wood (BW): commenting on drafts, contributing to decisions in steering group meetings on study inclusion and analysis of data, and reviewing the final manuscript

Joni Inniss (JI): commenting on drafts, contributing to decisions in steering group meetings on study inclusion and analysis of data, and reviewing the final manuscript

Elizabeth Murray (EM): commenting on drafts, checking data extraction, contributing to decisions in steering group meetings on study inclusion and analysis of data, and reviewing the final manuscript

\section{DECLARATIONS OF INTEREST}

None known.

\section{SOURCES OF SUPPORT}

\section{Internal sources}

- University College London, UK.

University providing support for the research staff and facilities 


\section{External sources}

- Camden Primary Care Trust, UK.

Contributed to the salaries of authors KP and SE

- National Institute of Healthcare Research, UK.

The NIHR school of primary care research has kindly provided a grant to support the costs of doing this review

\section{DIFFERENCES BETWEEN PROTOCOLANDREVIEW}

During the protocol stage there was some initial discussions regarding studies with mixed populations of type 1 and type 2 diabetes. As no decision had been reached at the protocol stage, the protocol stated all studies with mixed populations would be included. A final decision was reached in the steering group after the protocol was published and it was decided that studies where a majority (i.e. greater than $50 \%$ ) of participants had type 2 diabetes would be included. It was felt that populations of people with type 1 and type 2 diabetes are quite different and interventions for the two should not be combined if at all possible. Where not possible, it was decided that choosing studies with cut offs of either $60 \%, 70 \%, 80 \%$ or $90 \%$ of participants who had type 2 diabetes would be arbitrary so a simpler criteria of including studies where the majority of patients had type 2 diabetes was felt to be a simple and practical solution that would not bias the review process. Only two studies were excluded due to mixed populations (Laffel 2007; Turnin 1992) and both of these had 70\% or more participants with type 1 diabetes.

When looking at different settings, the distinction between primary care, outpatient or community setting could not be meaningfully applied to self-management interventions. It was more meaningful to divide the interventions settings into clinic-based (touch screen or other clinic computer), home computer-based and mobile phone interventions. This was used as a basis for a subgroup analysis.

\section{N DEX TERMS}

\section{Medical Subject Headings (MeSH)}

*Internet; Diabetes Mellitus, Type 2 [blood] [therapy]; Glycated Hemoglobin [metabolism]; Health Status; Quality of Life; Randomized Controlled Trials as Topic; Self Care [*methods]; Therapy, Computer-Assisted [ ${ }^{*}$ methods]

\section{MeSH check words}

Adult; Aged; Humans; Middle Aged 